\title{
STUDIES ON MOUNTAIN VEGETATION, PLANT DIVERSITY, FIRE AND FOREST LINE DYNAMICS OF THE SOUTHEASTERN and Central Ecuadorian Andes during the Late QUATERNARY
}

\author{
Dissertation \\ submitted \\ at the Georg August University Göttingen, \\ Faculty of Biology \\ for the degree "Doctor of Philosophy (PhD)" \\ in the Georg-August-University School of Science (GAUSS) Program \\ by \\ Bachelor \\ Andrea Soledad Villota Villafuerte \\ from Ecuador
}

Göttingen, September 2014 
Supervisor:

Co-Supervisor: Date of examination:
Prof. Dr. Hermann Behling

Prof. Dr. Markus Hauck

11.09.2014 


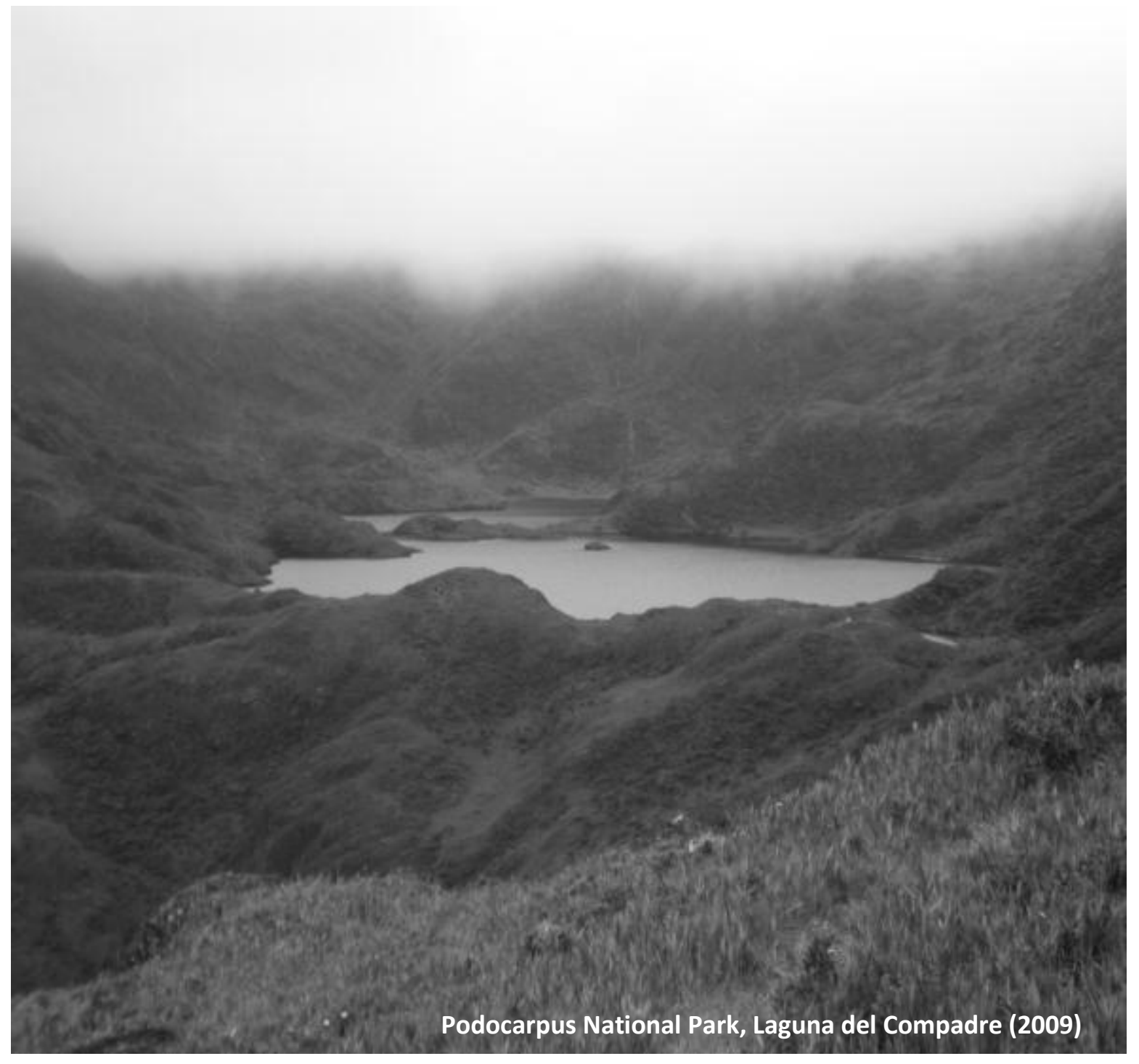

Dedicada a: Mis Padres y Hermanos 


\section{Contenido}

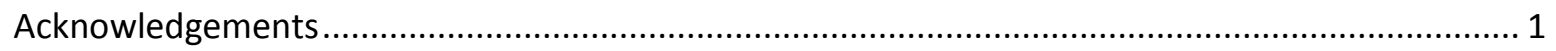

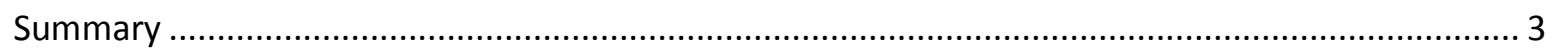

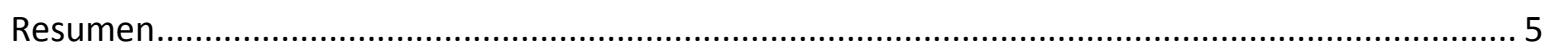

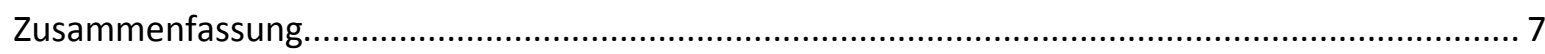

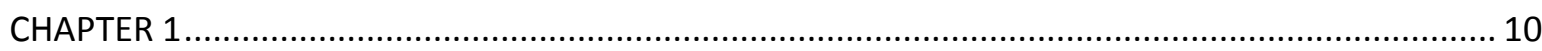

5.1 General context: scientific research of a mega-diverse ecosystem, the Ecuadorian

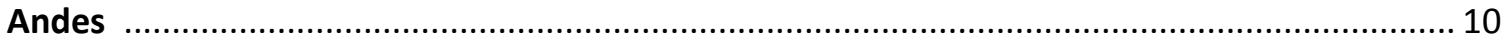

5.2 Palynological and palaeoecological research in the northern tropical Andes .............. 11

5.2.1 Previous research of palaeoecological research in the Ecuadorian Andes ........... 11

5.2.2 Reconstruction of the vegetation and climate history since the late Pleistocene. 13

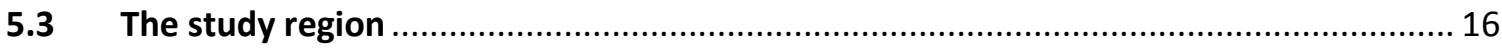

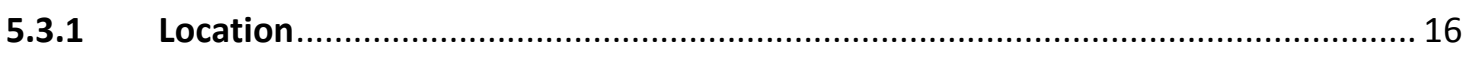

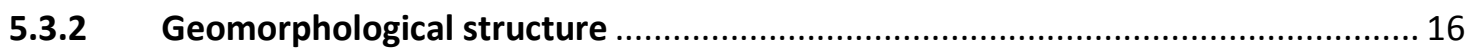

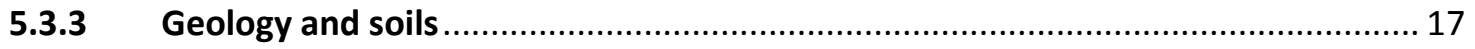

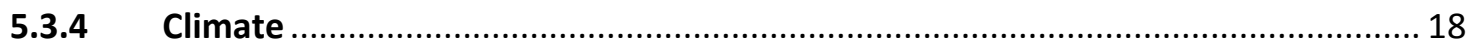

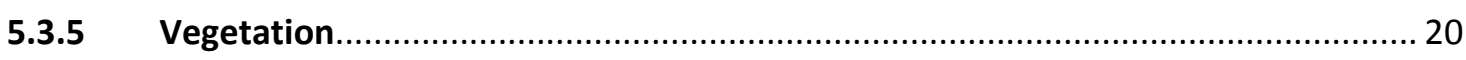

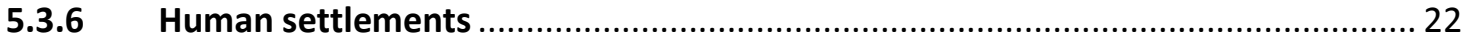

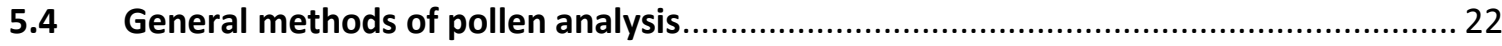

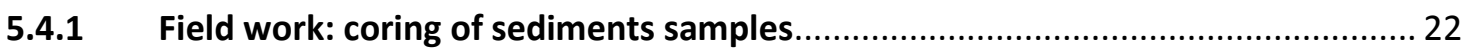

5.4.2 Laboratory work: processing of sediments samples ......................................... 23

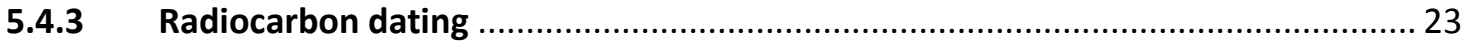

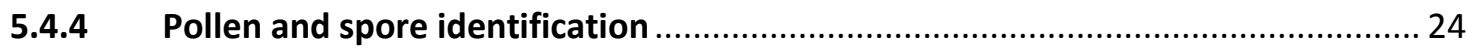

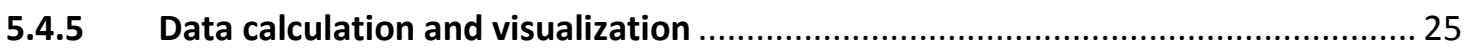

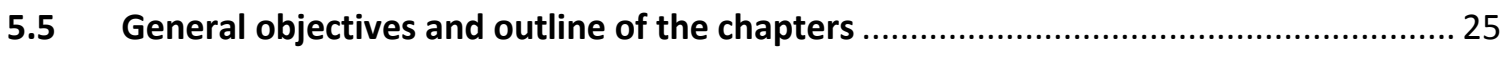

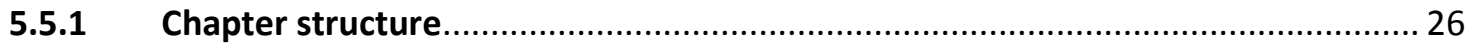

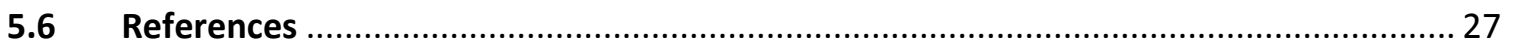

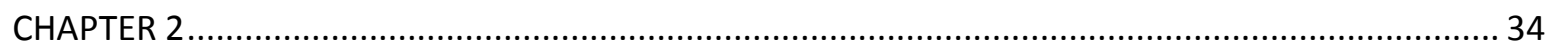


Late Quaternary vegetation, climate, and fire dynamics: human impact and evidence of past Polylepis populations in the northern Andean Depression inferred from the El Cristal record in

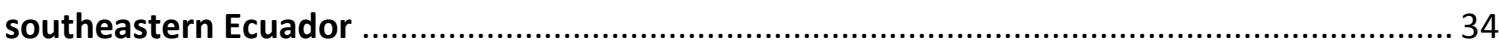

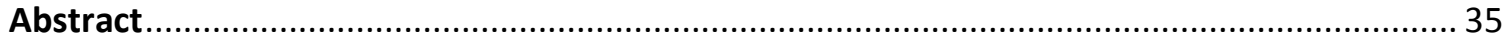

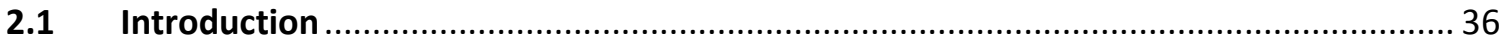

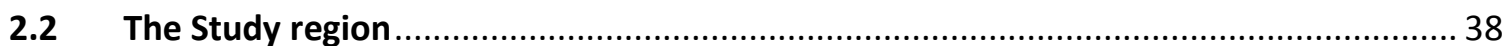

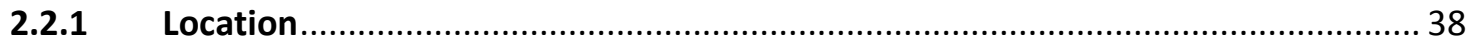

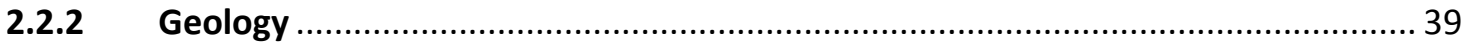

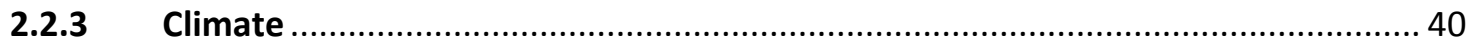

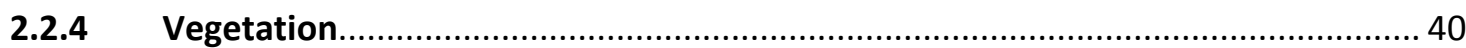

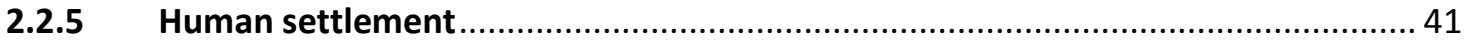

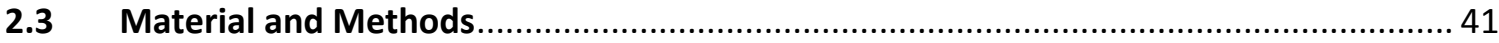

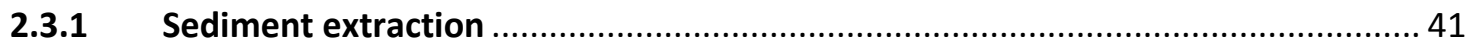

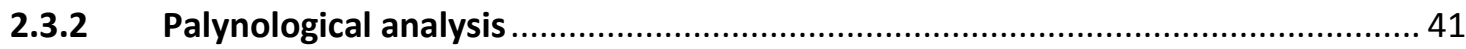

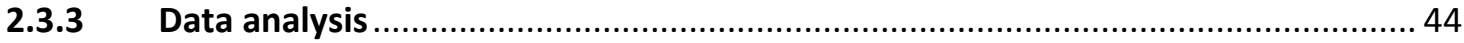

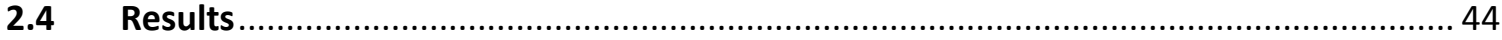

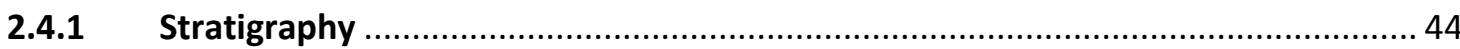

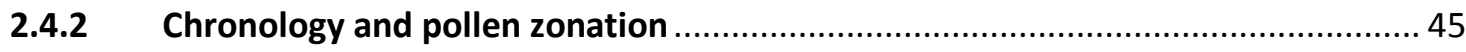

2.4.3 Description of the pollen diagram …................................................................. 46

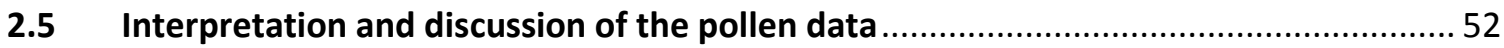

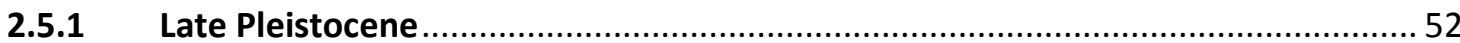

2.5.2 Transition from the Late Pleistocene to the early and mid-Holocene period ........ 54

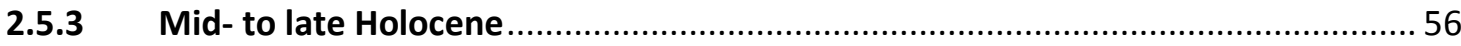

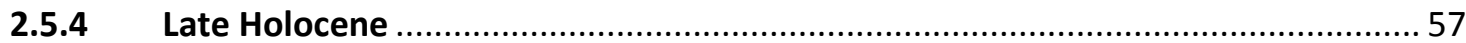

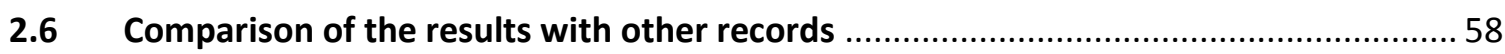

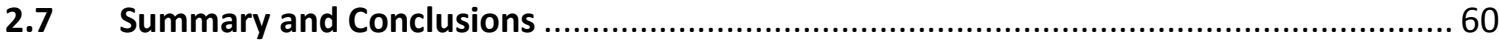

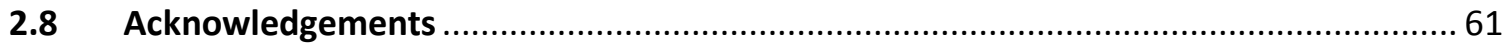

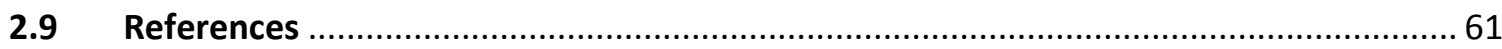

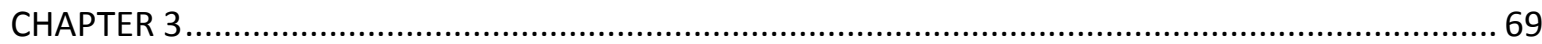

Late Glacial and Holocene environmental change inferred from the páramo of Cajanuma in

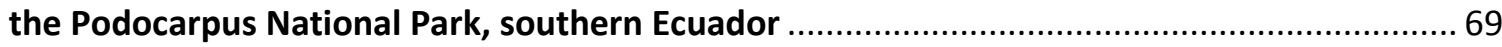

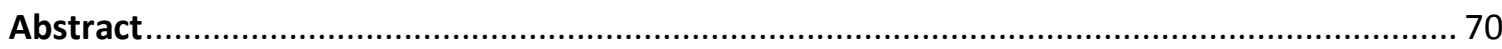




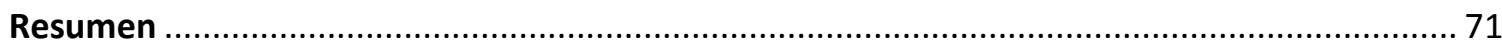

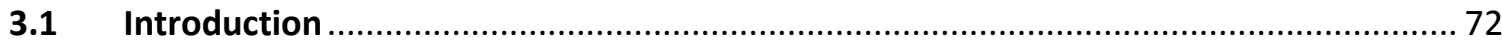

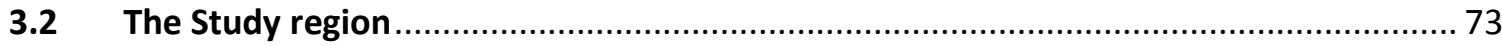

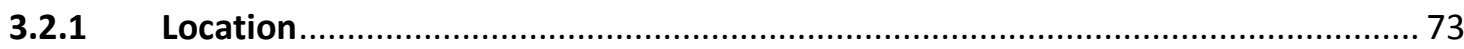

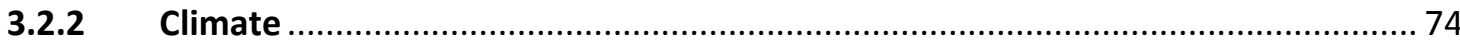

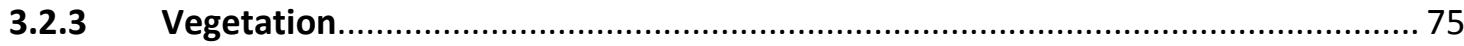

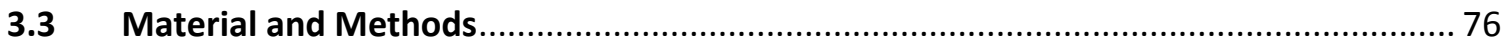

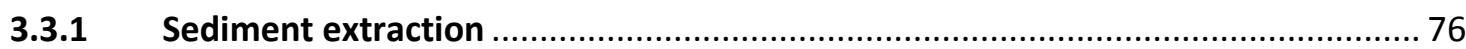

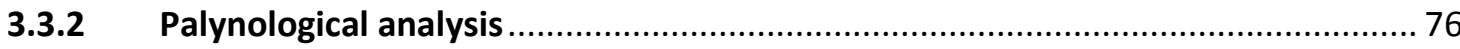

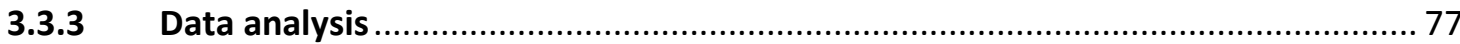

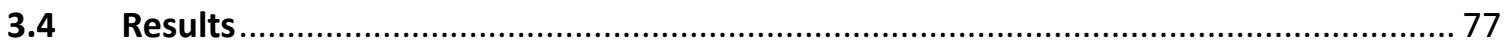

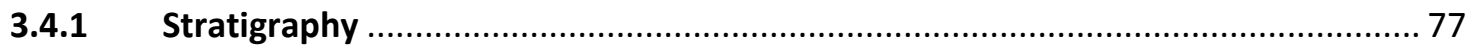

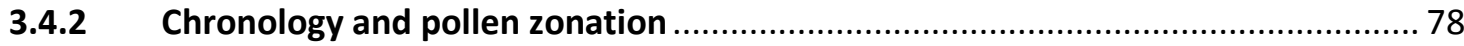

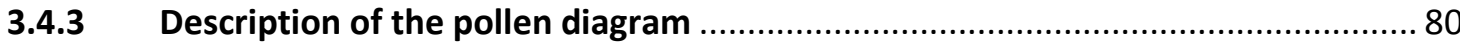

3.5 Interpretation and discussion of the environmental record ....................................... 85

3.5.1 Late Glacial and transition to the early Holocene ............................................. 85

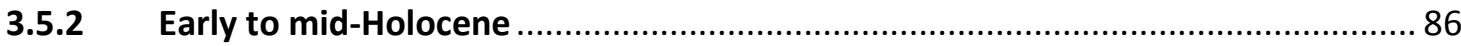

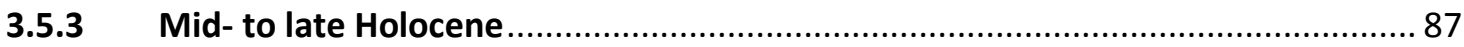

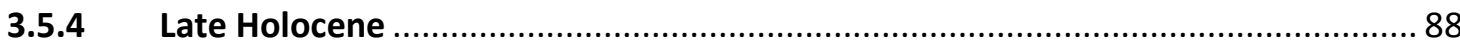

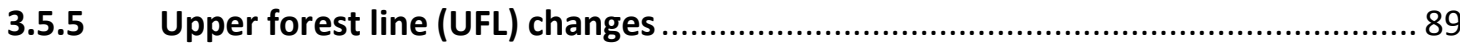

3.6 Comparison with other records from the Podocarpus National Park ..........................90

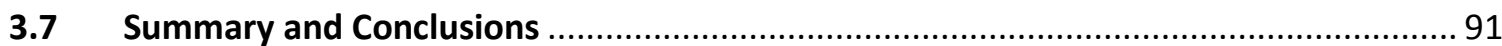

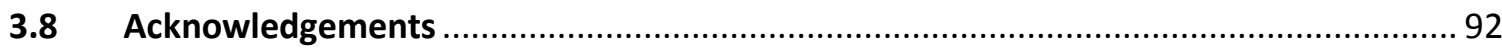

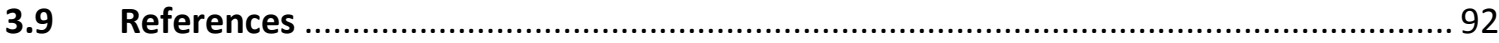

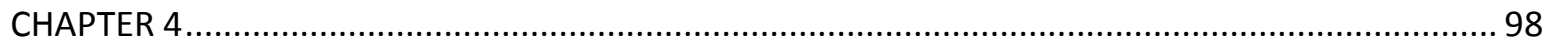

Mid- and late Holocene high resolution vegetation and environmental dynamics in the Llanganates National Park, Anteojos Valley, central Ecuadorian Andes................................. 98

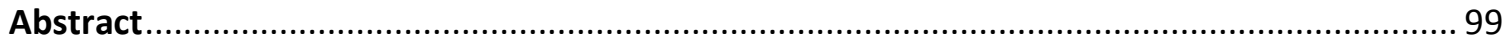

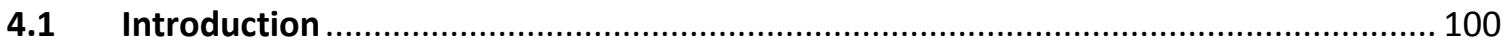

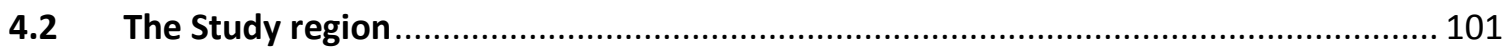

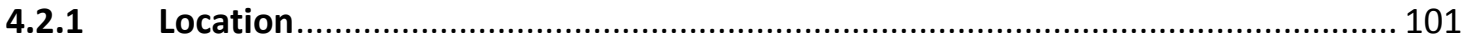

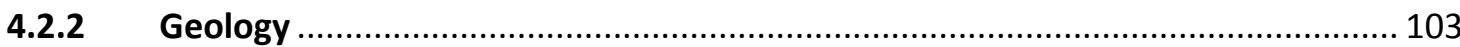




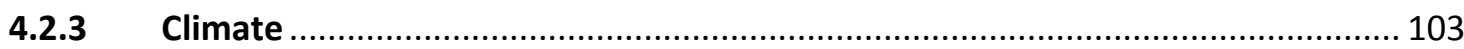

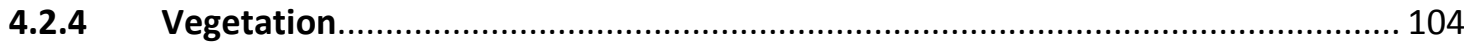

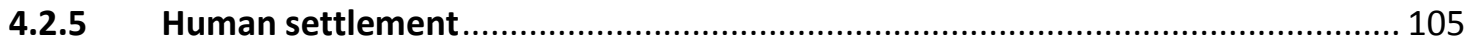

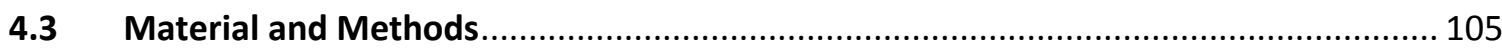

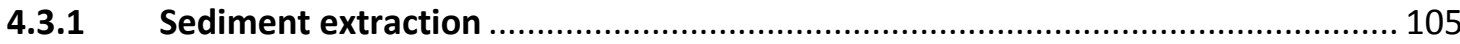

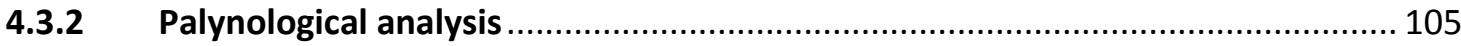

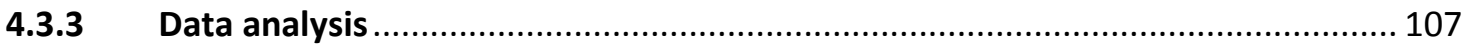

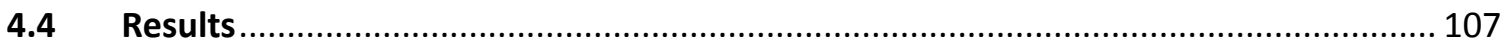

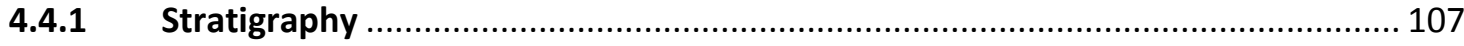

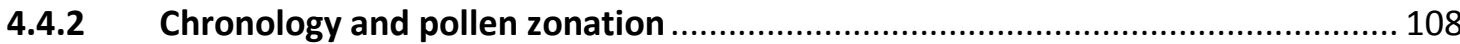

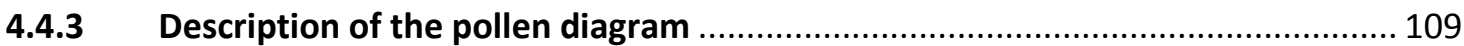

4.5 Interpretation and discussion of the environmental record .................................. 114

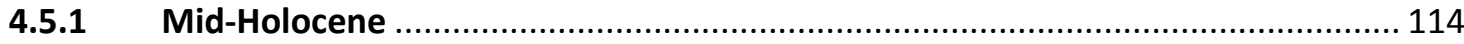

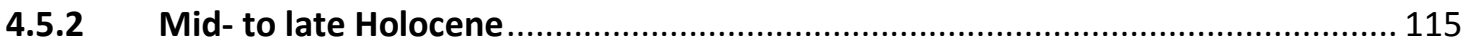

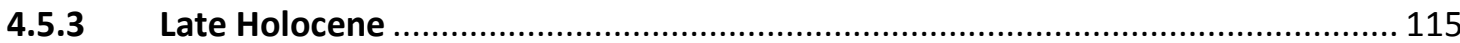

4.6 Comparison of the results with other records ...................................................... 116

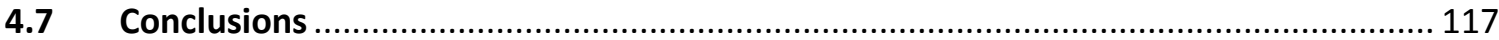

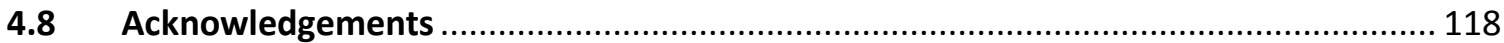

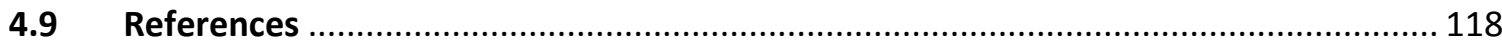

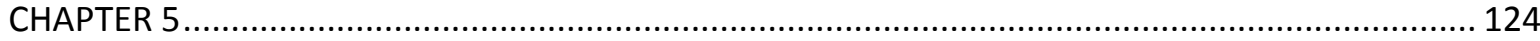

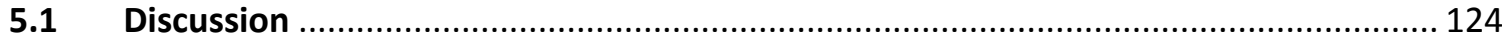

5.1.1 Late Pleistocene vegetation and climate dynamics at key sites in the Central and

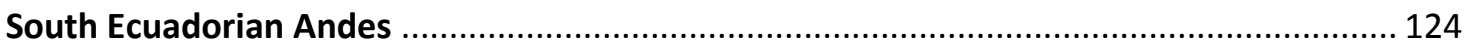

5.1.2 Fire and Human Impact in the Central and South Ecuadorian Andes landscapes 127

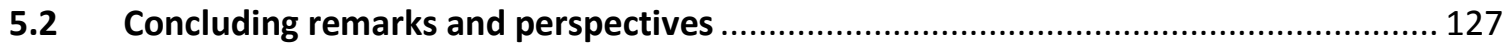

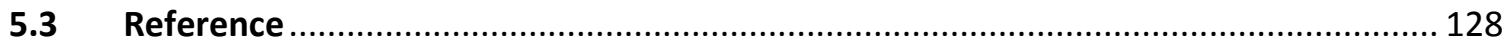

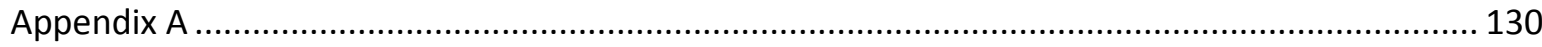

1.1 List of identified pollen and spores taxa grouped into the four major vegetation types

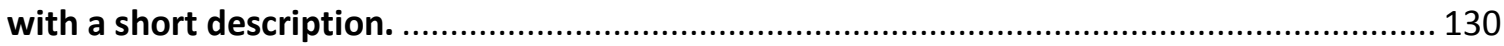

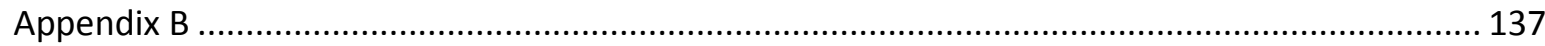

1.2 Pollen and spores photo plates for the most common identified taxa ...................... 137 
Appendix C

1.3 Complete palynological diagrams of identified pollen grains and spores for the three

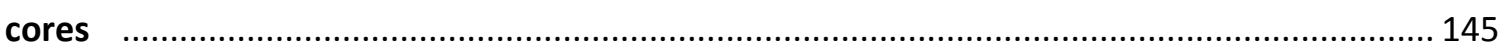

1.3.1 El Cristal complete record percentage diagram ............................................. 146

1.3.2 Cajanuma valley complete record percentage diagram ................................... 150

1.3.3 Anteojos valley complete record percentage diagram ...................................... 154 



\section{Acknowledgements}

The last three years I spent working on my PhD dissertation certainly brought major transformations to my entire life as a result of new and challenging experiences, real good friendships and team work. Therefore, this dissertation would not have been possible without the help of so many people in so many ways and to whom I am greatly indebted.

First of all, my special thanks go to my supervisor, Professor Hermann Behling who kindly gave me the opportunity to work in this dissertation and introduced me to the science of palynology. Also, I am grateful for his support during this time of research at the Department of palynology and Climate Dynamics and during my stay in Göttingen.

Also, I want to thank to my Co-Supervisor Professor Markus Hauck and my third supervisor Dr. Dirk Gansert for their suggestions and comments during my research.

Many thanks to M.Sc. Susana León Yánez, from the Pontificia Universidad Católica del Ecuador, who apart of provide me a working space, shared data and knowledge about the dynamics of the Páramo vegetation.

I especially thank Nele Jantz who always maintained the good spirit, introduced me to the German culture and share with me scientific and social company. Also, for the best company during the field work around the Podocarpus National Park.

Also, many thanks to the colleagues from the Department of Palynology and Climate Dynamics who shared their scientific knowledge, nice company and congeniality with me. In this context I especially thank Siria Biagioni, Jörg Christiansen, Sonia Fontana, Thomas Giesecke, Ulla Grothmann, Anggi Hapsari, Barbara Hermanowski, Nele Jantz, Vivian Jeske-Pieruschka, Alejandra Leal, Isabelle Matthias, Waheed Murad, Anastasia Poliakova, Jackson Rodrigues, Paula Rodríguez, Lisa Schüler, Geggensuvd Tserendorj and Liang-Chi Wang 
Thanks to all the staff members of the San Francisco Scientific Research Station (ECSF), especially Jörg Zeilinger, Felix Matt and the drivers Abraham, Tati, Roberth and Daniel for the safety driving and accommodation, logistic support and practical help during the field work.

Many thanks also to my friends Corinna Brunschön, Jorge Castillo, Noemí Cevallos, Gloria Del Alcázar, Santiago García, Carlos Iñiguez, Sofía López, Alejandra Moscoso, Fernando Rodríguez, María Fernanda Tapia and Santiago Yeroví for being there for me at all times, encouraged me and help me to gather strength.

I am very thankful to my family, my parents Jorge and Adriana, my sister Stephany, my brother Sebastián, my uncles Kanya and Rebeca and my grandmother Isabel for supporting and encouraging me at all times. It would never have been possible for me to successfully conclude my research without them.

Finally, I would like to thank the Deutsche Forschungsgemeinschaft (DFG) Research Unit FOR816 "Biodiversity and sustainable management of a megadiverse mountain ecosystem in southern Ecuador" and our subproject D1 "Analysis and synthesis of palaeoecological data revealing patterns of mountain vegetation and plant diversity dynamics and its response to climate, fire, land use changes in biodiversity hotspots through space and time". 


\section{Summary}

The Ecuadorian Andes in northwestern South America are well known for being among the hot spots of global vascular plant diversity due to their complex topography (uplift of the mountain chain), varying climatic conditions and different vegetation types. Despite its high biodiversity level, the Ecuadorian Andes represent a most threatened and poorly studied landscape. Especially the páramo and mountain ecosystems are subject to overgrazing, burning, cultivation and deforestation caused by the expansion of human activity during the last decades.

The knowledge of palaeoecology and landscape dynamics is important in order to understand past processes that played a major role in the development of the ecosystems and Ecuadorian landscapes of today. Nevertheless only a limited number of palaeoecological studies are available from the Ecuadorian Andes. This thesis presents palynological analyses carried out at three different sites in the central and southern Ecuadorian Andes region to better understand the past vegetation changes, climate and fire dynamics as well as human impact since the late Pleistocene.

The analysis of the sediment core El Cristal, located on the eastern slope at the Protective Forest Corazón de Oro in southeastern Ecuador reveals changes in the vegetation distribution, climate, fire regime and human impact since late Pleistocene. During the late Pleistocene mountain forest was the main vegetation type. In particular, there is evidence of a Polylepis forest which does not occur today. Nevertheless there is also evidence of relatively high proportion of páramo, which suggest that an open mountain forest occupied the region. The presence of páramo taxa during the late Pleistocene, points to an upper forest line (UFL) at a markedly lower elevation. The transition from the late Pleistocene to the early mid-Holocene was characterized by mountain forest and a stable proportion of páramo vegetation. However, after ca. $4000 \mathrm{cal} \mathrm{yr}$ BP, the Polylepis forest decreased, probably because of an increase in fire frequency. During the mid- to late Holocene the composition of the vegetation changed. The mountain forest was less frequent and the páramo vegetation expanded. Higher proportions of Asteraceae and Muehlenbeckia/Rumex (since ca. $1380 \mathrm{cal}$ yr BP) reflect landscape disturbance probably by human impact. Fires were recorded throughout the late Pleistocene but were more frequent during the 
wetter late Holocene, which suggests that they were of anthropogenic origin. The pollen record from Cajanuma valley, in the western slope at the Podocarpus National Park, southern Ecuador, reveals environmental changes since the late Glacial. During the late Glacial, herb páramo rich in Poaceae, Cyperaceae and Gentianaceae covered the area. The UFL occurred at a much lower elevation than today. The early to mid-Holocene is characterized by partial replacement of treeless páramo by a mountain forest (Symplocos taxa), which moves into higher elevations where it is today. During the mid- to late Holocene there is evidence of a vegetation change. The páramo reexpanded with the dominance of Poaceae and high presence of Huperzia and Cyatheaceae. During the late Holocene páramo was the main vegetation type that covered the area. Fires became frequent since the late Holocene. The Anteojos valley pollen record, which is located in the western slope at the Llanganates National Park, central Ecuadorian Andes, yields a detailed environmental reconstruction of the past ca. 4100 years. Páramo vegetation had a dominant and stable occurrence in the study area (Poaceae, Cyperaceae and Asteraceae); especially between ca. 4100 to 3100 cal yr BP. Between ca. 3100 to 2100 cal yr BP páramo decreased followed by a slight expansion of mountain forest (Moraceae/Urticaceae, Trema, Celtis and Macrocarpaea). From ca. $2100 \mathrm{cal}$ yr BP to the present páramo once again became more frequent with stable occurrence of mountain forest taxa. Low frequencies of fires were evidenced throughout the record but there is evidence of a slight increase during ca. 4100 to $3100 \mathrm{cal}$ yr BP. 


\section{Resumen}

Los Andes ecuatorianos, ubicados en el noroeste de América del Sur son considerados un "hotspot" con una alta diversidad mundial de plantas vasculares, debido a su compleja topografía (elevación de la cordillera), variaciones de las condiciones climáticas y los distintos tipos de vegetación. A pesar de su elevado nivel de biodiversidad, los Andes ecuatorianos presentan uno de los paisajes más amenazados y poco estudiados. Especialmente los ecosistemas de páramo y montaña están sujetos a sobrepastoreo, quemas, cultivos y la deforestación causada por la expansión de la actividad humana en las últimas décadas.

El conocimiento sobre paleoecología y la dinámica del paisaje es clave para entender los procesos del pasado que tuvieron un papel importante en el desarrollo de los ecosistemas y los paisajes ecuatorianos actuales. Sin embargo sólo un número limitado de estudios paleoecológicos de los Andes ecuatorianos están disponibles. En esta tesis se presentan análisis palinológicos que se llevaron a cabo en tres sitios diferentes en la región centro y sur de los Andes de Ecuador, con el fin de comprender mejor los últimos cambios en la vegetación, el clima y la dinámica del fuego; así como el impacto humano desde finales del Pleistoceno.

El análisis del núcleo de sedimento El Cristal, ubicado en la ladera oriental de la cordillera Oriental en el Bosque Protector Corazón de Oro en el sureste del Ecuador, revela cambios en la distribución de la vegetación, el clima, el régimen de incendios y el impacto humano desde finales del Pleistoceno. Durante el Pleistoceno tardío el bosque montano fue el principal tipo de vegetación. Especialmente, hay evidencia de bosque de Polylepis lo que no ocurre en la actualidad. Sin embargo pruebas de proporciones relativamente altas de páramo sugiere que un bosque montano abierto ocupó la región. Por otro lado la presencia de taxones de páramo durante el Pleistoceno tardío, propone que la línea superior del bosque se encontraba a una altura inferior. Así mismo, la transición del Pleistoceno tardío al Holoceno temprano y medio se caracteriza por la presencia de bosque montano y una proporción estable de la vegetación de páramo. Sin embargo, después de aproximadamente 4000 cal yr BP, el bosque de Polylepis disminuyó, probablemente debido a un aumento en la frecuencia de incendios. Durante el Holoceno medio y tardío la composición de la 
vegetación cambió, el bosque montano fue menos frecuente y la vegetación de páramo se expandió. Altas proporciones de Asteraceae y Muehlenbeckia/Rumex (desde ca. 1380 cal yr BP) reflejan alteraciones del paisaje, probablemente por el impacto humano. Además, se registraron incendios durante todo el Pleistoceno tardío, pero fueron más frecuentes durante el Holoceno tardío, esto sugiere que eran de origen antropogénico. Por otro lado, El registro de polen Cajanuma valle, en la ladera occidental de la cordillera Oriental del Parque Nacional Podocarpus, sur de Ecuador, revela los cambios ambientales desde el último Glacial. Durante el último Glacial, páramo herbáceo principalmente dominado por Poaceae, Cyperaceae y Gentianaceae cubrió la zona. La línea superior del bosque se localizó a una altura más baja que la actual. El Holoceno temprano y medio se caracterizó por una sustitución parcial de páramo por bosque montano (Symplocos), el cual cambió su posición a elevaciones más altas donde está actualmente. Durante el Holoceno medio y tardío hay evidencia de un cambio de la vegetación, el páramo se re-expande con el predominio de Poaceae y alta presencia de Huperzia y Cyatheaceae. Durante el Holoceno tardío el páramo fue el principal tipo de vegetación que cubrió la zona. Los incendios se hicieron frecuentes desde el Holoceno tardío. Finalmente, el récord de polen Anteojos valle, que se encuentra en la ladera occidental del Parque Nacional Llanganates, en los Andes ecuatorianos centrales, presenta una reconstrucción ambiental detallada de aproximadamente los últimos 4100 años. La vegetación de páramo tuvo una ocurrencia dominante y estable en el área de estudio (Poaceae, Cyperaceae y Asteraceae); especialmente entre ca. 4100 - 3100 cal yr BP. Entre ca. 3100 - 2100 cal yr BP hubo una disminución de la vegetación de páramo seguido de una ligera expansión del bosque montano (Moraceae/Urticaceae, Trema, Celtis y Macrocarpaea). Desde ca. 2100 cal yr BP hasta la actualidad, la vegetación de páramo una vez más se hizo frecuente con una incidencia estable de los taxones del bosque montano. Se evidenció una baja frecuencia de incendios a lo largo del núcleo de sedimento; sin embargo, es evidente un ligero aumento entre ca. 4100 - 3100 años cal BP. 


\section{Zusammenfassung}

Zusammenfassung Die ecuadorianischen Anden im nordwestlichen Südamerika sind bekannt dafür, wegen ihrer komplexen Topografie (Erhebung der Bergkette), variierender klimatischer Einflüsse und verschiedener Vegetationstypen zu den Hot-Spots der Diversität der vaskulären Pflanzen zu gehören. Trotz des hohen Artenreichtums sind die ecuadorianischen Anden eine höchstgefährdete und nur spärlich untersuchte Landschaft. Besonders der Páramo und die Bergökosysteme sind durch die Ausbreitung der menschlichen Aktivitäten der letzten Dekaden Überweidung, Bränden, Kultivierung und Abholzung ausgesetzt.

Das Wissen über Paläoökologie und Landschaftsdynamik ist wichtig, um die vergangen Prozesse, die eine wichtige Rolle in der Entwicklung der Ökosystems und Landschaften des heutigen Ecuadors gespielt haben, zu verstehen. Dennoch ist nur eine begrenzte Anzahl plaäoökologischer Studien aus den ecuadorianischen Anden verfügbar. In dieser Arbeit werden playnologische Untersuchungen dreier verschiedener Standorte aus den südlichen und zentralen Anden Ecuadors vorgestellt, die dazu beitragen, vergangene Vegetationsveränderungen, Klima- und Feuerdynamik sowie den menschlichen Einfluss seit dem späten Pleistozän besser zu verstehen.

Die Analyse des Sedimentkerns „El Cristal“ vom Osthang des Waldschutzgebietes Corazón de Oro im südöstlichen Ecuador zeigt Veränderungen in der Verbreitung der Vegetation, des Klimas, des Feuersregimes, sowie des menschlichen Einflusses seit dem späten Pleistozän. Während des späten Pleistozäns war Bergwald der vorherrschende Vegetationstyp. Im Speziellen war der Wald durch Polylepis geprägt, eine Baumart, die heute nicht mehr in der Region vorkommt. Trotzdem gibt es Anzeichen für relativ hohe Anteile von Páramo, was auf die Präsenz eines offenen Waldes in der Region schließen lässt. Die Gegenwart von Páramo-Taxa während des späten Pleistozäns lässt darauf schließen, dass die Waldgrenze auf einer merklich tieferen Höhenstufe war. Der Übergang vom späten Pleistozän zum frühen bis mittleren Holozän ist durch Bergwald und eine stabilen Anteil an Páramovegetation gekennzeichnet. Nach etwa 4000 cal yr BP ist der PolylepisWald, vermutlich wegen der erhöhten Feuerhäufigkeit, zurückgegangen. Während des mittleren bis späten Holozäns verändert sich die Zusammensetzung der Vegetation. Die Bergwaldtaxa sind 
weniger Häufig und der Páramo expandiert. Höhere Anteile von Asteraceae und Mühlenbeckia/Rumex (seit ca. 1380 cal yr BP) spiegeln eine Störung in der Landschaft, vermutlich durch menschlichen Eingriff, wider. Feuer können während des späten Pleistozäns nachgewiesen werden, werden aber im Verlauf des feuchten Spätholozäns häufiger, was auf eine anthropogene Herkunft schließen lässt.

Der Pollenrecord aus dem Cajanuma-Tal am Westhang des Podocarpus Nationalparks im südlichen Ecuador zeigt Umweltveränderungen seit dem Spätglazial. Während des Spätglazials bedeckt eine krautige Páramovegetation das Gebiet, die reich an Poaceen, Cyperaceen und Gentianaceen ist. Die obere Waldgrenze ist auf einer wesentlich tieferen Lage als heute. Das frühe bis mittlere Holozän ist durch einen partiellen Austausch des baumlosen Páramos durch einen Bergwald gekennzeichnet (Symplocos-Taxa), welcher in höhere Gebiete vordringt wo er noch heute zu finden ist. Während des mittleren bis späten Holozäns gibt es Hinweise für eine Veränderung der Vegetation. Das Páramo breitet sich unter Dominanz von Poaceen und hoher Präsenz von Huperzia und Cyatheaceen aus. Während des späten Holozäns war der Páramo der häufigste Vegetationstyp und bedeckte das Gebiet. Feuer wurden häufig seit dem dem späten Holozän.

Der Anteojos-Tal Pollenrecord vom Westhang des Llanganates Nationalparks in den zentralen Anden Ecuadors, birgt eine detaillierte Umweltrekonstruktion der letzten ca. 4100 Jahre. Das Vorkommen von Páramovegetation in der Region ist dominierend und stabil (Poaceen, Cyperaceen und Asteraceen), besonders zwischen ca. 4100 und 3100 cal yr BP. Zwischen ca. 3100 und 2100 cal yr BP geht der Páramo zurück, es folgt eine geringfügige Ausbreitung des Bergwaldes (Moraceae/Urticaceae, Trema, Celtis und Macrocarpaea). Von etwa 2100 cal yr BP bis heute breitet sich der Páramo wieder aus, jedoch mit stabilem Auftreten von Bergwaldtaxa. Geringe Feuerhäufigkeiten sind im ganzen Record zu finden, jedoch kann zwischen ca. 4100 und $3100 \mathrm{cal}$ yr BP ein leichter Anstieg nachgewiesen werden. 



\section{CHAPTER 1}

\section{Introduction}

\subsection{General context: scientific research of a mega-diverse ecosystem, the Ecuadorian Andes}

The tropical northern Andes are amongst the most diverse regions on earth with high species diversity. They represent one of the five global centers of vascular plant diversity with more than 5000 species of vascular plants per 10,000 km² (Mutke and Barthlott 2005, Barthlott et al. 2007, Mutke et al. 2011). The Ecuadorian Andes covers an area of about 45,000 $\mathrm{km}^{2}$ and encompass a wide range of climate, geology and soil conditions. They are considered an important biodiversity hot-spot, with almost 2900 endemic species (León-Yánez et al. 2011). Balslev (1988) estimated that in the Ecuadorian Andes between 900 and $3000 \mathrm{~m}$ of altitude, $49 \%$ of the plant species of the whole country can be found. Jørgensen and Ulloa Ulloa (1994) reported ca. 4430 species between 2400 and $5000 \mathrm{~m}$ a.s.I corresponding to the $22-27 \%$ of all vascular plant species in the country, further underlining the high level of biodiversity of this region.

Despite their importance for biodiversity, the Ecuadorian Andes are experiencing high degradation. Official sources report that, between 1990 and 2010, Ecuador deforestation rate was 3,952,000 ha/year, corresponding to $28.6 \%$ of forest cover (Mosandl et al. 2008, www.mongabay.com). In addition, fire, cultivation and overgrazing lead to serious environmental problems such as the decrease of water retention capacity which leads to increase in soil erosion (Podwojewski et al. 2006). Studies estimated that, only $4 \%$ of the forests on the western Ecuadorian Andes remain untouched and following the increasing in human impact during the last decades, almost no natural forests are left in the Central Valley (Dodson and Gentry 1991).

Due to the endangered and relatively unexplored status of these ecosystems, Ecuadorian and German research groups have been carrying on scientific research the eastern Ecuadorian Andes. Since 2000, the Deutsche Forschungsgemeinschaft (DFG) has been working in the southern 
Ecuadorian Andes. In 2007, the DFG started a new Research Unit, the 816: "Biodiversity and Sustainable Management of a Megadiverse Mountain Ecosystem in South Ecuador"; which focused on ecosystem functioning and sustainable land use management strategies in a biodiversity hotspot. Most of research activities were concentrated in the Podocarpus National Park and the ca. $11.2 \mathrm{~km}^{2}$ core area of the Reserva Biológica San Francisco at the border between the Ecuadorian provinces of Loja and Zamora Chinchipe southern Ecuador. Within this Research Unit, starting from 2010 the subproject A1: "Analysis and synthesis of palaeoecological data revealing patterns of mountain vegetation and plant diversity dynamics and its response to climate, fire, land use changes in biodiversity hotspots through space and time" (www.bergregenwald.de) focused on the investigation of the late Quaternary landscape dynamics in the Podocarpus National Park region and surrounding areas. The aim was to increase the knowledge on how past processes have influenced ecosystems dynamics and the development of the outstanding diversity in the study region and to provide long-term ecological perspective, essential when planning and defining management and conservation strategies.

Throughout the 2007 to 2013 many palaeoecological studies have been carried out, resulting in a good overview of local and regional past environmental changes during the late Quaternary. In particular, the RU 816 with the subproject A1 provided the framework for the present dissertation.

\subsection{Palynological and palaeoecological research in the northern tropical Andes}

\subsubsection{Previous research of palaeoecological research in the Ecuadorian Andes}

Despite the fact that palaeoecological studies are very fundamental to understand the long-term vegetation dynamics in relation to climate and human impact, such research activities are still rare in the Ecuadorian Andes. The main restraint has to be ascribed to the difficult logistic, being the region characterized by steep topography and scarcity of natural archives (Bush et al. 2011). Only few studies are located in the central and northern Ecuadorian Andes (e.g. Colinvaux et al. 1988, Clapperton et al. 1997, Hansen et al. 2003, Rodbell et al. 2002, Van der Hammen et al. 2003; Di Pasquale et al. 2008, Bakker et al. 2008), whereas more palaeoecological investigations were carried out by the German-Ecuadorian Research Unit in the southern Ecuadorian Andes at altitudes above 3,300 m a.s.I, including the Podocarpus National Park (PNP) and surrounding areas (e.g. Niemann and Behling 2008, 2010, Brunschön and Behling 2009, 2010, Niemann et al. 2009, 
2013, Brunschön et al. 2010, Rodríguez and Behling 2011, Villota et al. 2012, Villota and Behling 2013) (Fig. 1). Those studies characterized past vegetation as well as climate changes. Generally, the last glacial period is marked by cold and wet conditions, followed by warm and dry early to mid-Holocene. The late Holocene recorded wetter conditions. Interestingly, the reconstructions show the environment has changed as a consequence of changing fire intensity and human impact regimes, highlighting the importance of those factors in driving local and regional ecosystem dynamics during the late Quaternary.

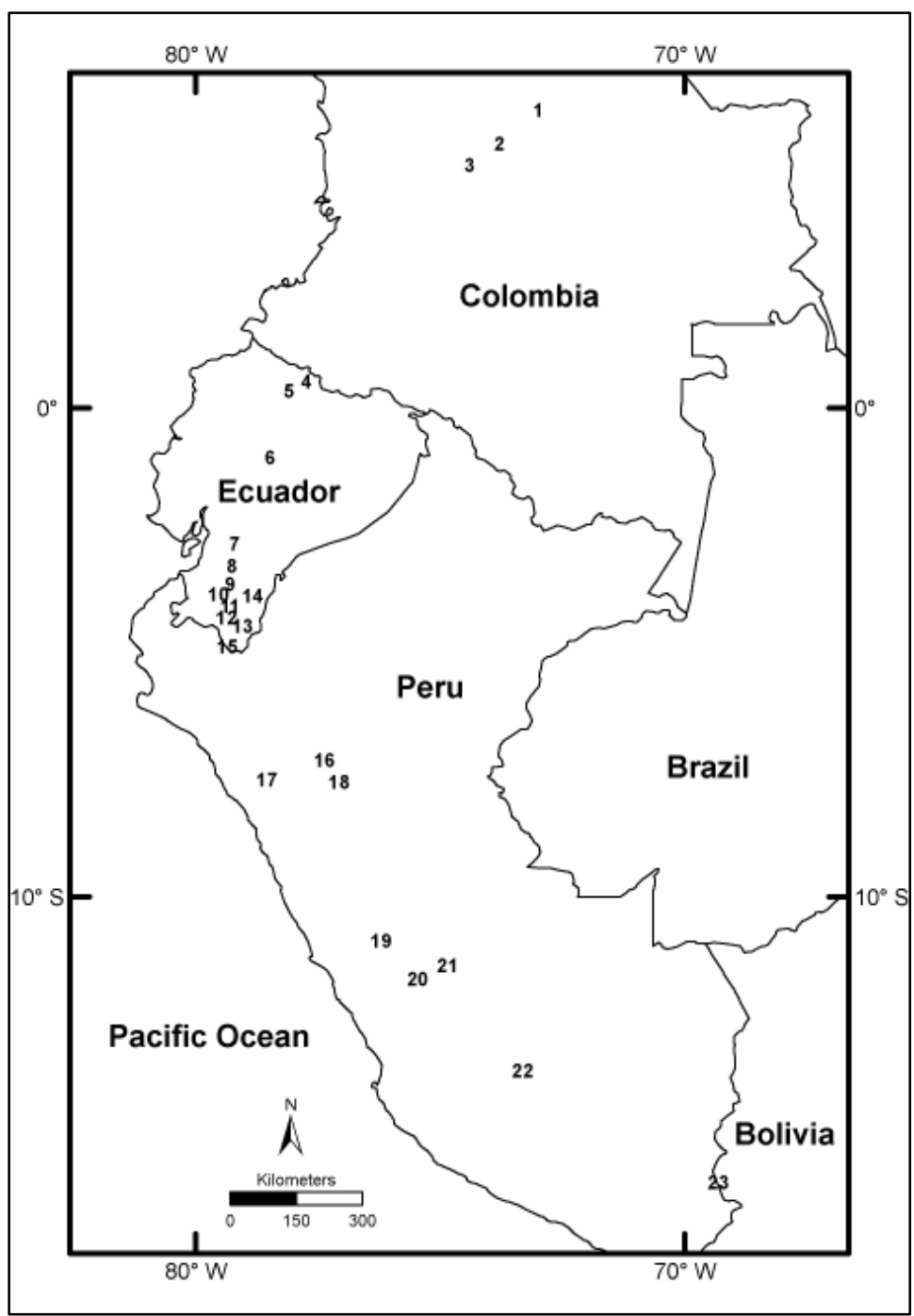

Figure 1. Map of northwestern South America, showing the location of the different study sites from the Ecuadorian Andes and neighboring countries. 1. Cienega del Visitador; 2. Lake Fuquene; 3. Agua Blanca; 4. Guandera Biological Reserve; 5. Laguna Yaguarcocha; 6. Anteojos valley; 7. Laguna Pallcacocha; 8. Tres Lagunas; 9. Cocha Caranga; 10. Valle Pequeño; 11. Cajanuma valley; 12. Laguna Rabadilla de Vaca; 13. Cerro Toledo; 14. El Cristal; 15. Lagunas Natosas; 16. Laguna La Compuerta 17. Laguna Baja; 18. Laguna de Chochos; 19. Laguna Junín; 20. Lagunas Pomacocha; 21. Laguna Tuctua; 22. Laguna Pacucha; 23. Lake Titicaca. 


\subsubsection{Reconstruction of the vegetation and climate history since the late Pleistocene}

Several palaeoecological studies from Colombia, Peru, Bolivia and also Ecuador have shown that during the late Quaternary (in particular from the late Pleistocene to the Holocene) marked climatic changes, vegetation dynamics and anthropogenic impact have influenced the formation of different types of ecosystems (Fig.2).

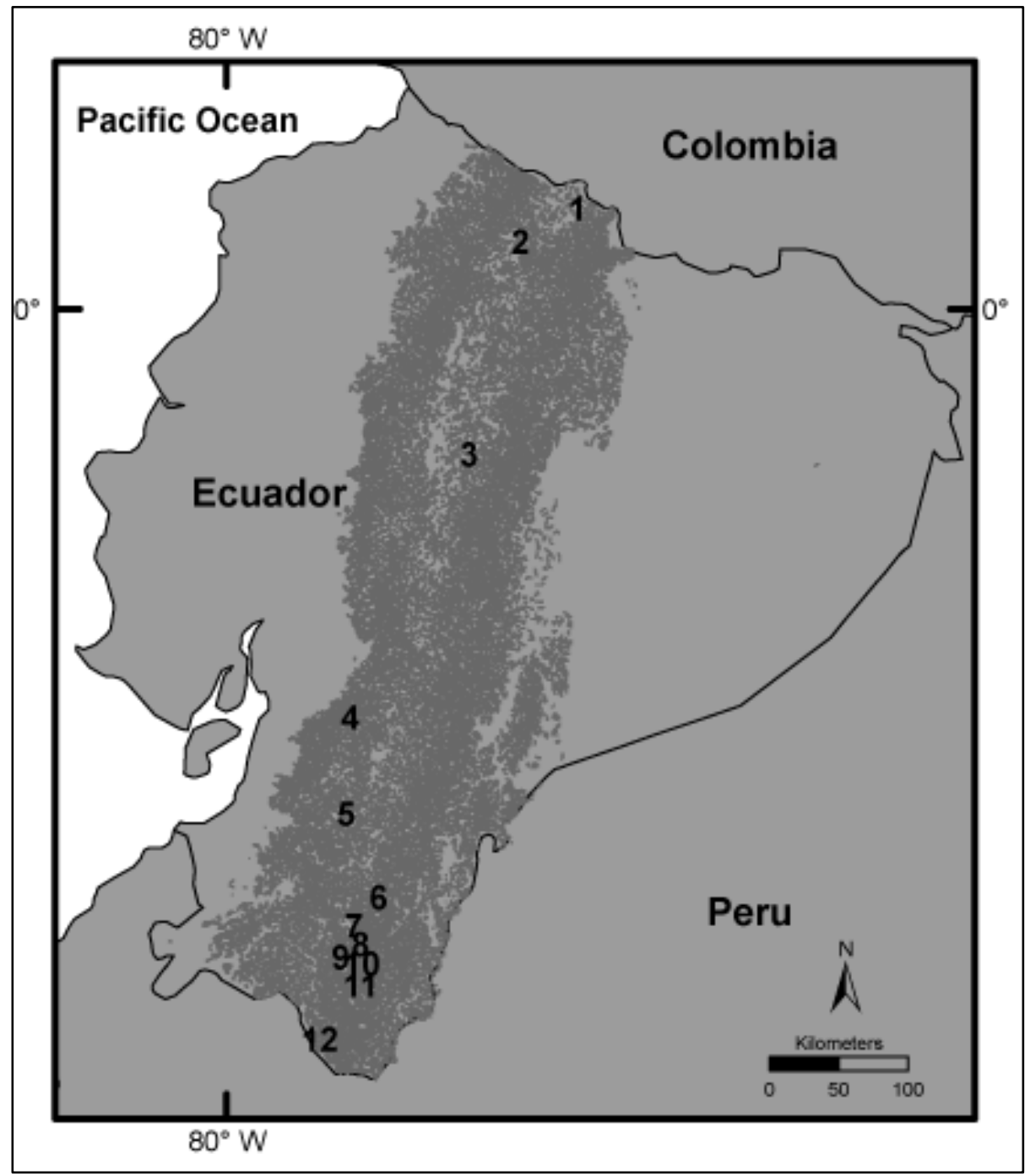

Figure 1. Map of the Ecuadorian Andes, showing the location of the different studiy sites. 1. Guandera Biological Reserve; 2. Laguna Yaguarcocha; 3. Anteojos valley; 4. Lagunas Chorreras; 5. Tres Lagunas; 6. El Cristal; 7. Cocha Caranga; 8.Valle Pequeño; 9. Cajanuma valley; 10. Laguna Rabadilla de Vaca; 11. Cerro Toledo; 12. Lagunas Natosas. 


\section{a. Late Pleistocene (ca. 20,000 -11,500 cal yr BP)}

The late Pleistocene is characterized by periods of rapid landscape and climatic changes (Bush et al. 2011). The process of deglaciation began with the Bølling/ Allerød (B/A) warming (ca. 14,700 to $14,000 \mathrm{yr}$ BP) followed by the Younger Dryas cold event (ca. 12,900 to 11,600 cal yr BP) (Rodbell and Seltzer 2000). In Ecuador signals of the warmer Bølling/ Allerød (B/A) interstadial and the cooler Younger Dryas event are not as clear (Bush et al. 2011) as in other areas (for e.g. Colombia: Van der Hammen and Hooghiemstra 2003). Several records from Ecuador show that during the late Pleistocene, the climate was cooler and more moisture (Colinvaux et al. 1988, 1997, Hansen et al. 2003, Niemann and Behling 2008, Brunschön and Behling 2009, Niemann et al. 2009) compare to modern conditions. From the records in Colombia it is estimated that temperatures during the late Pleistocene (Last Glacial Maximum) were ca. 6 to $8{ }^{\circ} \mathrm{C}$ lower than today (Wille et al. 2001, Vélez et al. 2006). In addition, records from Peru and Bolivia suggest wetter conditions (Baker et al. 2001).

\section{b. Early Holocene (ca. 11,500-8000 cal yr BP)}

The early Holocene was a period of great transitions in which a progressive but intermittent global warming took place (Jørgensen and León Yánez 1999). Studies by Bush and Gosling (2012) suggest that sites close to the equator became warmer and drier at the beginning of the early Holocene (ca. 11,500 cal yr BP). This changed at ca. 8500 cal yr BP, as studies from lakes in Colombia and Peru point out that moist and warm conditions established, indicated by the increase of humid forest taxa (Hansen and Rodbell 1995, Hansen et al. 1994, Marchant et al. 2002, Vélez et al. 2006). Especially in Peru, studies show that forest expansion was facilitated during the thermal optimum warm event between ca. 10,000 to 6000 yr BP. In the southern Ecuadorian Andes studies indicate an increase in temperature and an expansion of mountain forest into higher elevations (Colinvaux et al. 1988, Hansen et al. 2003, Bakker et al. 2008, Brunschön and Behling 2009, Niemann and Behling 2008, 2009, Niemann et al 2009). Summarizing, during the early Holocene alternating wetter and drier phases are evident.

\section{c. Mid-Holocene (ca. $8000-3000$ cal yr BP)}

The mid-Holocene is characterized by warmer and drier conditions in the west and central Andean region of Ecuador, in Peru and Bolivia (Hansen et al. 2003, Paduano et al. 2003, Weng et al. 2006, Jantz and Behling 2012) as well as in the eastern Andes of Colombia (Vélez et al. 2006). However, 
more recently, new palaeoenvironmental studies describe this period as one of increased drought frequency punctuated by episodic wet events, rather than as a single dry 'event' (Paduano et al. 2003, Bush et al. 2005, Valencia et al. 2010). During this period an increase in the spread of shrubs is evident into the páramo area.

\section{d. Late Holocene (ca. 3000 to present)}

The late Holocene is in general characterized by wetter and slightly cooler climatic conditions (Marchant et al. 2002, Abbott et al. 2003, Weng et al. 2006, Niemann and Behling 2008, 2009, Urrego et al. 2011). In particular, records from central Peruvian Andes reveal declining temperatures between 3000 to 1000 yr BP (Hansen et al. 1994).

\section{e. Fire impact}

Evidences of fires are recorded since the late Pleistocene, showing that fire was and currently is an important ecological factor in these ecosystems. Nevertheless, low frequency of fires characterize the late Pleistocene, while during the Holocene fire occurrences increase, causing large-scale disturbance of the Andean landscapes (Di Pasquale et al. 2008). It is important to mention that, fires are not necessarily to be ascribed to human intervenes, as natural fires also occurred in the region. Despite the fact that the first human populations settled in South America already during the late Pleistocene (ca. 13,000-11,000 yr BP) (Silverman and Isbell 2008) fires recorded from the late Pleistocene until mid-Holocene can reasonably be explained as result of drier climate influences, unless evidence of human impact is found in pollen records (Wille et al. 2002, Hansen et al. 2003). However, during the wetter late Holocene, increased fire intensity is thought to be of anthropogenic origin (Weng et al. 2006, Niemann and Behling 2009, Jantz and Behling 2012). The impact of human populations on the landscape becomes more important in most of the sites during the late Holocene, as shown by the increasing presence of indicators for local agriculture and land-use disturbance (e.g. pollen grains of Zea mays, Alnus, Ambrosia and Muehlenbeckia/Rumex) (Hansen et al. 2003, Gómez et al. 2007, Brunschön and Behling 2009, Valencia et al. 2010). 


\subsection{The study region}

\subsubsection{Location}

The study sites are located in the Andes, Cordillera Real, of Central (Llanganates National Park) and South Ecuador (Podocarpus National Park and Protective Forest Corazón de Oro).

\section{a. El Cristal}

The El Cristal region is found at the southeastern slope of the Cordillera Real in an open forest area of the Protective Forest Corazón de Oro (PFCO), in the Andean Depression. The PFCO is part of the Loja and Zamora provinces and covers 54,000 ha. The altitude range is between 1360 and $3400 \mathrm{~m}$ a.s.I. The study site is located at $2056 \mathrm{~m}$ a.s.I. (S $3^{\circ} 51^{\prime} 38.5^{\prime \prime}$ and $W 79^{\circ} 03^{\prime} 40.1^{\prime \prime}$ ) in the Zamora Province (See chapter 2).

\section{b. Cajanuma valley}

The Cajanuma valley is located on the southwestern slope of the Cordillera Real in the páramo area of Podocarpus National Park (PNP), in the Andean Depression. The PNP is part of the Loja and Zamora Chinchipe provinces and covers an area of $1462 \mathrm{~km}^{2}$. The altitude range is between 900 and $3600 \mathrm{~m}$ a.s.l. The study site is located at $3285 \mathrm{~m}$ elevation $\left(4^{\circ} 08^{\prime} 59^{\prime \prime} \mathrm{S}, 79^{\circ} 09^{\prime} 25^{\prime \prime} \mathrm{W}\right)$ in the Loja province (See chapter 3).

\section{c. Laguna de Anteojos}

The Laguna de Anteojos basin is located at the eastern slope of the Cordillera Real in the páramo area of Llanganates National Park (LNP). The LNP is part of the Cotopaxi, Tungurahua, Napo and Pastaza provinces; it covers an area of 21900 ha and altitude ranges from 1200 to $4638 \mathrm{~m}$ a.s.l. The study site is located at an elevation of $3984 \mathrm{~m}$ (S $\left.0^{\circ} 57.946^{\prime} ; \mathrm{W} 78^{\circ} 24.397^{\prime}\right)$ in the Cotopaxi province (see Chapter 4).

\subsubsection{Geomorphological structure}

The Ecuadorian Andes represent a $650 \mathrm{~km}$ long and $150 \mathrm{~km}$-wide segment of the Andean mountain chain. Northern Ecuador consists of two parallel mountain ranges, the Western Cordillera and the Cordillera Real (Eastern Cordillera); which are separated by the intervening 
structural depression InterAndean Valley (Hall et al. 2008). In the southern Ecuadorian Andes, the Cordillera Real includes the so-called Andean Depression, which stretches from Girón-Cuenca in Ecuador to Huancabamba in northern Peru $\left(3-6^{\circ} \mathrm{S}\right)$ (Weigend 2002). Within the Andean Depression the highest peaks only reach up to about $4000 \mathrm{~m}$ a.s.l and active volcanoes and glaciers are absent (Schubert and Clapperton 1990). Nevertheless, indications of Pleistocene glaciations are found.

Compared to the low altitudes of the southern Ecuadorian Andes, the northern and central Ecuadorian Andes reach elevations of more than $6000 \mathrm{~m}$ a.s.l. and at least 20 active volcanoes are present. Several of them reach altitudes of 5000 to $6000 \mathrm{~m}$ and are glacier-clad. During the Holocene, the volcanoes of the Cordillera Real have been systematically more active than those of the Western Cordillera (Hall et al. 2008).

\subsubsection{Geology and soils}

The terrain of the southern Ecuadorian Andes is well-exposed and comprises granitic gneiss, schist, phyllite and quartzite. The terrain of the northern Ecuadorian Andes is mainly formed by younger volcanic deposits with inliers of mica, schist, quartz and amphibolite (Aspden and Litherland 1992). The El Cristal and Cajanuma regions belong geologically to the Loja division while the Laguna de Anteojos to the Salado division.

\section{a. El Cristal and Cajanuma valley}

The El Cristal and Cajanuma are part of the Loja division, which extends in the southern Ecuadorian Andes, between Cuenca and the Peruvian border. This division consists of a variety of rock types but essentially comprises variably metamorphosed, semi-pelitic rocks, metasedimentary rocks (garnet and staurolite), crystals of conspicuous and pale-blue quartz (Aspden and Litherland 1992).

The main soil type of the El Cristal and Cajanuma valley regions is Histosol, which is associated with Stagnosols, Cambisols and Regosols and a small proportion of Umbrisols and Leptosols (Liess et al. 2009).

\section{b. Laguna de Anteojos}

The Laguna de Anteojos basin geologically belongs to the Salado division and to the Llanganatis Groups metamorphic rocks. The Salado division is widespread to the northern Ecuadorian Andes 
above $3^{\circ} \mathrm{S}$ latitude. It has two principal divisions: the Azafran and volcano-sedimentary Upano. The Azafran subdivision is characterized by the Chingual and Sacha plutons which comprise variably deformed gneissic, coarse-to medium-grained, granodiorites and tonalities. The Upano subdivision is a mixed volcano sedimentary sequence which includes metamorphosed andesites, tuff and agglomerates, greywackes, marbles, impure quartzites and black phyllites (Apsden and Litherland 1992). The Llanganatis Groups metamorphic rocks also consist of quarts, gneiss and fine strips of marble (Kennerly and Bromley 1971).

Andosol is the dominant soil type in the northern Andes. It has very high water retention capacities (Buytaert et al. 2005), low temperature, acidic soil pH and includes formations of organo-metallic or organo-mineral complexes that resist decomposition (Shoji et al. 1993, Torn et al. 1997).

\subsubsection{Climate}

The climate of Ecuador is complex and heterogeneous, as it is dominated throughout the year by tropical climatic phenomena such as the Intertropical Convergence Zone (ITCZ), the Atlantic tradewind system (easterlies) and the El Niño Southern Oscillation (ENSO), as well as local climatic patterns caused by the varying topography of the Andes (e.g. warm moisture-laden air from the Amazon lowland) (Emck 2007, Bendix et al. 2008a, Rollenbeck and Bendix 2011). Generally, the climate is humid, tropical and montane. The Cordillera Real separate the very humid conditions of the Amazon (ca. $8000 \mathrm{~mm} \mathrm{a}^{-1}$ ) from the (semi-) arid Andean basin (ca. $400 \mathrm{~mm} \mathrm{a}^{-1}$ ) (Emck 2007, Bendix et al. 2008b) by the tropical trade wind regime which carries easterly winds laden with moisture across the Amazon basin to the Andes (Bendix et al. 2008b). Within the Andean Depression clouds and fog belts below $3600 \mathrm{~m}$ a.s.l. form frequently and are often persistent leading to increased precipitation (Hansen et al. 2003, Bendix et al. 2004). Generally, precipitation patterns are very irregular and complex, due to the interaction of different cloud systems, regional mountain/valley breeze systems and terrain-lines of favored moisture transport (Rollenbeck and Bendix 2011) (Fig 3).

\section{a. El Cristal (Protective Forest Corazón de Oro)}

The climatic conditions of the Protective Forest Corazón de Oro present an average rainfall rate between ca. 1000 to $2600 \mathrm{~mm} \mathrm{a}^{-1}$, where the driest months are October and November. The mean 
annual temperature changes along the altitudinal gradient varying between 14 to $23{ }^{\circ} \mathrm{C}$ from ca. 1360 to $3400 \mathrm{~m}$ a.s.I. (UNL et al. 2006).

\section{b. Cajanuma valley (Podocarpus National Park)}

The climatic conditions of the Podocarpus National Park present an average annual rainfall rate up to $6000 \mathrm{~mm} \mathrm{a}^{-1}$ (Emck 2007, Moser et al. 2007, Bendix et al. 2008b). Mean annual air temperatures change along the altitudinal gradient from $6-25{ }^{\circ} \mathrm{C}$, from ca. 900 to $3600 \mathrm{~m}$ a.s.l. (Richter 2003).

\section{c. Laguna de Anteojos (Llanganates National Park)}

The climatic conditions of the Llanganates National Park present mean annual precipitation between 1000 to $4000 \mathrm{~mm}$. The driest months are between October to March. The mean annual temperatures varied between 3 and $24{ }^{\circ} \mathrm{C}$ along the altitudinal gradient from ca. 1200 to $4638 \mathrm{~m}$ a.s.l. (Vargas et al. 2000).

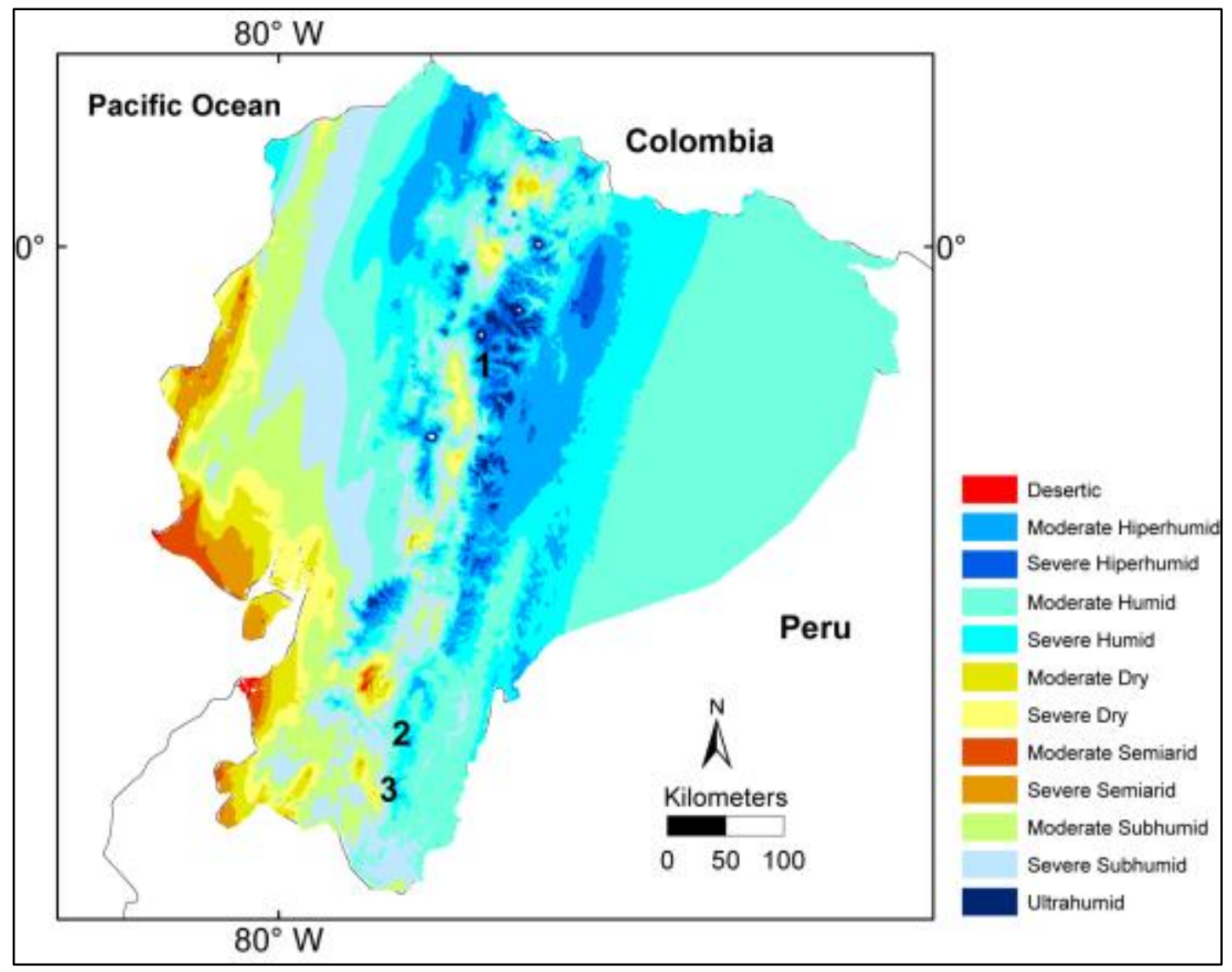

Figure 3. Map of Ecuadorian Andes showing the different climates. 


\subsubsection{Vegetation}

It is estimated that in Ecuador, due to the altitudinal gradient and complex climatic conditions, there are more than 20,000 species of vascular plants and a large number of various vegetation types (Sierra, 1999). In the Protective Forest Corazón de Oro ca. 52 endemic species of vascular plants can be found (UNL et al. 2006). The Podocarpus National Park has almost 4000 vascular plant species (Madsen 1989), and in the Llanganates National Park more than 800 vascular plant species are reported (Vargas et al. 2000). Amongst other descriptions the more appropriate and accurate classifications of natural vegetation types within the study regions are the ones from Homeier et al. (2008), Lozano et al. (2003) for the southern Ecuador and Vargas et al. (2000) and León-Yanez (personal communication 2010) for central Ecuador (Fig 4).

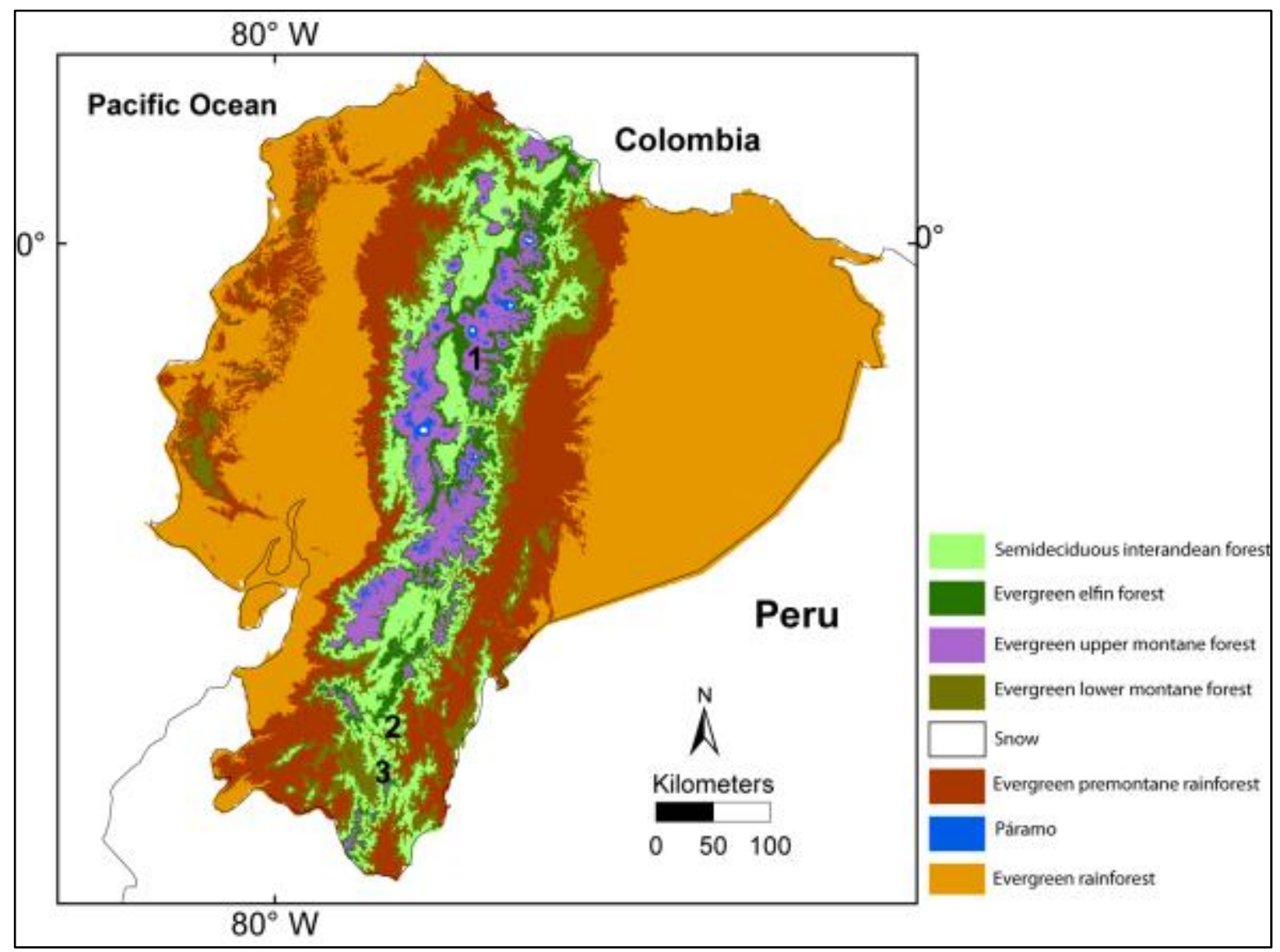

Figure 4. Map of Ecuador showing the diffente vegetation types. 


\section{a. Lower Mountain Forest (LMF)}

The lower mountain forest can be seen on increasing terrain heights of the eastern and western escarpments, between ca. 1500 and 2000 m a.s.l. (southern Ecuador) and ca. 1300 to $2000 \mathrm{~m}$ a.s.l. (central and northern Ecuador). Trees are characterized by height up to $30 \mathrm{~m}$. Common taxa are: Alchornea glandulosa, Piptocoma discolor, Acalypha sp., Hyeronima macrocarpa, Vismia tomentosa, Miconia imitans, Cedrela montana, Ficus sp., Piper sp. and Celtis iguanaea.

\section{b. Upper Mountain Forest (UMF)}

The upper mountain forest starts on increasing terrain heights on the eastern and western escarpments, between ca. 2000 to $2700 \mathrm{~m}$ a.s.l. (southern Ecuador) and ca. 2900 to $3600 \mathrm{~m}$ a.s.l. (central and northern Ecuador); and forms the upper forest line. Trees are characterized by lower height of ca. 6-8 m. Characteristic taxa are: Hedyosmum sp, Weinmannia pinnata, Purdiaea nutans, Clethra revoluta, Clusia elliptica, Graffenrieda emarginata, Tibouchina lepidota, Heliocarpus americanus, Myrica pubescens, Myrsine andina, Podocarpus oleifolius and Prumnopitys montana, and Schefflera pentandra.

\section{c. Subpáramo}

The subpáramo is located at altitudes between 2700 to $3100 \mathrm{~m}$ a.s.I. (southern Ecuador), is characterized by a discontinuous coverage of shrubs and small trees (ca. $2 \mathrm{~m}$ height), such as Miconia ligustrina, Gynoxis cuicochensis, Baccharis genistelloides, Chuquiraga jussieui, Diplostephium empetrifolium and some species of the genus Brachyotum, Escallonia and Hesperomeles.

\section{d. Páramo}

The páramo occurs above the upper forest line between 3100 and $3400 \mathrm{~m}$ a.s.l. (southern Ecuador) and between 3600 and $5000 \mathrm{~m}$ a.s.l. (central and northern Ecuador). The Páramo vegetation is characterized by plants with a maximum height of $2 \mathrm{~m}$. Characteristic taxa are: Arcytophyllum setosum, Blechnum cordatum, Calamagrostis macrophylla, Chusquea neurophylla, Gynoxis buxifolia, Halenia weddelliana, Huperzia kuesteri, Ilex andicola, Monnina arbuscula, Neurolepis nana, Niphogeton dissecta, Oxalis spiralis, Puya eryngioides, Puya maculata, Rhynchospora vulcani, Valeriana microphylla and Weinmannia rollottii. 


\subsubsection{Upper forest line}

The Upper Forest Line (UFL) is defined as the maximum elevation where continuous forest occurs (Bakker et al. 2008). In the southern Ecuadorian Andes (Andean Depression) the UFL is highly variable and not well defined as in the central and northern Ecuadorian Andes (above the Andean Depression), where it occurs at ca. $3600 \mathrm{~m}$ a.s.l. (Richter et al. 2008, Moscol Oliveira and Hooghiemstra 2010). In the Andean Depression the UFL can be seen between 2800 and $3300 \mathrm{~m}$ a.s.I. (Richter and Moreira-Muñoz 2005, Beck et al. 2008).

\subsubsection{Human settlements}

Human activities strongly impacted the vegetation of the Ecuadorian Andes (Ramsay and Oxley 1996), as a consequence of the long-term occupation of this region which effectively started from ca. 2000 years ago (e.g. Bellwood 2005). During the pre-Columbian times a long-lasting deforestation in the mountain regions had contributed to the reduction of forest areas (Wunder 2000). In the last century the open vegetation became increasingly converted into agricultural land (Dodson and Gentry 1991, Pohle 2008).

Early human interaction with the landscape is reported from various sites throughout the Ecuadorian Andes; e.g. the archaeological site El Inga (near Quito) recorded the presence of human settlements at 11,000 yr BP (Mayer-Oakes 1986) and Cubilán, ca. 100 km north of Loja, recorded scant traces of hunter-gatherers, nomads or semi-nomads populations at 10,000 cal yr BP (Temme 1982). The first clear human driven change in the landscape in the region of Loja and Zamora is dated back to ca. $4000 \mathrm{cal}$ yr BP; although human may have been active in the dry InterAndean valley much earlier (Guffroy 2004).

\subsection{General methods of pollen analysis}

\subsubsection{Field work: coring of sediments samples}

Palynological studies are carried out on sediments cores taken mainly from small lakes, lagoon or peat bogs, and for every coring site different coring methods and devices are often employed. In this study, three sediment cores were taken from three different peat bogs for palynological analysis. To extract the sediment cores, the Russian corer was used to drill out column sections of $5 \mathrm{~cm}$ diameter and $50 \mathrm{~cm}$ length. The sediment cores were wrapped in plastic film and protected by splitted PVC tubes. The sediments samples were kept in dark and cold $\left(+4^{\circ} \mathrm{C}\right)$ conditions, before 
processing in order to minimize oxidation, drying, fungal contamination and lights effect. The El Cristal and Cajanuma valley sediment cores were kept at the Department of Palynology and climate Dynamics at the University of Göttingen (Germany) and the Anteojos valley sediment core at the Pontificia Universidad Católica Quito-Ecuador.

\subsubsection{Laboratory work: processing of sediments samples}

Along all the sediment cores, subsamples of $0.50 \mathrm{~cm}^{3}$ were taken at $4 \mathrm{~cm}$ intervals using metal cylinders samplers, since the initial sample volume is very important for calculations of important values such as concentration and accumulation rates of pollen and spore. All subsamples were processed using the standard pretreatment after Fægri and Iversen (1989) in order to remove the large amount of organic and inorganic material. First, to calculate concentration and influx, one tablet of Lycopodium clavatum spores was added to every subsample (each tablet contains 18583 \pm 762 for El Cristal and Cajanuma valley and $20848 \pm 1546$ for Anteojos valley) and dissolved with a solution of $10 \%$ Hydrochloric acid $(\mathrm{HCl})$, which also removes larger carbonated particles. Then, subsamples were treated with a solution of $72 \%$ hydrofluoric acid (HF), for 24 hours, in order to remove silicates. By using a mesh of $150 \mu \mathrm{m}$ size, the subsamples were sieved and filtered to remove large particles. Afterwards, the subsamples were dehydrated with acetic acid $\left(\mathrm{CH}_{3} \mathrm{COOH}\right)$ before treatment with the Erdman acetolysis. The acetolysis is used to remove the cellulose, clear the exine and colored the pollen and spore grains. First step in the acetolysis process is to add to each sample a 9:1 mixture of acetic anhydride $\left(\mathrm{CH}_{3} \mathrm{CO}\right)_{2} \mathrm{O}$ and concentrated sulphuric acid $\left(\mathrm{H}_{2} \mathrm{SO}_{4}\right)$ for 10 minutes in a water bath at $90^{\circ} \mathrm{C}$. Finally, the subsamples were mounted onto slides with a glycerin gelatin medium. The slides were analyzed under a Zeiss Axiostar Plus microscope at a magnification of $400 x$ and for critical identifications $1000 x$.

\subsubsection{Radiocarbon dating}

In order to link the palynological records to a time scale and compare the records chronologically, the development of a stratigraphic age-depth relationship is required. Therefore, radiocarbon dating technique measuring the unstable carbon isotope $14\left({ }^{14} \mathrm{C}\right)$ were used. The age-depth models are constructed after calibrating radiocarbon dates.

In total 14 samples (soil organic material and charcoal) were submitted to radiocarbon dating after having them cleaned from fresh roots to avoid contamination of younger organic material (Table 
1). All samples were dated using accelerator mass spectrometry (AMS) ${ }^{14} \mathrm{C}$ radiocarbon dating at the University of Erlangen/Nürnberg, (Germany). The radiocarbon dates were calibrated using the curve CalPal 2007 HULU for the northern hemisphere included in the CalPal software (Weninger et al. 2004) or the curve SHCal04 ${ }^{14} \mathrm{C} \mathrm{SH}$ terrestrial dataset of the Calib 6.0 software (Stuiver et al. 2005).

Table 1. List of AMS radiocarbon ${ }^{14} \mathrm{C}$ dates and calibrated ages from the three different analyzed cores using the he curve CalPal 2007 HULU of the CalPal software or the curve SHCal04 ${ }^{14} \mathrm{C} \mathrm{SH}$ terrestrial dataset of the Calib 6.0 software.

\begin{tabular}{llllll}
\hline Core name & Lab. Code & Dated material & Depth $(\mathbf{c m})$ & ${ }^{14}$ C yr BP & 1- $\boldsymbol{\sigma}$ (cal yr BP) \\
\hline El Cristal & Erl-16584 & Org. material & $45-46$ & $346 \pm 50$ & $404 \pm 65$ \\
El Cristal & Erl-16084 & Org. material & $95-96$ & $1927 \pm 41$ & $1780 \pm 224$ \\
El Cristal & Erl-16083 & Charcoal & $132-133$ & $3527 \pm 45$ & $3743 \pm 128$ \\
El Cristal & Erl-16977 & Org. material & $141-142$ & $4335 \pm 50$ & $4923 \pm 55$ \\
El Cristal & Erl-16976 & Org. material & $153-154$ & $11318 \pm 84$ & $13221 \pm 123$ \\
El Cristal & Erl-16585 & Org. material & $166-168$ & $14928 \pm 123$ & $18214 \pm 254$ \\
Cajanuma valley & Erl-16087 & Org. material & $80-81$ & $378 \pm 48$ & $402 \pm 90$ \\
Cajanuma valley & Erl-16586 & Org. material & $104-105$ & $1538 \pm 107$ & $1396 \pm 218$ \\
Cajanuma valley & Erl-16086 & Org. material & $135.5-136.5$ & $4803 \pm 66$ & $5515 \pm 82$ \\
Cajanuma valley & Erl-16587 & Wood & $160-161$ & $9933 \pm 86$ & $11440 \pm 153$ \\
Anteojos valley & Erl-16076 & Org. material & $99-100$ & $265 \pm 48$ & $184 \pm 34$ \\
Anteojos valley & Erl-16077 & Org. material & $199-200$ & $1296 \pm 57$ & $1171 \pm 117$ \\
Anteojos valley & Erl-16078 & Org. material & $299-300$ & $2598 \pm 58$ & $2606 \pm 154$ \\
Anteojos valley & Erl-16079 & Org. material & $399-400$ & $3782 \pm 95$ & $4100 \pm 258$ \\
\hline
\end{tabular}

\subsubsection{Pollen and spore identification}

Pollen grains of different groups of plants have different shapes, and by using diagnostic features they can be identify to a certain taxonomic level under the microscope (Fægri and Iversen 1950). Identification of pollen grains in the tropical regions is a hard and challenging task, due to the high diversity of vascular and non-vascular plants that produced the pollen grains. Therefore, is of major importance to have a good reference collection in order to increase the level of 
identification. In this study pollen identification relied on the pollen morphological guide of Hooghiemstra (1984), the Neotropical database of the Florida Institute of Technology with ca. 3000 different taxa (Bush and Weng 2007) and the Ecuadorian pollen key with ca. 620 Ecuadorian taxa, kept at the University of Göttingen.

A minimum of 300 pollen grains were counted along with pteridohpyta spores, Lycopodium clavatum (marker) and charcoal particles in every analyzed subsample. Among the three sediment cores (El Cristal, Cajanuma valley and Anteojos valley) a total of 83 pollen types were identified and a total of 15 morphotypes of pteridophyta spores were identified (Table 2) (Appendix 1 and 2)

Table2. Identified pollen and spores of the three different pollen records (chapter 2-4)

\begin{tabular}{llll}
\hline Pollen record & Pollen types & Spores types & No. of subsamples \\
\hline El Cristal & 67 & 13 & 41 \\
Cajanuma valley & 78 & 14 & 41 \\
Anteojos valley & 66 & 14 & 89 \\
\hline
\end{tabular}

\subsubsection{Data calculation and visualization}

Palynological data are elaborated and presented using the software programs TILIA, TILIAGRAPH and CONISS software (Grimm 1987). In order to reconstruct the changes in vegetation composition, the pollen data were divided into vegetation types according to the different ecological group. The most significant and important taxa were selected to be included in the pollen diagram and for further interpretation. The traditional pollen diagram is the most efficient way to present pollen and spore compositional results. In addition, the diagrams include radiocarbon dates (uncal yr BP), the age scale (cal yr BP), the stratigraphy, pollen and spores grouped into ecological groups, pollen sums, pollen and charcoal concentrations and influxes, and the CONISS dendrogram. In this study, pollen taxa were divided following the classification of Homeier et al. (2008), Vargas et al. (2000) and León-Yánez (personal communication 2010) in lower mountain forest (LMF), upper mountain forest (UMF), subpáramo and páramo (Appendix 3).

\subsection{General objectives and outline of the chapters}

The principal goal of this investigation is to increase the knowledge on the late Quaternary palaeoenvironmental conditions in the central and southern Ecuadorian Andes. As these regions 
are part of one of the five most species-rich biodiverse hot-spots in the world (Myers et al. 2000) reconstructing the past vegetation dynamics, climate changes and human impact since the late Pleistocene for the three different study sites is very important. The studied sites presented in this thesis, provide additional and detailed information on the climatic conditions, the upper forest line dynamics and the effect, timing and intensity of human impact inferred from past vegetation dynamics and charcoal analysis.

In this context, this study aims at answering the following research questions:

- Do different sites in the central and southern Ecuadorian Andes show similar patterns of pollen compositional changes since the last Pleistocene?

- How dynamic or stable was the vegetation since the late Pleistocene in the central and southern Ecuadorian Andes?

- Has fire, natural or anthropogenic, played an important role on the vegetation dynamics since the late Pleistocene?

- When did the human impact start, and how strong was the human impact in the central and southern Ecuadorian Andes during the past?

\subsubsection{Chapter structure}

The chapters are presented in sequential order and were prepared as manuscripts for publication in peer-reviewed scientific international journals. The content of each chapter is summarized below.

\section{a. Chapter II}

The pollen analysis of the El Cristal record provides a detailed history of the vegetation and fire dynamics since the late Pleistocene. In particular, it provides evidence for Polylepis woodland in the region during the late Pleistocene, which cannot be seen anymore today.

\section{b. Chapter III}

The pollen record of Cajanuma valley located in the southwestern Podocarpus National Park provides a detail reconstruction of the environmental history including vegetation, fire and climate 
dynamics since the late Glacial. A comparison between the pollen analyses in the Podocarpus National Park conveys a comprehensive overview of the late Glacial and the Holocene environment.

\section{c. Chapter IV}

The pollen analysis of the El Cristal record is one of the few palaeoecological sites from the central eastern Ecuadorian Andes. Pollen and charcoal analysis shows at high resolution the vegetation and environmental dynamics since the mid-Holocene. In particular, it provides evidence of human impact since 760 cal yr BP as indicated by the presence of the pollen grain of Zea mays.

\section{d. Chapter V}

This chapter contains the synthesis of the palaeoecological research; based on multiple proxies analysis (pollen, spores, charcoal analyses and radiocarbon dating) of the three different sediments cores El Cristal, Cajanuma valley and Anteojos valley since the late Pleistocene. Late Pleistocene vegetation, climate dynamics, fire history and human impact are here discussed and synthesized.

Appendix A: A list of identified pollen and spores taxa grouped into the four major vegetation types.

Appendix B: Pollen and spores photo plates for the most common identified taxa with a short description.

Appendix C: Complete palynological diagrams of identified pollen grains and spores for the three cores.

\subsection{References}

Abbott, M., B. Wolfe, A. Wolfe, G. Seltzer, R. Aravena, B. Mark, P. Polissar, D. Rodbell, H. Rowe, and M. Vuille. 2003. Holocene paleohydrology and glacial history of the central Andes using multiproxy lake sediment studies. Palaeogeography, Palaeoclimatology, Palaeoecology 194:123-138.

Aspden, J., and M. Litherland. The geology and Mesozoic collisional history of the Cordillera Real, Ecuador. Tectonophysics 205: 187-204.

Baker, P.A., G.O. Seltzer, S.C. Fritz, R.B. Dunbar, M.J. Grove, P.M. Tapia, S.L. Cross, H.D. Rowe, and J.P. Broda. 2001. The History of South American Tropical Precipitation for the Past 25,000 Years. Science 291: 640-643. 
Bakker, J., M. Moscol Olivera, and H. Hooghiemstra. 2008. Holocene environmental change at the upper forest line in northern Ecuador. The Holocene 18: 1-17.

Balslev, H. 1988. Distribution patterns of Ecuadorean plant species. Taxon 37: 567-577.

Barthlott, W., A. Hostert, G. Kier,W. Küper, H. Kreft, J. Mutke,M.D. Rafiqpoor and J.H., Sommer. 2007. Geographic patterns of vascular plant diversity at continental to global scales. Erdkunde 61: 305-315.

Beck, E., F. Makeschin, F. Haubrich, M. Richter, J. Bendix, and C. Valerezo. 2008. The Ecosystem (Reserva Biológica San Francisco). In: Beck, E., Bendix, J., Kottke, I., Makeschin, F., Mosandl, R. (Eds.), 2008a. Gradients in a Tropical Mountain Ecosystem of Ecuador. Ecological Studies 198. Springer, Berlin, Heidelberg, pp. 1-13.

Bellwood, P. 2005. First farmers. The origins of agricultural societies. Blackwell Malden. Mass, USA. $360 \mathrm{pp}$.

Bendix, J., R. Rollenbeck, and W. E. Palacios. 2004. Cloud detection in the Tropics - a suitable tool for climate---ecological studies in the high mountains of Ecuador. International Journal of Remote Sensing 25: 4521-4540.

Bendix, J., R. Rollenbeck, P. Fabian, P. Emck, M. Richter, and E. Beck. 2008a. Climate variability. Pages 281-290 in E. Beck, J. Bendix, I. Kottke, F. Makeschin, and R. Mosandl, editors. Gradients in a tropical mountain ecosystem of Ecuador. Springer, Berlin.

Bendix, J., R. Rollenbeck, M. Richter, P. Fabian, and P. Emck. 2008b. Climate. Pages 63-73 in E. Beck, J. Bendix, I. Kottke, F. Makeschin, and R. Mosandl, editors. Gradients in a tropical mountain ecosystem of Ecuador. Springer, Berlin.

Brunschön, C. and H. Behling. 2009. Late Quaternary vegetation, fire and climate history reconstructed from two cores at Cerro Toledo, Podocarpus National Park, southeastern Ecuadorian Andes. Quaternary Research 72: 388-399.

Brunschön, C. and H. Behling. 2010. Reconstruction and visualization of upper forest line and vegetation changes in the Andean depression region of southeastern Ecuador since the last glacial maximum - A multi-site synthesis. Review of Palaeobotany and Palynology 163: 139-152.

Brunschön, C., Haberzettl, T. and H. Behling. 2010. High-resolution studies on vegetation succession, hydrological variations, anthropogenic impact and genesis of a subrecent lake in southern Ecuador. Vegetation History and Archaeobotany 19: 191-206.

Bush, M.B. and W.D. Gosling. 2012. Environmental Change in the Humid Tropics and Monsoonal Regions. Pp. 113-140 in Matthews, J.A., Bartlein, P.J., Briffa, K.R., Dawson, A.G., de Vernal, A., Denham, T., Fritz, S.C. \& F. Oldfield (eds.). The SAGE Handbook of Environmental Change. SAGE, London.

Bush, M.B. and C. Weng. 2007. Introducing a new (freeware) tool for palynology. Journal of Biogeography 34: 377-380.

Bush, M.B., B.C.S. Hansen, D.T. Rodbell, G.O. Seltzer, K.R. Young, B. Leon, M.B. Abbott, M.R. Silman, and W.D. Gosling. 2005. A 17 000-year history of Andean climate and vegetation change from Laguna de Chochos, Peru. Journal of Quaternary Science 20: 703-714.

Bush, M.B., J.A. Hanselman, and H. Hoogheimstra, H. 2011. Andean montane forests and climate change. In: Bush, M.B., Flenley, J.R., Gosling, W.D. (Eds.), Tropical Rainforest Responses to Climatic Change, second ed. Springer Praxis, Chichester, pp. 35-60.

Buytaert, W., J. Sevink, B. Deleeuw, and J. Deckers. 2005. Clay mineralogy of the soils in the south Ecuadorian páramo region. Geoderma 127:114-129.

Clapperton, C.M, M. Hall, P. Mothers, M.J. Hole, J.W. Still, K.F. Helmens, P. Kuhry, and A.M.D. Gemmell. 1997. A Younger Dryas ice cap in the equatorial Andes. Quaternary Research 47: 13-28. 
Colinvaux P., K. Olson, and K.B. Liu. 1988. Late-glacial and Holocene pollen diagrams from two endorheic lakes of the Inter-Andean plateau of Ecuador. Review of Palaeobotany and Palynology 55: 83-99.

Colinvaux, P.A., M.B. Bush, M. Steinitz-Kannan, and M.C. Miller. 1997. Glacial and postglacial pollen records from the Ecuadorian Andes and Amazon. Quaternary Research 48: 69-78.

Di Pasquale G, M. Marziano, S. Impagliazzo, C. Lubritto, A. De Natale, and M.Y. Bader. 2008. The Holocene treeline in the northern Andes (Ecuador): First evidence from soil charcoal. Palaeogeography, Palaeoclimatology, Palaeoecology 259: 17-34.

Dodson C, and A.H. Gentry. 1991. Biological extinction in western Ecuador. Annals of the Missouri Botanical Garden 78: 273-295.

Emck P. 2007. A Climatology of South Ecuador - With Special Focus on the Major Andean Ridge as Atlantic- Pacific climate Divide. Dissertation, Universität Erlangen, Nürnberg.

Fægri, K., and J. Iversen. 1950. Text---book of modern pollen analysis. Ejnar Munksgaard, Copenhagen.

Fægri K, Iversen J. 1989. Textbook of Pollen Analysis, 4th ed. Wiley, Chichester.

Gómez, A., J.-C. Berrío, H. Hooghiemstra, M. Becerra, and R. Marchant. 2007. A Holocene pollen record of vegetation change and human impact from Pantano de Vargas, an intra-Andean basin of Duitama, Colombia. Review of Palaeobotany and Palynology 145:143-157.

Grimm, E.C. 1987. CONISS: a Fortran 77 program for stratigraphically constrained cluster analysis by the method of the incremental sum of squares. Computer and Geosciences 13: 13-35.

Guffroy, J. 2004. Catamayo precolombino. Investigaciones arqueológicas en la provincia de Loja (Ecuador). IRD editions, Paris.

Hall, M.L., P. Samaniego, J.L. Le Pennec and J.B. Johnson. 2008. Ecuadorian Andes volcanism: A review of Late Pliocene to present activity. Journal of Volcanology and Geothermal Research 176: 1-6.

Hansen, B.C.S., G.O. Seltzer, and H.E. Wright. 1994. Late Quaternary vegetation change in the central Peruvian Andes. Palaeogeography, Palaeoclimatology, Palaeoecology 109: 263285.

Hansen B.C.S., and D.T. Rodbell. 1995. A Late-Glacial/Holocene pollen record from the eastern Andes of northern Peru. Quaternary Research 44: 216-227.

Hansen, B.C.S., D.T. Rodbell, G.O. Seltzer, B. León, K.R. Young, and M. Abbott. 2003. Late-glacial and Holocene vegetation history from two sides in the western Cordillera of southwestern Ecuador. Palaeogeography, Palaeoclimatology, Palaeoecology 194: 79-108.

Homeier, J., F.A. Werner, S.R., Gradstein, S.W., Breckle, and M. Richter. 2008. Potential vegetation and floristic composition of Andean forests in South Ecuador, with a focus on the RBSF. Pp. 87-100 in Beck, E., Bendix, J., Kottke, I., Makeschin, F. and R. Mosandl (eds.). Gradients in a Tropical Mountain Ecosystem of Ecuador. Ecological Studies 198. Springer, Berlin, Heidelberg.

Hooghiemstra H. 1984. Vegetation and Climatic History of the High Plain of Bogota, Colombia: a continuous record of the last 3.5 million years. Dissertationes Botanicae 79. Cramer, Vaduz.

Jantz, N. and H. Behling. 2012. A Holocene environmental record reflecting vegetation, climate, and fire variability at the Páramo of Quimsacocha, southwestern Ecuadorian Andes. Vegetation History and Archaeobotany 21: 169-185.

Jørgensen, P.M., and S. León-Yánez (eds.). 1999. Catalogue of the Vascular Plants of Ecuador. Monogr. Syst. Bot. Missouri Bot. Gard. 75: i-viii, 1-1182.

Jørgensen P.M., C. Ulloa. 1994. Seed Plants of the High Andes of Ecuador-check List. AAU Reports, 34: pp. 1-443. 
Kennerly J.,B. Bromley. 1971. Geology and geomorphology of the Llanganatis mountains, Ecuador. Minerva-Quito

León-Yánez S., R. Valencia, N. Pitman, L. Endara, C. Ulloa, and H. Navarrete (eds.). 2011. Libro rojo de las plantas endémicas del Ecuador, 2a. ed., Publicaciones del Herbario QCA. Pontificia Universidad Católica del Ecuador.

Liess, M., B. Glaser, and B. Huwe. 2009. Digital soil mapping in southern Ecuador. ERDKUNDE 63:309-319.

Lozano, P., T. Delgado, Z. Aguirre. 2003. Estado actual de la flora endémica exclusive y su distribucion en el Occidente del Parque Nacional Podocarpus. Funbotanica y Herbario y Jardin Botanico. Loja, Ecuador.

Madsen, J.E. 1989. Aspectos generales de flora y vegetación del Parque Nacional Podocarpus. Universidad Nacional de Loja. Loja

Marchant, R., H. Behling, J.-C. Berrio, A. Cleef, J. Duivenvoorden, H. Hooghiemstra, P. Kuhry, B. Melief, E. Schreve-Brinkman, B. Van Geel, T. Van der Hammen, G. Van Reenen, and M. Wille. 2002. Pollen-based biome reconstructions for Colombia at 3000, 6000, 9000, 12 000, 15000 and $1800014 \mathrm{C}$ yr ago: Late Quaternary tropical vegetation dynamics. Journal of Quaternary Science 17:113-129.

Mayer-Oakes, W. 1986. El Inga, a Paleo-Indian site in the Sierra of Northern Ecuador. Transactions of the American Philosphical Society 76:1-235.

Mosandl R., S. Günter, B. Stimm, and M. Weber. 2008. Ecuador suffers the Highest Deforestation Rate in South America. In: Beck, E., Bendix, J., Kottke, I., Makeschin, F., Mosandl, R. (Eds.), Gradients in a Tropical Mountain Ecosystem of Ecuador. Ecological Studies vol. 198, Springer, Berlin, Heidelberg, pp. 37-40.

Moscol Oliveira, M., and H. Hooghiemstra. 2010. Three millennia upper forest line changes in northern Ecuador: Pollen records and altitudinal vegetation distributions. Review of Palaeobotany and Palynology 163: 113-126.

Moser, G., D. Hertel, and C. Leuschner. 2007. Altitudinal Change in LAI and Stand Leaf Biomass in Tropical Montane Forests: a Transect Study in Ecuador and a Pan-Tropical Meta-Analysis. Ecosystems 10:924-935.

Mutke, J. and W. Barthlott. 2005. Patterns of vascular plant diversity at continental to global scales. Biologiske Skrifter 55: 521-531.

Mutke, J., J. Sommer, H. Kreft, G. Kier, and W. Barthlott. 2011. Vascular Plant Diversity in a Changing World: Global Centres and Biome-Specific Patterns. Pages 83-96 in F. E. Zachos and J. C. Habel, editors. Biodiversity Hotspots. Springer Berlin Heidelberg, Berlin, Heidelberg.

Myers, N., R. Mittermeier, C. Mittermeier, G. da Fonseca, and J. Kent. 2000. Biodiversity hotspots for conservation priorities. Nature 403:853-858.

Niemann, H., and H. Behling. 2008. Late Quaternary vegetation, climate and fire dynamics inferred from the El Tiro record in the southeastern Ecuadorian Andes. Journal of Quaternary Science 23:203-212.

Niemann, H., and H. Behling. 2009. Late Pleistocene and Holocene environmental change inferred from the Cocha Caranga sediment and soil records in the southeastern Ecuadorian Andes. Palaeogeography, Palaeoclimatology, Palaeoecology 276:1-14.

Niemann H., and H. Behling. 2010. Late Holocene environmental change and human impact inferred from three soil monoliths and the Laguna Zurita multi-proxi record in the southeastern Ecuadorian Andes. Vegetation History and Archaeobotany 19: 1-15. 
Niemann H., T. Haberzettl, and H. Behling. 2009. Holocene climate variability and vegetation dynamics inferred from the (11,700 cal yr BP) Laguna Rabadilla de Vaca sediment record in the southeastern Ecuadorian Andes. The Holocene 19: 307-316.

Niemann H., I. Matthias, B. Michalzik, and H. Behling. 2013. Late Holocene human impact and environmental change inferred from a multi-proxy lake sediment record in the Loja region, southeastern Ecuador. Quaternary International. http://dx.doi.org/10.1016/i.quaint. 2013.05.22

Paduano, G.M., M.B. Bush, P.A. Baker, S.C. Fritz, and G.O. Seltzer. 2003. A vegetation and fire history of Lake Titicaca since the Last Glacial Maximum. Palaeogeography, Palaeoclimatology, Palaeoecology 194: 259-279.

Podwojewski, P., Poulenard, J., Zambrana, T. and R. Hofstede. 2006. Overgrazing effects on vegetation cover and properties of volcanic ash soil in the páramo of Llangahua and La Esperanza (Tungurahua, Ecuador). Soil Use Management 18: 45-55.

Pohle P. 2008. The people settled around Podocarpus National Park. In: Beck E, Bendix J, Kottke I, Makeschin F, Mosandl R (eds) Gradients in a tropical mountain ecosystem of Ecuador. Ecol Stud 198. Springer Verlag, Berlin, Heidelberg, pp 25-36

Ramsay P.M., and E. Oxley. 1996. Fire temperatures and postfire plant community dynamics in Ecuadorian grass Páramo. Vegetation 124: 129-144.

Richter, M. 2003. Using epiphytes and soil temperature for eco-climatic interpretations in south Ecuador. Erdkunde 57, 161-181.

Richter, M. and A. Moreira-Muñoz. 2005. Climatic heterogeneity and vegetation diversity in southern Ecuador investigated by phytoindication. Review of Peruvian Biology 12: 217238.

Richter, M., K.-H. Diertl, T. Peters, and R. Bussmann. 2008. Vegetation Structures and Ecological Features of the Upper Timberline Econtone. Pages 123-136 in E. Beck, J. Bendix, I. Kottke, F. Makeschin, and R. Mosandl, editors. Gradients in a tropical mountain ecosystem of Ecuador. Springer, Berlin.

Rodbell, D.T., and G.O. Seltzer. 2000. Rapid ice margin fluctuations during the Younger Dryas in the tropical Andes. Quaternary Research 54: 328-338.

Rodbell D.T., S. Bagnato, J.C. Nebolini, G.O. Seltzer, and M.B. Abbott. 2002. A late Glacial-Holocene Tephrochronology for Glacial Lakes in Southern Ecuador. Quatenary Research 57: 343-354.

Rodríguez, F. and H. Behling, H. 2011. Late Holocene vegetation, fire, climate and upper forest line dynamics in the Podocarpus National Park, southeastern Ecuador. Vegetation History and Archaeobotany 20: 1-14.

Rollenbeck, R., and J. Bendix. 2011. Rainfall distribution in the Andes of southern Ecuador derived from blending weather radar data and meteorological field observations. Atmospheric Research 99:277-289.

Schubert, C., C.M. Clapperton. 1990. Quaternary glaciations in the Northern Andes (Venezuela, Colombia and Ecuador). Quaternary Science Reviews 9: 123-135.

Shoji S.M., M. Nanzyo, and R.A. Dahlgren. 1993. Volcanic Ash Soils: Genesis, Properties and Utilization. New York: Elsevier. 288 p.

Sierra, R. (Ed.). 1999. Propuesta preliminar de un sistema de clasificación de vegetación para el Ecuador continental. Proyecto INEFAN/GEF-BIRF y EcoCiencia. Quito, Ecuador

Silverman, H., and W.H. Isbell (Eds.), 2008. Handbook of South American Archaeology. Springer, New York, 1199 pp.

Stuiver M., P.J. Reimer, and R.W. Reimer. 2005. CALIB 6.0. Radiocarbon Calibration Program. URL: http://calib.qub.ac.uk/calib/calib.html 
Temme, M. 1982. Excavaciones en el sitio precerámico de Cubilan (Ecuador). Miscelánea Antropológica Ecuatoriana 2: 135-165.

Torn M.S.S., S.E. Trumbore, O.A. Chadwick, P.M. Vitousek and D.M. Hendricks. 1997. Mineral control of soil organic carbon storage and turnover. Nature 389(6647):170-3.

UNL (Universidad Nacional de Loja), CINFA (Centro Integrado de Geomática Ambiental) and Herbario Reinaldo Espinosa. 2006. Estado de Conservación del Área de Bosque y Vegetación Protectora "Corazón de Oro", Loja.

Urrego, D.H., B.A. Niccum, C.F. La Drew, M.R. Silman, and M.B. Bush. 2011. Fire and drought as drivers of early Holocene tree line changes in the Peruvian Andes. Journal of Quaternary Science 26: 28-36.

Valencia, B.G., D.H. Urrego, M.R. Silman, and M.B. Bush. 2010. From ice age to modern: a record of landscape change in an Andean cloud forest. Journal of Biogeography 37: 1637-1647.

Van der Hammen, T., and H. Hooghiemstra. 2003. Interglacialeglacial Fuquene-3 pollen record from Colombia: an Eemian to Holocene climate record. Global and Planetary Change 36: 181-199.

Van der Hammen T., G. Noldus, and E. Salazar. 2003. Un diagrama de polen del Pleistoceno final y Holoceno de Mullumica. Maguaré 17: 247-259.

Vargas H., D. Neill, M. Asanza, A. Freire-Fierro, and E. Narváez. 2000. Vegetación y flora del Parque Nacional Llanganates. En: Vázquez, M.A. y M. Larrea (Eds.). Biodiversidad en el Parque Nacional Llanganates: un reporte de las evaluaciones ecológicas y socioeconómicas rápidas. EcoCiencia, Herbario Nacional del Ecuador, Museo Ecuatoriano de Ciencias Naturales e Instituto Internacional de Reconstrucción Rural. Quito.

Vélez M.I, H. Hooghiemstra, S. Metcalfe, M. Wille, and J.C. Berrío. 2006. Late Glacial and Holocene environmental and climatic changes from a limnological transect through Colombia, northern South America. Palaeogeography, Palaeoclimatology, Palaeoecology 234: 81-96.

Villota A., and H. Behling. 2013. Late quaternary vegetation, climate, and fire dynamics: human impact and evidence of past Polylepis populations in the northern Andean Depression inferred from the el Cristal record in Southeastern Ecuador. Ecotropica 19: 39-58.

Villota A., S. León-Yánez, and H. Behling. 2012. Vegetation and environmental dynamics in the Páramo of Jimbura region in the southeastern Ecuadorian Andes during the late Quaternary. Journal of South American Earth Sciences 40: 85-93.

Weigend, M. 2002. Observations on the Biogeography of the Amotape-Huancabamba Zone in Northern Peru. The Botanical Review 68:38-54.

Weng, C., M. Bush, J. Curtis, A. Kolata, T. Dillehay, and M. Binford. 2006. Deglaciation and Holocene climate change in the western Peruvian Andes. Quaternary Research 66:87-96.

Weninger, B., O. Jöris, and U. Danzeglocke. 2004. Calpal: The Cologne Radiocarbon Calibration and Palaeoclimate Research Package. URL: www.calpal.de.

Wille, M., H. Hooghiemstra, H. Behling, K. van der Borg, and A.J. Negret. 2001. Environmental change in the Colombian subandean forest belt from 8 pollen records: the last $50 \mathrm{kyr}$. Vegetation History and Archaebotany 10: 61-77.

Wille, M., H. Hooghiemstra, R. Hofstede, J. Fehse, and J. Sevink. 2002. Upper forest line reconstruction in a deforested area in northern Ecuador based on pollen and vegetation analysis. Journal of Tropical Ecology 18: 409-440.

Wunder, S. 2000. The economics of deforestation: the example of Ecuador. St. Martin, New York. 



\title{
CHAPTER 2
}

Late Quaternary vegetation, climate, and fire dynamics: human impact and evidence of past Polylepis populations in the northern Andean Depression inferred from the El Cristal record in southeastern Ecuador

\author{
Andrea Villota $^{1,2}$ \& Hermann Behling ${ }^{2}$ \\ ${ }^{1}$ Herbario QCA, Escuela de Ciencias Biológicas, Pontificia Universidad Católica del Ecuador, Quito- \\ Ecuador \\ ${ }^{2}$ Department of Palynology and Climate Dynamics, Albrecht von Haller Institute for Plant \\ Sciences, University of Göttingen, 37073 Göttingen, Germany
}

ECOTROPICA 19 (2013): 39-58 


\section{Abstract}

Late Pleistocene and Holocene vegetation, climate, and fire dynamics, as well as human impact, were studied in the El Cristal region, which is part of the Andean Depression in southeastern Ecuador. The sediment core from a small basin at $2056 \mathrm{~m}$ a.s.l. was analysed by pollen and charcoal analysis and dated by six radiocarbon dates. The record indicates that during the late Pleistocene (ca. 19 750-12 500 cal yr BP) the Upper Mountain Rainforest (UMF), with some smaller areas of páramo and subpáramo were the main vegetation type in the study area. Additionally, there is evidence for Polylepis woodland in the region during this period, which does not exist in the area today. During the transition from the late Pleistocene to the early and midHolocene between ca. 12500 to 3600 cal yr BP, there is a significant presence of mountain rainforest and stable proportions of subpáramo and páramo taxa. The early Holocene from ca. 11 500 to $7800 \mathrm{cal}$ yr BP is characterized by UMF vegetation at the study site. Polylepis became more frequent and reached its maximum. During the mid-Holocene between 7800 to 3600 cal yr BP, the composition of the UMF changed. Polylepis decreased after ca. $4000 \mathrm{cal} \mathrm{yr} \mathrm{BP,} \mathrm{probably} \mathrm{due} \mathrm{to}$ higher fire frequency. During the mid- to late Holocene, human landscape disturbance is evident, especially between ca. 2000 and 1380 cal yr BP, with Asteraceae, Muehlenbeckia/Rumex, Osmunda and Huperzia all increasing in abundance. The late Holocene, from ca. 1380 cal yr BP, was characterized by an increased abundance of páramo taxa and a decrease in mountain rainforest taxa. The expansion of grassland during the late Holocene is interpreted as a result of an increase in human activity, which limited forest vegetation to isolated patches. However, between ca. 1200 and 900 cal yr BP the UMF expanded, probably due to forest recovery after the high frequency of fire. Between ca. 900 cal yr BP to present times, the UMF vegetation decreased markedly and grasslands (páramo taxa) expanded.

\section{Keywords}

Late Pleistocene, Holocene, palynology, páramo, mountain rainforest, fire history, human impact, Polylepis, Andean Depression, southern Ecuador. 


\subsection{Introduction}

The tropical northern Andes are among the hot spots of global vascular plant diversity due to its high structural and geological diversity (Mutke \& Barthlott 2005). Mountain forests in particular contribute to this extraordinarily high level of biodiversity (Richter et al. 2008). According to Webster (1995), half of all species of the flora of Ecuador are found in the mountain rainforests. Despite the significance of these mountain ecosystems in terms of biodiversity, the mountain rainforests of the Ecuadorian Andes represent the most threatened (Myers et al. 2000) and poorly studied habitat (Gentry 1995, Webster 1995, Beck et al. 2008a). Official sources report that of all South American countries, Ecuador currently suffered the highest deforestation rate of 198000 ha year $^{-1}$ between 1990 and 2005 (FAO 2006), because of its long occupation history and increasing human impact during recent decades (Dodson \& Gentry 1991). Even during pre-Columbian times, a long-lasting deforestation in the mountain regions contributed to the reduction of forest areas (Wunder 2000). The páramo vegetation is thought to have expanded downslope, while extensive burning and grazing prevented forest recovery. Some researchers suggest that the grass páramo below $4300-4100$ m represents, at least partially, secondary vegetation in formerly forested areas (Ellenberg 1979, Lægaard 1992). Studies by Podwojewski et al. (2002) suggest that páramo areas, especially at lower altitudes, are subject to overgrazing, fire, or cultivation. In general, human activity has a strong impact on the vegetation of the Ecuadorian Andes, as land use patterns frequently involve grazing, burning, and deforestation (Ramsay \& Oxley 1996).

In this context, the knowledge of palaeoecological conditions is very important, as the composition of past natural vegetation as well as pre-Columbian anthropogenic landscapes and climate conditions are often not well known. Despite the importance of this knowledge, only a limited number of palaeoecological studies are available from the Ecuadorian Andes, mainly because of the steep slopes and scarcity of natural archives in this region (Bush et al. 2007). In the Andean Depression region, which includes our study area, studies on vegetation history and upper forest line changes are increasing. Pollen records from the southern Ecuadorian Andes are provided by the German-Ecuadorian Research Unit (www.tropicalmountainforest.org), focusing on the Podocarpus National Park (PNP) area and its surroundings. These studies demonstrate marked past vegetation changes, as well as climate changes. The glacial period in general is marked by cold and wet conditions. A warm and dry early to mid-Holocene is shown, while wetter conditions are recorded in the late Holocene. The available studies also demonstrate changing environments, e.g. 
by differing fire intensity and human impact regimes, and their influence on local and regional ecosystem dynamics during the late Quaternary (Niemann \& Behling 2008, 2010; Brunschön \& Behling 2009, 2010; Niemann et al. 2009, 2013; Brunschön et al. 2010, Jantz \& Behling 2012, Rodríguez \& Behling 2011, Villota et al. 2012).

The upper forest line (UFL) is the maximum elevation where continuous forest occurs (Bakker et al. 2008). In the Andean Depression region, the UFL is highly variable and still poorly defined compared with other UFLs in the Andes. In the Andean Depression, the UFL is comparatively low between 2800 and 3300 m a.s.l. (Richter \& Moreira-Muñoz 2005, Beck et al. 2008b), while (e.g.) north of the Andean Depression the UFL is located at $\sim 3600 \mathrm{~m}$ (Richter et al. 2008, Moscol Olivera \& Hooghiemstra 2010). In the Andean Depression the UFL is characterized by high species richness, consisting of about 20 tree species (e.g. Weinmannia, Clusia).

Of particular interest is the genus Polylepis, often forming the UFL in the northern and central Andes (Wille et al. 2002, Hansen et al. 2003, Bakker et al. 2008), but interestingly missing in the Andean Depression (Beck et al. 2008c, Peters 2009). Polylepis is represented by eight species distributed throughout the Ecuadorian Andes (Simpson 1979, Schmidt-Lebuhn et al. 2006). Apparently, Polylepis forest would naturally occur primarily on the slopes and more protected ridges of the area, and might have had a greater range in the past (Simpson 1986, Romoleroux 1992, Kessler 1995, Purcell \& Brelsford 2004). Moisture and temperature have been identified as controlling factors on Polylepis distribution in the Andes (Rada et al. 1996). Moisture from clouds permits Polylepis to survive in areas of otherwise low moisture availability (Gosling et al. 2009a). However, frequent strong winds and the extremely high precipitation are thought to be the main factors for the absence of Polylepis on the eastern Andean slope in Ecuador, because the genus tends to avoid perhumid regions (Kessler 1995, Richter \& Moreira-Muñoz 2005). The Polylepis forests represent one of the world's most threatened ecosystems (Kessler 2006). Indeed, the current patchy distribution pattern of Polylepis woodland has been widely attributed to human activity with the onset of fire (Kessler 2002, Renison et al. 2002, Cierjacks et al. 2008, Urrego et al. 2011). Due to its patchy distribution and location at the highest elevations of the forest limit, this genus has become the focus of several ecological studies (Enrico et al. 2004, Cierjacks et al. 2007, Kessler et al. 2007, Seltmann et al. 2007).

In this paper, we present the palaeoecological results from the mountain rainforest of the El Cristal region located in the eastern part of the Cordillera Real of southern Ecuador. Unfortunately, 
nowadays the eastern slopes of the Ecuadorian Andes are under increasing anthropogenic pressure. Consequently, the vegetation displays patterns directly attributable to human intervention as well as traces of former natural habitats. This enhances our knowledge of how past processes, e.g. past vegetation, human impact as well as climate change, have influenced ecosystem dynamics and the development of the outstanding diversity in the study region. The point of special interest is how did anthropogenic or climatic conditions influence the occurrence and absence of Polylepis in the study area?

\subsection{The Study region}

\subsubsection{Location}

The study area El Cristal is located on the eastern slope of the Cordillera Real between the Saraguro villages of El Tibio and El Cristal in the Protective Forest Corazón de Oro (Zamora Chinchipe Province) (Fig. 1). It is situated in the Girón-Cuenca (southern Ecuador) and Huancabamba (northern Peru) Andean Depression. Here, mountains barely reach heights of 4000 $\mathrm{m}$ and no active volcanoes are present.

The Protective Forest Corazón de Oro covers 54000 ha and is located in the north of the Podocarpus National Park (PNP) between Loja and Zamora Chinchipe Provinces. At the time of its declaration in 2000, the Protective Forest Corazón de Oro encompassed more than 15 settlements, $30 \%$ of the area was already converted into pasture and another $30 \%$ of the forest cover was interspersed with pastures (UNL et al. 2006).

The sediment core analyzed was derived from the small swamp, $20 \mathrm{~m}$ in diameter, found in a shallow closed basin, which in this study is called "El Cristal" (EC). The core was taken at $2056 \mathrm{~m}$ a.s.I. ( $\left.3^{\circ} 51^{\prime} 38.5^{\prime \prime} \mathrm{S}, 79^{\circ} 03^{\prime} 40.1^{\prime \prime} \mathrm{W}\right)$. The area around the study site is very disturbed. During fieldwork, much human activity was observed, mainly slash and burn fields, clear cuttings, fire, and paths. The path close to the swamp is used as the main connection between two villages. 


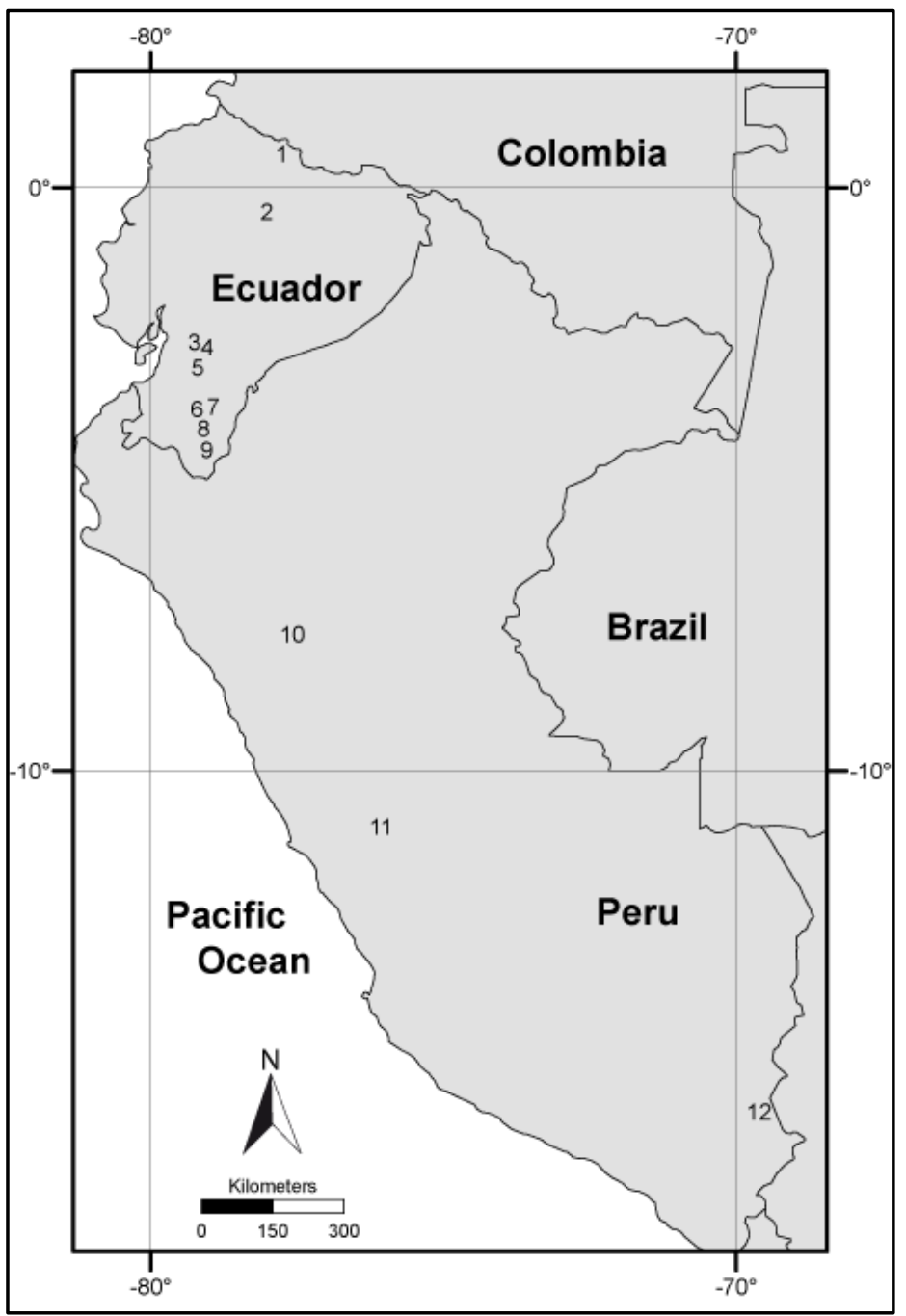

Figure 1. Map of the Andes of Ecuador, Peru and Bolivia in South America, showing the location of the different studiy sites from the Ecuadorian Andes and neighboring countries. 1. Guandera Biological Reserve; 2. Laguna Yaguarcocha; 3. Lagunas Chorreras; 4. Lake Surucucho; 5. Tres Lagunas; 6. El Tiro; 7. Cocha Caranga; 8. Cerro Toledo; 9. El Cristal; 10. Laguna Junín; 11. Laguna de Chochos; 12. Lake Titicaca.

\subsubsection{Geology}

The eastern Andean Cordillera is mainly built up of Paleozoic metamorphic rocks (Baldock 1982) of widely varying metamorphic grade. The local bedrock is dominated by white limestones, yellow sandstones, quartzites and black phyllites with some granitic intrusions (Litherland et al. 1994, Hungerbühler et al. 2002). The basin margins contain conglomerates of metamorphic debris and argillaceous sandstone in the Miocene layers (Sauer 1971). 


\subsubsection{Climate}

The climate of the Ecuadorian Andes is dominated by the tropical trade wind regime, which is well established in the mid- and higher troposphere, with strong easterly winds throughout the year (Emck 2007, Bendix et al. 2008). The southeastern part of the country, encompassing the El Cristal area, is mainly influenced by easterly winds. Precipitation and humidity continuously rise on the eastern side to the crest regions, where rainfall can reach up to $2176 \mathrm{~mm} \mathrm{yr}^{-1}$ (Bendix et al. 2008). The main rainy season lasts from April to August, but rainfall is high throughout the year. Temperature varies according to the time of day and season. The mean annual minimum temperature is $\sim 5^{\circ} \mathrm{C}$ and the maximum is $\sim 29.1^{\circ} \mathrm{C}$, recorded in the weather station located $12 \mathrm{~km}$ from the study area at the Research Station San Francisco at $1960 \mathrm{~m}$ a.s.I. (Bendix et al. 2008).

\subsubsection{Vegetation}

The vegetation of the study area is mainly dominated by the lower mountain forest and upper mountain rainforest. The lower mountain forest (ca. 1500-2000 m a.s.l.) is characterized by Alchornea glandulosa, Piptocoma discolor, Acalypha sp., Hyeronima macrocarpa, Vismia tomentosa, Miconia imitans, Cedrela montana, Ficus sp., Piper sp. and Celtis iguanaea (Homeier et al. 2008). The upper mountain rainforest, between $c a$. $2000-2700 \mathrm{~m}$, is characterized by Hedyosmum sp, Weinmannia pinnata, Purdiaea nutans, Clethra revoluta, Clusia elliptica, Graffenrieda emarginata, Tibouchina lepidota, Heliocarpus americanus, Myrica pubescens, Myrsine andina, Podocarpus oleifolius and Prumnopitys montana, and Schefflera pentandra (Homeier et al. 2008). However, due to human activity, the study site is also surrounded by taxa of páramo vegetation (mainly herbs), which is composed of Puya eryngioides, Hypericum decandrum, Rhynchospora vulcani, Gaultheria amoena, Pernettya prostrata, Vaccinium floribundum Calamagrostis macrophylla, Neurolepis elata, Chusquea neurophylla, and Valeriana plantaginea (Homeier et al. 2008). There are also some types of subpáramo taxa, with vascular species such as Gynoxis cuicochensis, Baccharis genistelloides, Chuquiraga jussieui, Diplostephium empetrifolium, Gaultheria reticulata, Hesperomeles ferruginea, Symplocos sulcinervia (Homeier et al. 2008).

El Cristal is an area where tropical mountain rainforest has been highly modified by human activity. Forest remnants and secondary vegetation, pastures, small fields and other open areas dominate the landscape. However the borders of the settlements are covered with non-colonized disturbed primary forest on very steep, almost unreachable slopes (Gerique 2010). 


\subsubsection{Human settlement}

Human-environment relationships have a long and diverse history in the region of the northern Andes. The earliest record of human occupation in the region of the southern Ecuadorian Andes close to El Cristal is Cubilán (10 000 cal yr BP), where scant traces of hunter-gatherers, nomads or semi-nomads have been found (Temme 1982). The first human activity in the region of Loja and Zamora is dated at around $4000 \mathrm{cal}$ yr BP, but human activities may have occurred in the dry interAndean valley much earlier (Guffroy 2004).

The present-day Mestizo and Saraguro settlers came from neighboring regions over the last 80 years and colonized the area of the Protective Forest Corazón de Oro. The El Cristal village was founded in the 1970s during the timber boom (Gerique 2010). Both Saraguros and Mestizos make little use of forest resources. The forest supplies them with timber for their own use (houses, buildings) or for sale, with a few species used mainly for food, medicine, or fuel. However, forest areas are in the main considered a reserve for new pastures and as plots for maize production; what is important in productive terms is the potential for agricultural use of the underlying soil (Wunder 1996).

\subsection{Material and Methods}

\subsubsection{Sediment extraction}

The "El Cristal" (EC) sediment core was recovered using a Russian corer. The total length of the recovered core was $170 \mathrm{~cm}$. Sections of $50 \mathrm{~cm}$ were placed in PVC tubes which had been split in half longways and covered with plastic film and stored under dark and cold $\left(+4{ }^{\circ} \mathrm{C}\right)$ conditions at Georg-August University before processing.

Accelerator mass spectrometer (AMS) radiocarbon dating of 6 subsamples containing organic material was undertaken at the Radiocarbon Laboratory at the University of Erlangen-Nürnberg

(Germany). The ${ }^{14} \mathrm{C}$ dates were calibrated using the curve CalPal 2007 HULU for the northern hemisphere of the CalPal software (Weninger et al. 2004).

\subsubsection{Palynological analysis}

The EC core was sampled at $4 \mathrm{~cm}$ intervals along the core, resulting in 41 subsamples of $0.5 \mathrm{~cm}^{3}$. All samples were processed using the standard pollen analytical methods (Fægri \& Iversen 1989). 
One tablet of exotic Lycopodium clavatum spores, containing $18583 \pm 762$ spores, was added to each sample before treatment as a marker for calculation of pollen and charcoal concentrations as well as influx. A minimum of 300 pollen grains was counted for each sample. The pollen sum includes pollen of herbs, shrubs trees and indeterminate taxa, but excludes fern spores and pollen of aquatic taxa. The spores of Pteridophyta, Isoëtes and Bryophyta were counted and quantified as percentages based on the pollen sum. The identification of pollen and spores is based on the reference published by Hooghiemstra (1984), as well as electronic pollen keys of Ecuador, kept at the Department of Palynology and Climate Dynamics, University of Göttingen, and the South American Pollen Database (Bush \&Weng 2007). Reference collections of recent material, held at the Department of Palynology and Climate Dynamics, were also used. They contain about 3000 Neotropical taxa (Behling 1993) and ca. 620 Ecuadorian taxa, respectively. Identified taxa were classified into ecological groups that correspond to the prevailing vegetation types: Lower Mountain Rainforest (LMF), Upper Mountain Rainforest (UMF), Subpáramo, Páramo and Pteridophyta. In particular, for the Holocene period of the core Páramo also includes taxa that correspond to anthropogenic grasslands. The pollen types that could not be identified were grouped in the indeterminate taxa. A full list of identified pollen and spore taxa from the El Cristal core can be found in Table 1. For charcoal analysis, the technique used was developed by Finsinger et al. (2008), which estimated that charcoal particles correspond to the concentration of Lycopodium clavatum spores (marker). Charcoal particles were counted up to a total count of 100 Lycopodium clavatum spores. The counted charcoal particles were separated into two groups of different particle sizes $(10-50 \mu \mathrm{m}$ and $50->100 \mu \mathrm{m})$ to give more detailed information about the fire history (Sadori \& Giardini 2007). Fragments between 10 and $50 \mu \mathrm{m}$ indicate regional fires, and fragments between 50 and $>100 \mu \mathrm{m}$ local fires (Whitlock \& Larsen 2001). 
Table 1. List of identified pollen and spore taxa from the El Cristal (EC) core.

\begin{tabular}{|c|c|c|c|c|c|}
\hline LMF & UMF & Subpáramo & Páramo & Other & Pteridophyta \\
\hline Acalypha & Alnus acuminata & Ambrosia type & Apiaceae & Alternanthera type 1 & Isoëtes \\
\hline Alchornea & Clethra & Asteraceae subf. Cichorioideae & Arcytophyllum & Amaranthaceae/Chenopodiaceae & Blechnum type \\
\hline Celtis & Clusia type & Baccharis type & Brassicaceae & Euphorbiaceae & Cyatheaceae \\
\hline Hyeronima & Dodonea & Ericaceae & Caryophyllaceae & cf Euphorbiaceae & Huperzia \\
\hline Mimosaceae & Escallonia & cf Ericaceae psilate & Centropogon & Palicourea & Jamesonia \\
\hline Moraceae/Urticaceae & Hedyosmum & Gunnera & Cyperaceae & & Osmunda \\
\hline Oreopanax & Ilex type & Hypericum & Eryngium type & & \\
\hline Piper & Melastomataceae & Lorantaceae & Fabaceae type 1 & & \\
\hline Proteaceae & Myrica & Monnina & cf Fabaceae & & \\
\hline Trema type & Myrsine & Muehlenbeckia/Rumex type & Gentianaceae & & \\
\hline \multirow[t]{10}{*}{ Verbena } & Podocarpaceae & Oxalis & Geraniaceae & & \\
\hline & Polylepis-Acaena type & & Iridaceae & & \\
\hline & Purdiaea nutans & & Macrocarpaea & & \\
\hline & Solanum type & & Plantago rigida type & & \\
\hline & Symplocos (type 3p) & & Poaceae & & \\
\hline & Symplocos (type 2p) & & Puya & & \\
\hline & Vallea & & Ranunculus & & \\
\hline & Weinmannia & & Senecio type & & \\
\hline & & & Valeriana & & \\
\hline & & & Xyris & & \\
\hline
\end{tabular}




\subsubsection{Data analysis}

The software TILIA was used for data calculation of percentages and sums, as well as pollen and charcoal concentration and influx. TILIAGRAPH software was used to illustrate the data, as well as stratigraphy and the calibrated and uncalibrated dates (Grimm 1987). The program CONISS was used to conduct a cluster analysis of the pollen data, which includes taxa of the pollen sum, to generate a dendrogram (Grimm 1987), which helped to identify the pollen zones.

\subsection{Results}

\subsubsection{Stratigraphy}

The sediment core EC mainly consists of silt, clay, and organic material. Between 170 and $120 \mathrm{~cm}$ core depth, the sediment has little organic material; silty and clayey material is dominant with a dark/light grayish color. From $120 \mathrm{~cm}$ to the top of the core the sediments are more compact and with decomposed material. Between 120 and $80 \mathrm{~cm}$, the organic material is highly decomposed and has a dark/light brown color. Between 80 and $26 \mathrm{~cm}$ less decomposed organic material is found with the presence of a few fine roots. Between 26 and $0 \mathrm{~cm}$ the organic material is little decomposed with many plant remains. A detailed description of the stratigraphic units is given in Table 2.

Table 2. Stratigraphic description of the sediment core El Cristal (EC).

\begin{tabular}{|c|c|}
\hline Depth (cm) & Description \\
\hline $0-26 \mathrm{~cm}$ & $\begin{array}{l}\text { Very little decomposed organic material; with plant remains (roots); light } \\
\text { brown color }\end{array}$ \\
\hline $26-80 \mathrm{~cm}$ & Little decomposed organic material with roots, dark brown color \\
\hline $80-90 \mathrm{~cm}$ & Decomposed organic material, dark brown color \\
\hline $90-100 \mathrm{~cm}$ & Highly decomposed organic material, dark brown color \\
\hline $100-122 \mathrm{~cm}$ & $\begin{array}{l}\text { Highly decomposed organic material; brownish colored; some darker belt } \\
\text { between } 120-125 \mathrm{~cm}\end{array}$ \\
\hline $122-130 \mathrm{~cm}$ & Clayey material with little organic material, dark-grayish color \\
\hline $130-134 \mathrm{~cm}$ & Silt material compact, light-grayish color \\
\hline $134-140 \mathrm{~cm}$ & Clayey material compact, dark-grayish color \\
\hline $140-170 \mathrm{~cm}$ & Silt material compact, light-grayish color \\
\hline
\end{tabular}




\subsubsection{Chronology and pollen zonation}

The chronology of the core EC is based on six radiocarbon dates (Table 3). Extrapolation of the dates suggests that the base of the core has an age of $19750 \mathrm{cal}$ yr BP that probably reflects the beginning of sediment accumulation. The six radiocarbon dates suggest that the sediments have accumulated since the late Pleistocene.

The age-depth model (Fig. 2) reveals that the average sediment accumulation rate of the complete core is $0.32 \mathrm{~mm} \mathrm{yr}^{-1}$. The different intervals rates are: $0.05 \mathrm{~mm} \mathrm{yr}^{-1}$ (19 750 to $14500 \mathrm{cal} \mathrm{yr} \mathrm{BP}$ ), $0.10 \mathrm{~mm} \mathrm{yr}^{-1}$ (14 500 to $3500 \mathrm{cal}$ yr BP), $0.24 \mathrm{~mm} \mathrm{yr}^{-1}$ (3500 to $1300 \mathrm{cal} \mathrm{yr} \mathrm{BP),} 0.34 \mathrm{~mm} \mathrm{yr}^{-1}$ (1300 to $380 \mathrm{cal} \mathrm{yr} \mathrm{BP}$ ) and $0.93 \mathrm{~mm} \mathrm{yr}^{-1}$ ( 380 to -57 cal yr BP).

The CONISS cluster analysis and major changes in the pollen assemblages suggest five main pollen zones (EC-I to EC-V) with subzones (EC-Ila, EC-IIb; EC-IIIa, EC-IIIb, and EC-IVa, EC-IVb).

Table 3. List of AMS radiocarbon ${ }^{14} \mathrm{C}$ dates and calibrated ages from the El Cristal (EC) core using the curve CalPal 2007 HULU of the CalPal software.

\begin{tabular}{lllcc}
\hline Lab. Code & Depth $(\mathbf{c m})$ & Dated Material & ${ }^{14}$ C age $(\mathbf{y r ~ B P})$ & $1-\sigma(\mathrm{cal}$ yr BP) \\
\hline Erl-16584 & $45-46$ & Organic material & $346 \pm 50$ & $404 \pm 65$ \\
Erl-16084 & $95-96$ & Organic material, with recent roots & $1927 \pm 41$ & $1780 \pm 224$ \\
Erl-16083 & $132-133$ & Charcoal & $3527 \pm 45$ & $3743 \pm 128$ \\
Erl-16977 & $141-142$ & Organic material, with recent roots & $4335 \pm 50$ & $4923 \pm 55$ \\
Erl-16976 & $153-154$ & Organic material & $11318 \pm 84$ & $13221 \pm 123$ \\
Erl-16585 & $166-168$ & Organic material & $14928 \pm 123$ & $18214 \pm 254$ \\
\hline
\end{tabular}




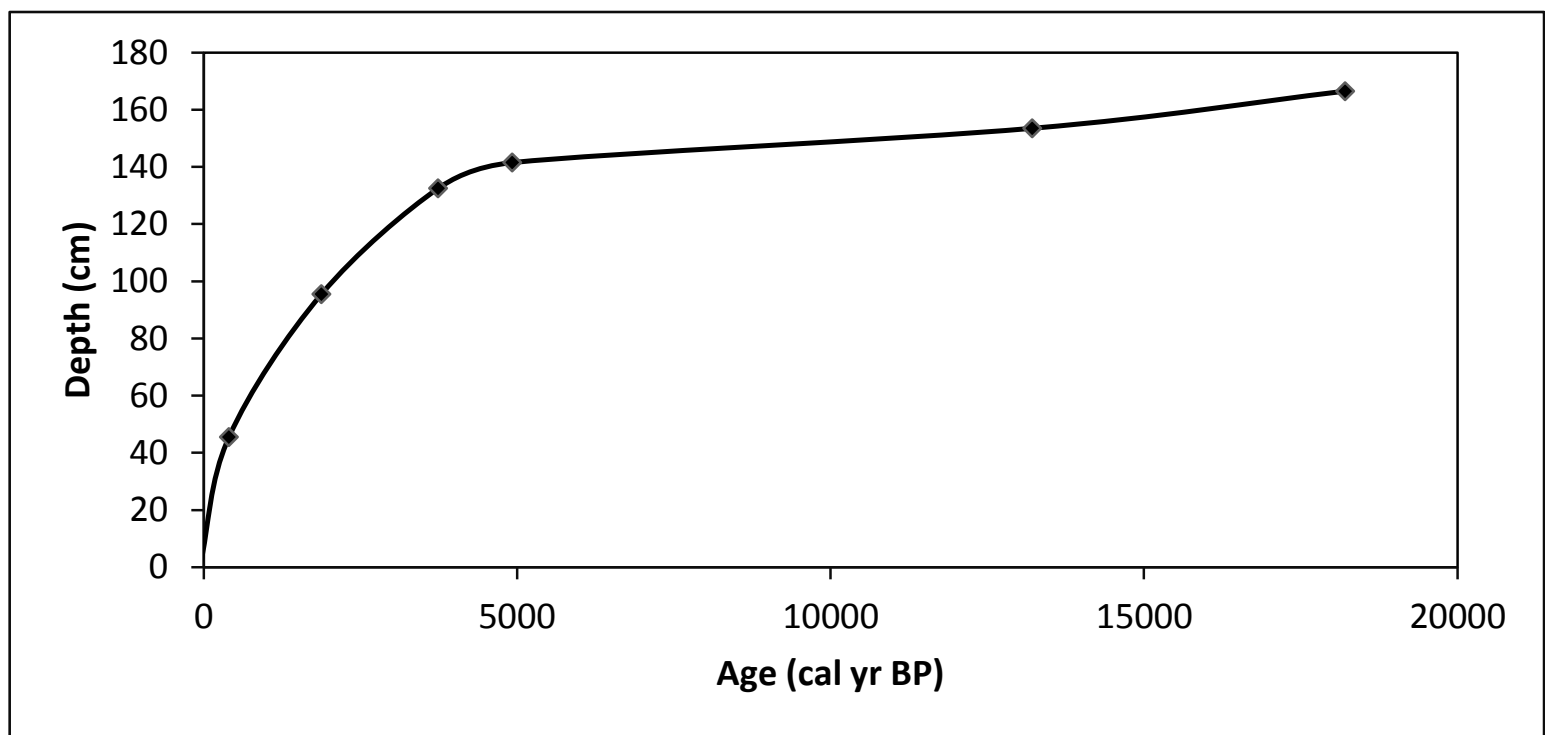

Figure 2. Age-depth model (core depth in $\mathrm{cm} / \mathrm{cal}$ yr BP) for the El Cristal (EC) core based on 6 radiocarbon dates.

\subsubsection{Description of the pollen diagram}

A detailed pollen percentage diagram displays 22 different pollen taxa with a representation of $>2 \%$ out of 70 pollen types, and 5 spores types with a representation of $>2 \%$ out of 11 identified taxa (Fig. 3). The summary percentage diagram (Fig. 4) shows the pollen and spores grouped into vegetation types: Lower Mountain Rainforest (LMF), Upper Mountain Rainforest (UMF), Subpáramo, Páramo, and Pteridophyta, and concentration and influx of pollen and charcoal.

Pollen concentration and influx vary between 100000 and 800000 grains $/ \mathrm{cm}^{3}$ and between 3000 and 15000 grains $/ \mathrm{cm}^{2} / \mathrm{yr}$, respectively, with a very high pollen concentration and influx in subzone EC-Illa with 1400000 grains $/ \mathrm{cm}^{3}$ and 28000 grains $/ \mathrm{cm}^{2} / \mathrm{yr}$, respectively.

The charcoal concentration of the two counted fractions varies between 6000 000-20000 000 particle $/ \mathrm{cm}^{3}$ (small fraction) and 100 000-600 000 particles $/ \mathrm{cm}^{3}$ (large fraction), with a high concentration for the small fraction at zones EC-V and EC-III with 30000000 particles $/ \mathrm{cm}^{3}$, and for the large fraction at zone EC-III with 900000 particles $/ \mathrm{cm}^{3}$. The charcoal influx for both counted fractions varies in the sediment core between 100 000-500 000 particles $/ \mathrm{cm}^{2} / \mathrm{yr}$ (small fractions) and 30 000-10 000 particles $/ \mathrm{cm}^{2} / \mathrm{yr}$ (large fraction). Charcoal influx for small and large fractions at zone EC-V shows a high value with 2000000 and 60000 particles $/ \mathrm{cm}^{2} / \mathrm{yr}$, respectively. 
Zone EC-I (170-152 cm; 7 samples, ca. 19 750-12 530 cal yr BP) is characterized by a low pollen representation of LMF taxa (5-8\%) mainly due to low values of Alchornea, Acalypha and Clusia (0$1 \%)$. This zone is marked by relatively high values of UMF taxa (45-55\%), with an increase during this zone especially in Hedyosmum and Myrica (from 10 to 15\%), Alnus (2-4\%) and PolylepisAcaena type (5\%). Subpáramo taxa show the lowest values of the record (6-8\%), mainly by Asteraceae and the Muehlenbeckia/Rumex type (1-3\%). Páramo pollen taxa show stable values (30\%) such as Poaceae (10-15\%). In this zone Pteridophyta spores (10-14\%) are mainly represented by Cyatheaceae (5-8\%) and Jamesonia (4\%). Isöetes spores (up to 50\%), which are not included in the sum of Pteridophyta, are very frequent in this zone.

Subzone EC-Ila (152-140 cm; 3 samples, ca. 12 530-7800 cal yr BP). LMF shows a stable representation (9\%) by Moraceae/Urticaceae (3-5\%), Alchornea (2\%) and Acalypha and Clusia (01\%). As well as LMF, UMF pollen taxa show stable representation (55-60\%) with Hedyosmum (15\%), Myrica (12\%), Polylepis-Acaena type (5-8\%) and Melastomataceae (2-5\%). Subpáramo taxa increase slightly (16\%) mainly by Ericaceae pollen (5-10\%) and the Muehlenbeckia/Rumex type present the highest values (5-7\%) of the record in this subzone. Páramo taxa vary between 18 and $28 \%$, especially due to values of Poaceae pollen from 10 to $15 \%$ and Plantago sp. (5-7\%). Pteridophyta spores show stable values (10-16\%), mainly by Cyatheaceae 10\% and Jamesonia (3$5 \%)$. Isöetes values decrease slightly (20\%).

Subzone EC-IIb (140-128 cm; 3 samples, ca. 7800-3600 cal yr BP) is characterized by a slightly higher representation of LMF pollen (15\%), e.g. Alchornea (3-5\%) compared with the previous subzone. UMF taxa decreased from 60 to $45 \%$, especially due to lower representation of Hedyosmum (2-4\%) and the absence of Alnus. At the lower part of this zone the Polylepis-Acanena type present the highest percentages (8\%) of the record as well as Myrsine (5-10\%). Subpáramo pollen taxa show a stable proportion (15\%) such as Ericaceae (6\%) and Asteraceae (4-6\%). Páramo pollen taxa increase slightly from 28 to $35 \%$, mainly by Plantago sp. (10\%) and Cyperaceae (4-7\%). At the top of this subzone Pteridophyta show stable values (15\%), primarily by Cyatheaceae $13 \%$ and Osmunda spores (14\%). In this subzone spores of Isöetes are absent.

Subzone EC-IIla (128-94 cm; 9 samples, ca. 3600-1850 cal yr BP) is marked by a stable representation of LMF taxa (13\%), especially by pollen of Moraceae/Urticaceae (5-12\%) and Alchornea (4-6\%). UMF taxa reach highest values between 60 and $70 \%$ of the record, mainly due to pollen of the Escallonia type, Purdiaea nutans and Clethra (5-15\%); also Weinmannia and 
Melastomataceae pollen taxa with (8-12\%). Subpáramo taxa such as the Muehlenbeckia/Rumex type and Ericaceae (2-5\%) show stable values and Asteraceae with (6-12\%). Compared to the previous subzone, páramo pollen decreased from $20 \%$ to $15 \%$. This is mainly due to decreasing values of Poaceae (5-10\%) and Cyperaceae (2-3\%). The Plantago sp. show increased values (8\%) at the lower part of the subzone. In this subzone the Pteridophyta group shows the lowest value of the record (5\%), mainly due to the absence of Huperzia, Cyatheaceae and Jamesonia.

Subzone EC-IIlb (94-78 cm; 4 samples, ca. 1850-1380 cal yr BP) is characterized by a stable representation of LMF taxa, mainly due to Moraceae/Urticaceae (5-15\%); also Alchornea, Acalypha and Clusia with (1\%). UMF pollen shows lowest amounts within this subzone, especially Hedyosmum (2-4\%), the Escallonia type, Purdiaea nutans and Clethra (1-3\%) are represented at low levels; however Weinmmania (4-7\%) and Melastomataceae (6-10\%) show stable amounts. Subpáramo taxa show highest values in this subzone (20-30\%), mainly due to Asteraceae pollen (15-30\%). Compared to decreasing values of the previous subzone, páramo taxa show slightly higher proportions (35-40\%), mainly due to higher values of Poaceae $(30 \%)$ and Cyperaceae (5$10 \%)$. Compared with the previous subzone, Pteridophyta increased strongly, mainly due to Osmunda spores, which increased to higher values between $15 \%$ and $20 \%$; also Huperzia (5\%).

Subzone EC-IVa (78-62 cm; 4 samples, ca. 1380-900 cal yr BP) shows a stable proportion of LMF pollen (10\%). UMF taxa increase slightly and vary from 55 to $60 \%$, mainly by pollen of Escallonia type, Purdiaea nutans and Clethra (5-10\%), and also Melastomataceae (10-18\%). Subpáramo shows lower values of Asteraceae (2-5\%). Compared with the previous subzone, páramo taxa show stable percentages, especially by Poaceae (15-25\%). Strong decrease in Pteridophyta (2\%) is found.

Subzone EC-IVb (62-46 cm; 4 samples, ca. 900-500 cal yr BP) is characterized by stable proportions of LMF pollen taxa, mainly Moraceae/Urticaceae (9\%). Compared with the precious subzone, proportion of UMF taxa decreased, mainly due to Escallonia type, Purdiaea nutans and Clethra (2-4\%). The values of Myrsine (4-7\%) within this subzone are higher. Melastomataceae (13\%) show stable values. Percentages of subpáramo taxa remain stable, such as Muehlenbeckia/Rumex type (5\%). Páramo taxa show stable values and are dominated by pollen of Poaceae (12-20\%). 
Zone EC-V (46-0 cm; 7 samples, ca. 500 to -60 cal yr BP) is characterized by high representation of LMF pollen (15 to $20 \%$ ) compared with the previous zone. Mainly Moraceae/Urticaceae pollen increased to $12 \%$, as well as Clusia and Acalypha (1-3\%). UMF taxa remain stable between 30 and $40 \%$, with Weinmannia (2-5\%) and Myrsine (3-6\%), while Hedyosmum increases from 3 to $6 \%$ at the top of the zone. Pollen of Melastomataceae (6-11\%) shows decreasing values. Compared with the previous zone, pollen of subpáramo decreases from 17 to $10 \%$. This is mainly due to decreasing values of Muehlenbeckia/Rumex type and Ericaceae (1\%). Páramo taxa increase in this zone, especially Poaceae pollen from 20 to $25 \%$ at the lower part of this zone. Pteridophyta spores $(1-2 \%)$ show the lowest values of the complete record. 


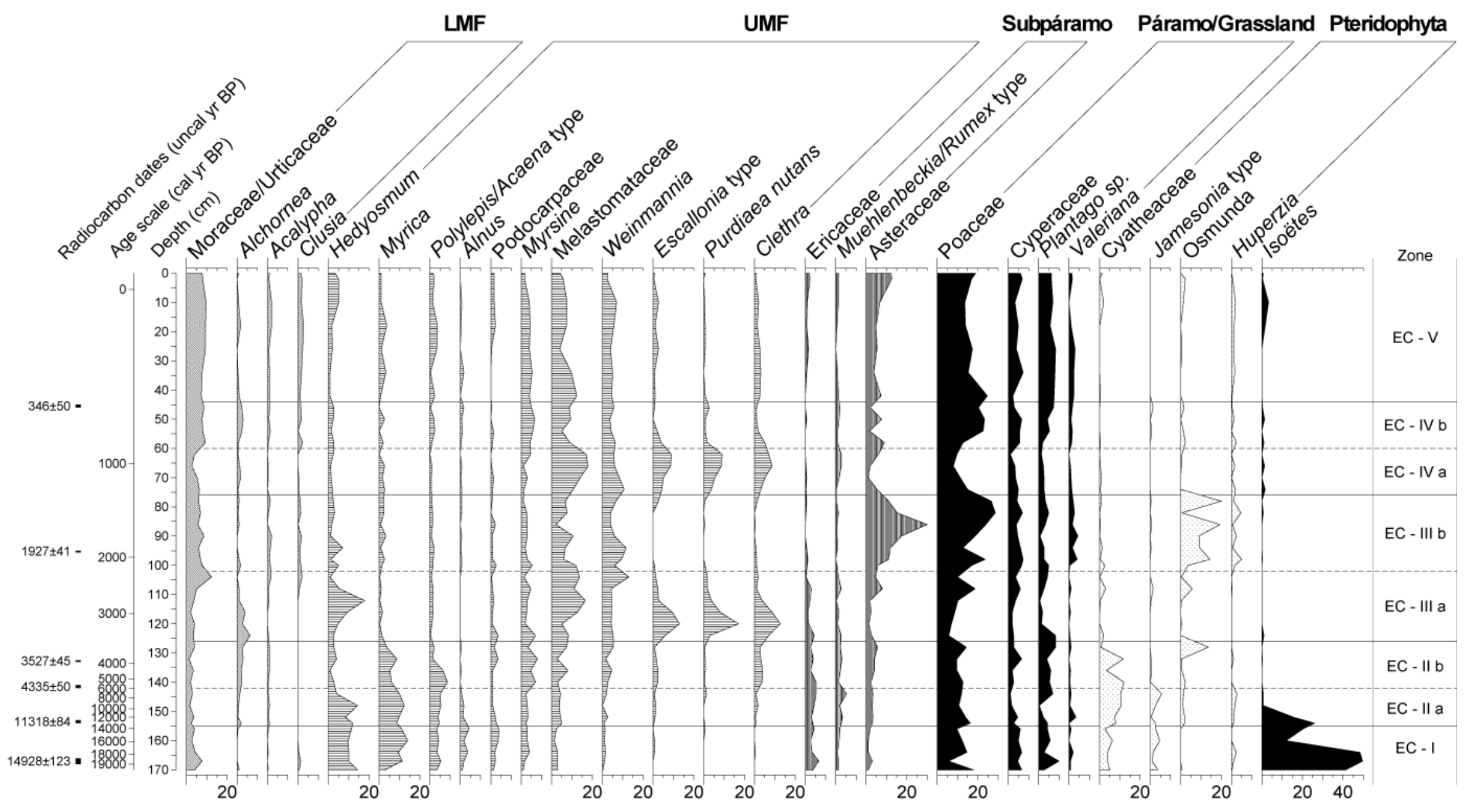

Figure 3. Pollen percentage diagram of the El Cristal (EC) core showing selected fossil pollen and spore taxa grouped into Lower Mountain Rainforest (LMF), Upper Mountain Rainforest (UMF), Subpáramo, Páramo/grassland, and Pteridophyta. 


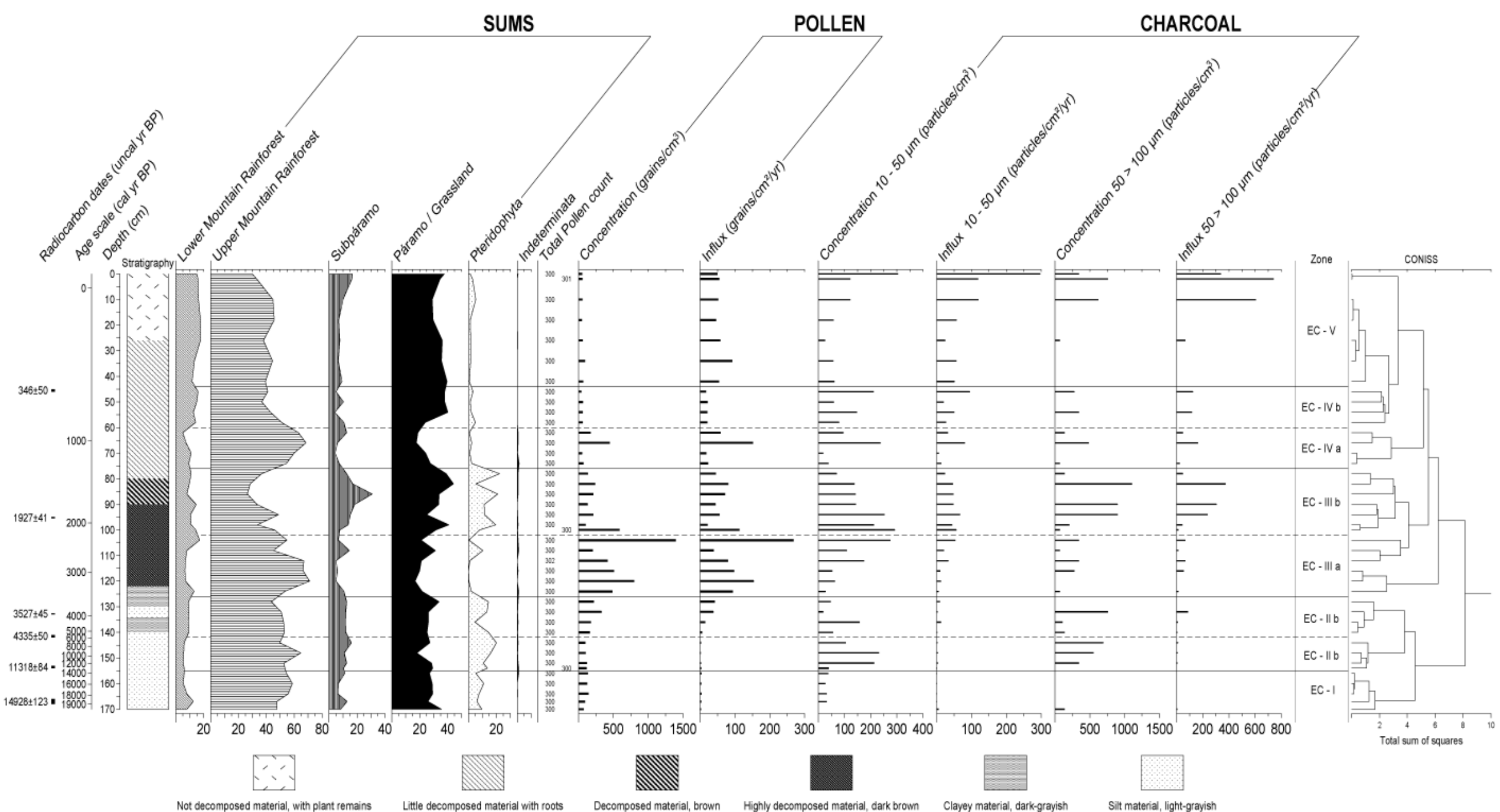

Figure 4. Summary pollen percentage diagram of the El Cristal (EC) core showing radiocarbon dates (uncal yr BP), age scale (cal yr BP), vegetation groups, pollen sum, pollen concentration and influx, charcoal concentration and influx, and the CONISS dendrogram. 


\subsection{Interpretation and discussion of the pollen data}

Mountain regions provide excellent conditions for the study of past climatic changes because of the close relationship between climate and environment (Gosling and Bunting 2008). Especially the "El Cristal" (EC) core, at 2056 m elevation, reflects the local development and vegetation dynamics of the eastern slope of the Cordillera Real (Protective Forest Corazón de Oro) over the last 19750 cal yr BP.

\subsubsection{Late Pleistocene}

The late Pleistocene period, from about 19750 to 12500 cal yr BP (zone EC-I), shows a significant presence of mountain rainforest taxa (ca. $60 \%$ of all pollen) in the study area, especially of taxa of the Upper Mountain Rainforest (UMF) and a smaller proportion of Lower Mountain Rainforest (LMF) taxa. Subpáramo (ca. 10\% of pollen) and páramo vegetation ( $30 \%$ of pollen) are present during this period. A high proportion of UMF, as well as a relatively high proportion of páramo taxa suggest that an open mountain rainforest occupied the region during this period. The high proportion of silt within the sediment deposits during this period could indicate that the soils were unstable and vegetation cover incomplete, resulting in higher rates of erosion.

The LMF was represented mainly by Moraceae/Urticaceae probably located at lower elevations. Despite that, Moraceae/Urticaceae pollen can be wind-transported over longer distances, especially in the study area where the easterly winds are dominant (Hansen \& Rodbell 1995, Bush \& Rivera 2001, Weng et al. 2004, Gosling et al. 2009b, Moscol Olivera et al. 2009). Studies by Niemann et al. (2010) based on pollen rain transects reveal that the altitudinal distribution of the present vegetation types and certain taxa are well reflected in the modern pollen rain data. Also a pollen trapping study by Jantz et al. (2013) reveals that the distinct pollen spectrum of modern pollen rain reflects local to regional vegetation conditions. Main components of the UMF during the late Pleistocene were Hedyosmum, Myrica, Polylepis, Alnus and Podocarpaceae. The occurrence of Hedyosmum, which is abundant during this period, indicates relatively wet conditions. Also, the presence of Myrica, which occurs in sloping humid ground and eroded Andes slopes, and Alnus, which occurs in marshy and disturbed areas (Marchant et al. 2002), indicates humid conditions and eroded soils. 
Evidence of small populations of Polylepis at low elevation in the northern part of the Andean Depression is interesting, since it does not occur today (Fig. 3). Recently, populations of Polylepis have also been reported in the southern part of the Andean Depression in southernmost Ecuador next to the border of Peru (Rodríguez \& Behling 2012, Villota et al 2012). However, Polylepis population were absent in the records of the central part of the Andean Depression where the Podocarpus National Park (PNP) is located (Brunschön \& Behling 2009, Niemann \& Behling 2008), probably due to high precipitation and strong winds. Similar proportions of Polylepis to those in EI Cristal have been described in the record from Lake Surucucho during the late glacial outside of the Andean Depression at $\mathbf{3 1 8 0} \mathrm{m}$ on the eastern face of the Cordillera Occidental (Colinvaux et al. 1997). A comparable distribution of Polylepis population has been reported from the high Andes of Peru, Laguna Junin record, at $4100 \mathrm{~m}$ in the central Peruvian Andes, which suggests that between 16000 and 12000 yr BP a forest line dominated by Polylepis and Asteraceae covered the plain (Hansen et al. 1984). The results from the northern as well as from the southern part of the Andean Depression indicate the movement of Polylepis populations into the Andean Depression during glacial times, which have apparently not reached the central part.

Subpáramo taxa were dominated mainly by Ericaceae and páramo mainly by Poaceae in the study area. Studies suggest that the relatively high pollen proportion of Poaceae in the UMF vegetation zone possibly relates either to wind transport from higher elevations of the surrounding higher mountains or to the occurrence of forest grasses with high pollen production in the study area (Hansen et al. 1984, Bush et al. 1990, Niemann et al. 2010). The high abundance of páramo taxa and the presence of Polylepis provide a robust overall image of cold conditions during this period.

During this time Isoëtes was abundant in the basin at the study site. Isoëtes is a good proxy for the existence of a shallow lake, or extensive shallow margins, and it is sensitive to hard freezes (Cleef 1978, Ybert 1988, Bosman et al. 1994).

In addition, in the El Cristal record there is no marked shift of the upper forest line (UFL). The study site is located at lower altitudes and forest taxa dominate the area with relatively stable values during the late Pleistocene and Holocene (Fig. 4). As already mentioned, the UFL in the southern part of Ecuador ranges from 2800 to $3300 \mathrm{~m}$ a.s.l. and the study area is located at $2056 \mathrm{~m}$ elevation. However, the presence of páramo taxa at lower elevations during the late Pleistocene shows that the UFL was at markedly lower elevation, reflecting cold conditions. 
During the late Pleistocene, the low charcoal influx, i.e. below 50710 particles $/ \mathrm{cm}^{2} / \mathrm{yr}$ for both counted fractions (Fig. 4), indicates that fire is rare and suggests the absence of human activity in the study area. Absence or relatively low occurrence of fire during the glacial period has also been documented in other records from southern Ecuador (Brunschön \& Behling 2009, Niemann et al. 2009). Given that fire is the major control on woodland abundance in the Andes (Kessler 1995, Bush et al. 2008), it could be expected that a low frequency of fires might have allowed a much higher proportion of mountain forest in the study area.

\subsubsection{Transition from the Late Pleistocene to the early and mid-Holocene period}

The transition from the late Pleistocene to the early and mid-Holocene period between ca. 12500 and 3600 cal yr BP (zone EC-II), is mostly characterized by the high abundance of mountain forest taxa (60\% of all pollen) with small fluctuations between the LMF and the UMF. The UMF in particular shows a high proportion (55\% of pollen) during the early Holocene (from 11500 to 7800 cal yr BP), whereas during the mid-Holocene (from 7800 to $3600 \mathrm{cal}$ yr BP) the proportion of UMF decreased slightly while the proportion of LMF showed a small increase ( $15 \%$ of pollen). Relatively stable proportions of subpáramo taxa (ca. 15\% of pollen) and páramo vegetation (ca. $30 \%)$ are found during this period. The high abundance of forest taxa coupled with more open subpáramo and páramo taxa suggests that open mountain forest still occupied the study area.

During the transition to the Holocene and early Holocene period (subzone EC-Ila) stable proportions of LMF were present in the pollen record. The UMF was represented mainly by Myrica and Polylepis. Myrica as a pioneer species occurs in degenerated areas and along trails, probably reflecting disturbances in the study area (Marchant et al. 2002, Niemann \& Behling 2009). Polylepis was still present and became even slightly more common during this period (Fig. 3). The Llaviucu record, at the southern part of the Cajas National Park (3180 m elevation) to the north outside of the Andean Depression, shows the highest proportion of Polylepis at the beginning of the Holocene (Colinvaux et al. 1997). Also, the Laguna Natosa Forest record, in the southern part of the Andean Depression (3495 m), shows the highest occurrence of Polylepis during the early and mid-Holocene, between 11660 and 4300 cal yr BP (Rodríguez \& Behling 2012). In addition, there is evidence of stronger distribution of Myrsine and Melastomataceae at the study site. Mysrine is a typical gap species and can be common in upper montane rainforest (Marchant et al. 2002). Melastomataceae is well represented in Ecuadorian secondary forest (Marchant et al. 2002). This stronger distribution probably facilities the expansion of woody vegetation and 
suggests warmer and drier conditions. Stable proportions of subpáramo vegetation was shown in the pollen record. Mainly, the subpáramo was represented by Muehlenbeckia/Rumex, suggesting disturbed areas (Marchant et al. 2002). Slightly lower presence of páramo vegetation is due to the decrease in Cyperaceae, also suggesting drier conditions. This climatic condition coincides with the records of the PNP, e.g. El Tiro and Cerro Toledo, in the central part of the Andean Depression (Niemann \& Behling 2008, Brunschön \& Behling 2009). In addition, a high occurrence of Pteridophyta was established, mainly due to the increase in Cyatheaceae and Jamesonia (páramo fern). This gives an indication of vegetation structure, as ferns may be characteristic of a wet understory but also show high occurrences on open soils after disturbance (Bussmann et al. 2008). The strong decrease of Isoëtes and Cyperaceae reveals that a swamp probably replaced the shallow water pond.

Relatively low values of charcoal influx (i.e. below 33000 particles $/ \mathrm{cm}^{2} / \mathrm{yr}$ and 1000 particle $/ \mathrm{cm}^{2} / \mathrm{yr}$ for small and large fragments respectively) during the early Holocene suggest a scarcity of fires in the study area (Fig. 4).

During the mid-Holocene (subzone EC-IIb), the LMF is mainly characterized by the increased proportion of Alchornea (i.e. from 2 to 5\%). There is a change in the composition of the UMF. A decreased occurrence of Hedyosmum, Myrica and Polylepis, but an increased proportion of Podocarpaceae, Myrsine, Weinmannia and Clethra is found, possibly related to the Holocene thermal optimum which facilitated forest expansion (Hansen et al. 1994, Hansen \& Rodbell 1995, Hansen et al. 2003, Bush et al. 2005, Niemann \& Behling 2008, Niemann et al. 2009). The decrease in the Polylepis population after ca. 4000 cal yr BP (Fig. 3) is probably due to the first higher fire frequency which occurred during this dry period as it is a fire-sensitive tree (Cierjacks et al. 2007). The subpáramo remained stable during the mid-Holocene. Páramo vegetation was still well represented with a high occurrence of Poaceae. In addition, the Pteridophyta is represented by a high presence of Osmunda and Cyatheaceae. It is important to note that the presence of Osmunda often reflects disturbed areas (Brunschön \& Behling 2009).

There is a slight increase in the influx of large particles ( 8600 particle $/ \mathrm{cm}^{2} / \mathrm{yr}$ ) which suggests a first local fire increase at around $4000 \mathrm{cal} \mathrm{yr}$ BP. Since the first stronger presence of human in this region was after $10000 \mathrm{yr} \mathrm{BP}$, according to the Cubilán archaeological record, located in the páramo of Loja at $3100 \mathrm{~m}$ a.s.l. (Valdez 2008). Also an initial strong increase in fire frequency was found in the El Tiro record after ca. 8000 cal yr BP (Niemann \& Behling 2008). 


\subsubsection{Mid- to late Holocene}

During the mid- to late Holocene ( $c a .3600-1380 \mathrm{cal} \mathrm{yr} \mathrm{BP}$ ) the abundant montane forest taxa is split roughly between LMF (ca. 13\%) and UMF (ca. 40-70\%). In addition, subpáramo and páramo taxa became increasingly abundant between 2500 to 1300 cal yr BP, reaching a maximum of $c a$. $30 \%$ and $c a .40 \%$, respectively. Also, higher values of charcoal influx of larger fragments (i.e. from 10000 to 35000 particles $/ \mathrm{cm}^{2} / \mathrm{yr}$ ) are evident after $3300 \mathrm{cal} \mathrm{yr} \mathrm{BP}$, suggesting local fire of anthropogenic origin.

Between ca. 3600 and 2500 cal yr BP (subzone EC-IIla), the LMF taxa are well represented by Moraceae/Urticaceae and Alchornea throughout the period. The UMF expanded strongly, showing a compositional change in the vegetation. There is evidence of a vegetational succession. First with Escallonia, Purdiaea nutans and Clethra, which have the highest values in the record, and later with Melastomataceae, Hedyosmum and finally Weinmannia, suggesting that this vegetational composition possibly constituted a considerable part of the local vegetation. Moreover, subpáramo taxa remain stable. Páramo taxa make up a low proportion mainly because of the decrease of Poaceae. Also Pteridophyta were rare during this period, especially Cyatheaceae. The high proportion of mountain rainforest taxa and comparably low presence of páramo taxa and Pteridophyta may indicate that mountain rainforest vegetation covered the study region and dominated the landscape. Between ca. 2500-1380 cal yr BP (subzone EC-IIIb) the LMF taxa remain stable. The proportion of UMF decreases ( $30 \%$ of pollen), mainly due to the low frequency of Hedyosmum and the absence of Escallonia, Purdiaea nutans and Clethra. The higher proportion of subpáramo taxa, e.g. Asteraceae, between ca. 2000 and1300 cal yr BP, reflects landscape disturbance (Chepstow-Lusty et al. 2003). Like Asteraceae, the presence of Muehlenbeckia/Rumex pollen throughout this period may record disturbance, e.g. agricultural activity (Colinvaux et al. 1997). Páramo-like vegetation is represented primarily by Poaceae, probably due to human activities. Moreover, after ca. 2000 cal yr BP Valeriana became quite common in the study area. In addition, there is the high presence of Osmunda and Huperzia. Especially Huperzia is a pioneer species common on landslides and along road cuts on open sandy soils (Brunschön \& Behling 2009).

In addition, there is evidence of a major influx of larger charcoal fragments after $2000 \mathrm{cal}$ yr BP (Fig. 4) which may reflect local fires of anthropogenic origins, e.g. wood extraction, land use by slash and burn, and hunting (Niemann \& Behling 2008), which may have resulted in grassland 
expansion and forest destruction. An abrupt decrease of arboreal taxa, coupled with high values of Poaceae, Asteraceae, and Pteridophtyta reflects the reaction of the vegetation to increasing fires (Niemann \& Behling 2009).

\subsubsection{Late Holocene}

The late Holocene, from ca. 1380 cal yr BP to the present, was generally characterized by a substantial expansion of páramo taxa, mainly caused by a higher abundance of Poaceae, forming anthropogenic grasslands and a reduction of mountain rainforest to forest patches. However between ca. 1200 and 900 cal yr BP, the UMF expanded, probably due to a forest recovery after a high frequency of fire during the previous period. Moreover, the LMF remained relatively stable during this period. The subpáramo was dominated mainly by Asteraceae.

Between ca. 1380 and $900 \mathrm{cal}$ yr BP (subzone EC-IVa) there is a significant presence of mountain rainforest taxa. Especially certain taxa of UMF vegetation increased markedly, such as Melastomataceae, Escallonia, Purdiaea nutans and Clethra between ca. 1200-900 cal yr BP, which probably reflects a forest recovery. However the LMF taxa decrease slightly. The subpáramo taxa were dominated mainly by Asteraceae. The páramo taxa show a low proportion mainly due to the decrease of Poaceae. In addition, there is evidence of the absence of Pteridophyta spores after ca. 900 cal yr BP. There is low charcoal influx compared with the previous period.

Between ca. $900 \mathrm{cal}$ yr BP and the present (subzone EC-IVb and zone EC-V) the UMF vegetation decreased markedly, mainly Melastomataceae, Escallonia, Purdiaea nutans and Clethra. There is evidence of an expansion of grassland (páramo taxa) mainly caused by the expansion of Poaceae and Cyperaceae (after 500 cal yr BP) which may indicate locally humid conditions (Moscol Olivera \& Hooghiemstra 2010). The occurrence Plantago reflects wet conditions (Bosman et al. 1994, Niemann \& Behling 2008). This indicates a change to a moister and cooler environment.

The increased fire intensity during the wetter late Holocene strongly suggests that frequent fires were of anthropogenic origin. Hence high influx of charcoal accompanies the expansion of páramo species (Colinvaux et al. 1997, Niemann \& Behling 2008, Brunschön et al. 2009). 


\subsection{Comparison of the results with other records}

The new results from El Cristal, located in the northern Andean Depression, is here compared with nearby study sites in and outside the Andean Depression of the northern Andes in Ecuador (Colinvaux et al. 1997, Hansen et al. 2003, Bakker et al. 2008, Niemann \& Behling 2008, 2009; Brunschön \& Behling 2009, Jantz \& Behling 2012), Peru (Hansen et al. 1984, Bush et al. 2005), and Bolivia (Paduano et al. 2003, Williams et al. 2011).

During the late Pleistocene (19 700-12 $500 \mathrm{cal} \mathrm{yr} \mathrm{BP)} \mathrm{a} \mathrm{similar} \mathrm{vegetation} \mathrm{pattern} \mathrm{as} \mathrm{in} \mathrm{El} \mathrm{Cristal} \mathrm{is}$ evident from the pollen records of the PNP located in central part of Andean Depression in southern Ecuador. The Cocha Caranga record, at an elevation of $2710 \mathrm{~m}$, shows higher proportions of the UMF taxa between ca. 14500 and $9700 \mathrm{cal} \mathrm{yr} \mathrm{BP,} \mathrm{indicating} \mathrm{increased} \mathrm{temperatures}$ compared with earlier periods (Niemann \& Behling 2009). The Cerro Toledo record, at $3150 \mathrm{~m}$, suggests a higher occurrence of subpáramo and mountain rainforest vegetation with relatively wet conditions (Brunschön \& Behling 2009). The record from the central Ecuadorian Andes outside the Andean Depression, Lake Surucucho, at $\mathbf{3 1 8 0} \mathrm{m}$, indicates an advance of the treeline during the late glacial period (Colinvaux et al. 1997).

Like the pollen records from the Ecuadorian Andes, the Peruvian and Bolivian Andes records show a similar vegetation pattern to the study area. For example, the Laguna Junin record, at $4100 \mathrm{~m}$ in the central Peruvian Andes, suggests that between 16000 and $12000 \mathrm{yr}$ BP a forest line dominated by Polylepis and Asteraceae covered the plain areas (Hansen et al. 1984). The Laguna de Chochos record, located at an altitude of $3285 \mathrm{~m}$ near the upper forest limit of the eastern Peruvian Andes, suggests that the cloud forest replaced a glacial foreland habitat about 15000 cal yr BP (Bush et al. 2005). Moreover, the Laguna Khomer Kotcha Upper record, at $4153 \mathrm{~m}$ in the eastern Bolivian Andes, shows that before ca. $14500 \mathrm{cal}$ yr BP, warming and relatively moist conditions were evident with an expansion of Polylepis woodland (Williams et al. 2011).

A drier early/mid-Holocene, as recorded in El Cristal between ca. 11500 to $3600 \mathrm{cal}$ yr BP, has been recorded throughout many regions of the northern and central Andes (Marchant et al. 2002). Studies by Bush and Gosling (2012) suggest that sites closest to the equator became dry during the early Holocene (ca. 11000 cal yr BP). Also, the mid-Holocene is characterized by a dry event (ca. 8000-5000 cal yr BP), where a reduction in precipitation in the northern to central Andes is evident (Urrego et al. 2009). However, new past environmental change studies describe this event 
as one of increased drought frequency punctuated with episodic wet events, rather than as a single dry 'event' (Paduano et al. 2003, Bush et al. 2005, Valencia et al. 2010). Especially in the southern Ecuadorian Andes in the PNP, pollen records show relatively warm and dry conditions. As is the case of the record of Laguna Cocha Caranga, which indicates that the early to mid-Holocene was a drier period, shown in the strong decrease of Isoëtes and a marked increase of fire intensity giving rise to the establishment of open grassy vegetation (Niemann \& Behling 2009). Also the El Tiro record, at 2810 m elevation, shows that mountain forest taxa, especially of the UMF, were predominant, with Hedyosmum and Podocarpaceae reflecting a warmer climate (Niemann \& Behling 2008). The Cerro Toledo record shows a gradual change in the vegetation composition. The disappearance of Isoëtes, lower presence of páramo vegetation, and high proportion of subpáramo reflect warmer conditions (Brunschön \& Behling 2009).

Like those from the PNP, the record from the El Cajas National Park (southern Ecuador) Lagunas Chorreras, at $3700 \mathrm{~m}$ altitude outside of the Andean Depression, indicates that the beginning of the Holocene is marked by the expansion of mountain forest. During the Holocene especially Polylepis became commoner, reaching its maximum during the mid-Holocene period (Hansen et al. 2003). Other records from the central and northern Ecuadorian Andes (outside the Andean Depression) show the same vegetation pattern: Laguna Yaguarcocha, at $2200 \mathrm{~m}$ in central Ecuador, with Alnus and Weinmannia as representative taxa (Colinvaux et al. 1988), and Guandera Biological Reserve, $3400 \mathrm{~m}$ in the northernmost region of Ecuador, with a greater occurrence of Hedyosmum (Bakker et al. 2008).

Studies throughout the Ecuadorian Andes as well as in Peru and Bolivia indicate drier conditions during the early/mid-Holocene. The Lagunas de Chochos record suggests that a warm and wet early Holocene was interrupted by a dry period that lasted from ca. 9500 to 7300 cal yr BP, when, consistent with a drier and more fire-disturbed setting, Alnus became an important floral component. Moreover, the Lake Titicaca record, $3810 \mathrm{~m}$ high in the northern portion of the Bolivian Altiplano, reflects a dry phase between ca. 6000 and 4000 cal yr BP, shown by a change in pollen composition that shows sharp declines of Cyperaceae and Isoëtes (Paduano et al. 2003).

During the late Holocene (ca. $1380 \mathrm{cal}$ yr BP to the present) the vegetation composition at the study area El Cristal was somewhat similar to what has been found in the pollen records of the PNP. The Cocha Caranga record shows open grassy areas with forest patches of mainly Weinmannia, Melastomataceae, Myrsine, Clethra and Moraceae/Urticaceae after ca. $1300 \mathrm{cal}$ yr 
BP (Niemann \& Behling 2009). The El Tiro record shows a decrease in upper mountain rainforest and an increase in Melastomataceae, thus suggesting relatively stable subpáramo vegetation (Niemann \& Behling 2008). Unlike El Cristal, the Cerro Toledo record after ca. 1800 cal yr BP shows a slight decrease in páramo and increase in subpáramo, UMF, and LMF taxa, suggesting warmer temperatures (Brunschön \& Behling 2009).

Other records from the southern and northern Ecuadorian Andes show a similar vegetation pattern. Studies by Jantz \& Behling (2012), in the eastern ridge of the western Cordillera in southern Ecuador at $3780 \mathrm{~m}$, indicated that after ca. 2240 cal yr BP vegetation changes suggest a moister and cooler environment, as Plantago rigida became very abundant as well as Ranunculus and Hypericum. Also, the data obtained from the Guandera Biological Reserve indicate an increase of páramo vegetation and a decrease in temperature between 2000 and $800 \mathrm{cal}$ yr BP (Bakker et al. 2008).

\subsection{Summary and Conclusions}

The El Cristal sediment record from the eastern slope of the Cordillera in the Protective Forest Corazón de Oro of southern Ecuador provides a detailed history of the vegetation and fire dynamics since the late Pleistocene. Given the location of the study area in the Andean Depression, local climatic conditions vary considerably, influencing the vegetation structure.

During the late Pleistocene period (ca. 19 750-11 500 cal yr BP) Upper Mountain Forest (UMF) was the main vegetation type at the study area. In particular, there is evidence of the occurrence of Polylepis forests at low elevations in the northern part of the Andean Depression, which does not occur today. Polylepis populations were shifted into the northern part of the Andean Depression from the higher Andean regions. The high occurrence of Isoëtes indicates that the small basin was filled with shallow water. Due to the presence of páramo taxa at lower elevations during the late Pleistocene the upper forest line was at a markedly lower elevation.

The transition from the late Pleistocene to the early and mid-Holocene period between ca. 12500 and $3600 \mathrm{cal}$ yr BP was characterized by small fluctuations between the Lower Mountain Forest (LMF) and the UMF. The relatively stable proportion of subpáramo and páramo taxa suggests that an open mountain forest covered the study area. A substantial decline in Isoëtes indicates that the shallow water pond was probably replaced by a swamp. Hence the relatively high proportion of 
mountain rainforest and low proportion of páramo taxa may reflect warmer conditions. After ca. $4000 \mathrm{cal}$ yr BP, Polylepis forest decreased probably because of an increase in the frequency of fire during this dry period, as it is a fire-sensitive tree. The mid-to late Holocene (ca. 3600-1380 cal yr BP) is characterized by a high occurrence of UMF and a good representation of LMF. The landscape disturbance in the study area is reflected in a higher frequency of Asteraceae, Muehlenbeckia/Rumex, as well as the high presence of Osmunda and Huperzia. The late Holocene, from ca. 1380 cal yr BP to the present, was generally characterized by an expansion of páramo taxa and a low proportion of mountain rainforest. Hence the vegetation changed to an open grassy landscape with forest patches.

Fires, as recorded in small and large charcoal fragments, are found throughout the 19750 years of the core studied, showing that fire is an important ecological factor even under humid conditions such as in the study area. In addition, increased fire intensity during the wetter late Holocene strongly suggests that frequent fires were of anthropogenic origin. However, the first presence of considerable anthropogenic activity is recorded at around 4000 cal yr BP.

\subsection{Acknowledgements}

We thank the Deutsche Forschungsgemeinschaft (DFG) for financial support (BE 2116/8-2) within the research unit FOR 816 "Biodiversity and sustainable management of a megadiverse mountain ecosystem in southern Ecuador". Nele Jantz and Andrés Gerique are thanked for their assistance with the fieldwork. Felix Matt, Jörg Zeilinger and the Team at the ECSF research station are thanked for logistical support.

\subsection{References}

Bakker, J., Moscol, M. \& H. Hooghiemstra. 2008. Holocene environmental change at the upper forest line in northern Ecuador. The Holocene 18: 877-893.

Baldock, J.W. 1982. Geology of Ecuador - explanatory bulletin of the national geological map of the Republic of Ecuador, scale 1:1,000,000. Ministerio de Recursos Naturales y Energéticos, Dirección General de Geología y Minas, Quito.

Beck, E., Bendix, J., Kottke, I., Makeschin, F. \& R. Mosandl (eds.). 2008a. Gradients in a tropical mountain ecosystem of Ecuador. Ecological Studies 198. Springer, Berlin, Heidelberg.

Beck, E., Makeschin, F., Haubrich, F., Richter, M., Bendix, J. \& C. Valerezo. 2008b. The Ecosystem (Reserva Biológica San Francisco). Pp. 1-13 in Beck, E., Bendix, J., Kottke, I., Makeschin, F. \& R. Mosandl (eds.). Gradients in a Tropical Mountain Ecosystem of Ecuador. Ecological Studies 198. Springer, Berlin, Heidelberg. 
Beck, E., Kottke, I., Bendix, J., Makeschin, F. \& R. Mosandl. 2008c. Gradients in a tropical mountain ecosystem - a synthesis. Pp. 451-463 in Beck, E., Bendix, J., Kottke, I., Makeschin, F. \& R. Mosandl (eds.). Gradients in a Tropical Mountain Ecosystem of Ecuador. Ecological Studies 198. Springer, Berlin, Heidelberg.

Behling, H. 1993. Untersuchungen zur spätpleistozänen und holozänen Vegetations- und Klimageschichte der tropischen Küstenwälder und der Araukarienwälder in Santa Catarina (Südbrasilien). Dissertationes Botanicae 206. J. Cramer, Berlin, Stuttgart.

Bendix, J., Rollenbeck, R., Richter, M., Fabian, P. \& P. Emck. 2008. Climate. Pp. 63-73 in Beck, E., Bendix, J., Kottke, I., Makeschin, F. \& R. Mosandl (eds.). Gradients in a Tropical Mountain Ecosystem of Ecuador. Ecological Studies 198. Springer, Berlin, Heidelberg.

Bosman, A., Hooghiemstra, H. \& A. Cleef. 1994. Holocene mire development and climatic change from a high Andean Plantago rigida cushion mire. The Holocene 43: 233-243.

Brunschön, C. \& H. Behling. 2009. Late Quaternary vegetation, fire and climate history reconstructed from two cores at Cerro Toledo, Podocarpus National Park, southeastern Ecuadorian Andes. Quaternary Research 72: 388-399.

Brunschön, C. \& H. Behling. 2010. Reconstruction and visualization of upper forest line and vegetation changes in the Andean depression region of southeastern Ecuador since the last glacial maximum - A multi-site synthesis. Review of Palaeobotany and Palynology 163: 139-152.

Brunschön, C., Haberzettl, T. \& H. Behling. 2010. High-resolution studies on vegetation succession, hydrological variations, anthropogenic impact and genesis of a subrecent lake in southern Ecuador. Vegetation History and Archaeobotany 19: 191-206.

Bush, M.B. \& W.D. Gosling. 2012. Environmental Change in the Humid Tropics and Monsoonal Regions. Pp. 113-140 in Matthews, J.A., Bartlein, P.J., Briffa, K.R., Dawson, A.G., de Vernal, A., Denham, T., Fritz, S.C. \& F. Oldfield (eds.). The SAGE Handbook of Environmental Change. SAGE, London.

Bush, M.B. \& R. Rivera. 2001. Reproductive ecology and pollen representation among neotropical trees. Global Ecology and Biogeography 10: 359-367.

Bush, M.B. \& C. Weng. 2007. Introducing a new (freeware) tool for palynology. Journal of Biogeography 34: 377-380.

Bush, M.B., Colinvaux, P.A., Wiemann, M.C., Piperno, D.R. \& K.B. Liu. 1990. Late Pleistocene temperature depression and vegetation change in Ecuadorian Amazonia. Quaternary Research 34: 330-345.

Bush, M.B., Hansen, B.C.S., Rodbell, D.T., Seltzer, G.O., Young, K.R., Leon, B., Abbott, M.B., Silman, M.R. \& W.D. Gosling. 2005. A 17 000-year history of Andean climate and vegetation change from Laguna de Chochos, Peru. Journal of Quaternary Science 20: 703-714.

Bush, M.B., Hanselman, J.A. \& H. Hooghiemstra. 2007. Andean montane forests and climate change. Pp. 33-54 in Bush, M.B. \& J.R. Flenley( eds.). Tropical rainforest responses to climatic change. Springer Praxis.

Bush, M.B., Silman, M.R., McMichael, C. \& S. Saatchi. 2008. Fire, climate change and biodiversity in Amazonia: A Late-Holocene perspective. Philosophical Transactions of the Royal Society B: 363: 1795-1802.

Bussmann, R.W., Wilcke, W. \& M. Richter. 2008. Landslides as important disturbance regimescauses and regeneration. Pp. 319-330 in Beck E, Bendix J, Kottke I, Makeschin F, \& R. Mosandl (eds.). Gradients in a tropical mountain ecosystem of Ecuador. Ecological Studies 198. Springer, Berlin, Heidelberg.

Chepstow-Lusty, A., Frogley M.R., Bauer, B.S. \& M.B. Bush. 2003. A late Holocene record of arid events from the Cuzco region, Peru. Journal of Quaternary Science 18: 491-502. 
Cierjacks, A., Wesche, K. \& I. Hensen. 2007. Impact of sowing, canopy cover and litter on seedling dynamics of two Polylepis species at upper tree lines in central Ecuador. Journal of Tropical Ecology 23: 309-318.

Cierjacks, A., Rühr, N., Wesche, K. \& I. Hense. 2008. Effects of altitude and livestock on the regeneration of two tree line forming Polylepis species in Ecuador. Plant Ecology 194: 207221.

Cleef, A.M. 1978. Characteristics of neotropical páramo vegetation and its subantarctic relations. Pp. 365-390 in Troll, C. \& W. Lauer (eds.). Geoecological Relations between the Southern Temperate Zone and the Tropical Mountains. Erdwissenschaftliche Forschung XI. Franz Steiner, Wiesbaden.

Colinvaux P., Olson, K. \& K.B. Liu. 1988. Late-glacial and Holocene pollen diagrams from two endorheic lakes of the Inter-Andean plateau of Ecuador. Review of Palaeobotany and Palynology 55: 83-99.

Colinvaux, P.A., Bush, M.B., Steinitz-Kannan, M. \& M.C. Miller. 1997. Glacial and postglacial pollen records from the Ecuadorian Andes and Amazon. Quaternary Research 48: 69-78.

Dodson, C. \& A.H. Gentry. 1991. Biological extinction in western Ecuador. Annals of the Missouri Botanical Garden 78: 273-295.

Ellenberg, H. 1979. Man's influence on tropical mountain ecosystems in South America. Journal of Ecology 67: 401-416.

Emck, P. 2007. A Climatology of South Ecuador - With Special Focus on the Major Andean Ridge as Atlantic-Pacific climate Divide. Dissertation, Universität Erlangen, Nürnberg.

Enrico, L., Funes, G. \& M.R. Cabido. 2004. Regeneration of Polylepis australis Bitt. in the mountains of Central Argentina. Forest Ecology and Management 190: 301-309.

FAO. 2006. Global forest resources assessment 2005, Progress towards sustainable forest management. Food and Agricultural Organization of the United Nations, Rome.

Fægri, K. \& J. Iversen. 1989. Textbook of Pollen Analysis, 4th ed. Wiley, Chichester.

Finsinger W., Tinner W. \& F. Hu. 2008. Rapid and accurate estimates of microcharcoal content in pollen slides. Pp. 121-124 in Charcoals from the past: cultural and palaeoenvironmental implications. Proceedings of the Third International Meeting of Anthracology, CavallinoLecce (Italy), June 28th-July 1st 2004. Archaeopress, Oxford, UK; available from Hadrian Press.

Gentry, A.H. 1995. Patterns of diversity and floristic composition in neotropical montane forests. Pp. 103-26 in Churchill, S.P., Balslev, H., Forero, E. \& J.L. Luteyn. (eds.). Biodiversity and conservation of Neotropical montane forests. New York Botanical Garden, New York.

Gerique A. 2010. Biodiversity as a resource: Plant use and land use among the Shuar, Saraguros, and Mestizos in tropical rainforest areas of southern Ecuador. Dissertation, FriedrichAlexander Universität Erlangen-Nürnberg.

Gosling, W.D. \& M.J. Bunting. 2008. A role for palaeoecology in anticipating future change in mountain regions? Palaeogeography, Palaeoclimatology, Palaeoecology 259: 1-5.

Gosling, W.D., Hanselman, J.A., Knox, C., Valencia, B.G. \& M.B. Bush. 2009a. Long-term drivers of change in Polylepis woodland distribution in the Central Andes. Journal of Vegetation Science 20: 1041-1052.

Gosling, W.D., Mayle, F.E., Tate, N.J. \& T.J. Killeen. 2009b. Differentiation between Neotropical rainforest, dry forest, and savannah ecosystems by their modern pollen spectra and implications for the fossil pollen record. Review of Palaeobotany and Palynology 153: 7085.

Grimm, E.C. 1987. CONISS: a Fortran 77 program for stratigraphically constrained cluster analysis by the method of the incremental sum of squares. Computer and Geosciences 13: 13-35. 
Guffroy, J. 2004. Catamayo precolombino. Investigaciones arqueológicas en la provincia de Loja (Ecuador). IRD editions, Paris.

Hansen, B.C.S. \& D.T. Rodbell. 1995. A Late-Glacial/Holocene pollen record from the eastern Andes of northern Peru. Quaternary Research 44: 216-227.

Hansen, B.C.S., Wright, H.E. \& J.P. Bradbury. 1984. Pollen studies in the Junín area, central Peruvian Andes. Geological Society of America Bulletin 95: 1454-1465.

Hansen, B.C.S., Seltzer, G.O. \& H.E. Wright. 1994. Late Quaternary vegetation change in the central Peruvian Andes. Palaeogeography, Palaeoclimatology, Palaeoecology 109: 263-285.

Hansen, B.C.S., Rodbell, D.T., Seltzer, G.O., León, B., Young, K.R. \& M. Abbott. 2003. Late-glacial and Holocene vegetation history from two sides in the western Cordillera of southwestern Ecuador. Palaeogeography, Palaeoclimatology, Palaeoecology 194: 79-108.

Homeier, J., Werner, F.A., Gradstein, S.R., Breckle, S.-W. \& M. Richter. 2008. Potential vegetation and floristic composition of Andean forests in South Ecuador, with a focus on the RBSF. Pp. 87-100 in Beck, E., Bendix, J., Kottke, I., Makeschin, F. \& R. Mosandl (eds.). Gradients in a Tropical Mountain Ecosystem of Ecuador. Ecological Studies 198. Springer, Berlin, Heidelberg.

Hooghiemstra H. 1984. Vegetation and Climatic History of the High Plain of Bogota, Colombia: a continuous record of the last 3.5 million years. Dissertationes Botanicae 79. Cramer, Vaduz.

Hungerbühler D., Steinmann M., Winkler W., Seward D., Egüez A., Peterson D., Helg U. \& C. Hammer. 2002. Neogene stratigraphy and Andean geodynamics of southern Ecuador. Earth-Science Review 57: 75-124.

Jantz, N. \& H. Behling. 2012. A Holocene environmental record reflecting vegetation, climate, and fire variability at the Páramo of Quimsacocha, southwestern Ecuadorian Andes. Vegetation History and Archaeobotany 21: 169-185.

Jantz, N., Homeier, J., León-Yánez, S., Moscoso, A. \& H. Behling. 2013. Trapping pollen in the tropics - Comparing modern pollen rain spectra of different pollen traps and surface samples across Andean vegetation zones. Review of Palaeobotany and Palynology 193: 57-69.

Kessler, M. 1995. Polylepis-Wälder Boliviens: Taxa, Ökologie, Verbreitung und Geschichte. Dissertationes Botanicae 246. J. Cramer, Berlin.

Kessler, M. 2002. The "Polylepis Problem": where do we stand? Ecotropica 8: 97-110.

Kessler, M. 2006. Bosques de Polylepis. Pp. 110-120 in Moraes, R.M., Øllgaard, B., Kvist, L.P., Borchsenius, F. \& H. Balslev (eds.). Botánica Económica de los Andes Centrales. Universidad Mayor de San Andrés, Plural Editores, La Paz.

Kessler, M., Böhner, J. \& J. Kluge. 2007. Modelling tree height to assess climatic conditions at treelines in the Bolivian Andes. Ecological Modelling 207: 223-233.

Lægaard, S. 1992. Influence of fire in the grass páramo vegetation of Ecuador. Pp. 151-170 in Balslev, H. \& J.L. Luteyn (eds.). Páramo - An Andean ecosystem under human influence. Academic Press, London.

Litherland, M., Aspen J.A. \& R.A. Jemielita. 1994. The metamorphic belts of Ecuador. Overseas Memoir of the British Geological Survey 11: 1-147.

Marchant, R., Almeida, L., Behling, H., Berrio, J.C., Bush, M., Cleef, A., Duivenvoorden, J., Kappelle, M., De Oliveira, P., de Oliveira-Filho, A.T., Lozano-García, S., Hooghiemstra, H., Ledru, M.P., Ludlow- Wiechers, B., Markgraf, V., Mancini, V., Paez, M., Prieto, A., Rangel, O. \& M.L. Salgado-Labouriau. 2002. Distribution and ecology of parent taxa of pollen lodged within the Latin American Pollen Database. Review of Palaeobotany and Palynology 121: 1-75. 
Moscol Oliveira, M. \& H. Hooghiemstra. 2010. Three millennia upper forest line changes in northern Ecuador: Pollen records and altitudinal vegetation distributions. Review of Palaeobotany and Palynology 163: 113-126.

Moscol Oliveira, M., Duivenvoorden, J.F. \& H. Hooghiemstra. 2009. Pollen rain and pollen representation across a forest-páramo ecotone in northern Ecuador. Review of Palaeobotany and Palynology 157: 285-300.

Mutke, J. \& W. Barthlott. 2005. Patterns of vascular plant diversity at continental to global scales. Biologiske Skrifter 55: 521-531.

Myers, N., Mittermeier, R., Mittermeier, C., Fonseca, G. \& J. Kent. 2000. Biodiversity hotspots for conservation priorities. Nature 403: 853-858.

Niemann, H. \& H. Behling. 2008. Late Quaternary vegetation, climate and fire dynamics inferred from the El Tiro record in the southeastern Ecuadorian Andes. Journal of Quaternary Science 23: 203-212.

Niemann H. \& H. Behling. 2009. Late Pleistocene and Holocene environmental change inferred from the Cocha Caranga sediment and soil records in the southeastern Ecuadorian Andes. Palaeogeography, Palaeoclimatology, Palaeoecology 276: 1-14.

Niemann, H. \& H. Behling. 2010. Late Holocene environmental change and human impact inferred from three soil monoliths and the Laguna Zurita multi-proxi record in the southeastern Ecuadorian Andes. Vegetation History and Archaeobotany 19: 1-15.

Niemann, H., Haberzettl, T. \& H. Behling. 2009. Holocene climate variability and vegetation dynamics inferred from the (11,700 cal yr BP) Laguna Rabadilla de Vaca sediment record in the southeastern Ecuadorian Andes. The Holocene 19: 307-316.

Niemann, H., Brunschön, C. \& H. Behling. 2010. Vegetation/modern pollen rain relationship along an altitudinal transect between 1920 and 3185 m a.s.l. in the Podocarpus National Park region, southeastern Ecuadorian Andes. Review of Palaeobotany and Palynology 159: 6980.

Niemann, H., Matthias, I., Michalzik, B. \& H. Behling. 2013. Late Holocene human impact and environmental change inferred from a multi-proxy lake sediment record in the Loja region, southeastern Ecuador. Quaternary International. doi.org/10.1016/j.quaint.2013.03.017

Paduano, G.M., Bush, M.B., Baker, P.A., Fritz, S.C. \& G.O. Seltzer. 2003. A vegetation and fire history of Lake Titicaca since the Last Glacial Maximum. Palaeogeography, Palaeoclimatology, Palaeoecology 194: 259-279.

Peters, T. 2009. Struktur und ökologische Merkmale der oberen Waldgrenze in der Andinen Depression. Dissertation, Universität Erlangen-Nürnberg.

Podwojewski, P., Poulenard, J., Zambrana, T. \& R. Hofstede. 2002. Overgrazing effects on vegetation cover and properties of volcanic ash soil in the páramo of Llangahua and La Esperanza (Tungurahua, Ecuador). Soil Use Management 18: 45-55.

Purcell J. \& A. Brelsford. 2004. Reassessing the causes of decline of Polylepis, a tropical subalpine forest. Ecotropica 10: 155-558.

Rada, F., Azocar, A., Briceno, B., Gonzalez, J. \& C. García-Nuñez. 1996. Carbon and water balance in Polylepis sericea, a tropical treeline species. Tree 10: 218-222.

Ramsay PM. \& E. Oxley. 1996. Fire temperatures and postfire plant community dynamics in Ecuadorian grass Páramo. Vegetatio 124: 129-144.

Renison, D., Cingolani, A.M. \& R. Suarez. 2002. Efectos del fuego sobre un bosquecillo de Polylepis australis (Rosaceae) en las montañas de Córdoba, Argentina (Effects of fire on a Polylepis australis (Rosaceae) woodland in the mountains of Córdoba, Argentina). Revista Chilena de Historia Natural 75: 719-727. 
Richter, M. \& A. Moreira-Muñoz. 2005. Climatic heterogeneity and vegetation diversity in southern Ecuador investigated by phytoindication. Review of Peruvian Biology 12: 217238.

Richter, M., Diertl, K.-H., Peters, T. \& R.W. Bussmann. 2008. Vegetation structures and ecological features of the upper timberline ecotone. Pp. 123-135 in Beck, E., Bendix, J., Kottke, I., Makeschin, F. \& R. Mosandl (eds.). Gradients in a Tropical Mountain Ecosystem of Ecuador. Ecological Studies 198. Springer, Berlin, Heidelberg.

Rodríguez, F. \& H. Behling, H. 2011. Late Holocene vegetation, fire, climate and upper forest line dynamics in the Podocarpus National Park, southeastern Ecuador. Vegetation History and Archaeobotany 20: 1-14.

Rodríguez, F. \& H. Behling. 2012. Late Quaternary vegetation, climate and fire dynamics, and evidence of early to mid-Holocene Polylepis forests in the Jimbura region of the southernmost Ecuadorian Andes. Palaeogeography, Palaeoclimatogoly, Palaeoecology 350-352: 247-257.

Romoleroux, K. 1992. Rosaceae in the páramos of Ecuador. Pp. 85-94 in Balslev, H. \& L.J. Luteyn (eds.). Páramo: An Andean Ecosystem under Human Influence. Academic Press, San Diego.

Sadori L. \& M. Giardini. 2007. Charcoal analysis, a method to study vegetation and climate of the Holocene: The case of Lago di Pergusa (Sicily, Italy). Geobios 40: 173-180.

Sauer W. 1971. Geologie von Ecuador, Mit einem Beitrag: Mineralstoffe von Ecuador von Prof. D. Hannfrit Putzer. Bornträger, Berlin, Stuttgart.

Seltmann, P., Renison, D., Cocucci, A., Hensen, I. \& K. Jung. 2007. Fragment size, pollination efficiency and reproductive success in natural populations of wind-pollinated Polylepis australis (Rosaceae) trees. Flora 202: 547-554.

Schmidt-Lebuhn, A.N., Kessler, M. \& M. Kumar. 2006. Promiscuity in the Andes: species relationships in Polylepis (Rosaceae, Sanguisorbeae) based on AFLP and morphology. Systematic Botany 3: 547-559.

Simpson, B.B. 1979. A Revision of the Genus Polylepis (Rosaceae: Sanguisorbeae). Smithsonian Contribution to Botany 43.

Simpson, B.B. 1986. Speciation and specialization of Polylepis in the Andes. High Altitude Tropical Biogeography. Oxford University Press, Oxford.

Temme, M. 1982. Excavaciones en el sitio precerámico de Cubilan (Ecuador). Miscelánea Antropológica Ecuatoriana 2: 135-165.

UNL (Universidad Nacional de Loja), CINFA (Centro Integrado de Geomática Ambiental) \& Herbario Reinaldo Espinosa. 2006. Estado de Conservación del Área de Bosque y Vegetación Protectora "Corazón de Oro", Loja.

Urrego, D.H., Bush, M.B., Silman, M.R., Correa-Metrio, A.Y., Ledru, M.-P., Mayle, F.E., Paduano, G., \& B.G. Valencia. 2009. Millennial-scale ecological changes in tropical South America since the Last Glacial Maximum. Pp. 283-300 in Vimeux, F., Sylvestre, F. \& M. Khodri (eds.). Past Climate Variability in South America and Surrounding Regions. Developments in Paleoenvironmental Research 14, Springer, Berlin.

Urrego, D.H., Niccum, B.A., La Drew, C.F., Silman, M.R. \& M.B. Bush. 2011. Fire and drought as drivers of early Holocene tree line changes in the Peruvian Andes. Journal of Quaternary Science 26: 28-36.

Valdez F. 2008. Inter-zonal relationships in Ecuador. Pp. 865-888 in Silverman, H. \& W.H. Isbell (eds.). Handbook of South American Archeology. Springer, New York.

Valencia, B.G., Urrego, D.H., Silman, M.R. \& M.B. Bush. 2010. From ice age to modern: a record of landscape change in an Andean cloud forest. Journal of Biogeography 37: 1637-1647. 
Villota, A., León-Yánez, S. \& H. Behling. 2012. Vegetation and environmental dynamics in the Páramo of Jimbura region in the southeastern Ecuadorian Andes during the late Quaternary. Journal of South American Earth Sciences 40: 85-93.

Webster, G. 1995. The panorama of neotropical cloud forests. Pp. 53-78 in Churchill, S.P., Balslev, H., Forero, E. \& J.L. Luteyn (eds.). Biodiversity and Conservation of Neotropical Montane Forests. The New York Botanical Garden, New York.

Weng, C., Bush, M.B. \& A.J. Chepstow-Lusty. 2004. Holocene changes of Andean alder (Alnus acuminata) in highland Ecuador and Peru. Journal of Quaternary Science 19: 685-691.

Weninger, B., Jöris, O. \& U. Danzeglocke. 2004. Calpal: The Cologne radiocarbon Calibration and Palaeoclimate research package. URL: http:// www.calpal.de.

Whitlock C. \& C. Larsen. 2001. Charcoal as a fire proxy. Pp. 75-98 in Smol J.P., Birks H.J.B. \& W.M Last (eds.). Tracking environmental change using lake sediments. Kluwer, Dordrecht.

Wille, M., Hooghiemstra, H., Hofstede, R., Fehse, J. \& J. Sevink. 2002. Upper forest line reconstruction in a deforested area in northern Ecuador based on pollen and vegetation analysis. Journal of Tropical Ecology 18: 409-440.

Williams, J.J., Gosling, W.D., Brooks, S.J., Coe, A.L. \& S. Xu. 2011. Vegetation, climate and fire in the eastern andes (Bolivia) during the last 18,000 years. Palaeogeography, Palaeoclimatogoly, Palaeoecology 312 (1-2): 115-126.

Wunder, S. 1996. Deforestation and the uses of wood in the Ecuadorian Andes. Mountain Research and Development 16: 367-382.

Wunder, S. 2000. The economics of deforestation: the example of Ecuador. St. Martin, New York.

Ybert, J.P. 1988. Apports de la palynologie à la connaissance de I'histoire du lac Titicaca (BoliviePérou) au cours du Quaternaire récent. Travaux de la Section Scientifique et Technique, Institute Française de Pondichery XXV: 139-150. 



\section{CHAPTER 3}

\section{Late Glacial and Holocene environmental change inferred from the páramo of Cajanuma in the Podocarpus National Park, southern Ecuador.}

Andrea Villota ${ }^{1,2}$ \& Hermann Behling ${ }^{2}$

${ }^{1}$ Herbario QCA, Escuela de Ciencias Biológicas, Pontificia Universidad Católica del Ecuador, QuitoEcuador

${ }^{2}$ Department of Palynology and Climate Dynamics, Albrecht von Haller Institute for Plant Sciences, University of Göttingen, 37073 Göttingen, Germany

Caldasia 36(2): xx-xx. 2014 


\section{Abstract}

To reconstruct the environmental history including vegetation, fire and climate dynamics, from the Cajanuma valley area (3285 m elevation) in the Podocarpus National Park, southern Ecuador, we address the following major research question: (1) How did the mountain vegetation developed during the late Glacial and Holocene? (2) Did fire played an important control on the vegetation change and was it natural or of anthropogenic origin?

Palaeoenvironmental changes were investigated using multiple proxies such as pollen, spores, charcoal analyses and radiocarbon dating. Pollen data highlight that during the late Glacial and transition to the early Holocene (ca. 16 000-10 500 cal yr BP) herb páramo was the main vegetation type around the study area, while subpáramo and mountain rainforest were low represented. The early and mid-Holocene (ca. 10500 to $5600 \mathrm{cal}$ yr BP) is marked by high abundance of páramo during the early Holocene followed by a slight expansion of mountain forest during the mid-Holocene. During the mid- to late Holocene (ca. 5600-1200 cal yr BP) there is a significant presence of páramo and subpáramo while Lower Mountain Forest decreased substantially. Though, Upper Mountain Forest remained relatively stable during this period. The late Holocene, from ca. 1200 cal yr BP to present, was characterized by páramo; although, mountain forest and subpáramo presented significantly abundance compared to the previous periods.

Fires became frequent since the late Holocene. The marked increased local and regional fire intensity during the wetter late Holocene strongly suggests that were of anthropogenic origin.

During the late Glacial and early Holocene, the upper forest line was located at low elevations; but shifted slightly upslope to higher elevations during the mid-Holocene.

\section{Keywords}

Palaeoecology, páramo, late Glacial, Holocene, climate and fire dynamics 


\section{Resumen}

Para reconstruir la historia ambiental, incluyendo la dinámica de la vegetación, el fuego y el clima, del área del valle de Cajanuma (3.285 m de altitud) en el Parque Nacional Podocarpus, sur del Ecuador, nos planteamos las siguientes preguntas de investigación: (1) ¿Cómo fue el desarrollo de la vegetación de montaña durante el último glacial y el Holoceno? (2) ¿Acaso el fuego jugó un control importante sobre el cambio de la vegetación y fue este de tipo natural o de origen antropogénico?

Cambios paleoambientales se investigaron mediante múltiples proxy tales como polen, esporas, los análisis de carbón y la datación por radiocarbono. Datos del polen resaltan que durante la parte final del último glacial y la transición al Holoceno temprano (ca. 16,000-10,500 cal yr BP) el páramo herbáceo fue el principal tipo de vegetación alrededor de la zona de estudio, mientras que subpáramo y el bosque montano se encuentran con una baja representación. El Holoceno temprano y medio (ca. 10.500 a 5.600 años cal BP) se encuentran marcados por la alta abundancia de páramo, durante el Holoceno temprano, seguido de una ligera expansión del bosque montano, durante el Holoceno medio. Durante el Holoceno medio y tardío (ca. 5.600-1.200 años cal BP) hay una presencia significativa de páramo y subpáramo mientras que el bosque montano bajo disminuyó sustancialmente. Sin embargo, el bosque montano alto se mantuvo relativamente estable durante este período. El Holoceno tardío (ca. 1200 años AP hasta la actualidad) se caracterizó por vegetación de páramo, aunque, el bosque montano y subpáramo presentaron una abundancia significativa en comparación con los períodos anteriores.

Los incendios se hicieron frecuentes a partir del Holoceno tardío. El aumento marcado de la intensidad del fuego local y regional durante Holoceno tardío, período húmedo, sugiere fuertemente que eran de origen antropogénico.

Durante el Último Glacial y Holoceno temprano, la línea superior del bosque se encontró en elevaciones bajas, ésta subió a elevaciones más altas durante el Holoceno medio.

\section{Palabras Clave}

Paleoecología, páramo, Último Glacial, Holocene, dinámica del clima y fuego 


\subsection{Introduction}

The tropical northern Andes are among the hot spots of global vascular plant diversity due to their high structural and geological diversity. Especially, the Ecuadorian Andes harbour the most species rich ecosystems on earth (Barthlott et al. 2005; Rangel 2006). Among these bioma, the most characteristic one is páramo, due to its floristically unique, which is found above the upper forest line. The páramo is thought to have expanded downslope, while extensive burning and grazing prevented forest recovery. Some researchers suggest that the grass páramo below $4300-4100 \mathrm{~m}$ represents, at least partially, secondary vegetation in formerly forested areas (Lægaard 1992). It is especially subject to overgrazing, burning and cultivation, which leads to reduction of biodiversity (Podwojewski et al. 2002). Moreover, Ecuador currently suffers the highest deforestation rate of 198000 ha year ${ }^{-1}$ between 1990 and 2005 (FAO 2006), because of the long occupation history and increasing human impact during last decades.

In this context, natural vegetation regeneration and sustainable management, as well as conservation of less degraded areas is urgently needed. The knowledge of palaeoecological conditions is very important to understand the natural composition and dynamics of modern ecosystems for proper management and conservation. Despite the need, of this knowledge only a limited number of palaeoecological studies are available from the Ecuadorian Andes (Bush et al. 2007). The available pollen records for the southeastern Andes, Andean Depression, were provided by the German-Ecuadorian Research Unit (www.tropicalmountainforest.org) focusing on the Podocarpus National Park (PNP) area and its surroundings (Niemann et al. 2013; Rodríguez \& Behling 2012; Villota et al. 2012). Several investigations from sites between 2000 and $3300 \mathrm{~m}$ a.s.l. provide reconstructions of the environmental history, mostly of the northern PNP (Brunschön \& Behling 2009; 2010; Jantz et al. 2013; Niemann \& Behling 2008; 2009; 2010; Niemann et al. 2009; Rodríguez \& Behling 2011).

In this paper, we present the investigation results of a core from the Cajanuma valley area in the western slope of the PNP, southern Ecuadorian Andes. Our main objective is the reconstruction of the local environmental history including vegetation, fire and climate dynamics in an attempt to identify mechanisms of past ecosystem change and human impact during the late Glacial. For that reason in this study we want to address the following main questions: (1) How did the vegetation develop at Cajanuma during the late Glacial and Holocene? (2) Did fire provide an important 
control over the vegetation and was it natural or anthropogenic? (3) How dynamic or stable were the UFL during the late Glacial and Holocene in the upper region of the PNP?

\subsection{The Study region}

\subsubsection{Location}

The study area, Cajanuma, is located at the western slope of the eastern cordillera (Cordillera Real) in the Podocarpus National Park (PNP), southeastern Ecuadorian Andes (Fig. 1). The eastern Andean Cordillera is mainly formed by Paleozoic metamorphic rocks (Baldock 1982). The basin margins contain conglomerates of metamorphic debris, semipelites, quartzites and black phylites with some granitic intrusions (Litherland et al. 1994).

Particularly, the Andes of southern Ecuador are part of the Andean depression region (Depression of Giron-Cuenca in southern Ecuador and Huancabamba in northern Peru), where the highest peaks reach no more than $4000 \mathrm{~m}$ a.s.I., and active volcanoes and glaciers are absent (Schubert \& Clapperton 1990). However, indications of Pleistocene glaciations are found. During the Last Glacial Maximum (LGM) lower moraine limits at 3750-3500 m a.s.l. in the eastern Ecuadorian Andes were estimated (Heine 2000), as well as, cirque lakes (remnants of the latest glaciations) between 2900 and 3400 m a.s.I. in the central PNP (Emck 2007).

The core analyzed "Cajanuma valley" (CV) was derived from a small peat bog, $30 \mathrm{~m}$ in diameter, located at $3285 \mathrm{~m}$ elevation ( $4^{\circ} 08^{\prime} 59^{\prime \prime}$ South, $79^{\circ} 09^{\prime} 25^{\prime \prime}$ West). The surrounding landscape is characterised by páramo with small forest patches at lower slopes. The area around the study site is not disturbed. 


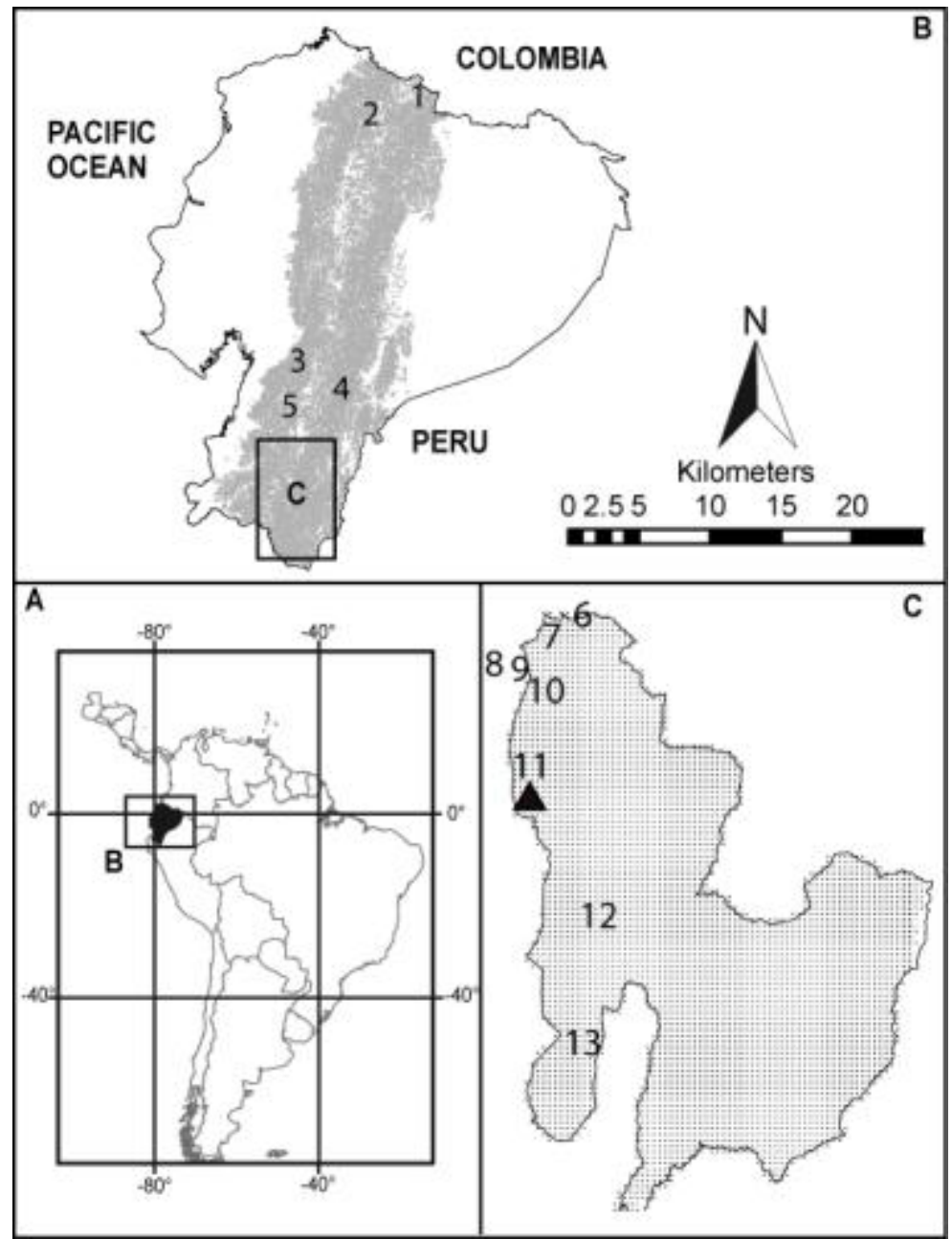

Figure 1. A. Map of Ecuador in South America. B. Map of the Andes of Ecuador, showing the location of the different studies sites. 1, Guandera Biological Reserve; 2, Laguna Yaguarcocha; 3, Lagunas Chorreras; 4, Lake Surucucho; 5, Tres Lagunas. C. Map of Podocarpus National Park and surrounding area, showing the location of the different studies sites. 6, Laguna Zurita; 7, El Tiro; 8, Laguna Daniel Álvarez; 9, Laguna Campana; 10, Cocha Caranga; 11, Valle Pequeño; Cajanuma valley; 12, Laguna Rabadilla de Vaca; 13, Cerro Toledo.

\subsubsection{Climate}

Inside the PNP at $3100 \mathrm{~m}$ a.s.l., rainfall up to $6000 \mathrm{~mm} \mathrm{a}^{-1}$ was measured (Emck 2007; Bendix et al. 2008). The main rainy season lasts from April to August (austral winter), although rainfall is high throughout the year. On average, 9-10 humid months are recorded for the western slopes and temperature varies according to the time of day and season (Bendix et al. 2008). The coldest period of the year is generally the main rainy season. In the Cajanuma area the mean annual 
temperature registered is ca. 6.9 으 $\mathrm{C}$ and the annual precipitation rate is about $5700 \mathrm{~mm}$ (Emck 2007).

\subsubsection{Vegetation}

The most appropriate vegetation description by Homeier et al. (2008) classifies four different escarpment vegetation types in the PNP, which are relevant for our investigation area: lower and upper mountain rainforest, subpáramo and páramo. The coring site is situated in the páramo (including shrub and herb páramo) between ca. 3100-3700 $\mathrm{m}$ a.s.l.

According to Homeier et al. (2008) and additional information provided by Lozano et al. (2003), the lowest vegetation type is the lower mountain rainforest (LMF) between ca. 1300-2100 m a.s.l. with canopy heights of $30 \mathrm{~m}$. Undisturbed communities of this type can be found particularly on steep slopes with 30 으 to 50 inclination, as well as up to ca. $2300 \mathrm{~m}$ at the bottom of windprotected river valleys. Characteristic species are Alzetea verticillata, Cedrela montana, Graffenrieda miconioides, Heliocarpus americanus, Mikania sp., Morus insignis, Myrcianthes sp. and Piper sp. The upper mountain rainforest (UMF) is located between ca. 2100-2700 m a.s.I. and the canopy attains heights up to $25 \mathrm{~m}$. Some of the main key species are Clethra revoluta, Clusia sp., Dioicodendron dioicum, Hedyosmum racemosum, Ilex rimbachii, Macrocarpaea revoluta, Myrica pubescens, Myrsine andina, Myrsine coriacea, Podocarpus oleifolius, Prumnopitys montana, Purdiaea nutans and species of Weinmannia. At upper elevation between ca. 2700-3100 $\mathrm{m}$ a.s.l. the elfin-forest or subpáramo vegetation occurs. This vegetation type forms the upper forest line ecotone with a canopy height of 6-8 m. Characteristic species are, e.g. Brachyotum rotundifolium, Clethra ovalifolia, Gaultheria reticulata, Gaiadendron punctatum, Graffenrieda harlingii and Hesperomeles lanuginosa. The páramo (including shrub and herb páramo) occurs in the crest regions of the Cordillera Real above the upper forest line between ca. 3100 and $3700 \mathrm{~m}$ a.s.I. Páramo vegetation is characterised by plants with a maximum height of $2 \mathrm{~m}$. Some key species are Arcytophyllum setosum, Blechnum cordatum, Calamagrostis macrophylla, Chusquea neurophylla, Gynoxis buxifolia, Halenia weddelliana, Huperzia kuesteri, Ilex andicola, Monnina arbuscula, Neurolepis nana, Niphogeton dissecta, Oxalis spiralis, Puya eryngioides, Puya maculate, Rhynchospora vulcani and Valeriana microphylla.

The present vegetation around the PNP is partially degraded due to deforestation and land conversion into pastures and cultivations (Beck et al. 2008). Currently, disturbance is primarily 
restricted to the surrounding areas and some border zones; a reason why the Podocarpus National Park still widely possesses well-protected natural vegetation including the study area of Cajanuma.

\subsection{Material and Methods}

\subsubsection{Sediment extraction}

The "Cajanuma valley" (CV) sediment core was taken with a Russian Corer. The total length of the recovered core is $180 \mathrm{~cm}$. Sections of $50 \mathrm{~cm}$ length were placed in splitted PVC tubes covered with plastic film and stored under dark and cold $\left(+4{ }^{\circ} \mathrm{C}\right)$ conditions at Georg-August-University of Göttingen before processing.

For accelerator mass spectrometer (AMS) radiocarbon dating, four subsamples containing organic material were submitted to the University of Erlangen-Nürnberg (Germany). The ${ }^{14} \mathrm{C}$ dates were calibrated using the curve SHCal04. 14C SH terrestrial dataset of the Calib 6.0 software (Stuiver et al. 2005)

\subsubsection{Palynological analysis}

For palynological analysis, the CV core was sampled at four $\mathrm{cm}$ intervals along the core, resulting in 41 subsamples of $0.5 \mathrm{~cm}^{3}$ each. All subsamples were processed using the standard pollen analytical methods (Fægri \& Iversen 1989). One tablet of exotic Lycopodium clavatum spores, containing $18583 \pm 762$ spores, was added to each sample before treatment as a marker for calculation of pollen and charcoal concentration as well as influx. A minimum of 300 pollen grains was counted for each sample. The pollen sum includes pollen of herbs, shrubs, trees and indeterminate taxa and excludes fern spores and pollen of aquatic taxa. The spores of Pteridophyta, Isoëtes and Sphagnum were counted and quantified as percentages based on the pollen sum.

The identification of pollen and spores is based on the reference published by Hooghiemstra (1984), as well as electronic pollen keys of Ecuador, kept at the department of Palynology and Climate Dynamics, and the South American Pollen Database (Bush \& Weng 2007). Reference collections of recent material, held at the Department of Palynology and Climate Dynamics in Göttingen, were also used. They contain about 3000 neotropical taxa (Behling 1993) and ca. 620 Ecuadorian taxa, respectively. Identified taxa were classified into ecological groups that correspond to the prevailing vegetation types: Lower Mountain Rainforest (LMF), Upper Mountain 
Rainforest (UMF), Subpáramo, Páramo and Pteridophyta. The pollen types that could not be identified were grouped in the indeterminate taxa. For charcoal analysis was used the technique developed by Finsinger et al. (2008), which estimated that charcoal particles correspond to the concentration of Lycopodium clavatum spores (marker). Charcoal particles were counted up to a total count of 100 Lycopodium clavatum spores. The counted charcoal particles were separated in two groups of different particle sizes $(10-50 \mu \mathrm{m}$ and $50->100 \mu \mathrm{m})$ to be able to give more detailed information about the fire history (Sadori \& Giardini 2007). Fragments between 10 and 50 $\mu \mathrm{m}$ indicate regional fires, and fragments 50 - >100 $\mu \mathrm{m}$ local fire (Whitlock \& Larsen 2001).

\subsubsection{Data analysis}

The software TILIA was used for data calculation of percentages, sums, as well as pollen and charcoal concentration and influx. TILIAGRAPH software was used to illustrate the data, as well as stratigraphy and the calibrated and uncalibrated dates (Grimm 1987). The program CONISS was used to conduct a cluster analysis of the pollen data which were included in the pollen sum to generate a dendrogram (Grimm 1987), helping to identify the pollen zones.

\subsection{Results}

\subsubsection{Stratigraphy}

The $180 \mathrm{~cm}$ long peat bog sediment core from Cajanuma Valley (CV) consists of clay and organic material. Between 180 and $160 \mathrm{~cm}$ core depth clayey material is dominant with a dark/light greyish colour. From 160 to the top of the core the sediments are more compact and there is presence of organic material. Between 160 and $130 \mathrm{~cm}$ the organic material is highly decomposed and has a dark brown colour. Between 130 and $100 \mathrm{~cm}$ is found less decomposed organic material with presence of a few fine roots and has a light brownish colour. Between 100 and $35 \mathrm{~cm}$ the organic material is little decomposed with many plant remains and has a brown colour. Between 35 and $0 \mathrm{~cm}$ little decomposed organic material with humus layer is present and has a light brown colour. A detailed description of the stratigraphic units is given in Table 1.

Table 1. Stratigraphic description of the sediment core Cajanuma Valley (CV)

\begin{tabular}{ll}
\hline Depth (cm) & Description \\
\hline $0-10$ & Not decomposed plant material, with plant remains (roots)-humus layer
\end{tabular}




$$
\begin{array}{ll}
\text { 10-35 } & \text { Very little decomposed plant material, with plant remains (roots), light } \\
\text { brown coloured } \\
35-50 & \text { Little decomposed organic material with roots, light brown coloured } \\
50-75 & \text { Little decomposed organic material with little roots, light brown coloured } \\
75-100 & \text { Little decomposed organic material, dark brown coloured } \\
100-125 & \text { Less decomposed organic material, light brownish coloured } \\
125-130 & \text { Less decomposed organic material, dark brownish coloured } \\
130-160 & \text { Highly decomposed organic material, dark brownish coloured } \\
160-175 & \text { Clayey material, dark-greyish coloured } \\
175-180 & \text { Clayey material, with little stones; light-greyish coloured }
\end{array}
$$

\subsubsection{Chronology and pollen zonation}

Four AMS radiocarbon dates (Table 2) were performed at the AMS laboratory at the University of Erlangen/Nürnberg, Germany, providing the chronological control of the sediment core from Cajanuma valley (CV). Extrapolation of the dates suggests that the base of the core has an age of ca. $16000 \mathrm{cal}$ yr BP that probably reflects the beginning of sediment accumulation.

The series of four AMS dates shows a consistent age-depth model (Fig. 2), which indicates that sediments accumulated continuously without any gaps since the late Glacial. The average sediment accumulation rate is $0.69 \mathrm{~mm} \mathrm{yr}^{-1}$. In detail it is $0.04 \mathrm{~mm} \mathrm{yr}^{-1}$ (16 000 to $10500 \mathrm{cal} \mathrm{yr} \mathrm{BP}$ ), $0.04 \mathrm{~mm} \mathrm{yr}^{-1}$ (10 500 to $5600 \mathrm{cal} \mathrm{yr} \mathrm{BP),} 0.11 \mathrm{~mm} \mathrm{yr}^{-1}$ (5600 to $1200 \mathrm{cal} \mathrm{yr} \mathrm{BP),} 0.71 \mathrm{~mm} \mathrm{yr}^{-1}$ (1200

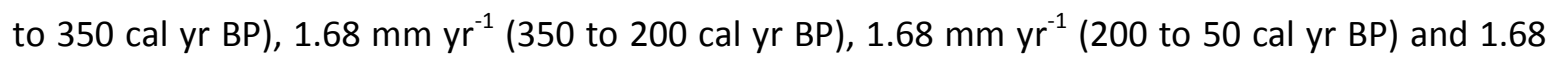
$\mathrm{mm} \mathrm{yr}^{-1}$ (50 to $-59 \mathrm{cal} \mathrm{yr} \mathrm{BP}$ ). The CONISS cluster analysis and major changes in the pollen assemblages suggest five main pollen zones (CV-I to CV) with subzones (CV-Va-c).

Table 2. List of AMS radiocarbon ${ }^{14} \mathrm{C}$ dates and calibrated ages from the Cajanuma Valley (CV) core using the curve SHCal04. 14C SH terrestrial dataset of the Calib 6.0 software.

\begin{tabular}{lllll}
\hline Lab. Code & Depth $(\mathrm{cm})$ & Dated Material & ${ }^{14}$ C age (yr BP) & 1- $\sigma(\mathrm{cal}$ yr BP) \\
\hline Erl-16087 & $80-81$ & Organic material & $378 \pm 48$ & $402 \pm 90$ \\
Erl-16586 & $104-105$ & Organic material & $1538 \pm 107$ & $1396 \pm 218$
\end{tabular}




\begin{tabular}{lllll} 
Erl-16086 & $135.5-136.5$ & Organic material & $4803 \pm 66$ & $5515 \pm 82$ \\
Erl-16587 & $160-161$ & Wood & $9933 \pm 86$ & $11440 \pm 153$ \\
\hline
\end{tabular}

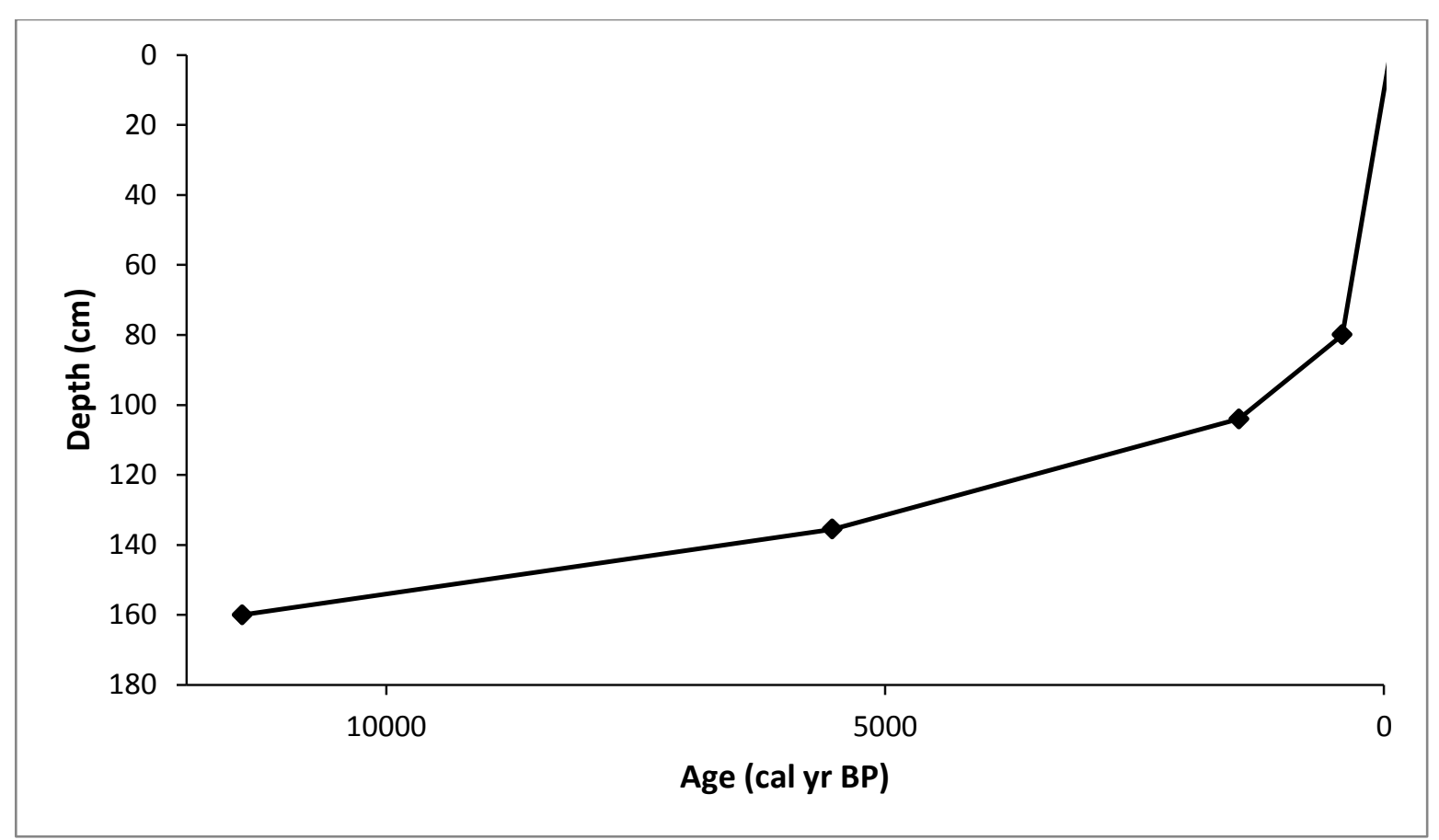

Figure 2. Age-depth model (core depth in $\mathrm{cm} / \mathrm{cal}$ yr BP) for the Cajanuma Valley (CV) core based on 4 radiocarbon dates. 


\subsubsection{Description of the pollen diagram}

A detailed pollen percentage diagram displays 21 different pollen taxa with a representation of $>2 \%$ out of 77 pollen types and two spores types with a representation of $>2 \%$ out of eleven identified (Fig. 3). The summary percentage diagram (Fig. 4) shows the pollen and spores grouped into the vegetation types: Lower Mountain Rainforest (LMF), Upper Mountain Rainforest (UMF), Subpáramo, Páramo and Pteridophyta (without Isoëtes), Sphagnum and concentration and influx of pollen and charcoal particles.

Pollen concentration and influx vary between $25000-530000$ grains $/ \mathrm{cm}^{3}$ and between 250-12 000 grains $/ \mathrm{cm}^{2} / \mathrm{yr}$, respectively. The charcoal concentration of the two counted fraction vary

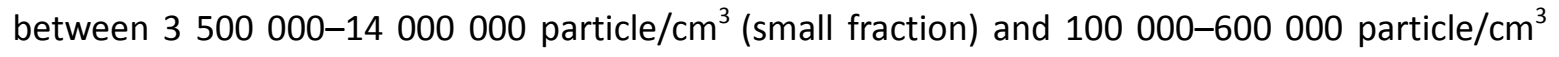
(large fraction). The charcoal influx for both counted fractions varies between 40 000-1 200000 particle $/ \mathrm{cm}^{2} / \mathrm{yr}$ (small fractions) and between 100-95 000 particle $/ \mathrm{cm}^{2} / \mathrm{yr}$ (large fraction).

Zone CV-I (180-156 cm; ca. 16 000-10 500 cal yr BP, six samples), is characterized by low proportion of LMF pollen taxa (10\%) mainly due to low values of Moraceae/Urticaceae (7\%) and Acalypha (1\%). UMF taxa (15-20\%) are mainly represented by Hedyosmum (9\%), which presents the highest value of the record in this zone, Myrsine, Podocarpaceae, Symplocos, Weinmannia and Alnus acuminata (2-3\%). Subpáramo pollen taxa show stable values $(20 \%)$, mainly by Asteraceae $(10 \%)$ and Melastomataceae (5\%). This zone is marked by relatively high values of páramo taxa $(60 \%)$, especially by Poaceae $(40 \%)$ and Cyperaceae pollen (10\%). Also, pollen of Gentianaceae (5\%) presents the highest values of the record. In this zone Pteridophyta spores (20-25\%) are mainly represented by Huperzia (15-20\%), which presents the highest value of the record in this zone. Isoëtes spores (up to 25\%), which are not included in the sum of Pteridophyta, are very frequent in this zone.

Zone CV-II (156-136 cm; ca. 10 500-5600 cal yr BP, five samples). LMF taxa show stable values $(10 \%)$ by Moraceae/Urticaceae (7\%) and the presence of Acalypha (2\%). Proportions of UMF pollen taxa increase slightly (25\%) by Myrsine and Podocarpaceae (2-3\%). Symplocos pollen represents the highest values (6-10\%) of the record in this zone. Alnus acuminata values decrease (0\%). Pollen of subpáramo taxa increases slightly (20\%) at the top of the zone mainly by Melastomataceae (10\%). Páramo taxa decreased slightly from 60 to $50 \%$, especially due to lower representation of Poaceae (30\%). However, Plantago rigida pollen has higher values (8\%) in this 
zone. Pteridophyta group strongly decrease (10\%); mainly due to the low representation of Huperzia spores (3\%). In this zone Isoëtes spores occur with lower values (5\%).

Zone CV-III (136-96 cm; ca. 5600-1200 cal yr BP, eleven samples), is characterized by low representation of LMF pollen (6\%), due to the lowest values of Moraceae/Urticaceae pollen (3\%). Proportion of UMF taxa decreased slightly (15\%), mainly due to low percentages of Symplocos (4\%). Subpáramo pollen taxa show a stable proportion (25\%) such as Asteraceae (15\%) and Melastomataceae (6\%). Ericaceae are represented by higher values (5\%) in this zone. Páramo pollen taxa are frequent and show highest values in this zone (65\%), mainly due to Poaceae (35\%) and Valeriana (10\%). Compared to the previous zone, Pteridophyta show stable proportions (10\%), mainly due to Huperzia (5\%); also by spores of Cyatheaceae (3\%) which present the highest value of the record. In this zone spores of Isoëtes are absent. Proportion of Sphagnum spores (5\%) increases in this zone.

Zone CV-IV (96-72 cm; ca. 1200-350 cal yr BP, six samples), is marked by a slightly higher representation of LMF pollen (11\%), e.g. Moraceae/Urticaceae (6\%) and Acalypha (2\%) compared to the previous zone. UMF taxa increase slightly $(20 \%)$ at the top of the zone; mainly by Weinmannia (4\%) and Alnus acuminata (4\%) at the top of the zone. A slight increase is found in pollen of Celtis (3\%). However, Podocarpaceae pollen represents lower values (1\%) in this zone. Subpáramo pollen taxa decreased from 25 to $15 \%$, especially due to lower representation of Asteraceae (8\%) and Ericaceae (3\%). Páramo taxa vary between 65 and $55 \%$, especially due to lower values of Poaceae pollen (30\%) at the bottom of the zone. Valeriana pollen presents the highest values $(10 \%)$ of the record at the bottom of this zone. Compared to the previous zone Pteridophyta decreased strongly (5\%) and Sphagnum spores (35\%) present the highest values of the record.

Subzone CV-Va (72-44 cm; ca. 350-200 cal yr BP, seven samples), is characterized by a stable representation of LMF taxa, mainly due to Moraceae/Urticaceae (4-7\%); also Acalypha and Piperaceae with (2\%). UMF taxa reach highest values between 20 and $28 \%$ of the record, mainly due to pollen of Myrsine (4\%) and Symplocos and Alnus acuminata with (5\%). Percentages of subpáramo taxa increase slightly, such as Ericaceae (4\%). Highest representation of pollen of Melastomataceae (15\%) and Hypericum (4\%) is found in this subzone. Compared to the precious zone proportion of páramo taxa decreased (45\%), mainly due to Poaceae $(20 \%)$ and Valeriana (4\%). Pollen of Cyperaceae represents higher proportion (10\%) at the bottom of this subzone. In 
this subzone Pteridophyta spores (2\%) decreased mainly by the low presence of Huperzia spore (1\%) and the absence of Cyatheaceae spores. Isoëtes values increase slightly (7\%) at the top of this subzone. Spore of Sphagnum (15\%) decrease at this subzone.

Subzone CV-Vb (44-20 cm; ca. 200-50 cal yr BP, three samples), shows a stable proportion of LMF pollen (11\%). UMF taxa remain stable (20\%); however Weinmannia show higher values (5\%) in this subzone. Subpáramo pollen shows the highest amounts within this subzone, especially by Asteraceae (15\%) and Ericaceae pollen (5\%). Compared to the previous subzone, páramo taxa show stable percentage, especially by Poaceae (20\%). In this subzone Pteridophyta show stable values (2\%).

Zone CV-Vc (24-0 cm; ca. 50 cal yr BP to -59 cal yr BP, three samples), is characterized by slightly increase proportion of LMF pollen taxa; mainly Moraceae/Urticaceae taxa slightly increase (6$10 \%$ ) at the top of this zone. UMF taxa remain stable between 20 and 25\%; however Celtis show highest values $(5 \%)$ of the record in this zone. Subpáramo taxa show the lowest values of the record (13\%), mainly by Asteraceae, Melastomataceae (5\%) and Ericaceae (1\%). Compared to the previous subzone, pollen of páramo increase from 40 to $50 \%$. This is mainly due to increasing values of Poaceae (25\%), Cyperaceae (15\%) and Valeriana (6\%). Compared to the previous subzone Pteridophyta spores show stable values (2\%). Isoëtes value increase slightly (14\%). Proportion of Sphagnum spores (25\%) slightly increased at the bottom of this zone. 


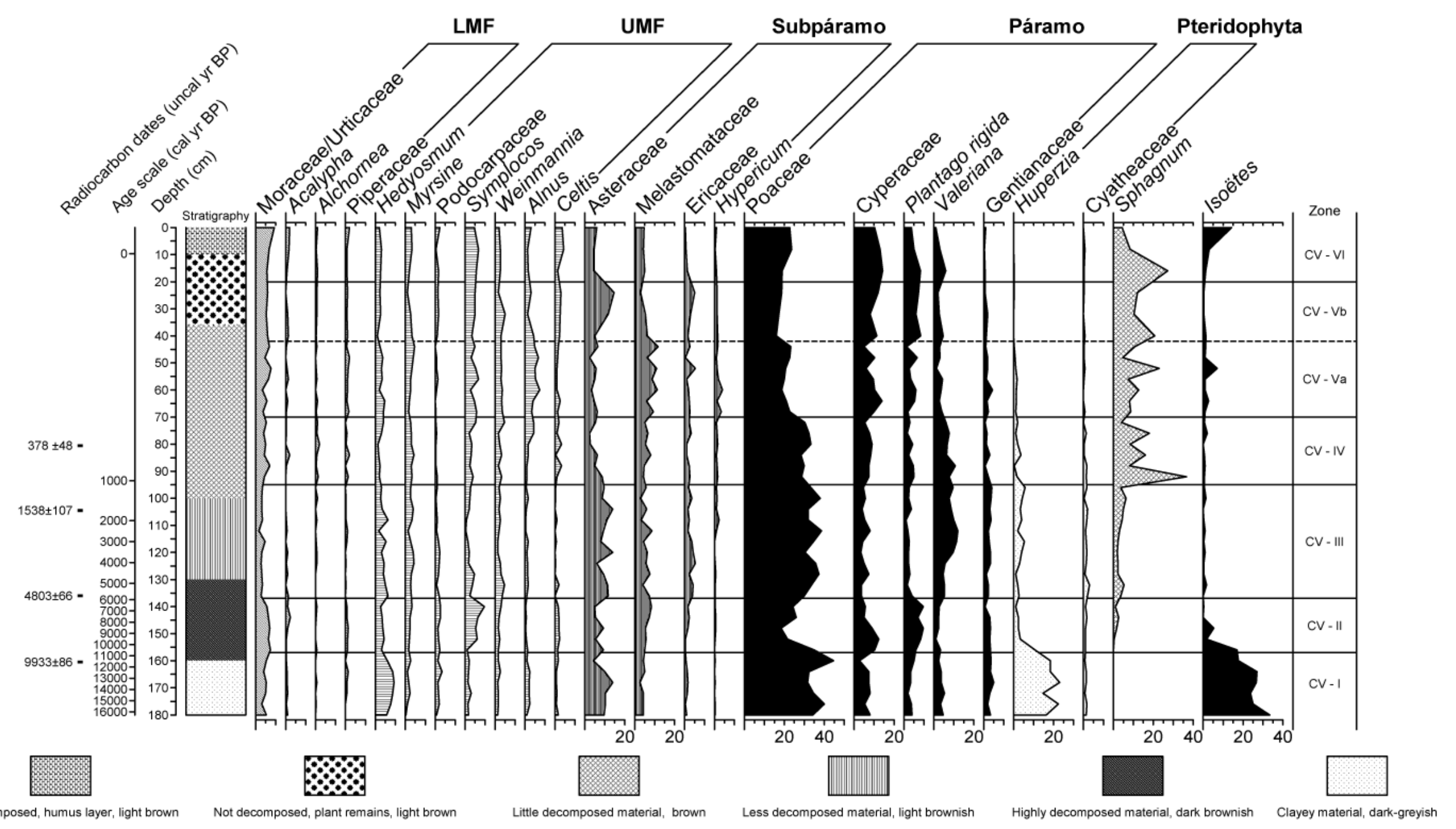

Figure 3. Pollen percentage diagram of the Cajanuma Valley (CV) core showing selected fossil pollen and spore taxa grouped into Lower Mountain Rainforest (LMF), Upper Mountain Rainforest (UMF), Subpáramo, Páramo and Pteridophyta. 


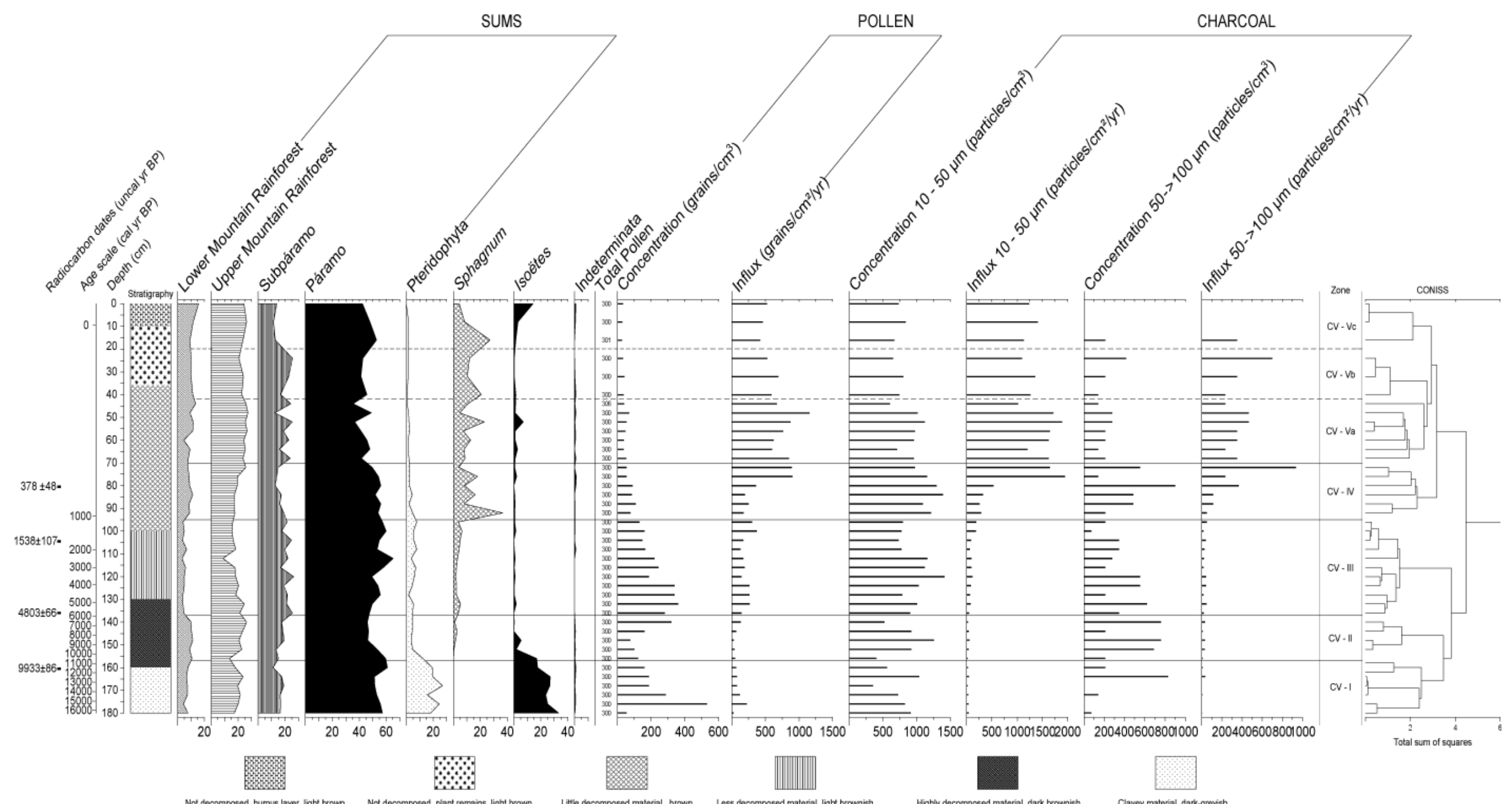

Figure 4. Summary pollen percentage diagram of the Cajanuma Valley (CV) core showing radiocarbon dates (uncal yr BP), age scale (cal yr BP), vegetation groups, pollen sum, pollen concentratin and influx, charcoal concentration and influx, and the CONISS dendrogram. 


\subsection{Interpretation and discussion of the environmental record}

During the Last Glacial Maximum (LGM), most Andean glaciers moved down slope and reached their lowermost positions at about $3000 \mathrm{~m}$ in the eastern Andes of Colombia, Ecuador and northern Peru (Rodbell 1994). Lower glacier margins are estimated at ca. $3100 \mathrm{~m}$ for the PNP region, with glaciers terminating at elevations of ca. 2750-2800 m (Rozsypal 2000). At the end of the LGM, the volume of glaciers decreased creating moraines, lakes and bogs. The moraine frontier at the PNP is found between 2800 and 3350 m elevation, after the glacial retreat deposits accumulated at the study site at about 16000 cal yr BP.

\subsubsection{Late Glacial and transition to the early Holocene}

The pollen record from Cajanuma valley (CV) indicates that herb páramo was the main vegetation type around the study area during the recorded period from ca. 16 000-10 $500 \mathrm{cal}$ yr BP (zone CVI), while the subpáramo and mountain rainforest were low represented. The low presence of mountain forest taxa is probably related to low temperatures at that time which did not allow the development of mountain forest near the study site.

During this period, is also recorded the low pollen input into the basin with presence of clayey material; which could reflect that the páramo vegetation was sparse and forest occurred in some distance to the coring site. Such conditions of low local productivity coupled with input from long distance dispersal serves to elevate a few anemophilous pollen types in the percentage data, yielding proportions that do not reflect local vegetation (Hansen et al. 1984).

Pollen of Lower Mountain Rainforest (LMF) taxa (e.g., Moraceae/Urticaceae, Alchornea and Acalypha) tends to be over-represented due to wind transport to higher elevations (Jantz et al. 2013). At Laguna Baja in northern Peru over representation of forest taxa (e.g., Moraceae/Urticaceae) in páramo samples is attributed to low pollen productivity of local plants at high elevations resulting in higher values of long distance wind transported pollen (Hansen \& Rodbell 1995). Main components of the Upper Mountain Rainforest (UMF) were Hedyosmum, Podocarpaceae and Alnus acuminata. The occurrence of Hedyosmum, which is abundant during this period, indicates relatively wet conditions. Representation of Alnus acuminata pollen in páramo was observed also in the superpuna of the Junín area in central Peru and was assumed due to long distance transport (Hansen et al. 1984). The subpáramo at CV was dominated by 
shrubby vegetation composed of Asteraceae and Melastomataceae. The herb páramo was rich in Poaceae, Cyperaceae and Gentianaceae, reflecting cool conditions, associated with a high presence of Huperzia and Isoëtes. The occurrence of Pteridophyta and high values of Isoëtes suggest wetter conditions. Isoëtes mostly occurs submerged in páramo lakes and is sensitive to strong frosts (Bosman et al. 1994). It indicates that there must have been a shallow water body at the study site. Similarly, cooler climates are indicated by the occurrence of treeless vegetation during glacial times in the southern Ecuadorian Andes (Colinvaux et al. 1997). Also in southwestern Ecuadorian Andes (3700 m elevation), studies indicate for the late Glacial period (17 000-11 000 cal yr BP), a herb páramo surrounded the area, reflecting colder and moister climatic conditions (Hansen et al. 2003).

During the late Glacial and transition to the early Holocene, the low charcoal influx indicates rare fire and suggests the absence of human activity in the study area.

\subsubsection{Early to mid-Holocene}

The early to the mid-Holocene period between ca. 10500 to 5600 cal yr BP (zone CV-II), is marked by gradual change indicated by high abundance of páramo vegetation during the early Holocene, followed by a slight expansion of mountain forest into higher elevations and a partial replacement of páramo during the mid-Holocene. Páramo vegetation began to decrease while subpáramo and mountain rainforest increased (9000-5600 cal yr BP).

During this period stable proportion of LMF was shown in the pollen record; but there is evidence of a slight increase of Acalypha, which probably reflects slow and continuous increasing temperatures. UMF vegetation increases slightly mainly by the strong increase of Symplocos taxa. Also by, Myrsine and Podocarpaceae. Nevertheless, Hedyosmum starts to decline in abundance ca. $10500 \mathrm{cal}$ yr BP. The stable proportion of LMF and the increase of UMF suggest an establishment of mountain rainforest vegetation and a rise in temperature during this period. Subpáramo was dominated mainly by Asteraceae and Melastomataceae. Relatively high proportion of páramo was reached during this period, mainly by high abundance of Cyperaceae and Plantago rigida. The frequent occurrences of $P$. rigida and Cyperaceae indicate locally humid conditions (Moscol Oliveira \& Hooghiemstra 2010). In particular P. rigida constitutes cushion bogs at high elevation (3000-5200 m) in grass páramo (Bosman et al. 1994; Niemann \& Behling 2008). Pteridophyta were rare during this period, Huperzia decreased during the transition from the late Pleistocene- 
Holocene period (Hansen et al. 2003). However, abundance of Cyatheaceae slightly increased during this period. Also, Isoëtes became rare at the study site. In the Cajas National Park (western Ecuadorian Andes), the pattern was similar, the early Holocene showed warmer conditions than at present (Colinvaux et al. 1997; Hansen et al. 2003). At Fuquene Lake (eastern Colombian Andes), very humid conditions are suggested during the early Holocene (Vélez et al. 2006). At Laguna Chochos and Laguna Baja (eastern Peruvian Andes) a warm and wet condition is shown by the arrival of cloud forest taxa to both sites at 11500 cal yr BP (Hansen \& Rodbell 1995; Bush et al. 2005). Also, studies in the west and central Andes region of Ecuador, Peru and Bolivia in general show a trend of a relative warm and dry mid-Holocene (Hansen et al. 2003; Paduano et al. 2003; Weng et al. 2006).

Relatively low values of charcoal influx during the early and mid-Holocene suggest rare fires in the study area.

\subsubsection{Mid- to late Holocene}

During the mid- to late Holocene (ca. 5600-1200 cal yr BP, zone CV-III), the LMF decreased, in particular Moraceae/Urticaceae. Whereas the LMF decreased, the UMF presence remained relatively stable; with a particular high abundance of Weinmannia and Hedyosmum and a marked lower occurrence of Symplocos. However, it has to be considered that Weinmannia and Hedyosmum are anemophilous taxa (Hansen \& Rodbell 1995; Weng et al. 2004). Anemophilus taxa are overrepresented in pollen spectra (Moscol Oliveira et al. 2009; Jantz et al. 2013). Subpáramo vegetation expanded due to the higher representation of Asteraceae, Ericaceae and Hypericum at the top of the zone; probably suggesting higher moisture conditions (Marchant et al. 2002). Hypericum is also a good proxy for the existence of landscape disturbance (Brunschön \& Behling 2009). The páramo vegetation expanded, it was dominated mainly by Poaceae and Gentianaceae with increasing proportions of Valeriana; suggesting a change to cooler and wetter conditions. The marked decrease of Plantago rigida and increase of Poaceae might indicate that grass páramo surrounded the study site. In addition, the high presence of Huperzia and Cyatheaceae suggests wetter conditions.

Fires were slightly frequent during the mid- to late Holocene period. There is evidence of a slight increased influx of smaller charcoal fragments after 5600 cal yr BP. Studies from lake Titicaca and the surrounding altiplano as well as southern Ecuador suggest that once the mid-Holocene 
drought ends, human populations expand rapidly and are engaged in landscape modification (Brenner et al. 2001; Niemann \& Behling 2008).

\subsubsection{Late Holocene}

The late Holocene since ca. 1200 cal yr BP (zone CV-IV to CV-V), was generally characterized by páramo vegetation, but mountain forest and subpáramo were similar or slightly stronger presented compared to the previous periods. Pteridophyta were almost absent during this period.

Between ca. 1200-350 cal yr BP (zone CV-IV) the LMF increased slightly, mainly by the increased proportion of Alchornea and Piperaceae. However, as mention before pollen of LMF taxa (e.g., Moraceae/Urticaceae, Alchornea, Acalypha and Piperaceae) tends to be over-represented due to wind transport to higher elevations. The UMF increased slightly and was represented mainly by high occurrence of Alnus acuminata and Celtis. Alnus acuminata grows along river beds and follows landslides as a pioneer (Marchant et al. 2002). The presence of $A$. acuminata can be a result of anthropogenic disturbances (Weng et al. 2004), rather than by climatic changes. A. acuminata and Celtis are also a component of successional forests after human disturbance (Marchant et al. 2002). The subpáramo remained relatively stable during this period. Páramo vegetation was still well represented with a high occurrence of Poaceae and Valeriana; suggesting cooler and wetter conditions. Higher abundance of Sphagnum appeared during this period. Sphagnum moss probably reflects the formation of the peat bog the study area.

Between ca. 350-50 cal yr BP (subzone CV-Va and CV-Vb), the LMF vegetation remain stable. Slightly higher presence of UMF vegetation is due to the slight increase of Symplocos, Weinmannia and Alnus acuminata. Subpáramo vegetation slightly increased, mainly by higher proportion of Asteraceae and Melastomataceae. Especially, Asteraceae may reflect landscape disturbance (Chepstow-Lusty et al. 2003). Slightly lower presence of páramo vegetation is due to the lower occurrence of Poaceae and Valeriana. However, Cyperaceae slightly increased; suggesting cooler and wetter conditions. Sphagnum presence remained stable. Also, high occurrence of Isoëtes is recorded. Persistent humid conditions are suggested by high occurrences of Cyperacae and Isoëtes.

Between ca. 50 cal yr BP-to the present (subzone CV-Vc) LMF and UMF remained stable. Subpáramo vegetation decreased slightly due to lower presence of mainly Asteraceae and almost absence of Ericaceae. Poaceae together with Cyperaceae dominated in the herb páramo until 
modern times; reflecting cooler conditions where modern vegetation as well as modern climatic conditions became established.

In addition, there is evidence of a major influx of larger charcoal fragments after $1200 \mathrm{cal} \mathrm{yr}$ BP which may reflect local fires of anthropogenic origin. Since, the first stronger presence of human in this region was after $10000 \mathrm{yr}$ BP according to the Cubilán archaeological record, located about $100 \mathrm{~km}$ north of Loja at $3100 \mathrm{~m}$ of altitude (Valdez 2008). During the late Holocene human influence is reported throughout the Andes (Hansen et al. 2003; Bush et al. 2005; Weng et al. 2006). Nevertheless, it is important to point out that for the last years there is no evidence of local fires; as mention above disturbance is primarily restricted to the surrounding areas and the study site is since the last years well-protected.

\subsubsection{Upper forest line (UFL) changes}

The Upper Forest Line (UFL) dynamics is mainly reflected by fluctuations in the proportion of upper mountain rainforest (UMF) and subpáramo vegetation. During the late Glacial and transition to the early Holocene, from ca. 16 000-10 $500 \mathrm{cal} \mathrm{yr} \mathrm{BP,} \mathrm{the} \mathrm{high} \mathrm{proportion} \mathrm{of} \mathrm{páramo} \mathrm{taxa}$ comparably with the low presence of mountain rainforest and subpáramo indicate that páramo vegetation extensively covered the area and dominated the landscape. This probably reflects a downslope shift of UFL in the study area. During the LGM, the UFL position in the Podocarpus National Park (PNP) area was at least ca. $700 \mathrm{~m}$ lower in the northernmost PNP area compared to today (Brunschön \& Behling 2010).

Likewise, the late Glacial period, during the early Holocene, (10 500-9000 cal yr BP), herb páramo was the main vegetation type around the study area. Subpáramo vegetation and mountain rainforest were low represented. Suggesting that, the UFL position was still low. On the contrary, within the whole PNP area, the UFL seems to have shifted upslope in the range of ca. 100-150 m (Brunschön \& Behling 2010). During the mid- Holocene, (9000-5600 cal yr BP), a relatively high increase of mountain rainforest and subpáramo shrubs and trees is observed. Páramo vegetation was represented by a lower occurrence. This probably, suggests a shift of UFL to higher elevations. A ca. 400 m upslope is reconstructed for the PNP by Brunschön \& Behling (2010).

During the mid- to late Holocene, (5600-1200 cal yr BP), the significant presence of páramo taxa comparably with the relatively low presence of mountain rainforest probably represents a downslope shift of UFL in the study area. 
Between ca. 1200-350 cal yr BP high proportion of páramo taxa comparably with the low presence of mountain rainforest and subpáramo indicate a downslope shift of UFL in the study area. However, the suggested lower UFL should be interpreted in the context of local fires. Higher frequency of fires probably lowered the UFL position.

Between ca. $350 \mathrm{cal}$ yr BP to present, the páramo vegetation seems to have been slightly depressed, while the mountain forest and subpáramo vegetation slightly expanded; suggesting an upslope of the UFL. The UFL shifted upslope to the highest elevations of ca. $2800 \mathrm{~m}$ a.s.I. in the PNP (Brunschön \& Behling 2010).

\subsection{Comparison with other records from the Podocarpus National Park}

The Cajanuma valley record, located at 3285 m elevation in the western slope of the PNP, will be compared to close by study sites: El Tiro Pass (2811 m a.s.l.; $15 \mathrm{~km}$ north of the site), Cocha Caranga (2710 m a.s.l., ca. 10 km north), Valle Pequeño (3244 m a.s.l., ca. 3 km), Laguna Rabadilla de Vaca (3312 m a.s.l., ca. $15 \mathrm{~km}$ south of the study site) and Cerro Toledo (3150 m a.s.l., ca. $30 \mathrm{~km}$ south) (Fig. 1).

During the late Glacial and transition to the early Holocene (16 000-10 $500 \mathrm{cal}$ yr BP), a similar vegetation pattern as in Cajanuma valley is evident from the pollen record of El Tiro Pass which indicated grass páramo vegetation, mainly composed of Poaceae and Plantago reflecting cold and moist conditions (Niemann \& Behling 2008). Nevertheless, a pollen record of Cocha Caranga suggests higher proportions of the UMF between ca. 14500 to $9700 \mathrm{cal}$ yr BP, indicating increased temperatures compared to earlier periods (Niemann \& Behling 2009). Also the Cerro Toledo record suggests higher occurrence of subpáramo and mountain rainforest vegetation with relative wet conditions (Brunschön \& Behling 2009).

A similar vegetation pattern, as in Cajanuma valley, during the early Holocene, (10 500-9000 cal yr BP), was recorded in El Tiro Pass between, 11200 to 8900 cal yr BP, which indicates slowly warming conditions with a relatively low increase in mountain rainforest and subpáramo shrubs and trees (Niemann \& Behling 2008). In the Laguna Rabadilla de Vaca record, between ca. 11 700$8990 \mathrm{cal}$ yr BP, it is evident that herb páramo was the main vegetation type associated with a high number of ferns, reflecting cool and relatively wet climatic conditions (Niemann et al. 2009). 
A drier mid-Holocene, as recorded in Cajanuma valley between ca. 9000 to 5600 cal yr BP, has been recorded throughout the PNP. As is the case of the El Tiro record in which, between ca. 8900 to $3300 \mathrm{cal}$ yr BP, UMF was predominant and a succession of Hedyosmum and Podocarpaceae took place (Niemann \& Behling 2008). The Laguna Cocha Caranga record indicates that the early to mid-Holocene was a drier period by the strong increase of Cyperaceae and Isoëtes and a marked increase of fire intensity (Niemann \& Behling 2009). The strong increase of Weinmannia indicates warmer climatic conditions, between ca. 8990-3680 cal yr BP, at the Laguna Rabadilla de Vaca record (Niemann et al. 2009). The Cerro Toledo record between 6900 to $4700 \mathrm{cal}$ yr BP shows a gradual change in the vegetation composition. The lower presence of páramo vegetation and high proportion of subpáramo; reflects warmer conditions (Brunschön \& Behling 2009).

During the late Holocene (ca. $1200 \mathrm{cal}$ yr BP to the present) the vegetation composition at the study area is somewhat similar to what has been found in the pollen records of the PNP. The Cocha Caranga record shows open grassy areas with forest after ca. 1300 cal yr BP (Niemann \& Behling 2009). The record of Cerro Toledo after ca. 1800 cal yr BP shows a slight decrease in páramo and increase in subpáramo, UMF, and LMF suggesting warmer temperatures (Brunschön \& Behling 2009). Also, the El Tiro record shows an increase of Melastomataceae, thus suggesting relatively stable subpáramo vegetation (Niemann \& Behling 2008). Also, the Valle Pequeño record suggests a higher representation of mountain forest after ca. 1630 cal yr BP (Rodríguez \& Behling 2011).

\subsection{Summary and Conclusions}

- The Cajanuma valley sediment core at $3285 \mathrm{~m}$ a.s.l. present a detailed palaeoenviromental record from the late Glacial to the Holocene, on the western slope of Podocarpus National Park of the eastern Cordillera in southern Ecuador.

- During the recorded late Glacial period and transition to the early Holocene, since ca. 16000 to 10500 cal yr BP, herb páramo, rich in Poaceae, Cyperaceae and Gentianaceae, associated with a high presence of Huperzia and Isoëtes, indicates cool and wet conditions.

- During the early to mid-Holocene from ca. 10500 to 5600 cal yr BP, there was a high abundance of páramo vegetation followed by a slight expansion of mountain forest into higher elevations and a partial replacement of treeless páramo. High proportion of páramo was 
reached, mainly by high abundance of Plantago rigida, suggesting relatively cold conditions. The upper mountain rainforest (UMF) developed slightly due to higher abundance of Symplocos taxa. The high occurrence of the UMF at the coring site and the stronger decomposition of the organic material suggest relatively warm and also somewhat drier conditions.

- During the mid- to late Holocene (ca. 5600-1200 cal yr BP) there is a marked presence of páramo and subpáramo, while LMF decreased markedly. Even though, UMF presence remained relatively stable.

- The late Holocene period since 1200 cal yr BP was generally characterized by páramo vegetation. Even though, mountain forest and subpáramo presented a high abundance compared to the previous periods.

- Fires were rare during the late Glacial and became slightly frequent during the mid- late Holocene after $5600 \mathrm{cal}$ yr BP. But since the late Holocene at about $1200 \mathrm{cal}$ yr BP, fires became more common, reflecting fires of anthropogenic origin.

- The Upper Forest Line (UFL) dynamics fluctuated since the late Glacial to the Holocene. During the late Glacial, the UFL occurred at much lower elevation than today. During the early Holocene, the UFL position remains low. However, at the mid- to late Holocene, the UFL shifted upslope to higher elevations where it is today.

\subsection{Acknowledgements}

We thank the Deutsche Forschungsgemeinschaft (DFG) for financial support (BE 2116/8-2) within the research unit FOR 816 "Biodiversity and sustainable management of a megadiverse mountain ecosystem in southern Ecuador". Corinna Brunschön and Fernando Rodríguez are thanked for their assistance in the fieldwork. The team of ESCF is thanked for logistical support.

\subsection{References}

BALDOCK, J.W. 1982. Geology of Ecuador-explanatory bulletin of the national geological map of the Republic of Ecuador, scale 1:1,000,000. Ministerio de Recursos Naturales y Energéticos, Dirección General de Geología y Minas, Quito, pp. 11.

BARTHLOTT, W., J. MUTKE, D. RAFIQPOOR, G. KIER \& H. KREFT. 2005. Global centers of vascular plant diversity. Nova Acta Leopold 92:61-83 
BECK, E., F. MAKESCHIN, F. HAUBRICH, M. RICHTER, J. BENDIX \& C. VALEREZO. 2008. The Ecosystem (Reserva Biológica San Francisco). In: Beck, E., Bendix, J., Kottke, I., Makeschin, F., Mosandl, R., (Eds.), 2008. Gradients in a Tropical Mountain Ecosystem of Ecuador. Ecological Studies 198. Springer, Berlin, Heidelberg, pp. 1-13.

BENDIX, J., R. ROLLENBECK, M. RICHTER, P. FABIAN \& P. EMCK. 2008. Climate. In: Beck, E., Bendix, J., Kottke, I., Makeschin, F., Mosandl, R., (Eds.), Gradients in a Tropical Mountain Ecosystem of Ecuador. Ecological Studies 198, Springer, Berlin, Heidelberg, pp. 63-73.

BEHLING, H. 1993. Untersuchungen zur spätpleistozänen und holozänen Vegetations- und Klimageschichte der tropischen Küstenwälder und der Araukarienwälder in Santa Catarina (Südbrasilien). Dissertationes Botanicae 206, J. Cramer, Berlin, Stuttgart.

BOSMAN, A., H. HOOGHIEMSTRA \& A. CLEEF. 1994. Holocene mire development and climatic change from a high Andean Plantago rigida cushion mire. The Holocene 43, 233-243.

BRENNER, M., D.A. HODELL, J.H. CURTIS, M.F. ROSENMEIER, M.W. BINFORD \& M.B. ABBOTT. 2001. Abrupt climate change and Pre-Columbian cultural collapse. In Interhemispheric Climate Linkages, Markgraf V (ed.). Academic Press: San Diego, CA; 87-104.

BRUNSCHÖN, C. \& H. BEHLING. 2009. Late Quaternary vegetation, fire and climate history reconstructed from two cores at Cerro Toledo, Podocarpus National Park, southeastern Ecuadorian Andes. Quaternary Research 72, 388-399.

BRUNSCHÖN, C. \& H. BEHLING. 2010. Reconstruction and visualization of upper forest line and vegetation changes in the Andean depression region of southeastern Ecuador since the last glacial maximum - A multi-site synthesis. Review of Palaeobotany and Palynology $163,139-152$.

BUSH, M.B., B.C.S. HANSEN, D.T. RODBELL, G.O. SELTZER, K.R. YOUNG, B. LEON, M.B. ABBOTT, M.R. SILMAN \& W.D. GOSLING. 2005. A 17 000-year history of Andean climate and vegetation change from Laguna de Chochos, Peru. Journal of Quaternary Science 20, 703714.

BUSH, M.B. \& C. WENG. 2007. Introducing a new (freeware) tool for palynology. Journal of Biogeography 34, 377-380.

BUSH, M.B., J.A. HANSELMAN \& H. HOOGHIEMSTRA. 2007. Andean montane forests and climate change. In: Bush, M.B., Flenley, J.R. (Eds.), Tropical rainforest responses to climatic change. Springer, Praxis, pp. 33-54.

CHEPSTOW-LUSTY, A., M.R. FROGLEY, B.S. BAUER M.B. BUSH. 2003. A late Holocene record of arid events from the Cuzco region, Peru. Journal of Quaternary Science 18, 491-502.

COLINVAUX, P.A., M.B. BUSH, M. STEINITZ-KANNAN \& M.C. MILLER. 1997. Glacial and postglacial pollen records from the Ecuadorian Andes and Amazon. Quaternary Research 48, 69-78.

EMCK, P. 2007. A Climatology of South Ecuador - With Special Focus on the Major Andean Ridge as Atlantic-Pacific climate Divide. Dissertation, Universität Erlangen, Nürnberg.

FAO. 2006. Global forest resources assessment 2005, Progress towards sustainable forest management. Food and Agricultural Organization of the United Nations, Rome.

FAEGRI, K. \& J. IVERSEN. 1989. Textbook of Pollen Analysis, 4th ed. Wiley, Chichester, pp. 328.

FINSINGER W., W. TINNER \& F. HU. 2008. Rapid and accurate estimates of microcharcoal content in pollen slides. Pp. 121-124 in Charcoals from the past: cultural and palaeoenvironmental implications. Proceedings of the Third International Meeting of Anthracology, CavallinoLecce (Italy), June 28th-July 1st 2004. Archaeopress, Oxford, UK; available from Hadrian Press.

GRIMM, E.C. 1987. CONISS: a Fortran 77 program for stratigraphically constrained cluster analysis by the method of the incremental sum of squares. Computer and Geosciences 13, 13-35. 
HANSEN, B.C.S., H.E. WRIGHT \& J.P. BRADBURY. 1984. Pollen studies in the Junín area, central Peruvian Andes. Geological Society of America Bulletin 95, 1454-1465.

HANSEN, B.C.S. \& D.T. RODBELL. 1995. A Late-Glacial/Holocene pollen record from the eastern Andes of northern Peru. Quaternary Research 44, 216-227.

HANSEN, B.C.S., D.T. RODBELL, G.O. SELTZER, B. LEÓN, K.R. YOUNG \& M. ABBOTT. 2003. Late-glacial and Holocene vegetation history from two sides in the western Cordillera of southwestern Ecuador. Palaeogeography, Palaeoclimatology, Palaeoecology 194, 79-108.

HEINE, K. 2000. Tropical South America during the Last Glacial Maximum: evidence from glacial, periglacial and fluvial records. Quaternary International 72, 7-21.

HOOGHIEMSTRA, H. 1984. Vegetation and Climatic History of the High Plain of Bogota, Colombia., Vaduz: J. Cramer.

HOMEIER, J., F.A. WERNER, S.R. GRADSTEIN, S.W. BRECKLE \& M. RICHTER. 2008. Potential vegetation and floristic composition of Andean forests in South Ecuador, with a focus on the RBSF. In: Beck, E., Bendix, J., Kottke, I., Makeschin, F., Mosandl, R., (Eds.), Gradients in a Tropical Mountain Ecosystem of Ecuador. Ecological Studies 198, Springer, Berlin, Heidelberg, pp. 87-100.

JANTZ, N., J. HOMEIER, S. LEÓN-YÁNEZ, A. MOSCOSO \& H. BEHLING. 2013. Trapping pollen in the tropics - Comparing modern pollen rain spectra of different pollen traps and surface samples across Andean vegetation zones. Review of Palaeobotany and Palynology 193, 57-69

LAEGAARD, S. 1992. Influence of fire in the grass páramo vegetation of Ecuador. In: Balslev, H. \& Luteyn, J.L. (eds.) Páramo - An Andean ecosystem under human influence. Academic Press, London. pp. 151-170.

LITHERLAND, M., J.A. ASPEN \& R.A. JEMIELITA. 1994. The metamorphic belts of Ecuador. Overseas Memoir of the British Geological Survey, 11, 1-147.

LOZANO, P., T. DELGADO \& Z. AGUIRRE. 2003. Estado actual de la flora endémica exclusive y su distribucion en el Occidente del Parque Nacional Podocarpus. Funbotanica y Herbario y Jardin Botanico. Loja, Ecuador.

MARCHANT, R., L. ALMEIDA, H. BEHLING, J.C. BERRIO, M. BUSH, A. CLEEF, J. DUIVENVOORDEN, M. KAPPELLE, P. DE OLIVEIRA, A.T. DE OLIVEIRA-FILHO, S. LOZANO-GARCÍA, H. HOOGHIEMSTRA, M.P. LEDRU, B. LUDLOW-WIECHERS, V. MARKGRAF, V. MANCINI, M. PAEZ, A. PRIETO, O. RANGEL \& M.L. SALGADO-LABOURIAU. 2002. Distribution an ecology of parent taxa of pollen lodged within the Latin American Pollen Database. Review of Palaeobotany and Palynology 121, 1-75.

MOSCOL OLIVEIRA, M., J.F. DUIVENVOORDEN \& H. HOOGHIEMSTRA. 2009. Pollen rain and pollen representation across a forest-páramo ecotone in northern Ecuador. Review of Palaeobotany and Palynology 157, 285-300.

MOSCOL OLIVEIRA, M. \& H. HOOGHIEMSTRA. 2010. Three millennia upper forest line changes in northern Ecuador: Pollen records and altitudinal vegetation distributions. Review of Palaeobotany and Palynology 163, 113-126.

NIEMANN, H. \& H. BEHLING. 2008. Late Quaternary vegetation, climate and fire dynamics inferred from the El Tiro record in the southeastern Ecuadorian Andes. Journal of Quaternary Science 23, 203-212.

NIEMANN, H. \& H. BEHLING. 2009. Late Pleistocene and Holocene environmental change inferred from the Cocha Caranga sediment and soil records in the southeastern Ecuadorian Andes. Palaeogeography, Palaeoclimatology, Palaeoecology 276, 1-14. 
NIEMANN, H. \& H. BEHLING. 2010. Late Holocene environmental change and human impact inferred from three soil monoliths and the Laguna Zurita multi-proxi record in the southeastern Ecuadorian Andes. Vegetation History and Archaeobotany 19, 1-15.

NIEMANN, H., T. HABERZETTL \& H. BEHLING. 2009. Holocene climate variability and vegetation dynamics inferred from the (11700 cal. yr BP) Laguna Rabadilla de Vaca sediment record, southeastern Ecuadorian Andes. The Holocene 19, 307-316.

NIEMANN, H., I. MATTHIAS, B. MICHALZIK \& H. BEHLING. 2013. Late Holocene human impact and environmental change inferred from a multi-proxy lake sediment record in the Loja region, southeastern Ecuador. Quaternary International, 308, 253-264.

PADUANO, G.M., M.B. BUSH, P.A. BAKER, P.A., FRITZ, S.C. \& G.O. SELTZER. 2003. A vegetation and fire history of Lake Titicaca since the Last Glacial Maximum. Palaeogeography, Palaeoclimatology, Palaeoecology 194: 259-279.

PODWOJEWSKI, P., J. POULENARD, T. ZAMBRANA \& R. HOFSTEDE. 2002. Overgrazing effects on vegetation cover and properties of volcanic ash soil in the páramo of Llangahua and La Esperanza (Tungurahua, Ecuador). Soil Use Managemant 18, 45-55.

RANGEL, O. 2006. Sintesis final: Visión integradora sobre la región del páramo. Diversidad Biotica III. La región de la vida paramuna. Universidad Nacional de Colombia. Pp: 816-838.

RODBELL, D.T. 1994. The timing of the last deglaciation in Cordillera Oriental, Northern Peru based on glacial geology and lake sedimentology. Geological Society of America Bulletin 105, 923-934.

RODRÍGUEZ, F. \& H. BEHLING. 2011. Late Holocene vegetation, fire, climate and upper forest line dynamics in the Podocarpus National Park, south-eastern Ecuador. Vegetation History and Archaeobotany 20, 1-14.

RODRÍGUEZ, F. \& H. BEHLING. 2012. Late Quaternary vegetation, climate and fire dynamics, and evidence of early to mid-Holocene Polylepis forests in the Jimbura region of the southernmost Ecuadorian Andes. Palaeogeography, Palaeoclimatology, Palaeoecology 350-352, 247-257.

SADORI, L. \& M. GIARDINI. 2007. Charcoal analysis, a method to study vegetation and climate of the Holocene: The case of Lago di Pergusa (Sicily, Italy). Geobios 40, 173-180.

SCHUBERT, C. \& C.M. CLAPPERTON. 1990. Quaternary glaciations in the Northern Andes (Venezuela, Colombia and Ecuador). Quaternary Science Reviews 9, 123-135.

STUIVER, M., P.J. REIMER \& R.W. REIMER. 2005. CALIB 6.0. Radiocarbon Calibration Program. URL: http://calib.qub.ac.uk/calib/calib.html

VALDEZ, F. 2008. Inter-zonal relationships in Ecuador. In: Silverman H, Isbell WH (eds) Handbook of South American archeology. Springer, New York, pp. 865-888.

VÉLEZ M.I., H. HOOGHIEMSTRA, S. METCALFE, M. WILLE \& J.C. BERRÍO. 2006. Late Glacial and Holocene environmental and climatic changes from a limnological transect through Colombia, northern South America. Palaeogeography, Palaeoclimatology, Palaeoecology 234, 81-96.

VILLOTA, A., S. LEÓN-YÁNEZ \& H. BEHLING. 2012. Vegetation and environmental dynamics in the Páramo of Jimbura region in the southeastern Ecuadorian Andes during the late Quaternary. Journal of South American Earth Sciences 40, 85-93.

WENG, C., M.A. BUSH, A.J. CHEPSTOW-LUSTY. 2004. Holocene changes of Andean alder (Alnus acuminata) in highland Ecuador and Peru. Journal of Quaternary Science 19, 685-691.

WENG, C., H. HOOGHIEMSTRA \& J.F., DUIVENVOORDEN. 2006. Challenges in estimating past plant diversity from fossil pollen data: statistical assessment, problems and possible solutions. Diversity and Distributions 12, 310-218. 
WHITLOCK, C. \& C. LARSEN. 2001. Charcoal as a fire proxy. In: Smol, J.P., Birks, H.J.B., Last, W.M., (eds) Tracking environmental change using lake sediments. Kluwer, Dordrecht, pp 75-98. 



\title{
CHAPTER 4
}

\section{Mid- and late Holocene vegetation and environmental dynamics in the Llanganates \\ National Park, Anteojos Valley, central Ecuadorian Andes}

\author{
Andrea Villota ${ }^{1,2}$ Susana León-Yánez ${ }^{1}$ \& Hermann Behling ${ }^{2}$ \\ ${ }^{1}$ Herbario QCA, Escuela de Ciencias Biológicas, Pontificia Universidad Católica del Ecuador, Quito- \\ Ecuador \\ ${ }^{2}$ Department of Palynology and Climate Dynamics, Albrecht---von---Haller Institute for Plant \\ Sciences, University of Göttingen, 37073 Göttingen, Germany
}

Palynology Journal, DOI: 10.1080/01916122.2014.977404. 


\begin{abstract}
The last ca. 4100 cal yr BP of palaeoenviromental conditions in the Llanganates National Park, central Ecuadorian Andes has been reconstructed from the pollen record "Anteojos Valley" (3984 $\mathrm{m}$ elevation). The pollen record, dated by 4 radiocarbon dates, indicates that the local páramo vegetation was relatively stable wit only some minor fluctuations since the mid-Holocene. The páramo vegetation was characterized mainly by Poaceae, Cyperaceae and Asteraceae. The regional Lower Mountain Rainforest vegetation is mainly represented by Moraceae/Urticaceae and the Upper Mountain Rainforest by, Melastomataceae, Polylepis and Weinmannia. Between ca. 4100 to $2100 \mathrm{cal}$ yr BP, páramo was the main vegetation type with low presence of mountain rainforest; probably reflecting cool conditions. Between ca. 2100 cal yr BP to the present, the proportion of páramo vegetation increased with a decreased occurrence of mountain rainforest suggesting cooler and moister conditions. Low frequencies of fires were evidenced since the midHolocene. However, there is a slight increase of regional fire between ca. 4100 to 3100 cal yr BP. The low abundance of larger carbonized particles since the beginning of the record, suggests low occurrence of local fire in the study area.

\section{Keywords}

Palaeoecology, Mid-Holocene, páramo, vegetation dynamic, central Ecuadorian Andes. 


\subsection{Introduction}

The tropical northern Andes region is well known by its very high floristic biodiversity and endemism due to its high structural and geological variety (Mutke \& Barthlott 2005). Especially, the Ecuadorian Andes harbour the most species rich ecosystems on earth (Barthlott et al. 2005), with almost ca. 2900 endemic species (León-Yánez et al. 2011). Different environmental conditions are responsible for this phenomenon, for example the uplift of mountain chains causing an extensive evolutionary radiation (Jorgensen \& Ulloa 1994) and the complex topography and highly varied climatic conditions (Richter 2008). The Ecuadorian Andes have a variety of ecosystems; the most characteristic one is páramo, due to its floristically unique and diverse ecosystem, which is found above the upper forest line.

Despite of the high level of biodiversity, the landscapes of the Ecuadorian Andes suffer a high degradation rate. Official sources report that, Ecuador currently suffered the highest deforestation rate of 3952000 ha year ${ }^{-1}$ between 1990 and 2010 (Mosandl et al. 2008; <http://www.mongabay.com>). Especially, páramo ecosystem is subject to overgrazing, burning and cultivation, which lead to reduction of biodiversity (Hofstede et al. 2002; Podwojewski et al. 2002). In general, human activity has a strong impact on the vegetation of the Ecuadorian Andes (Ramsay \& Oxley 1996), which have been inhabited for over 2000 years (e.g. Bellwood 2005). During the last 500 years or so in particular, the density of human populations has increased. In the last century an increasing amount of the open vegetation became increasingly converted into agricultural land (Dodson \& Gentry 1991, Pohle 2008).

Therefore, the knowledge of origin and past dynamics of páramo vegetation is important, as it is not well known. Palaeoecological studies can provide insight into vegetation changes, climate dynamics and anthropogenic impact. Only a limited number of palaeoecological studies are available from the Ecuadorian Andes. Several palaeoecological studies have been carried out in the southern Ecuadorian Andes at high elevations up to 3,300 m a.s.l., at the Podocarpus National Park (PNP) by the German-Ecuadorian Research Unit (www.tropicalmountainforest.org) (e.g. Niemann \& Behling 2008, 2010; Brunschön \& Behling 2009, 2010; Niemann et al. 2009, 2013; Brunschon et al. 2010; Rodriguez \& Behling 2011; Villota et al. 2012). Whereas there are only few studies located in the central and northern Ecuadorian Andes (e.g. Colinvaux et al. 1988; Hansen et al. 2003; Jantz \& Behling 2012; van der Hammen et al. 2003; Bakker et al. 2008). These studies 
demonstrate marked past vegetation and climate changes, as well as changing environments, e.g. by differing fire intensity and human impact regimes, and their influence on local and regional ecosystem dynamics. In general, there is a trend of a warm and dry mid-Holocene (8900-3300 cal $\mathrm{yr}$ BP) in the west and central Andes region of Ecuador. However, there are still uncertainties concerning the magnitude and time span of this mid-Holocene dry period. The late Holocene is in general characterized by wetter conditions.

In this paper, we present the results of a core from the Páramo of Lagunas de Anteojos area in the central Ecuadorian Andes. Our main objective is the reconstruction of the local and regional environmental history including vegetation, fire and climate dynamics to identify mechanisms of past ecosystem change and human impact. By addressing the following research questions: (1) How stable was the páramo vegetation of the Lagunas de Anteojos area since the mid-Holocene? (2) Played fire a role in the páramo vegetation? (3) Was there any human impact in the Lagunas de Anteojos area since the mid-Holocene?

\subsection{The Study region}

\subsubsection{Location}

The study area Lagunas de Anteojos is located in the páramo area of the Llanganates National Park (LNP), eastern slope of the eastern Cordillera (Cordillera Real) in the central Ecuadorian Andes (Figure 1). The Llanganates National Park, established in 1996, covers an area of 21900 ha and altitude ranges from 1200 to 4638 m a.s.l., between Cotopaxi, Tungurahua, Napo and Pastaza provinces.

The core analysed was recovered from a small peat bog, which is called "Anteojos valley" (ANT), located at the lake shore, about $10 \mathrm{~m}$ distance to the open water, The lake has a diameter of 500 $\mathrm{m}$ and is of glacial origin and is horseshoe shaped with deep and steep slopes. The core was taken at an elevation of $3984 \mathrm{~m}$ a.s.l. probably at the highest part of the eastern Cordillera (S $0^{\circ} 57.946^{\prime}$; W $\left.78^{\circ} 24.397^{\prime}\right)$. The location of the peat bog is ideal to record the local and regional environmental history of the study area. As peat bogs often have a strong local representation but also, due to its location, keeps the information given by the long distance air transported pollen from the wet montane forests. Also, peat bog may reflect the eruptive activity of volcanoes around the area such as Cotopaxi volcano the closest one (Figure 2). During the past 4500 years Cotopaxi's activity has left thin (up to $10 \mathrm{~cm}$ ) beds of scoria and pumice lapilli upon the flanks of the cone, and ash 
flows that traveled $10 \mathrm{~km}$ down the western, northern and southeastern flanks of the cone (Hall \& Mothes 2008).

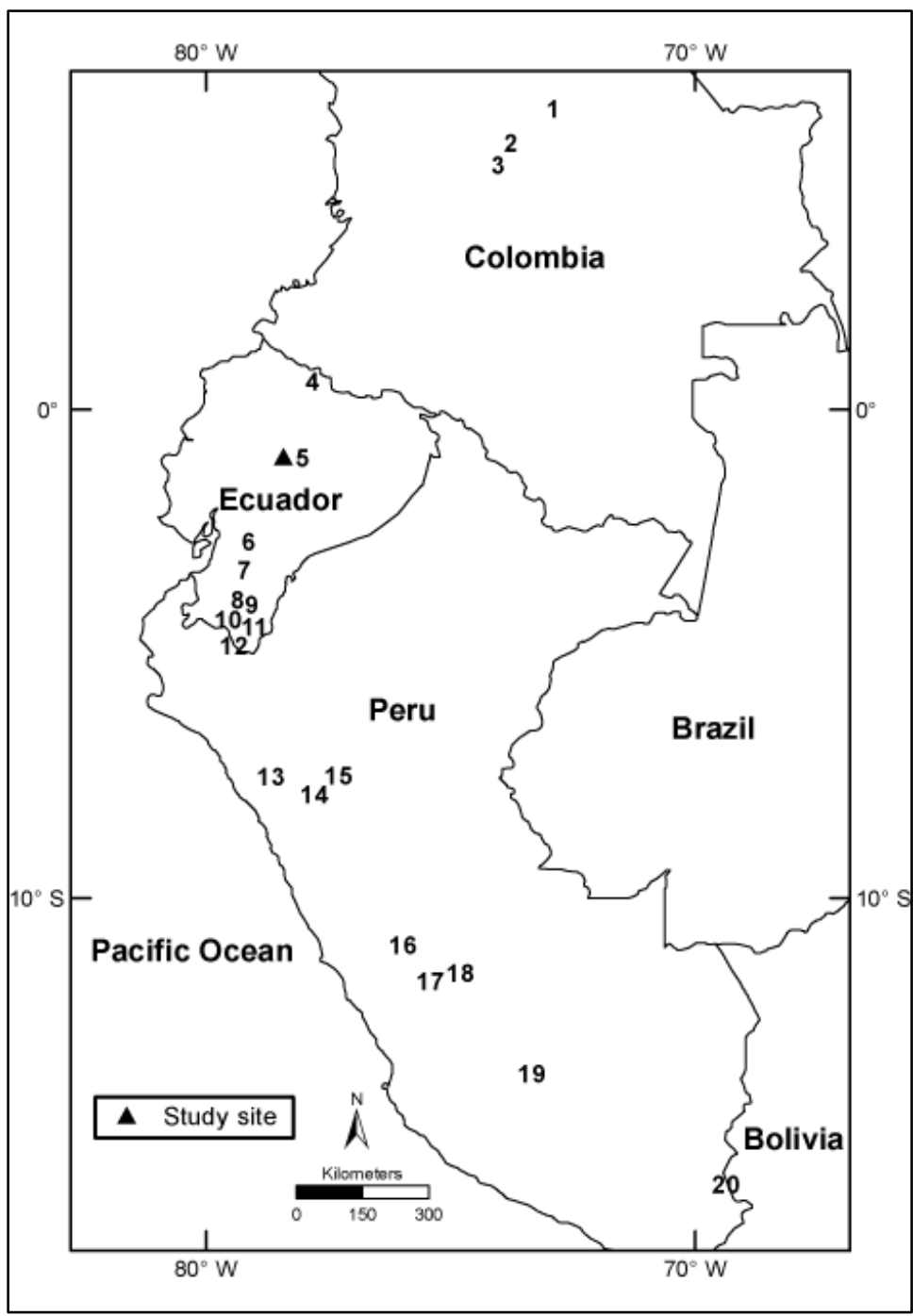

Figure 1. Map of northwestern South America, showing the location of the different study sites from the Ecuadorian Andes and neighboring countries and the study site of this paper Anteojos Valley (no. 5). 1. Cienega del Visitador; 2. Lake Fuquene; 3. Agua Blanca; 4. Guandera Biological Reserve; 6. Lagunas Chorreras; 7. Tres Lagunas; 8. Cocha Caranga; 9. Valle Pequeño; 10. Laguna Rabadilla de Vaca; 11. Cerro Toledo; 12. Lagunas Natosas; 13. Laguna La Compuerta; 14. Laguna Baja; 15. Laguna de Chochos; 16. Laguna Junín; 17. Lagunas Pomacocha; 18. Laguna Tuctua; 19. Laguna Pacucha; 20. Lake Titicaca. 


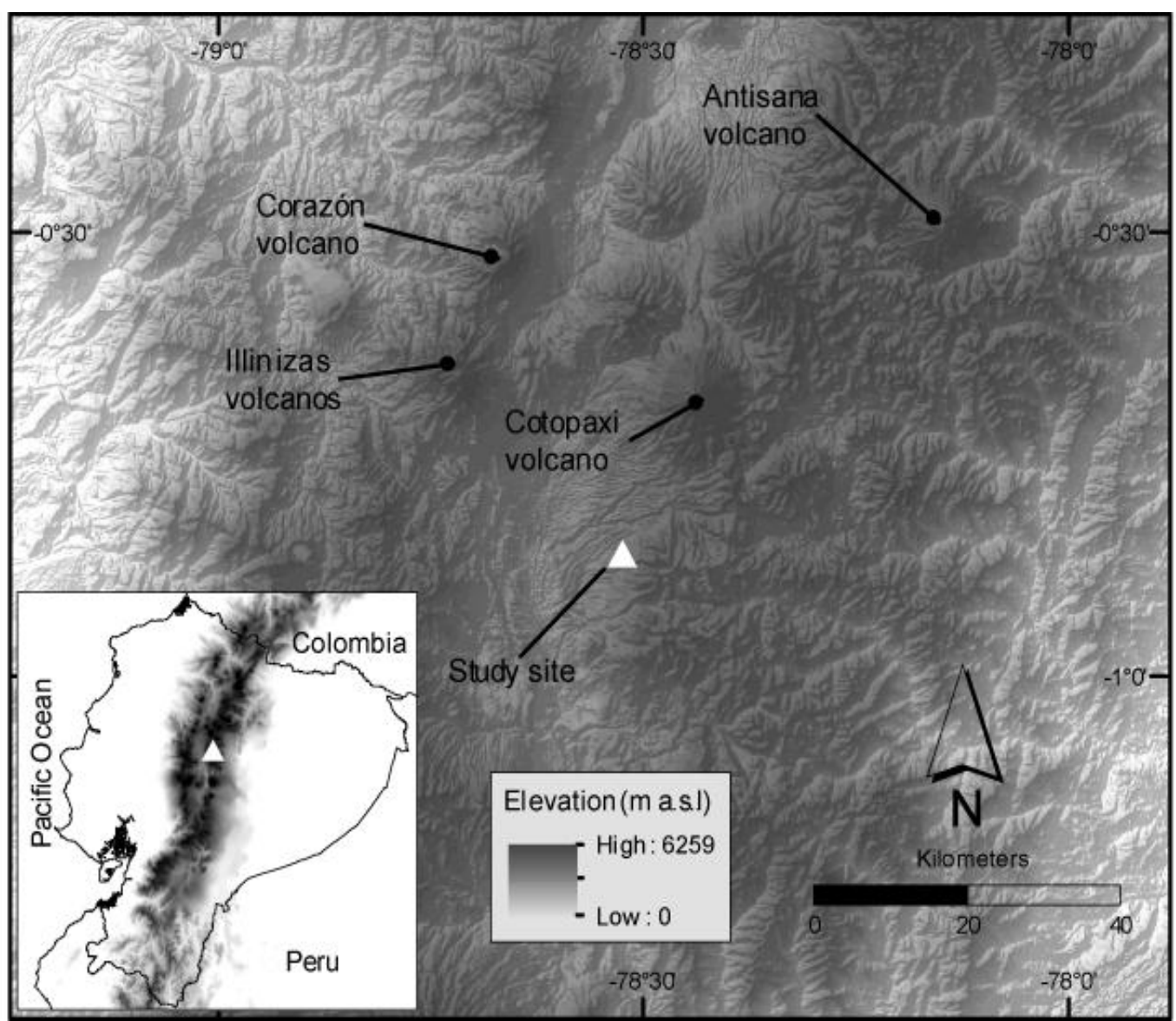

Figure 2. Map showing the study site of this paper, including the nearby volanoes

\subsubsection{Geology}

The eastern Andean Cordillera is mainly formed by Paleozoic metamorphic rocks (Baldock 1982). This is also found at the study area, as well as Llanganatis Group metamorphic rocks (quartz, gneiss and fine strips of marble) and volcanic rocks from the early Tertiary (Kennerley \& Bromley 1971). The volcanic activity in the region of Llanganates ended about 30 million years ago but continues to the present in nearby volcanoes like the Cotopaxi volcano. The eruptions deposited thick layers of ash in the region during the late Tertiary and Pleistocene. During the last glaciation the area was covered by glaciers (Kennerley \& Bromley 1971).

\subsubsection{Climate}

The climate of Ecuador including the study area is dominated by the tropical trade wind regime, characterised by strong easterlies bringing moist air masses from the Amazon basin (Beck et al. 
2008). The Cordillera Real acts as a climatic divide separating moist conditions on the eastern side from the (semi-) desert climate on the west (Emck 2007). In the Anteojos valley area, the mean annual rainfall is about $1300 \mathrm{~mm}$. The main rainy season lasts from January to April, with a drier period between June to September. The coldest period of the year is generally the main rainy season. The mean annual temperature varied between $3^{\circ}$ and $13^{\circ} \mathrm{C}$ (INAMHI 2012).

\subsubsection{Vegetation}

According to Vargas et al. (2000) the vegetation of the study area is classified in three different vegetation types: lower and upper mountain rainforest and páramo. The studied site is surrounded mainly by páramo vegetation (including shrub and herb páramo).

The lower mountain rainforest (LMF) occurs between ca. 1300-2000 m a.s.l. with canopy heights between 25-30 m. Characteristic genera are Clusia spp., Clethra spp., Acalypha spp., Hyeronima spp., Morus spp., Trema spp., Piper spp., Urera spp. The upper mountain rainforest (UMF) is found between 2900-3600 m a.s.I. with canopy heights up to $25 \mathrm{~m}$. Some of the main key taxa are Escallonia, Miconia, Myrsine, Hesperomeles, Cedrela, Weinmannia, Alnus. The páramo occurs above the upper forest line between $3600-5000 \mathrm{~m}$ a.s.I. Páramo vegetation is characterized by plants with a maximum height of $2 \mathrm{~m}$. Some key taxa are Arcytophyllum, Blechnum, Calamagrostis, Chusquea, Gynoxis, Halenia, Huperzia, Monnina, Neurolepis, Niphogeton, Oxalis, Puya, Rhynchospora and Valeriana.

The present vegetation around the LNP is partially degraded due to deforestation and land conversion into pastures and cultivations (Vargas et al. 2000). Currently, disturbance is primarily restricted to the surrounding areas and some border zones.

The local vegetation of the peat bog is provided by León-Yánez (personal communication 2010) based on 6 plots, 3 of them located in the valley area and 3 on the slope area. The páramo vegetation is characterized mainly by herbs and grasses: Azorella aretioides, Eryngium humile, Niphogeton dissecta, Baccharis caespitosa, Erigeron ecuadoriensis, Hypochaeris sessiliflora, Loricaria thuyoides, Werneria nubigena, Valeriana spp., Carex pichinchensis, Oreobolus obtusangulus, Uncinia macrolepis, Disterigma empetrifolium, Vaccinium floribundum, Gentiana sedifolia, Geranium spp., Gunnera magellanica, Hypericum lancioides, Sisyrinchium jamesonii, Plantago rigida, Agrostis foliata, Calamagrostis spp, Cortaderia sericantha, and Lachemilla spp. 


\subsubsection{Human settlement}

There is a long and diverse history of human impact in the region of the northern Andes. The earliest record of human occupation in the region of the central Ecuadorian Andes close to Laguna de Anteojos is Inga (9000 uncal yr BP), where traces of manufactured artefacts have been found (Bell 1971). The Inga site is located at $2520 \mathrm{~m}$ a.s.l, ca. $100 \mathrm{~km}$ north from the study site (Pichincha province).

The present-day Panzaleo settlers colonized the limits of the Llanganates National Park; especially, the páramo area. The main activities carried out are agricultural and livestock. Therefore, human influence does not affect directly the landscape of the national park (Chiriboga et al. 2000).

\subsection{Material and Methods}

\subsubsection{Sediment extraction}

The "Anteojos valley" (ANT) sediment core was taken with a Russian Corer. The total length of the recovered core is $400 \mathrm{~cm}$. Sections of $50 \mathrm{~cm}$ length were placed in splitted PVC tubes covered with plastic film and stored under dark and cold $\left(+4{ }^{\circ} \mathrm{C}\right)$ conditions at Pontificia Universidad Católica del Ecuador in Quito before processing.

For accelerator mass spectrometer (AMS) radiocarbon dating, 4 subsamples containing organic material were submitted to the University of Erlangen-Nürnberg (Germany). The ${ }^{14} \mathrm{C}$ dates were calibrated using the curve SHCal04. ${ }^{14} \mathrm{C} \mathrm{SH}$ terrestrial dataset of the Calib 6.0 software (Stuiver et al. 2005)

\subsubsection{Palynological analysis}

For palynological analysis, the ANT core was sampled at $4 \mathrm{~cm}$ intervals along the core, resulting in 89 subsamples of $0.5 \mathrm{~cm}^{3}$ each. All subsamples were processed using the standard pollen analytical methods (Fægri \& Iversen 1989). One tablet of exotic Lycopodium clavatum spores, containing $20848 \pm 1546$ spores (batch code 1031), was added to each sample before treatment as a marker for calculation of pollen and charcoal concentration and influx. A minimum of 300 pollen grains was counted for each sample. The pollen sum includes pollen of herbs, shrubs, trees and indeterminate taxa and excludes fern spores and pollen of aquatic taxa. The spores of 
Pteridophyta, Isoëtes and Sphagnum were counted and quantified as percentages based on the pollen sum.

The identification of pollen and spores was based on the reference published by Hooghiemstra (1984), electronic pollen keys of Ecuador (3000 neotropical taxa and ca. 620 Ecuadorian taxa), kept at the department of Palynology and Climate Dynamics, and the Neotropical Pollen Database (Bush \& Weng 2007). In order to differentiate between pollen grains of Zea mays from the other Poaceae grains the size was taken into account. Pollen size of Zea mays varies between 100 and $120 \mu \mathrm{m}$ and the other Poaceae taxa between 25 and $40 \mu \mathrm{m}$. Identified taxa were classified into ecological groups that correspond to the prevailing vegetation types: Lower Mountain Rainforest (LMF), Upper Mountain Rainforest (UMF), Páramo and Pteridophyta. The pollen types that could not be identified were grouped in the indeterminate taxa. For charcoal analysis the technique developed by Finsinger et al. (2008) was used, relating charcoal particles to the concentration of Lycopodium clavatum spores (marker). Charcoal particles were counted up to a total count of 100 Lycopodium clavatum spores. The counted charcoal particles were separated in two groups of different particle sizes $(10-100 \mu \mathrm{m}$ and $>100 \mu \mathrm{m})$ to be able to give more detailed information about the fire history (Sadori \& Giardini 2007). Fragments between 10 and $100 \mu \mathrm{m}$ indicate regional fires, and fragments $>100 \mu \mathrm{m}$ local fire (Whitlock \& Larsen 2001). 


\subsubsection{Data analysis}

The software TILIA was used for data calculation of percentages, sums, as well as pollen and charcoal concentration and influx. TILIAGRAPH software was used to illustrate the data, as well as stratigraphy and the calibrated (cal) and uncalibrated (uncal) dates (Grimm 1987). The program CONISS was used to conduct a cluster analysis of the pollen data which were included in the pollen sum to generate a dendrogram (Grimm 1987), helping to identify the pollen zones.

\subsection{Results}

\subsubsection{Stratigraphy}

The $400 \mathrm{~cm}$ long peat bog sediment core from Anteojos Valley (ANT) consists of little to highly decomposed organic material, silt, clay and volcanic ash. From 400 to $160 \mathrm{~cm}$ the sediment is more compact and contains decomposed organic material, clay and silt. Above, $160 \mathrm{~cm}$ the sediment is less compact with volcanic ash and less decomposed organic material with roots and plant remains. A detailed description of the stratigraphic units is given in Table 1.

Table 1. Stratigraphic description of the sediment core Anteojos Valley (ANT).

\begin{tabular}{ll}
\hline Depth (cm) & Description \\
\hline $0-50$ & Very little decomposed organic material; with plant remains (roots); dark \\
& brown colored \\
$50-120$ & Little decomposed organic material with small roots; light brown \\
$120-140$ & Volcanic ash \\
$140-185$ & Less decomposed organic material with roots; brown \\
$185-190$ & Clayey material, light greyish \\
$190-255$ & Little decomposed organic material with small roots; brown \\
$255-260$ & Clayey material mixed with organic material; dark greyish \\
$260-275$ & Silt material, light-brown colored \\
$275-285$ & Clayey/silt material; dark greyish \\
$285-310$ & Little decomposed organic material with small roots; brown \\
$310-320$ & Clayey material; dark greyish \\
$320-340$ & Decomposed organic material, dark brown \\
$340-350$ & Clayey material; light greyish \\
$350-355$ & Highly decomposed organic material; dark brown \\
$355-400$ & Little decomposed organic material with roots; brown colored \\
\hline
\end{tabular}




\subsubsection{Chronology and pollen zonation}

The chronology of the core Anteojos valley (ANT) is based on four AMS radiocarbon dates (Table 2) performed at the AMS laboratory at the University of Erlangen/Nürnberg, Germany. Extrapolation of the dates suggests that the base of the core has an age of ca. $4100 \mathrm{cal}$ yr BP that probably reflects the beginning of sediment accumulation.

The series of four AMS dates shows a consistent age-depth model (Figure 3) (Blaauw 2010; version 2.2), which indicates that sediments accumulated since the mid-Holocene. The average sediment accumulation rate is $1.17 \mathrm{~mm} \mathrm{yr}^{-1}$. In detail it is $0.70 \mathrm{~mm} \mathrm{yr}^{-1}$ (4100 to $1200 \mathrm{cal} \mathrm{yr} \mathrm{BP}$ ),

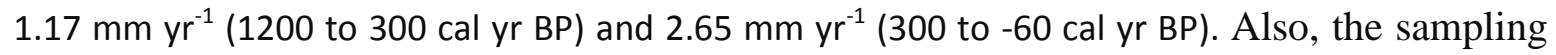
resolution varies between 15 and 57 years per sample. The CONISS cluster analysis and major changes in the pollen assemblages suggest two main pollen zones ANT-I with two subzones (ANTIa and ANT-Ib) and ANT-II with three subzones (ANT-Ila, ANT-IIb and ANT-IIc).

Table 3. List of AMS radiocarbon dates and calibrated ages from the Anteojos Valley (ANT) core using the curve SHCal04. ${ }^{14} \mathrm{C} \mathrm{SH}$ terrestrial dataset of the Calib 6.0 software.

\begin{tabular}{|c|c|c|c|c|}
\hline Lab. Code & Depth $(\mathrm{cm})$ & Dated Material & ${ }^{14} \mathrm{C}$ age (yr BP) & $1-\sigma(\mathrm{cal}$ yr BP) \\
\hline Erl-16076 & $99-100$ & Organic material & $265 \pm 48$ & $184 \pm 34$ \\
\hline Erl-16077 & $199-200$ & Organic material & $1296 \pm 57$ & $1171 \pm 117$ \\
\hline Erl-16078 & $299-300$ & Organic material & $2598 \pm 58$ & $2606 \pm 154$ \\
\hline Erl-16079 & $399-400$ & Organic material & $3782 \pm 95$ & $4100 \pm 258$ \\
\hline
\end{tabular}




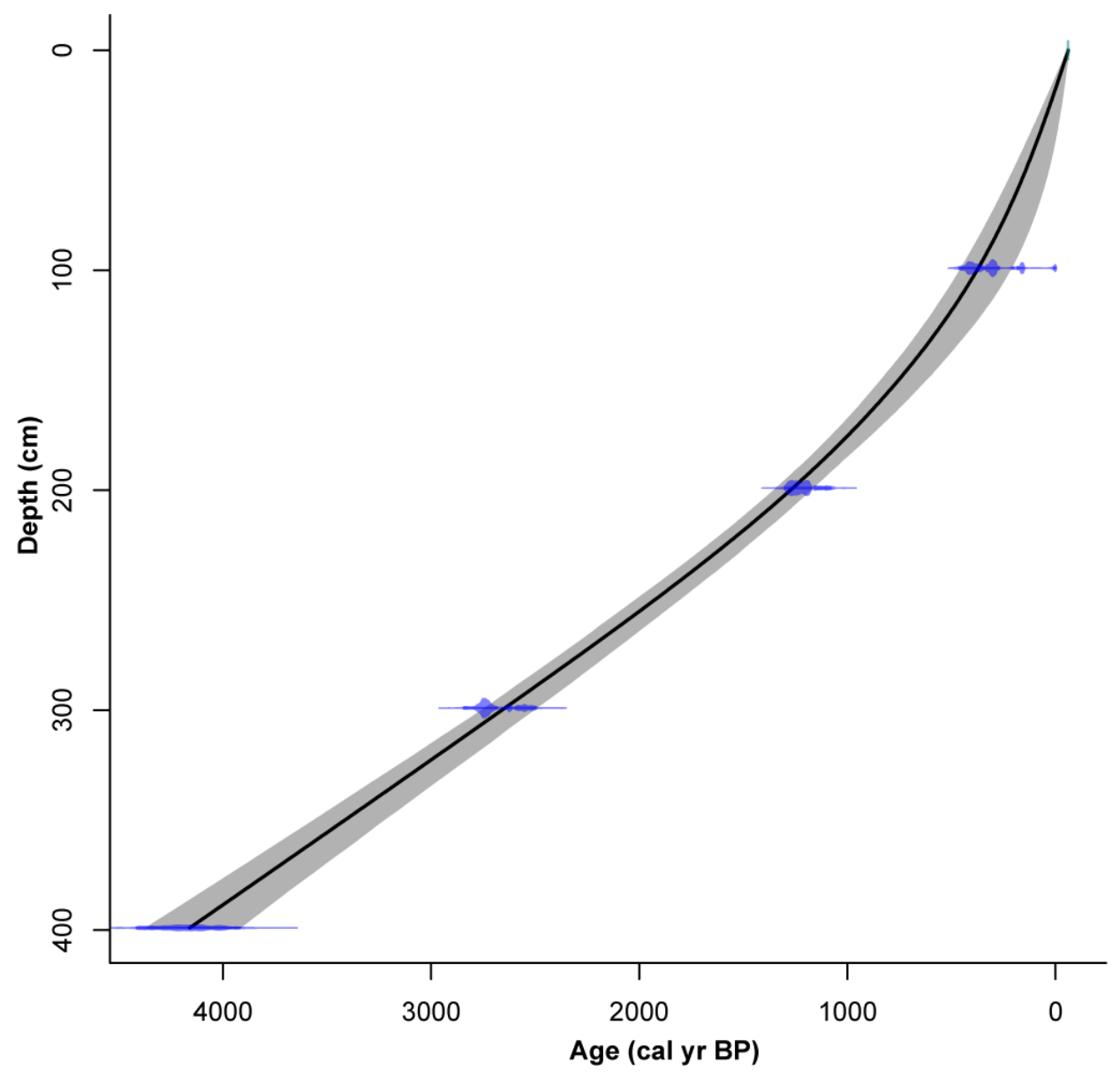

Figure 3. Age-depth model for the Anteojos Valley (ANT) core based on the four calibrated radiocarbon dates.

\subsubsection{Description of the pollen diagram}

A detailed pollen percentage diagram displays 20 different pollen taxa with a representation of $>2 \%$ out of 66 pollen types and 5 spores types with a representation of $>2 \%$ out of 14 identified taxa (Figure 4). The summary percentage diagram (Figure 5) shows the pollen and spores grouped into the vegetation types: Lower Mountain Rainforest (LMF), Upper Mountain Rainforest (UMF), Páramo and Pteridophyta (without Isoëtes) and concentration and influx of pollen and charcoal particles.

Pollen concentration and influx vary between $10,000-85,000$ grains $/ \mathrm{cm}^{3}$ and between $950-10,000$ grains $/ \mathrm{cm}^{2} / \mathrm{yr}$, respectively. The charcoal concentration of the two counted fraction vary between $600,000-55,700,000$ particles $/ \mathrm{cm}^{3}$ (small fraction) and 85,000-950,000 particles $/ \mathrm{cm}^{3}$ (large fraction). The charcoal influx for both counted fractions varies between 170,000-3,500,000 
particles $/ \mathrm{cm}^{2} / \mathrm{yr}$ (small fractions) and between 6000-66,000 particles $/ \mathrm{cm}^{2} / \mathrm{yr}$ (large fraction) (Figure 5).

Subzone ANT-la (400-334 cm; ca. 4100-3100 cal yr BP, 16 samples), is characterized by stable proportion of LMF pollen taxa (30\%), mainly due to high values of Moraceae/Urticaceae (25\%). UMF pollen taxa show stable values (10\%), such as Melastomataceae (1-2\%), Polylepis/Acaena pollen (2\%) represents the highest values of the record. Myrsine and Weinmannia pollen occur with low values (from 1 to 3\%). This subzone is marked by relatively high values of Páramo taxa (60-80\%), especially by pollen of Poaceae (40-50 \%) and Cyperaceae (15-20\%), which present the highest values of the subzone. Valeriana and Plantago australis pollen shows increased values, $(5 \%)$ and (10\%) respectively, at the upper part of the subzone. In this subzone Pteridophyta spores show the lowest values of the record (10\%) mainly by Huperzia (10\%). Isöetes spores (17\%) are very frequent and show the highest values in this subzone (Figure 4).

Subzone ANT-Ib (334-262 cm; ca. 3100-2100 cal yr BP, 17 samples), is marked by a slightly higher representation of LMF pollen (from 30 to 35\%), e.g. Moraceae/Urticaceae (30\%), Trema type and Celtis (2-3\%), which present the highest values in this subzone. UMF pollen taxa show stable representation (10\%) with Melastomataceae (1-2\%) and Myrsine, Weinmannia and Macrocarpaea (from 1 to $2 \%$ ). Páramo pollen taxa slightly decreased to 70\%, mainly by Poaceae (35-40\%). Pollen of Cyperaceae show stable values (20\%). At the top of this subzone Asteraceae pollen (10\%) increased slightly. Also, Plantago rigida pollen has higher values (5\%) in this subzone. Compared to the previous subzone, Pteridophyta show stable proportions (10\%), mainly due to Huperzia (10\%); this is also seen in spores of Lycopodium jussiaei and Osmunda (1\%). In this subzone spores of Isoëtes are absent (Figure 4).

Subzone ANT-Ila (262-150 cm; ca. 2100-760 cal yr BP, 27 samples), is characterized by a slightly lower representation of LMF pollen (20\%), due to the lower proportion of Moraceae/Urticaceae (20\%). However, pollen of Trema type and Celtis show stable values (2\%). Proportion of UMF pollen taxa increased slightly $(20 \%)$ at the middle of this subzone, mainly due to high percentages of Melastomataceae (5\%). Stable proportion of Myrsine and Weinmannia (2\%) is shown. Also, compared to the previous subzones Hedyosmum pollen presents the highest values of the record (3\%). Values of Páramo pollen taxa increased slightly (75\%), such as, Asteraceae (15-20\%) at the bottom of this subzone. Also, Gentianaceae (6\%) pollen slightly increased. In this subzone 
Pteridophyta spores (20-30\%) increased mainly by the high presence of Huperzia spores (15-25\%) and Cyatheaceae (1-2\%) (Figure 4).

Subzone ANT-IIb (150-60 cm; ca. 760-180 cal yr BP, 21 samples), shows a stable proportion of LMF pollen (20\%), by Moraceae/Urticaceae (20\%), Trema type and Celtis (2\%). The proportion of UMF pollen taxa decreased slightly (8\%) by Myrsine and Hedyosmum (1-2 \%). Melastomataceae show stable values (4\%). Weinmannia pollen is represented by higher values $(3 \%)$ in this subzone. Compared to the previous subzone, Páramo taxa show stable percentage (75\%), especially by Asteraceae (15\%). Also Poaceae pollen presents stable values (35\%). Pollen of Gentianaceae (10\%) and Gunnera (3\%) increased slightly. Cyperaceae pollen (10-15\%) shows the lowest values of the record in this subzone. Pteridophyta remain stable between 25 and 35\%. Proportion of Lycopodium jussiaei spores (20\%) increased in this subzone (Figure 4).

Subzone ANT-Ilc (60-0 cm; ca. 180 to -60 cal yr BP, 8 samples), is characterized by a stable representation of LMF pollen taxa. Acalypha pollen presents the highest values (2\%) of the record in this subzone. UMF pollen taxa slightly decreased at the top of the subzone. Symplocos pollen represents the highest values (1-3\%) of the record in this subzone. Páramo pollen taxa represent stable proportion, such as Cyperaceae (10\%), Asteraceae (15\%) and Gentianaceae (10\%). Poaceae (20\%) pollen decreased. Pollen of Plantago australis (3\%) and Gunnera (2-5\%) increased. Zea mays pollen represents the highest value (2-3\%) of the record in this subzone. In this subzone Pteridophyta spores (20-30\%) are mainly represented by Lycopodium jussiaei (20\%), which presents the highest values of the record (Figure 4). 


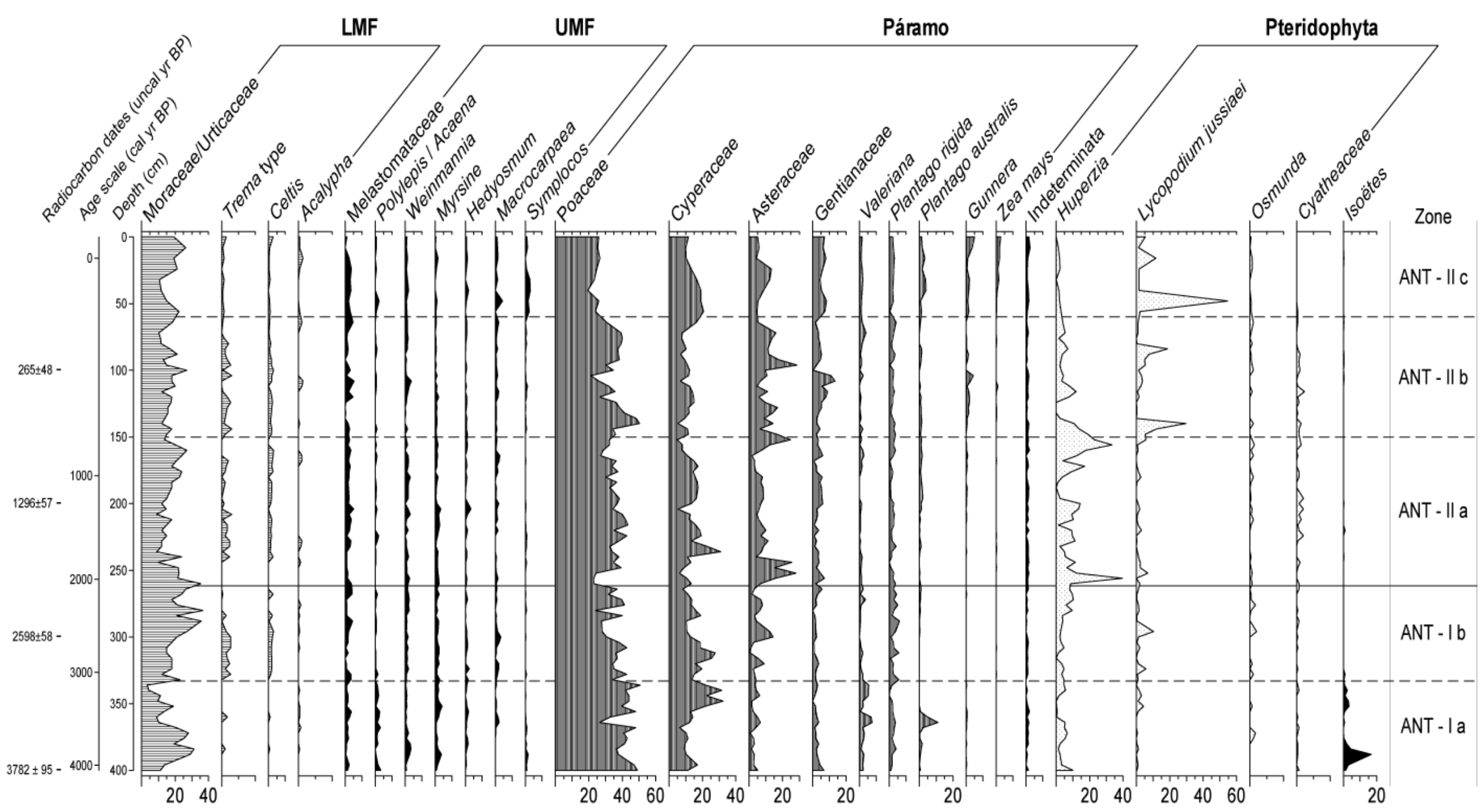

Figure 3. Pollen percentage diagram of the Anteojos Valley peat bog core (ANT, $3984 \mathrm{~m}$ elevation) showing selected fossil pollen and spore taxa grouped into Lower Mountain Rainforest (LMF), Upper Mountain Rainforest (UMF), Páramo and Pteridophyta. 


\subsection{Interpretation and discussion of the environmental record}

The pollen record from the Anteojos valley (ANT) at $3984 \mathrm{~m}$ elevation reflects the local and regional development and vegetation dynamics in the Llanganates National Park (LNP) on eastern slope of the eastern Cordillera. Due to the small peat bog area as well as the location of the studied area, the more local aspect of the development and dynamic of the Lower Mountain Rainforest (LMF), Upper Mountain Rainforest (UMF) and Páramo of the Páramo of Laguna de Anteojos is revealed. Pollen and spores data suggest that the vegetation was relatively stable with some fluctuations. Páramo vegetation, which today naturally covers the area, exists around the coring site from the beginning of the record since the mid-Holocene from ca. $4100 \mathrm{cal}$ yr BP.

\subsubsection{Mid-Holocene}

The mid-Holocene period, from about 4100 to 3100 cal yr BP (zone ANT-la), indicates that grass páramo was the main vegetation type around the study area; while mountain rainforest was somewhat lower represented; probably reflecting cool conditions relative to those of today.

Pollen of the LMF taxa were represented mainly by Moraceae/Urticaceae, probably located at lower elevations. Based on modern pollen rain studies, Moraceae/Urticaceae can be transported easily by wind and dispersed over large distances from lower to higher elevations. The longdistance transport of pollen in the Andes has already been observed (e.g. Weng et al. 2004; Reese \& Kam-Biu 2005; Niemann et al. 2010; Ortuño et al. 2011; Jantz et al. 2013). Main components of the UMF were Polylepis, Weinmannia and Myrsine suggesting small populations in form of forest patches in the study area. Polylepis presents the highest occurrence in the record during this period. Studies by Hansen et al. (2003) indicate that during the mid-Holocene Polylepis reached its maximum, probably favored by a dry season. Also, a study by Urrego et al. (2011) suggests that Polylepis woodlands grew close to the lakes and were probably favored by these environmental conditions. Slightly higher proportion of páramo occurred during this period, mainly by high abundance of Poaceae, Cyperaceae and Valeriana reflecting cooler conditions relative to those of today. Also, there are local frequent occurrences of cushions mires of Plantago rigida and Plantago australis at high elevation in grass páramo. The high abundance of grass páramo vegetation and the presence of Polylepis provide a robust overall image of relatively cool conditions during this period. Furthermore, the grass páramo is associated with high presence of Huperzia and Isoëtes. Especially, Isoëtes mostly occurs submerged in páramo lakes and is a good 
proxy for the existence of a shallow lake (Bosman et al. 1994; Gosling et al. 2008). In addition, high presence of grass páramo and highest occurrence of Isoëtes during this period and clay material shown in the stratigraphy also suggests a decrease of the lake level; as the peat bog is near to the lake shore.

During the mid-Holocene, high charcoal influx for both counted fractions indicates that fires occurred in the study area. Especially, there is a slight increase in the small particles influx which suggests regional fire. It is important to mention, human populations expanded rapidly and are engaged in landscape modification in the Andes during the mid-Holocene (e.g. Binford et al. 1997; Brenner et al. 2001; Niemann \& Behling 2008). The first increased presence of human in this region was after 9000 yr BP, according to the Inga archaeological record (Bell 1971).

\subsubsection{Mid- to late Holocene}

The mid- to late Holocene (ca. 3100-2100 cal yr BP, zone ANT-Ib), is marked by gradual change, indicated by a slightly decreased proportion of páramo vegetation followed by a slight expansion of mountain forest; especially the LMF.

During this period, the LMF vegetation increases slightly mainly by the relatively strong proportion of Moraceae/Urticaceae and slight abundance of Trema and Celtis. Stable proportion of UMF was shown in the pollen record; but there is evidence of a slight increase of Macrocarpaea and decrease of Polylepis. The slight increase of LMF and the stable proportion of UMF suggest a better establishment of mountain rainforest vegetation in the study area during this period. Relatively low proportion of páramo was reached mainly by low abundance of Poaceae, Cyperaceae, Valeriana and $P$. australis. Though, Asteraceae and $P$. rigida slightly increase during this period; suggesting a cooler and moister period (Marchant et al. 2002, Hansen et al. 2003; Bakker et al. 2008). Stable proportion of Pteridophyta occurred in this period. However, abundance of Lycopodium jussiaei slightly increased during this period as well as, Osmunda which often reflects disturbed areas (Brunschön \& Behling 2009). In addition, Isoëtes became rare at the study site; probably suggesting an increase of the lake level. Compared to the mid-Holocene, in this period relatively low values of charcoal influx suggests low frequency of fires in the study area.

\subsubsection{Late Holocene}


The late Holocene period, from about 2100 cal yr BP to the present (zone ANT-Ila-c), shows stable presence of mountain rainforest taxa with small fluctuations between LMF and UMF. Especially, the UMF slightly increase during this period. Whereas, proportion of páramo increase slightly and maintain this proportion during the whole period. Also, fluctuations with partly high frequency of Pteridophyta occurred.

The LMF decreased, in particular Moraceae/Urticaceae. However, Acalypha became slightly more frequent in the forest during this period. Whereas the LMF decreased, the UMF presence increased slightly. A particular high abundance by Melastomataceae, Myrsine and Hedyosmum (between 2100 - $760 \mathrm{cal} \mathrm{yr} \mathrm{BP)} \mathrm{and} \mathrm{later} \mathrm{by} \mathrm{Macrocarpaea} \mathrm{and} \mathrm{Symplocos} \mathrm{(between} 180 \mathrm{cal}$ yr BP to the present) may reflect a slow and continuous increase of temperature. During this period páramo vegetation expanded slightly and was dominated mainly by Cyperaceae with increasing proportions of Asteraceae; suggesting less lacustrine conditions. Also, slightly higher abundance of Gentianaceae, P. rigida, Gunnera occurred. Zea mays is evident between 760 to the present. Zea mays is a good indicator of human impact, and is considered as one of the most important crops. Pteridophytes occurred more frequently with some fluctuations. Huperzia and Lycopodium characterize the upper cold wet páramo (Hansen et al. 2003). The dominance of Huperzia along with high distribution of other Lycopodiaceae, suggests wetter and cooler conditions (Hansen et al. 2003).

Low charcoal influx of both carbonized particles indicates rare fire and suggests the absence of human activity in the study area. Especially there is evidence of low frequency of larger charcoal fragments after $180 \mathrm{cal}$ yr BP, suggesting that local fires were absent

\subsection{Comparison of the results with other records}

The Anteojos valley record, located at 3984 m elevation, will be compared to close by studied sites in the Colombian, Ecuadorian and Peruvian Andes.

In general, the mid-Holocene is characterized by drier conditions, in the west and central Andes region of Ecuador, Peru and Bolivia (Hansen et al. 2003; Paduano et al. 2033; Weng et al. 2006). However, other past environmental change studies describe this period as one of increased drought frequency punctuated with episodic wet events, rather than as a single dry 'event' (Paduano et al. 2003, Bush et al. 2005, Valencia et al. 2010). Especially, the period around 4000 to 
3800 yr BP is characterized by environmental changes; where pollen records point to increasing climatic humidity (e.g. lake Titicaca) (Cross et al. 2000; Marchant et al. 2001). A wet mid-Holocene is recorded in Anteojos valley between ca. 4100 to 2100 cal yr BP. Comparable results at the northern Ecuadorian Andes are obtained from the Guandera Biological Reserve which indicates that the basin became more humid, during ca. 5320 to $2160 \mathrm{cal}$ yr BP by the presence of plants of wet bog conditions. Also, records from the southern Ecuadorian Andes shows cooler and moister conditions during this period. Like, the pollen record of Laguna Chorreras shows a decrease of Podocarpaceae pollen with high Sphagnum abundance, followed by cooler and wetter conditions. Also pollen records of the Podocarpus National Park (southern Ecuador) shows similar vegetation pattern as the study site. The pollen record of Laguna Rabadilla de Vaca shows that Poaceae dominated herb-páramo, from ca. 3680 cal yr BP to present, reflecting cooler climatic conditions (Niemann et al. 2009). The Cerro Toledo record shows a gradual change in the vegetation composition after 4700 cal yr BP. Grass páramo vegetation, dominated by Poaceae with increasing proportions of Cyperaceae, expanded substantially under cooler conditions (Brunschön \& Behling 2009).

Like the pollen records from the Ecuadorian Andes, pollen records from Colombia show a similar vegetation pattern to the study area; where a period of increased moisture centered after approximately 3500 uncal yr BP (Marchant et al. 2001). For example the Llano Grande II record shows a cool and wet environment after 3000 uncal yr BP (Velásquez 2005).

During the late Holocene, after ca. 2100 cal yr BP, the vegetation composition at the study area Anteojos valley is similar to what has been found in the pollen records through the Ecuadorian Andes. Pollen record from the Guandera Biological Reserve indicate an increase of páramo vegetation and a decrease in temperature between 2000 and 800 cal yr BP (Bakker et al. 2008). In the Pantano de Pecho record, Poaceae dominated the páramo vegetation from ca. 3700 uncal yr BP until present; reflecting cooler climatic conditions (Wille et al. 2002). Unlike Antejos valley, the Cerro Toledo record shows after ca. 1800 cal yr BP a slight decrease in páramo and increase in subpáramo and mountain forest taxa, suggesting warmer temperatures (Brunschön \& Behling 2009).

\subsection{Conclusions}


- The Anteojos valley sediment core at $3984 \mathrm{~m}$ a.s.l. presents a palaeoenviromental record since the mid-Holocene, on the eastern slope of the eastern Cordillera (Llanganates National Park) in the central Ecuadorian Andes.

- Since the mid-Holocene starting at ca. $4100 \mathrm{cal}$ yr BP, presence of páramo vegetation was stable in the study area, dominated by Poaceae, Cyperaceae and Asteraceae. The Lower and Upper Mountain Rainforest remained relatively stable during the recorded period except a few variations.

- Especially between ca. 4100 to 2100 cal yr BP, páramo was the main vegetation type but with a lower presence of mountain rainforest; probably reflecting cool conditions. After, ca. 2100 cal yr BP proportion of páramo increase slightly and maintained this proportion until present times; whereas stable presence of mountain rainforest was evident, suggesting cooler and wetter conditions.

- Low frequencies of fires are recorded since the beginning of the record at the study site. Regional fires were slightly more frequent between ca. 4100 to 3100 cal yr BP.

- Even though, the study area was surrounded by human settlements; located at lower elevations, it was not strongly affected by anthropogenic activities as shown by a relatively stable vegetation and low occurrence of carbonized particles.

\subsection{Acknowledgements}

We thank the Deutsche Forschungsgemeinschaft (DFG) for financial support (BE 2116/8-2) within the research unit FOR 816 "Biodiversity and sustainable management of a megadiverse mountain ecosystem in southern Ecuador". Nele Jantz and Andrés Gerique are thanked for their assistance with the fieldwork. Felix Matt, Jörg Zeilinger and the Team at the ECSF research station are thanked for logistical support.

\subsection{References}

Bakker J, Moscol M, Hooghiemstra H. 2008. Holocene environmental change at the upper forest line in northern Ecuador. The Holocene 18: 877-893. 
Baldock JW. 1982. Geology of Ecuador - explanatory bulletin of the national geological map of the Republic of Ecuador, scale 1:1,000,000. Ministerio de Recursos Naturales y Energéticos, Dirección General de Geología y Minas, Quito.

Barthlott W, Mutke J, Rafiqpoor D, Kier G, Kreft H. 2005. Global centers of vascular plant diversity. Nova Acta Leopold 92:61-83

Beck E, Bendix J, Kottke I, Makeschin F, Mosandl R (eds.). 2008. Gradients in a tropical mountain ecosystem of Ecuador. Ecological Studies 198. Springer, Berlin, Heidelberg.

Bell R. 1971. Investigation of the Inga Complex and Preceramic Occupations of Highland Ecuador. Final report to the National Science Foundation.

Bellwood P. 2005. First farmers. The origins of agricultural societies. Blackwell Malden. Mass, USA. $360 \mathrm{pp}$.

Binford MW, Kolata AL, Brenner M, Janusek JW, Seddon MT, Abbott M, Curtis JH. 1997. Climate variation and the rise and fall of an Andean civilization. Quaternary Research 47: 235-248.

Blaauw M. 2010. Clam. Version 2.2. URL: http://chrono.qub.ac.uk/blaauw/clam.html\#refs

Bosman A, Hooghiemstra H, Cleef A. 1994. Holocene mire development and climatic change from a high Andean Plantago rigida cushion mire. The Holocene 43: 233-243.

Brenner M, Hodell, DA, Curtis JH, Rosenmeier MF, Binford MW, Abbott MB. 2001. Abrupt climate change and Pre-Columbian cultural collapse. In Interhemispheric Climate Linkages, Markgraf V (ed.). Academic Press: San Diego, CA; 87-104.

Brunschön C, Behling H. 2009. Late Quaternary vegetation, fire and climate history reconstructed from two cores at Cerro Toledo, Podocarpus National Park, southeastern Ecuadorian Andes. Quaternary Research 72: 388-399.

Brunschön C, Behling H. 2010. Reconstruction and visualization of upper forest line and vegetation changes in the Andean depression region of southeastern Ecuador since the last glacial maximum - A multi-site synthesis. Review of Palaeobotany and Palynology 163: 139-152.

Brunschön C, Haberzettl T, Behling H. 2010. Highresolution studies on vegetation succession, hydrological variations, anthropogenic impact and genesis of a subrecent lake in southern Ecuador. Vegetation History and Archaeobotany 19: 191-206.

Bush MB, Weng C. 2007. Introducing a new (freeware) tool for palynology. Journal of Biogeography 34: 377-380.

Bush MB, Hansen BCS, Rodbell DT, Seltzer GO, Young KR, Leon B, Abbott MB, Silman MR, Gosling WD. 2005. A 17 000-year history of Andean climate and vegetation change from Laguna de Chochos, Peru. Journal of Quaternary Science 20: 703-714.

Butler R. 1994-2006. Ecuador Forest Information and Data. URL: http://www.mongabay.com/

Chiriboga C, Carvajal J, Endara N. 2000. Diagnóstico socioeconómico de cuatro poblaciones aledañas al Parque Nacional Llanganates. En: Vázquez, M.A. y M. Larrea (Eds.). Biodiversidad en el Parque Nacional Llanganates: un reporte de las evaluaciones ecológicas y socioeconómicas rápidas. EcoCiencia, Ministerio del Ambiente, Herbario Nacional del Ecuador, Museo Ecuatoriano de Ciencias Naturales e Instituto Internacional de Reconstrucción Rural. Quito.

Colinvaux PA, Olson K, Liu KB. 1988. Late-glacial and Holocene pollen diagrams from two endorheic lakes of the Inter-Andean plateau of Ecuador. Review of Palaeobotany and Palynology 55: 83-99.

Cross SL, Baker PA, Seltzer GO, Fritz SC, Dunbar RB. 2000. A new estimate of the Holocene lowstand level of Lake Titicaca, central Andes, and implications for tropical palaeohydrology. The Holocene 10: 21-32.

Dodson C, Gentry AH. 1991. Biological extinction in western Ecuador. Annals of the Missouri Botanical Garden 78: 273-295. 
Emck P. 2007. A Climatology of South Ecuador - With Special Focus on the Major Andean Ridge as Atlantic- Pacific climate Divide. Dissertation, Universität Erlangen, Nürnberg.

Fægri K, Iversen J. 1989. Textbook of Pollen Analysis, 4th ed. Wiley, Chichester.

Finsinger W, Tinner W, Hu F. 2008. Rapid and accurate estimates of microcharcoal content in pollen slides. Pp. 121-124 in Charcoals from the past: cultural and palaeoenvironmental implications. Proceedings of the Third International Meeting of Anthracology, CavallinoLecce (Italy), June 28th-July 1st 2004. Archaeopress, Oxford, UK; available from Hadrian Press.

Gosling WD, Bush MB, Hanselman JA, Chepstow-Lusty A. 2008. Glacial-Interglacial changes in moisture balance and the impact on vegetation in the southern hemisphere tropical Andes (Bolivia/Peru). Palaeogeography, Palaeoclimatology, Palaeoecology, 259(1): 35-50.

Grimm EC. 1987. CONISS: a Fortran 77 program for stratigraphically constrained cluster analysis by the method of the incremental sum of squares. Computer and Geosciences 13: 13-35.

Hall M, Mothes P. 2008. Volcanic impediments in the progressive development of pre-Columbian civilizations in the Ecuadorian Andes. Journal of Volcanology and Geothermal Research 176: 344-355.

Hansen BCS, Rodbell DT, Seltzer GO, León B, Young KR, Abbott M. 2003. Late-glacial and Holocene vegetation history from two sides in the western Cordillera of southwestern Ecuador. Palaeogeography, Palaeoclimatology, Palaeoecology 194: 79- 108.

Hofstede R, Groenendijk J, Coppus R, Fehse J, Sevink J. 2002. Impact of Pine Plantations on Soils and Vegetation in the Ecuadorian High Andes. Mountain Research and Development 22:159-167.

Hooghiemstra H. 1984. Vegetation and Climatic History of the High Plain of Bogota, Colombia: a continuous record of the last 3.5 million years. Dissertationes Botanicae 79. Cramer, Vaduz.

Instituto Nacional de Meteorología e Hidrología-INAMHI. 2012. Anuario Meteorológico 2010. Volumen $\mathrm{N}^{\circ}$ 50. Quito-Ecuador.

Jantz N, Behling H. 2012. A Holocene environmental record reflecting vegetation, climate, and fire variabil- ity at the Páramo of Quimsacocha, southwestern Ecua- dorian Andes. Vegetation History and Archaeobotany 21: 169-185.

Jantz N, Homeier J, León-Yánez S, Moscoso A, Behling H. 2013. Trapping pollen in the tropics Comparing modern pollen rain spectra of different pollen traps and surface samples across Andean vegetation zones. Review of Palaeobotany and Palynology 193: 57-69.

Jørgensen PM, Ulloa C. 1994. Seed Plants of the High Andes of Ecuador-check List. AAU Reports, 34, pp. 1-443.

Kennerley J, Bromley B. 1971. Geology and geomorphology of the Llanganatis mountains, Ecuador. Minerva-Quito

Laboratory for Climatology and Remote Sensing. 2007-2014. Platform for biodiversity and ecosystem monitoring and research in South Ecuador. URL: http://www.tropicalmountainforest.org/

León-Yánez S, Valencia R, Pitman N, Endara L, Ulloa C, Navarrete H (eds.). 2011. Libro rojo de las plantas endémicas del Ecuador, 2a. ed., Publicaciones del Herbario QCA. Pontificia Universidad Católica del Ecuador. Quito, Ecuador

Marchant R, Behling H, Berrio JC, Cleef JD, Hoohiemstra H, Kuhry P, Melief B, Van Geel B, Van der Hamenn T, Van Reenen G, Wille M.2001. Mid- to Late-Holocene pollen-based biome reconstructions for Colombia. Quaternary Science Reviews 20: 1289-1308.

Marchant R, Almeida L, Behling H, Berrio JC, Bush M, Cleef A, Duivenvoorden J, Kappelle M, De Oliveira P, de Oliveira-Filho AT, Lozano-García S, Hooghiemstra H, Ledru MP, Ludlow- 
Wiechers B, Markgraf V, Mancini V, Paez M, Prieto A, Rangel O, Salgado-Labouriau ML. 2002. Distribution and ecology of parent taxa of pollen lodged within the Latin American Pollen Database. Review of Palaeobotany and Palynology 121: 1-75.

Mosandl R, Günter S, Stimm B, Weber M. 2008. Ecuador suffers the Highest Deforestation Rate in South America. In: Beck, E., Bendix, J., Kottke, I., Makeschin, F., Mosandl, R. (Eds.), Gradients in a Tropical Mountain Ecosystem of Ecuador. Ecological Studies vol. 198, Springer, Berlin, Heidelberg, pp. 37-40.

Mutke J, Barthlott W. 2005. Patterns of vascular plant diversity at continental to global scales. Biologiske Skrifter 55: 521-531.

Niemann H, Behling H. 2008. Late Quaternary vegetation, climate and fire dynamics inferred from the El Tiro record in the southeastern Ecuadorian Andes. Journal of Quaternary Science 23: 203-212.

Niemann H, Behling H. 2010. Late Holocene environ- mental change and human impact inferred from three soil monoliths and the Laguna Zurita multi-proxi record in the southeastern Ecuadorian Andes. Vegetation History and Archaeobotany 19: 1-15.

Niemann H, Haberzettl T, Behling H. 2009. Holocene climate variability and vegetation dynamics inferred from the $(11,700$ cal yr BP) Laguna Rabadilla de Vaca sediment record in the southeastern Ecuadorian Andes. The Holocene 19: 307-316.

Niemann H, Brunschön C, Behling H. 2010. Vegetation/ modern pollen rain relationship along an altitudinal transect between 1920 and 3185 m a.s.I. in the Podocarpus National Park region, southeastern Ecuadorian Andes. Review of Palaeobotany and Palynology 159: 6980.

Niemann H, Matthias I, Michalzik B, Behling H. 2013. Late Holocene human impact and environmental change inferred from a multi-proxy lake sediment record in the Loja region, southeastern Ecuador. Quaternary International. http://dx.doi.org/10.1016/j.quaint. 2013.05.22

Ortuño T, Ledru MP, Cheddadi R, Kuentz A, Favier C, Beck S. 2011. Modern pollen rain, vegetation and climate in Bolivian ecoregions. Review of Palaeobotany and Palynology 165, 61-74.

Paduano GM, Bush MB, Baker PA, Fritz SC, Seltzer GO. 2003. A vegetation and fire history of Lake Titicaca since the Last Glacial Maximum. Palaeogeography, Palaeoclimatology, Palaeoecology 194: 259- 279.

Podwojewski P, Poulenard J, Zambrana T, Hofstede R. 2002. Overgrazing effects on vegetation cover and properties of volcanic ash soil in the páramo of Llangahua and La Esperanza (Tungurahua, Ecuador). Soil Use Management 18: 45-55.

Pohle P. 2008. The people settled around Podocarpus National Park. In: Beck E, Bendix J, Kottke I, Makeschin F, Mosandl R (eds) Gradients in a tropical mountain ecosystem of Ecuador. Ecol Stud 198. Springer Verlag, Berlin, Heidelberg, pp 25-36

Ramsay PM, Oxley E. 1996. Fire temperatures and postfire plant community dynamics in Ecuadorian grass Páramo. Vegetation 124: 129-144.

Reese C, Kam-Biu L. 2005. A modern pollen rain study from the central Andes region of South America Journal of Biogeography 32:709-718.

Richter M. 2008. Tropical mountain forests-distribution and general features. In: Gradstein SR, Homeier J, Gansert D (eds) The Tropical Mountain Forest Patterns and Processes in a Biodiversity Hotspot. Biodivers Ecol Ser, vol 2, Universitätsverlag Göttingen, pp 7-24

Rodríguez F, Behling H. 2011. Late Holocene vegetation, fire, climate and upper forest line dynamics in the Podocarpus National Park, southeastern Ecuador. Vegetation History and Archaeobotany 20: 1-14. 
Sadori L, Giardini M. 2007. Charcoal analysis, a method to study vegetation and climate of the Holo- cene: The case of Lago di Pergusa (Sicily, Italy). Geobios 40: 173-180.

Stuiver M, Reimer PJ, Reimer RW. 2005. CALIB 6.0. Radiocarbon Calibration Program. URL: http://calib.qub.ac.uk/calib/calib.html

Urrego DH, Niccum BA, La Drew CF, Silman MR, Bush MB. 2011. Fire and drought as drivers of early Holocene tree line changes in the Peruvian Andes. Journal of Quaternary Science 26: 28-36.

Valencia BG, Urrego DH, Silman MR, Bush MB. 2010. From ice age to modern: a record of landscape change in an Andean cloud forest. Journal of Biogeography 37: 1637-1647.

Van der Hammen T, Noldus G, Salazar E. 2003. Un diagrama de polen del Pleistoceno final y Holoceno de Mullumica. Maguaré 17, 247-259.

Vargas H, Neill D, Asanza M, Freire-Fierro A, Narváez E. 2000. Vegetación y flora del Parque Nacional Llanganates. En: Vázquez, M.A. y M. Larrea (Eds.). Biodiversidad en el Parque Nacional Llanganates: un reporte de las evaluaciones ecológicas y socioeconómicas rápidas. EcoCiencia, Herbario Nacional del Ecuador, Museo Ecuatoriano de Ciencias Naturales e Instituto Internacional de Reconstrucción Rural. Quito.

Velásquez CA. 2005. Paleoecología de alta resolución del Holoceno tardío en el Páramo de Frontino. PhD Thesis, Universidad Nacional de Colombia, Bogota. Also published in Hooghiemstra, H., editor, The Quaternary of Colombia 30, 199 pp.

Villota A, León-Yánez S, Behling H. 2012. Vegetation and environmental dynamics in the Páramo of Jimbura region in the southeastern Ecuadorian Andes during the late Quaternary. Journal of South American Earth Sciences 40: 85-93.

Weng C, Bush MB, Chepstow-Lusty AJ. 2004. Holocene changes of Andean alder (Alnus acuminata) in highland Ecuador and Peru. Journal of Quaternary Science 19: 685-691.

Weng C, Bush MB, Curtis JH, Kolata AL, Dillehay TD, Binford MW. 2006. Deglaciation and Holocene climate change in the western Peruvian Andes. Quaternary Research 66, 87-96.

Whitlock C, Larsen C. 2001. Charcoal as a fire proxy. Pp. 75-98 in Smol J.P., Birks H.J.B. \& W.M Last (eds.). Tracking environmental change using lake sediments. Kluwer, Dordrecht.

Wille M, Hooghiemstra H, Hofstede R, Fehse J, Sevink J. 2002. Upper forest line reconstruction in a deforested area in northern Ecuador based on pollen and vegetation analysis. Journal of Tropical Ecology 18: 409-440. 



\section{CHAPTER 5}

\section{Synthesis}

The knowledge of late Quaternary palaeoecological conditions, especially in the central and southern Ecuadorian Andes, is still limited - despite the importance to understand vegetation changes, climate dynamics and anthropogenic impact. The palaeoecological studies presented in the previous chapters of this dissertation contribute to an increase in knowledge of the late Quaternary. In the following chapter, main research goals of this dissertation are discussed and synthesized.

\subsection{Discussion}

\subsubsection{Late Pleistocene vegetation and climate dynamics at key sites in the Central and South Ecuadorian Andes}

Late Quaternary environmental changes were investigated in chapters 2 to 4 by the means of pollen, spore and charcoal analysis. The total of three multi-proxy data sets from different study sites helped to elucidate important questions and offer a comprehensive overview of vegetation and climate dynamics from the central and southern Ecuadorian Andes for the late Pleistocene and Holocene.

During the Last Glacial Maximum (LGM) (ca. 21,000 - 15,000 cal yr BP), most of the Ecuadorian Andes were covered by glaciers, which moved down slope and reached their lowermost positions at about $3000 \mathrm{~m}$ (Rodbell 1994). Nevertheless, the palaeoenviromental record of El Cristal (Chapter 2), which is located at 2056 m elevation, reveals that between ca. 19,700-12,500 cal yr BP, glaciers did not cover the study site, allowing the mountain forest to develop and cover the area. Thus, mountain forest was the main vegetation type. In particular, there is evidence of occurrence of Polylepis forests at low elevations in the northern part of the Andean Depression, which does not occur today. However, there is also evidence of relatively high proportions of 
páramo taxa which suggest that an open mountain rainforest occupied the region during this period. The presence of páramo taxa during the late Pleistocene indicates that the upper forest line (UFL) was at a markedly lower elevation. At the end of the LGM, the retreat of glaciers formed U-shapes valleys often spotted with small water bodies leaving bedrocks exposed. During the late Glacial period (ca. 15,000 - 11,500 cal yr BP), the process of deglaciation continued. Forest taxa became more frequent and shifted upslope, favored by a moister and somewhat warmer climate (Bølling-Allerød interstadial from ca. 15,000 to 14,000 cal yr BP) (Rodbell and Seltzer 2000); thus repressing páramo vegetation. However, the advance of forest vegetation was limited because of a short colder period (Younger Dryas, from ca. 12,900 to 11,600 cal yr BP) (Rodbell and Seltzer 2000) prior to the persistent warming into the Holocene. Despite that in Ecuador there is no clear signal of the Bølling-Allerød interstadial and the Younger Dryas, the Cajanuma valley sediment record (Chapter 3), located at $3284 \mathrm{~m}$ a.s.l., reveals that during the late Glacial after ca. 16,000 cal. yr BP an herb páramo rich in Poaceae, Cyperaceae and Gentianaceae, associated with a high presence of Huperzia and Isoëtes, was the main vegetation type reflecting cool and wet conditions. During the late Glacial, the UFL occurred at a much lower elevation than today.

The transition to the Holocene led to a gradual change towards warmer climatic conditions with temperatures peaking in early Holocene times. This is evident in the El Cristal record which, between the transition from the late Pleistocene to the early Holocene, ca. from 11,500 to 7800 cal yr BP, was characterized by small fluctuations between the forest taxa coupled with stable proportions of subpáramo and páramo taxa reflecting colder and warmer conditions. During the early Holocene the upper mountain rainforest (UMF) was stronger represented (Myrica and Polylepis) and the lower mountain rainforest (LMF) had stable proportions. During the early to mid-Holocene warmer conditions also favored the development of forest vegetation. In particular, the mid-Holocene period between ca. 7800 - 3600 cal yr BP, is characterized by slightly decreased of UMF (Hedyosmum, Myrica and Polylepsis) while the proportion of LMF showed a small increased (Alchornea). After ca. $4000 \mathrm{cal}$ yr BP, the Polylepis forest decreased probably because of an increase in the frequency of fire during this dry period, as it is a fire-sensitive tree. Also, a substantial decline of Isoëtes indicates that the shallow water pond was probably replaced by a swamp. As well as El Cristal record, the Cajanuma valley record presented a gradual change towards warmer climatic conditions. During the early to mid-Holocene (ca. 10,500 - $5600 \mathrm{cal}$ yr BP), high abundance of páramo vegetation (Plantago rigida) was followed by a slight expansion of mountain forest (Symplocos taxa) into higher elevations. The partial replacement of treeless 
páramo suggests relatively warm and somewhat drier conditions. The UFL shifted upslope to higher elevations where it is today.

The mid-Holocene is characterized by drier conditions in the Andes of Ecuador (Hansen et al. 2003; Jantz and Behling 2012; Niemann and Behling 2009). Especially during the mid-Holocene, there was an increase in the spread of shrubs into the páramo vegetation. This is evident at El Cristal record, from ca. 3600 - 1380 cal yr BP, by a high occurrence of mountain forest taxa and landscape disturbance taxa. However, new past environmental change studies describe this period as one of increased drought frequency punctuated with episodic wet events, rather than as a single dry 'event' (Paduano et al. 2003, Van der Hammen et al. 2003, Bush et al. 2005, Bakker et al. 2008, Niemann et al. 2009, Valencia et al. 2010). The Cajanuma record shows that after ca. 5600 cal yr BP páramo vegetation re-expanded with the dominance of Poaceae, thus suggesting a change to cooler conditions. In addition, the high presence of Huperzia and Cyatheaceae suggests wetter conditions; pointing out that the mid-Holocene is not a single dry 'event'. Moreover, the Anteojos valley record (Chapter 4), located at $3984 \mathrm{~m}$ a.s.I., reveals that during the mid-Holocene (ca. 4100 - 3100 cal yr BP), grass páramo, mainly dominated by Poaceae, Cyperaceae and Asteraceae, was the main vegetation type. Mountain forest was lower represented, suggesting small populations in form of forest patches around the study site. Especially the presence of Polylepis, which has the highest occurrence during this period, indicates relatively dry conditions. Hence, high abundance of grass páramo, Polylepis and Isoëtes provide a robust overall image of relatively cool and dry conditions during this period.

Since the late Holocene until present-day there is a continuous fluctuation between páramo and forest taxa; and climate changes towards more humid and slightly cooler conditions at many sites in the Andes of Ecuador (Niemann and Behling 2008, 2009). The El Cristal record, from ca. 1380 cal $\mathrm{yr}$ BP to the present, is an example of an expansion of páramo taxa and a low proportion of mountain forest. Hence the vegetation changed to an open grassy landscape with forest patches. As well as the El Cristal record, Cajanuma valley shows that during the late Holocene period since 1200 cal yr BP, continuous cool and wetter conditions are suggested; páramo was the main vegetation type that covered the study area. On the other hand, the Anteojos valley record shows that during the late Holocene (since ca. 2100 cal yr BP) grass páramo expanded mainly dominated by Cyperaceae. In addition, Huperzia and Lycopodium, which characterize the upper cold wet páramo, became more frequent. 


\subsubsection{Fire and Human Impact in the Central and South Ecuadorian Andes landscapes}

Past fires influenced local vegetation composition as well as páramo and forest expansion, it is one of the woodland abundance controls in the Andes (Kessler 1995, Bush et al. 2008). However, fires are rarely responsible for extensive forest destruction. There are two types of fires: natural and from anthropogenic origin. Natural fires are suggested to be present when drier conditions and woody vegetation covered the area. On the other hand, fires from anthropogenic origin are mostly suggested to be present when wetter conditions exist. Especially once the mid-Holocene drought ends, human populations expanded rapidly and engaged in landscape modification (Brenner et al. 2001, Niemann and Behling 2008). Hence, more frequent fires were recorded from early to late Holocene times (Niemann and Behling 2008, 2009, Brunschön and Behling 2009, Rodríguez and Behling 2011). Besides the lightening of fires, humans continuously affect local vegetation development and biodiversity. In general, human activity has a strong impact on the vegetation of the Ecuadorian Andes - through slash and burn cultivation, pasture and deforestation (Ramsay and Oxley 1996). Especially during pre-Columbian times, human impact became stronger at most of the sites (Dodson and Gentry 1991, Wunder 2000, Pohle 2008). Some evidence of the human impact is indicated by the presence of key pollen grains: Zea mays and Amaranthaceae/Chenopodiaceae can be seen as indicators for local agriculture (Hansen et al. 2003, Niemann and Behling 2010, Valencia et al. 2010). Alnus, Ambrosia, Dodonaea and Muehlenbeckia/Rumex indicate disturbance and forest clearings (Hansen et al. 2003, Brunschön and Behling 2009, Valencia et al. 2010).

During the late Pleistocene low charcoal influx indicates that fire was rare (Chapter 2 and 3). Fires became slightly frequent during the mid- to late Holocene (Chapter 2 and 3). Regional fires were slightly more frequent since ca. $4100 \mathrm{cal} \mathrm{yr} \mathrm{BP}$ (Chapter 4). Since the late Holocene fires became more common, reflecting fires of anthropogenic origin (chapter 2 - 4). Presence of human impact was evident mainly by the presence of the pollen grains of Zea mays between 760 to the present (Chapter 4). Even though the study sites were surrounded by human settlements (Chapter 3 and 4), they were not strongly affected by anthropogenic activities as is shown by a relatively stable vegetation and low occurrence of carbonized particles.

\subsection{Concluding remarks and perspectives}


The high complexity and heterogeneity of the landscapes of the Ecuadorian Andes, as well as sitespecific interactions of multiple factors determining vegetation patterns, are responsible for the observed differences at the studied locations. The detailed results provided in this dissertation give a good overview of different temporal and spatial patterns in pollen data of the Central and Southern Ecuadorian Andes since the late Pleistocene. This study supports the idea that observed changes in distribution and composition of the vegetation in response to past climatic changes improve the basis for an elaborated view on some possible ecosystem dynamics in the light of future global change and conservation issues; as the results presented show that ecosystems in the studied area generally cope well with even ecosystem changes.

In general, the present vegetation structure of the study area was developed under both climatic dynamics and human impact. Upslope shifts of the mountain forest vegetation, as a result of rising temperatures, were recorded since the LGM. Also, fires and climate dynamics caused changes in the distribution and composition of páramo and forest vegetation. Despite the continuous human impact vegetation patterns are poorly affected.

In order to improve the present regional reconstruction and visualization of palaeoenvironments in the Ecuadorian Andes, future investigations should be carried out in the Central and Northern Ecuadorian Andes, as many of the palaeoecological studies are concentrated in the Andean Depression, especially in the Podocarpus National Park. Those studies should certainly focus on the amplification of modern pollen rain data and palaeoenvironmental records. This would improve the basis for data interpretation, especially in terms of the estimation on altitudinal ranges of upper forest line shifts and the change in diversity throughout time.

\subsection{Reference}

Bakker, J., M. Moscol Olivera, and H. Hooghiemstra. 2008. Holocene environmental change at the upper forest line in northern Ecuador. The Holocene 18: 1-17.

Brenner M., D.A. Hodell, J.H., Curtis, M.F. Rosenmeier, M.W. Binford and M.B. Abbott. 2001. Abrupt climate change and Pre-Columbian cultural collapse. In Interhemispheric Climate Linkages, Markgraf V (ed.). Academic Press: San Diego, CA pp. 87-104.

Brunschön, C. and H. Behling. 2009. Late Quaternary vegetation, fire and climate history reconstructed from two cores at Cerro Toledo, Podocarpus National Park, southeastern Ecuadorian Andes. Quaternary Research 72: 388-399.

Bush, M.B., B.C.S. Hansen, D.T. Rodbell, G.O. Seltzer, K.R. Young, B. Leon, M.B. Abbott, M.R. Silman, and W.D. Gosling. 2005. A 17 000-year history of Andean climate and vegetation change from Laguna de Chochos, Peru. Journal of Quaternary Science 20: 703-714. 
Bush, M.B., M.R. Silman, C. McMichael, and S. Saatchi. 2008. Fire, climate change and biodiversity in Amazonia: A Late-Holocene perspective. Philosophical Transactions of the Royal Society B: 363: 1795-1802.

Dodson C, and A.H. Gentry. 1991. Biological extinction in western Ecuador. Annals of the Missouri Botanical Garden 78: 273-295.

Hansen, B.C.S., D.T. Rodbell, G.O. Seltzer, B. León, K.R. Young, and M. Abbott. 2003. Late-glacial and Holocene vegetation history from two sides in the western Cordillera of southwestern Ecuador. Palaeogeography, Palaeoclimatology, Palaeoecology 194: 79-108.

Jantz, N. and H. Behling. 2012. A Holocene environmental record reflecting vegetation, climate, and fire variability at the Páramo of Quimsacocha, southwestern Ecuadorian Andes. Vegetation History and Archaeobotany 21: 169-185.

Kessler, M. 1995. Polylepis-Wälder Boliviens: Taxa, Ökologie, Verbreitung und Geschichte. Dissertationes Botanicae 246. J. Cramer, Berlin.

Niemann, H., and H. Behling. 2008. Late Quaternary vegetation, climate and fire dynamics inferred from the El Tiro record in the southeastern Ecuadorian Andes. Journal of Quaternary Science 23:203-212.

Niemann, H., and H. Behling. 2009. Late Pleistocene and Holocene environmental change inferred from the Cocha Caranga sediment and soil records in the southeastern Ecuadorian Andes. Palaeogeography, Palaeoclimatology, Palaeoecology 276: 1-14.

Niemann H., T. Haberzettl, and H. Behling. 2009. Holocene climate variability and vegetation dynamics inferred from the $(11,700 \mathrm{cal}$ yr BP) Laguna Rabadilla de Vaca sediment record in the southeastern Ecuadorian Andes. The Holocene 19: 307-316.

Niemann, H., and H. Behling. 2010. Late Holocene environmental change and human impact inferred from three soil monoliths and the Laguna Zurita multi-proxi record in the southeastern Ecuadorian Andes. Vegetation History and Archaeobotany 19:1-15.

Paduano, G.M., M.B. Bush, P.A. Baker, S.C. Fritz, and G.O. Seltzer. 2003. A vegetation and fire history of Lake Titicaca since the Last Glacial Maximum. Palaeogeography, Palaeoclimatology, Palaeoecology 194: 259-279.

Pohle P. 2008. The people settled around Podocarpus National Park. In: Beck E, Bendix J, Kottke I, Makeschin F, Mosandl R (eds) Gradients in a tropical mountain ecosystem of Ecuador. Ecol Stud 198. Springer Verlag, Berlin, Heidelberg, pp 25-36

Ramsay P.M., and E. Oxley. 1996. Fire temperatures and postfire plant community dynamics in Ecuadorian grass Páramo. Vegetation 124: 129-144.

Rodbell, D.T. 1994. The timing of the last deglaciation in Cordillera Oriental, Northern Peru based on glacial geology and lake sedimentology. Geological Society of America Bulletin 105: 923-934.

Rodbell, D.T., and G.O. Seltzer. 2000. Rapid ice margin fluctuations during the Younger Dryas in the tropical Andes. Quaternary Research 54: 328-338.

Rodríguez, F. and H. Behling, H. 2011. Late Holocene vegetation, fire, climate and upper forest line dynamics in the Podocarpus National Park, southeastern Ecuador. Vegetation History and Archaeobotany 20: 1-14.

Valencia, B.G., D.H. Urrego, M.R. Silman, and M.B. Bush. 2010. From ice age to modern: a record of landscape change in an Andean cloud forest. Journal of Biogeography 37: 1637-1647.

Van der Hammen T., G. Noldus, and E. Salazar. 2003. Un diagrama de polen del Pleistoceno final y Holoceno de Mullumica. Maguaré 17: 247-259.

Wunder, S. 2000. The economics of deforestation: the example of Ecuador. St. Martin, New York. 


\section{Appendix}

\section{Appendix A}

1.1 List of identified pollen and spores taxa grouped into the four major vegetation types with a short description. 
List of identified pollen taxa grouped into the four major vegetation types

\begin{tabular}{|c|c|c|c|c|c|}
\hline $\begin{array}{l}\text { Photo } \\
\text { No. }\end{array}$ & Family & Pollen & Vegetation type & Morphology & Record \\
\hline 1 & Adoxaceae & Viburnum & LMF & $\begin{array}{l}\text { Tricolporate, perreticulate, equat. oblate/prolate, } 16-33 x \\
27-40 \mu \mathrm{m}\end{array}$ & EC, CV, ANT \\
\hline 2 & Alstroemeriaceae & Bomarea & Páramo & Monosulcate, reticulate, size ca. $23 \times 55 \mu \mathrm{m}$ & ANT \\
\hline 3 & Amaranthaceae & Alternanthera & Páramo & $\begin{array}{l}\text { Fenestrate, periporate, (micro-)echinate, circular. Size ca. } \\
20-22 \mu \mathrm{m}\end{array}$ & EC, CV, ANT \\
\hline 4 & Apiaceae & Apiaceae & Páramo & $\begin{array}{l}\text { Tricolporate, psilate, equat. subprolate-prolate. Size ca. } 25 \\
\mu \mathrm{m}\end{array}$ & EC, CV, ANT \\
\hline 5 & Aquifoliaceae & Ilex & UMF & $\begin{array}{l}\text { Tricolporate, clavate, equat. (sub)prolate. Size ca. 21- } \\
31 \times 30-40 \mu \mathrm{m}\end{array}$ & EC, CV, ANT \\
\hline 6 & Araliaceae & Oreopanax & LMF & $\begin{array}{l}\text { Tricolporate, (micro-) reticulate, equat. Subprolate. Size ca. } \\
30-45 \mu \mathrm{m}\end{array}$ & EC, CV, ANT \\
\hline 7 & Asteraceae & Baccharis type & Subpáramo/Páramo & Tricolporate, echinate, circular. Size ca. $28-40 \mu \mathrm{m}$ & EC, CV, ANT \\
\hline 8 & Asteraceae & cf. Ambrosia & Subpáramo/Páramo & $\begin{array}{l}\text { Tricolporate, (micro-)echinate, equat. circular, } \\
\text { polar.suboblate. Size } 11-16 \text { × 15-25 } \mu \mathrm{m}\end{array}$ & EC, CV, ANT \\
\hline 9 & Asteraceae & Gynoxys type & Subpáramo/Páramo & Tricolporate, echinate, circular. Size ca. 35-40 $\mu \mathrm{m}$ & $\mathrm{EC}, \mathrm{CV}$ \\
\hline 10 & Asteraceae & Senecio & Subpáramo/Páramo & $\begin{array}{l}\text { Tricolporate, echinate, equat. Subprolate }(25-40 \mu \mathrm{m}) \text {, polar } \\
\text { circular }(28-45 \mu \mathrm{m})\end{array}$ & EC, CV, ANT \\
\hline 11 & $\begin{array}{l}\text { Asteraceae subf. } \\
\text { Cichorioideae }\end{array}$ & $\begin{array}{l}\text { Asteraceae subf. } \\
\text { Cichorioideae }\end{array}$ & Subpáramo/Páramo & Tricolporate, equinate, different types & EC, CV, ANT \\
\hline 12 & Betulaceae & Alnus acuminata & UMF & Stephanoporate (5 (4) pore), psilate, polar (20-35 $\mu \mathrm{m})$ & EC, CV, ANT \\
\hline 13 & Boraginaceae & Boraginaceae & Páramo & $\begin{array}{l}\text { Stephanocolporate (4 pores), psilate-scabrate, circular. Size } \\
15-20 \mu \mathrm{m}\end{array}$ & ANT \\
\hline 14 & Brassicaceae & Brassicaceae & Páramo & $\begin{array}{l}\text { Tricolporate, reticulate, polar circular/trilobate. Size ca. 25- } \\
38 \mu \mathrm{m}\end{array}$ & EC, CV, ANT \\
\hline 15 & Bromeliaceae & Bromeliaceae & Páramo & $\begin{array}{l}\text { Monosulcate, sulcus long and broad, reticulate, different } \\
\text { types }\end{array}$ & EC, CV, ANT \\
\hline 16 & Campanulaceae & Campanulaceae & Subpáramo & $\begin{array}{l}\text { Tricolporate, psilate/scabrate/(micro) reticulate, different } \\
\text { types }\end{array}$ & $\mathrm{CV}$ \\
\hline
\end{tabular}




\begin{tabular}{|c|c|c|c|c|c|}
\hline $\begin{array}{l}\text { Photo } \\
\text { No. }\end{array}$ & Family & Pollen & Vegetation type & Morphology & Record \\
\hline 17 & Campanulaceae & Centropogon type & Páramo & Tricolporate, psilate, circular. Size ca. 45 × $60 \mu \mathrm{m}$ & EC \\
\hline 18 & Caprifoliaceae & Valeriana type & Páramo & Tricolpate, micro-echinate, circular ca. $35-40 \mu \mathrm{m}$ & EC, CV, ANT \\
\hline 19 & Caryophyllaceae & Caryophyllaceae & Páramo & Periporate, scabrate, circular. Size ca. $25-40 \mu \mathrm{m}$ & EC, CV, ANT \\
\hline 20 & Chenopodiaceae & Chenopodiaceae & Páramo & $\begin{array}{l}\text { Periporate, micro/per/suprareticulate, subspheroidal. Size } \\
18-32 \mu \mathrm{m}\end{array}$ & ANT \\
\hline 21 & Chloranthaceae & Hedyosmum & UMF & Inaperturate, clavate/baculate, circular. Size 25 - 41 m & EC, CV, ANT \\
\hline 22 & Clethraceae & Clethra & UMF/Subpáramo & $\begin{array}{l}\text { Tricolporate, psilate-scabrate, equat. spheroidal to prolate. } \\
\text { Size } 10-14 \times 11-14 \mu \mathrm{m}\end{array}$ & EC, CV, ANT \\
\hline 23 & Clethraceae & Purdiaea nutans & UMF/Subpáramo & $\begin{array}{l}\text { Tricolporate, psilate, pore area stick out laterally, equat. } \\
(10-17 \mu \mathrm{m}) \text {, polar }(9-16 \mu \mathrm{m})\end{array}$ & EC, CV, ANT \\
\hline 24 & Clusiaceae & Clusia & LMF & Tricolporate, reticulate circular. Size ca. 21-30 x 28-36 $\mu \mathrm{m}$ & $\mathrm{EC}, \mathrm{CV}$ \\
\hline 25 & Cunoniaceae & Weinmannia & UMF & $\begin{array}{l}\text { Tricolporate, (micro-/per-) reticulate, equat. Prolate. Size } \\
\text { ca. } 7-12 \times 11-20 \mu \mathrm{m}\end{array}$ & EC, CV, ANT \\
\hline 26 & Cyperaceae & Cyperaceae & Páramo & $\begin{array}{l}\text { Periporate,psilate to scabrate, pores indistinct, } \\
\text { subspheroidal }\end{array}$ & EC, CV, ANT \\
\hline 27 & Elaeocarpaceae & Vallea & UMF & $\begin{array}{l}\text { Tricolporate, psilate, equat. subprolate to prolate. Size 7-10 } \\
x 10-13 \mu \mathrm{m}\end{array}$ & EC, CV, ANT \\
\hline 28 & cf Ericaceae psilate & cf Ericaceae psilate & Subpáramo/Páramo & Tricolporate, tetrad, psilate to scabrate. Size ca. $20-45 \mu \mathrm{m}$ & CV, ANT \\
\hline 29 & Ericaceae & Ericaceae & Subpáramo/Páramo & Tricolporate, tetrad, psilate to scabrate, different types & EC, CV, ANT \\
\hline 30 & Escalloniaceae & Escallonia type & UMF & Tricolporate, scabrate. Size ca. $10-15 \mu \mathrm{m}$ & $\mathrm{EC}, \mathrm{CV}$ \\
\hline 31 & Euphorbiaceae & Acalypha & LMF & Stephanocolporate (4-5), scabrate. Size ca. 21-23 $\mu \mathrm{m}$ & EC, CV, ANT \\
\hline 32 & Euphorbiaceae & Alchornea & LMF & $\begin{array}{l}\text { Tricolporate, fine scabrate to perforate, equat. Oblate to } \\
\text { prolate. Size ca. } 20-30 \mu \mathrm{m}\end{array}$ & EC, CV, ANT \\
\hline 33 & Euphorbiaceae & Euphorbiaceae & Other & Tricolporate, reticulate, different types & CV, ANT \\
\hline
\end{tabular}




\begin{tabular}{|c|c|c|c|c|c|}
\hline $\begin{array}{l}\text { Photo } \\
\text { No. }\end{array}$ & Family & Pollen & Vegetation type & Morphology & Record \\
\hline 34 & Euphorbiaceae & Hyeronima & LMF & $\begin{array}{l}\text { Tricolporate, reticulate, equat.(per-)prolate }(22-34 \mu \mathrm{m}) \text {, } \\
\text { polar circular }(8-13 \mu \mathrm{m})\end{array}$ & $\mathrm{EC}, \mathrm{CV}, \mathrm{ANT}$ \\
\hline 35 & Fabaceae & Fabaceae & Páramo & $\begin{array}{l}\text { Tricolporate, psilate to (micro) reticulate, mostly unique big } \\
\text { pores, equat. Subprolate, different types }\end{array}$ & EC, CV, ANT \\
\hline 36 & Flacourtiaceae & Flacourtiaceae & UMF & $\begin{array}{l}\text { 4-colporate, psilate, equat. oblate }(28-38 \mu \mathrm{m}) \text {, polar } \\
\text { circular }\end{array}$ & CV \\
\hline 37 & Gentianaceae & Gentiana & Páramo & Tricolporate, clavate/pilate. Size ca. $30-40 \mu \mathrm{m}$ & ANT \\
\hline 38 & Gentianaceae & Gentianaceae & Páramo & $\begin{array}{l}\text { Tricolporate, reticulate, equat. Subprolate }(30-40 \mu \mathrm{m}) \text {, } \\
\text { polar circular }(25-35 \mu \mathrm{m})\end{array}$ & $\mathrm{EC}, \mathrm{CV}, \mathrm{ANT}$ \\
\hline 39 & Gentianaceae & Gentianella & Páramo & $\begin{array}{l}\text { Tricolporate, reticulate, equat. }(30-40 \mu \mathrm{m}) \text {, polar circular } \\
(25-35 \mu \mathrm{m})\end{array}$ & CV \\
\hline 40 & Gentianaceae & Macrocarpaea & UMF & $\begin{array}{l}\text { Tricolporate, hetero-reticulate, muri ca. } 2 \mu \mathrm{m} \text {, circular ca. } \\
25-30 \mu \mathrm{m}\end{array}$ & $\mathrm{EC}, \mathrm{CV}, \mathrm{ANT}$ \\
\hline 41 & Geraniaceae & Geranium & Páramo & $\begin{array}{l}\text { Tricolpate, per-reticulate/clavate, circular/spheroidal } 60 \text { - } \\
100 \mu \mathrm{m}\end{array}$ & $\mathrm{EC}, \mathrm{CV}, \mathrm{ANT}$ \\
\hline 42 & Gunneraceae & Gunnera & Subpáramo/Páramo & $\begin{array}{l}\text { Tricolpate, micro-/per-reticulate, equat. spheroidal, polar } \\
\text { trilobate. Size ca. } 23 \text { - } 38 \mu \mathrm{m}\end{array}$ & $\mathrm{EC}, \mathrm{CV}, \mathrm{ANT}$ \\
\hline 43 & Hypericaceae & Hypericum & Subpáramo/Páramo & $\begin{array}{l}\text { Tricolporate, (micro-)reticulate, slightly constricted at the } \\
\text { equator. Size ca. } 14-21 \times 24-35 \mu \mathrm{m}\end{array}$ & $\mathrm{EC}, \mathrm{CV}, \mathrm{ANT}$ \\
\hline 44 & Iridaceae & Iridaceae & Páramo & $\begin{array}{l}\text { Ticolpate/monosulcate, psilate/(micro) reticulate, } \\
\text { differente types }\end{array}$ & $\mathrm{EC}, \mathrm{CV}, \mathrm{ANT}$ \\
\hline 45 & Lamiaceae & Lamiaceae & UMF/Páramo & $\begin{array}{l}\text { Stephanocolpate (6 colpi), reticulate/scabrate, polar } \\
\text { circular ca. } 40-50 \mu \mathrm{m}\end{array}$ & CV, ANT \\
\hline 46 & Loranthaceae & Loranthaceae & UMF/Subpáramo & Syncolporate, mostly psilate, different types & EC, CV, ANT \\
\hline 47 & Malpighiaceae & Malphigia & UMF & Ticolporate, psilate, equat. Circular. Size ca. 25 - $30 \mu \mathrm{m}$ & CV \\
\hline 48 & Malpighiaceae & Malpighiaceae & UMF & $\begin{array}{l}\text { Periporate, scabrate, heteropolar, spheroidal, different } \\
\text { types }\end{array}$ & CV \\
\hline
\end{tabular}




\begin{tabular}{|c|c|c|c|c|c|}
\hline $\begin{array}{l}\text { Photo } \\
\text { No. }\end{array}$ & Family & Pollen & Vegetation type & Morphology & Record \\
\hline 49 & Melastomataceae & Melastomataceae & $\begin{array}{l}\text { UMF/Subpáramo/Páram } \\
\text { o }\end{array}$ & $\begin{array}{l}\text { Heterocolporate, } 3 \text { colpi/3 pseudocolpi, equat. prolate to } \\
\text { perprolate. Size } 10-20 \text { to } 20-22 \mu \mathrm{m}\end{array}$ & $\mathrm{EC}, \mathrm{CV}, \mathrm{ANT}$ \\
\hline 50 & Meliaceae & Ruagea & Páramo & $\begin{array}{l}\text { Stephanocolporate ( } 4 \text { apertures), psilate to fine scabrate, } \\
\text { polar elliptic/circular. Size ca. } 30-40 \mu\end{array}$ & CV, ANT \\
\hline 51 & Mimosaceae & Mimosaceae & LMF & Polyad (44), scabrate, circular ca. 25-30 $\mu \mathrm{m}$, different types & EC, CV, ANT \\
\hline 52 & $\begin{array}{l}\text { Moraceae/Urticace } \\
\text { ae }\end{array}$ & $\begin{array}{l}\text { Moraceae/Urticace } \\
\text { ae }\end{array}$ & LMF & $\begin{array}{l}\text { Diporate/triporate, psilate to fine scabrate, circular ca. } 20 \text { - } \\
25 \mu \mathrm{m}\end{array}$ & EC, CV, ANT \\
\hline 53 & Myrsinaceae & Myrsine & UMF & $\begin{array}{l}\text { (3-)4(-5)colpate, psilate-scabrate, equat. Circular } 16-20 \\
\mu \mathrm{m}, \text { polar quadrangular } 18-25 \mu \mathrm{m}\end{array}$ & EC, CV, ANT \\
\hline 54 & Myrtaceae & Myrica & UMF & $\begin{array}{l}\text { Triporate, scabrate/rugulate, subtriangular convex, polar } \\
\text { ca. } 25-40 \mu \mathrm{m}\end{array}$ & $\mathrm{EC}, \mathrm{CV}, \mathrm{ANT}$ \\
\hline 55 & Myrtaceae & Myrtaceae & UMF & $\begin{array}{l}\text { Syncolpate (3), psilate to sacabrate/micro-reticulate, } \\
\text { subtriangular convex. Size } 21-25 \mu \mathrm{m}\end{array}$ & EC, CV, ANT \\
\hline 56 & Oxalidaceae & Oxalis & Subpáramo & $\begin{array}{l}\text { Tricolpate, reticulate, equat. (sub)prolate }(26-38 \mu \mathrm{m}) \text {, } \\
\text { polar circular }(22-28 \mu \mathrm{m})\end{array}$ & EC, CV, ANT \\
\hline 57 & Phytolaccaceae & Phytolacca & UMF & Ticolporate, reticulate. Size 20 - $25 \mu \mathrm{m}$ & CV \\
\hline 58 & Pinaceae & Pinus & UMF/LMF & $\begin{array}{l}\text { Disaccate, corpus scabrate to rugulate, airsaccats with per- } \\
\text { reticulum, corpus 50-64 } \mu \mathrm{m} \text { long and } 41-64 \mu \mathrm{m} \text { wide, air } \\
\text { saccats } 39-51 \mu \mathrm{m} \text { long and 55-68 } \mu \mathrm{m} \text { wide }\end{array}$ & CV, ANT \\
\hline 59 & Piperaceae & Piper & LMF & Monocolpate, psilate, intectate, 5-78-12 m & EC, CV, ANT \\
\hline 60 & Plantaginaceae & Plantago australis & Páramo & $\begin{array}{l}\text { Periporate (8-14 pores), verrucate irregular, } \\
\text { circular/spheroidal. Size } 18-42 \mu \mathrm{m}\end{array}$ & $\mathrm{EC}, \mathrm{CV}, \mathrm{ANT}$ \\
\hline 61 & Plantaginaceae & Plantago rigida & Páramo & $\begin{array}{l}\text { Periporate, scabrate/reticulate, equat. Circular (28 - } 35 \\
\mu \mathrm{m}), \text { polar }(28-35 \mu \mathrm{m})\end{array}$ & EC, CV, ANT \\
\hline 62 & Poaceae & Poaceae & Páramo & $\begin{array}{l}\text { Monoporate, psilate to fine-scabrate, pore with distinct } \\
\text { annulus, circular ca. }(22-60 \mu \mathrm{m})\end{array}$ & $\mathrm{EC}, \mathrm{CV}, \mathrm{ANT}$ \\
\hline 63 & Poaceae & Zea mays & Páramo & $\begin{array}{l}\text { Monoporate, psilate, pore } 4-8 \mu \mathrm{m} \text { with annulus, circular } \\
(80-100 \mu \mathrm{m})\end{array}$ & ANT \\
\hline
\end{tabular}




\begin{tabular}{|c|c|c|c|c|c|}
\hline $\begin{array}{l}\text { Photo } \\
\text { No. }\end{array}$ & Family & Pollen & Vegetation type & Morphology & Record \\
\hline 64 & Podocarpaceae & Podocarpaceae & UMF & $\begin{array}{l}\text { Disaccate, air saccats globose and reticulate, corpus length } \\
\text { ca. } 30-55 \mu \mathrm{m} \text { and saccus width ca. } 23-47 \mu \mathrm{m} \text {, grain length } \\
\text { ca. } 50-80 \mu \mathrm{m}\end{array}$ & EC, CV, ANT \\
\hline 65 & Polygalaceae & Monnina & UMF/Páramo & $\begin{array}{l}\text { Stephanocolporate (11-14 apertures), foveolate, } \\
\text { subprolate/prolate. Size } 30-45 \mu \mathrm{m}\end{array}$ & $\mathrm{EC}, \mathrm{CV}, \mathrm{ANT}$ \\
\hline 66 & Polygonaceae & $\begin{array}{l}\text { Muehlenbeckia/Ru } \\
\text { mex type }\end{array}$ & Subpáramo/Páramo & $\begin{array}{l}\text { Tricolporate, reticulate, suboblate to prolate-spheroidal. } \\
\text { Size } 18-25 \times 17-24\end{array}$ & EC, CV, ANT \\
\hline 67 & Proteaceae & Proteaceae & LMF & $\begin{array}{l}\text { Triporate, (micro-/per-) reticulate, subtriangular. Size ca. } 19 \\
\text { - } 31 \mu \mathrm{m} \text { diam. }\end{array}$ & $\mathrm{EC}, \mathrm{CV}$ \\
\hline 68 & Ranunculaceae & Ranunculus & Páramo & Tricolpate, echinate, circular. Size ca. 21-27 $\mu \mathrm{m}$ & $\mathrm{EC}, \mathrm{CV}$ \\
\hline 69 & Rosaceae & Polylepis & UMF & $\begin{array}{l}\text { Tricolporate, verrucate, pores with an loose operculum, } \\
\text { circular. Size } 20-41 \mu \mathrm{m}\end{array}$ & EC, CV, ANT \\
\hline 70 & Rosaceae & Rosaceae & Páramo & $\begin{array}{l}\text { Tricolporate, striate, equat. Prolate. Size } 12-20 \mu \mathrm{m} \text {, } \\
\text { different types }\end{array}$ & $\mathrm{EC}, \mathrm{CV}, \mathrm{ANT}$ \\
\hline 71 & Rubiaceae & Arcytophyllum & Páramo & $\begin{array}{l}\text { Tricolporate, reticulate, elongated, equat. } 30-38 \mu \mathrm{m} \text {, polar } \\
\text { circular } 25-23 \mu \mathrm{m}\end{array}$ & ANT \\
\hline 72 & Rubiaceae & Palicourea & LMF & Inaperturate, reticulate, circular & EC \\
\hline 73 & Rubiaceae & Rubiaceae & UMF & Tricolporate, reticulate different types & ANT \\
\hline 74 & Sapindaceae & Dodonaea & UMF & $\begin{array}{l}\text { Tricolporate, psilate/scabrate, prolate-spheroidal (25-30 } \\
\mu \mathrm{m})\end{array}$ & $\mathrm{EC}, \mathrm{CV}, \mathrm{ANT}$ \\
\hline 75 & Solanaceae & Solanum type & UMF & $\begin{array}{l}\text { Tricolporate, psilate, equat. suboblate/rhombic }(20-30 \\
\mu \mathrm{m}) \text {, polar circular }(19-18 \mu \mathrm{m})\end{array}$ & $\mathrm{EC}, \mathrm{CV}, \mathrm{ANT}$ \\
\hline 76 & Symplocaceae & $\begin{array}{l}\text { Symplocos } \\
\text { bogotensis type }\end{array}$ & UMF & Triporate, verrucate, triangular (convex). Size ca. 25-35 $\mu \mathrm{m}$ & $\mathrm{EC}, \mathrm{CV}, \mathrm{ANT}$ \\
\hline 77 & Symplocaceae & $\begin{array}{l}\text { Symplocos } \\
\text { canescens }\end{array}$ & UMF & $\begin{array}{l}\text { Diporate, psilate, pores circular with annulus, elliptic to } \\
\text { circular. Size ca. 20-35 } \mu \mathrm{m}\end{array}$ & $\mathrm{EC}, \mathrm{CV}, \mathrm{ANT}$ \\
\hline 78 & Symplocaceae & Symplocos type & UMF & Triporate, scabrate, triangular (convex). Size ca. 30-40 $\mu \mathrm{m}$ & EC, CV, ANT \\
\hline 79 & Tiliaceae & Tiliaceae & UMF & Tricolporate, reticulate, oblate, polar (ca. 43-50 $\mu \mathrm{m}$ ) & CV \\
\hline
\end{tabular}




\begin{tabular}{|c|c|c|c|c|c|}
\hline $\begin{array}{l}\text { Photo } \\
\text { No. }\end{array}$ & Family & Pollen & Vegetation type & Morphology & Record \\
\hline 80 & Ulmaceae & Celtis & UMF/LMF & Triporate, fine scabrate, subspheroidal. Size ca. 24-27 $\mu \mathrm{m}$ & EC, CV, ANT \\
\hline \multirow[t]{2}{*}{81} & Ulmaceae & Trema type & LMF & Diporate, psilate/scabrate. Size ca 13-17 x 15-20 $\mu \mathrm{m}$ & EC, CV, ANT \\
\hline & & & & Tricolporate, psilate/fine scabrate, equat. suboblate. Size ca. 35 & \\
\hline 82 & Verbenaceae & Verbena & LMF & $\mu \mathrm{m}$ & $\mathrm{EC}, \mathrm{CV}$ \\
\hline 83 & Xyridaceae & Xyris & Páramo & Dicolpate, reticulate, equat. prolate $(47-56 \mu \mathrm{m})$, polar $(20-33 \mu \mathrm{m})$ & $\mathrm{EC}, \mathrm{CV}$ \\
\hline
\end{tabular}

List of identified spores taxa grouped into the four major vegetation types

\begin{tabular}{|c|c|c|c|c|c|}
\hline $\begin{array}{l}\text { Photo } \\
\text { No. }\end{array}$ & Family & Spore & Vegetation type & Morphology & Record \\
\hline 1 & Cyatheaceae & Cyathea type & UMF/Páramo & $\begin{array}{l}\text { Trilete, scabrate to verrucate, triangluar concarve, equat. (> } 50 \\
\mu \mathrm{m})\end{array}$ & $\mathrm{EC}, \mathrm{CV}$ \\
\hline 2 & Isoetaceae & Isoetes & Páramo & $\begin{array}{l}\text { Monolete, scabrate/rugulate, long laesuae, elliptical ca. } 25-35 \mu \mathrm{m} \\
\text { long (with perine) }\end{array}$ & $\mathrm{EC}, \mathrm{CV}, \mathrm{ANT}$ \\
\hline 3 & Lycopodiaceae & Huperzia & Páramo & Trilete, verrucate/foveolate, triangular convex, equat. (35-50 $\mu \mathrm{m})$ & EC,CV,ANT \\
\hline 4 & Lycopodiaceae & Lycopodium jussiaei & Páramo & $\begin{array}{l}\text { Trilete, proximal psilate, distal with a spacious reticulum, } \\
\text { triangular convex, equat. diam. }(40-50 \mu \mathrm{m})\end{array}$ & ANT \\
\hline 5 & Osmundaceae & Osmunda & Páramo & 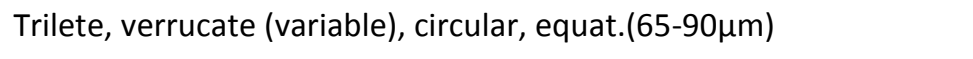 & EC,CV,ANT \\
\hline 6 & Pteridaceae & Jamesonia type & Páramo & $\begin{array}{l}\text { Trilete, verrucate (highly variable), mostly bordered by coarse } \\
\text { verrucate to rugulate, triangular (convex), equat. (ca. } 45-80 \mu \mathrm{m} \text { ) }\end{array}$ & $\mathrm{EC}, \mathrm{CV}, \mathrm{ANT}$ \\
\hline 7 & Sphagnaceae & Sphagnum & Páramo & $\begin{array}{l}\text { Trilete, psilate to scabrate to fine verrucate, triangular convex, } \\
\text { equat. }(30-40 \mu \mathrm{m})\end{array}$ & $\mathrm{CV}, \mathrm{ANT}$ \\
\hline
\end{tabular}




\section{Appendix}

Appendix B

1.2 Pollen and spores photo plates for the most common identified taxa 


\section{Pollen Plate 1}

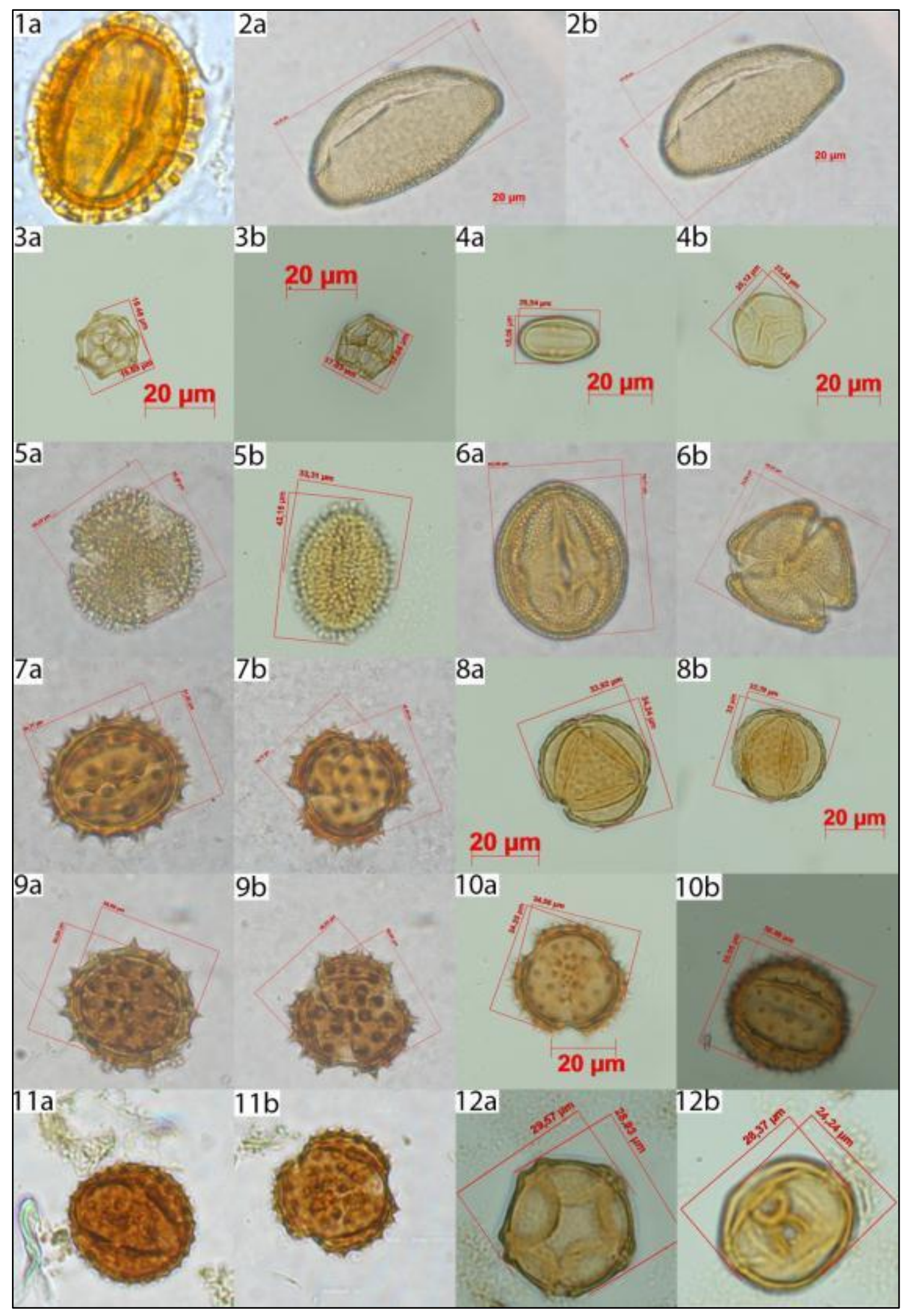




\section{Pollen Plate 2}

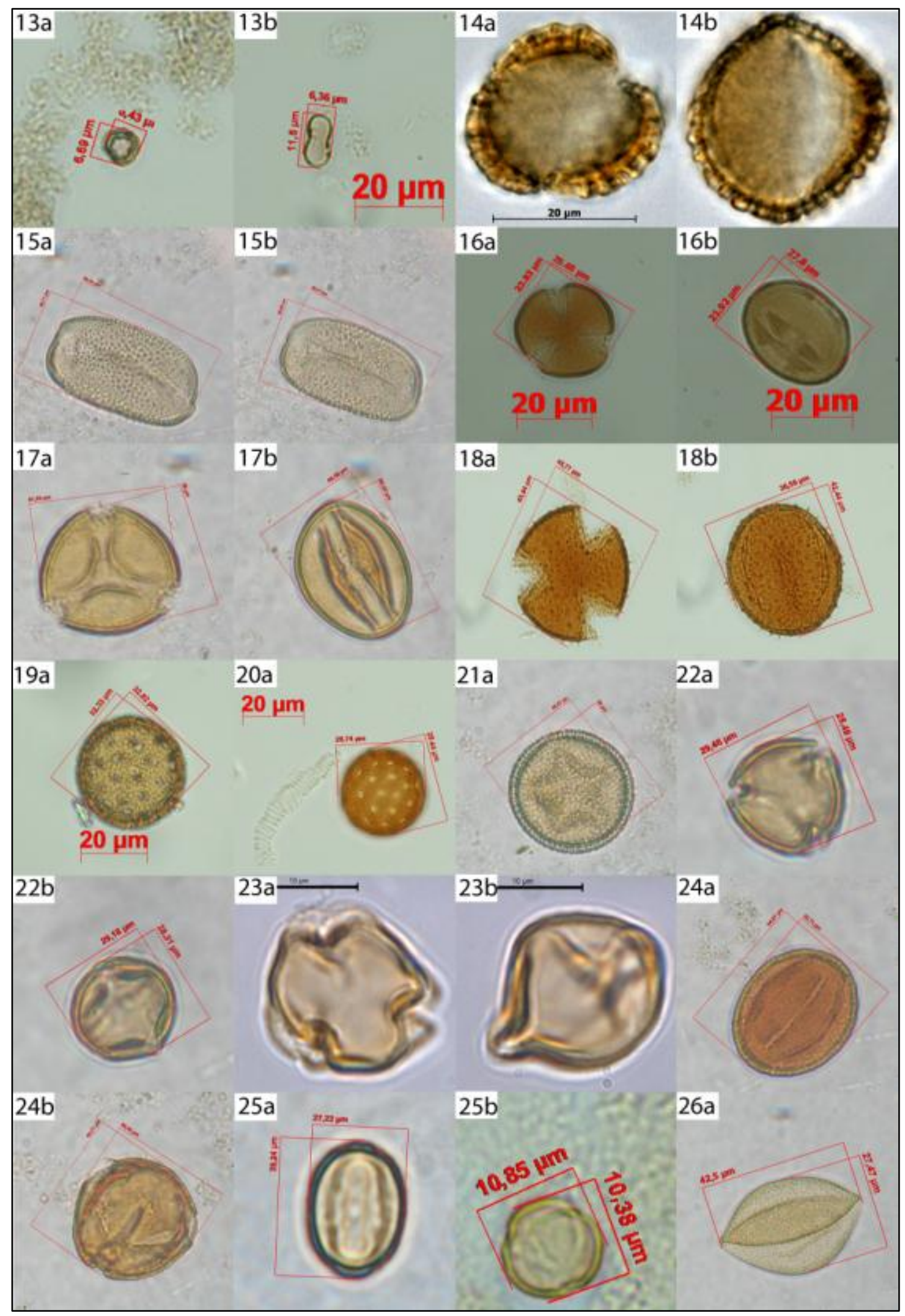




\section{Pollen Plate 3}

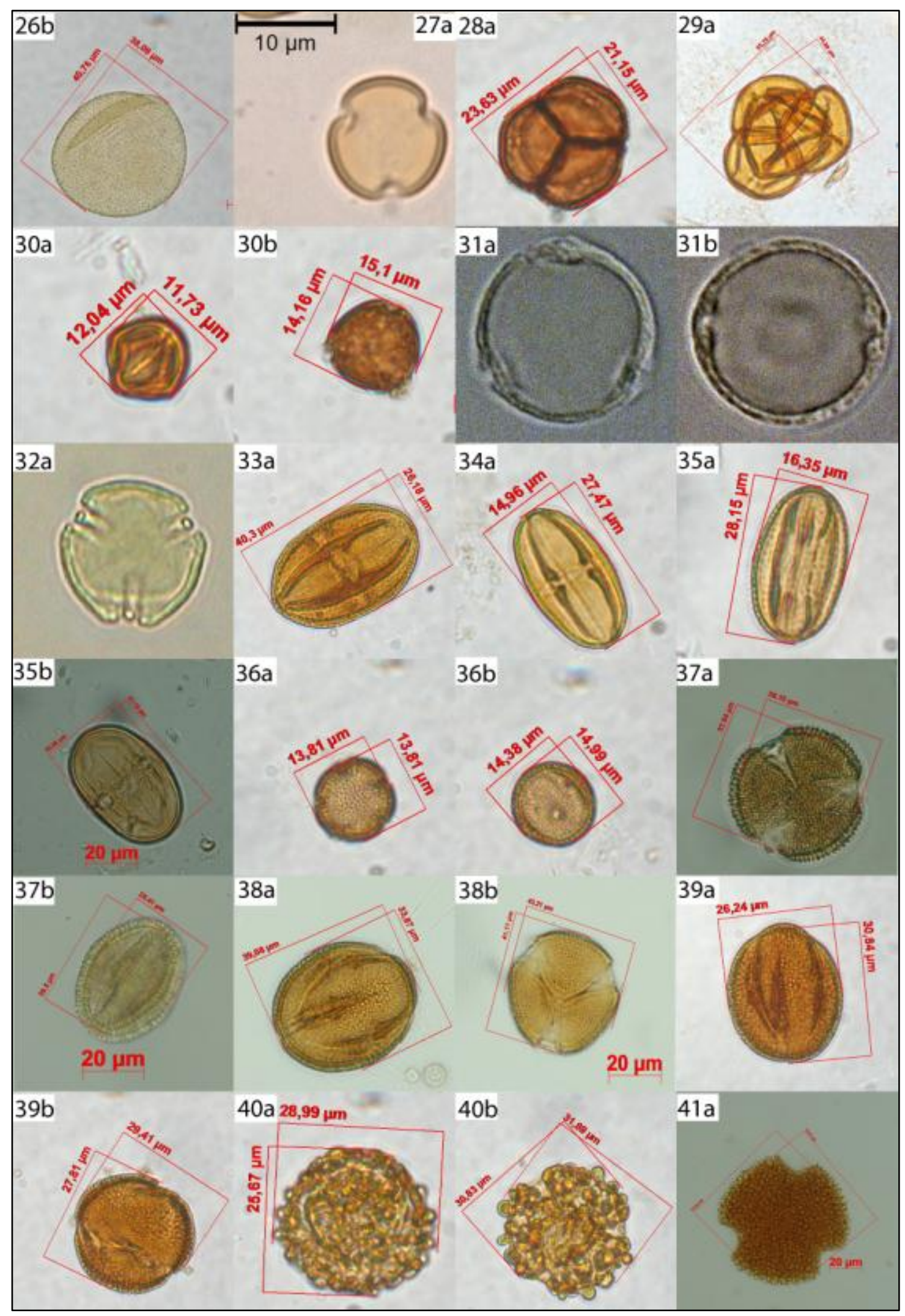




\section{Pollen Plate 4}

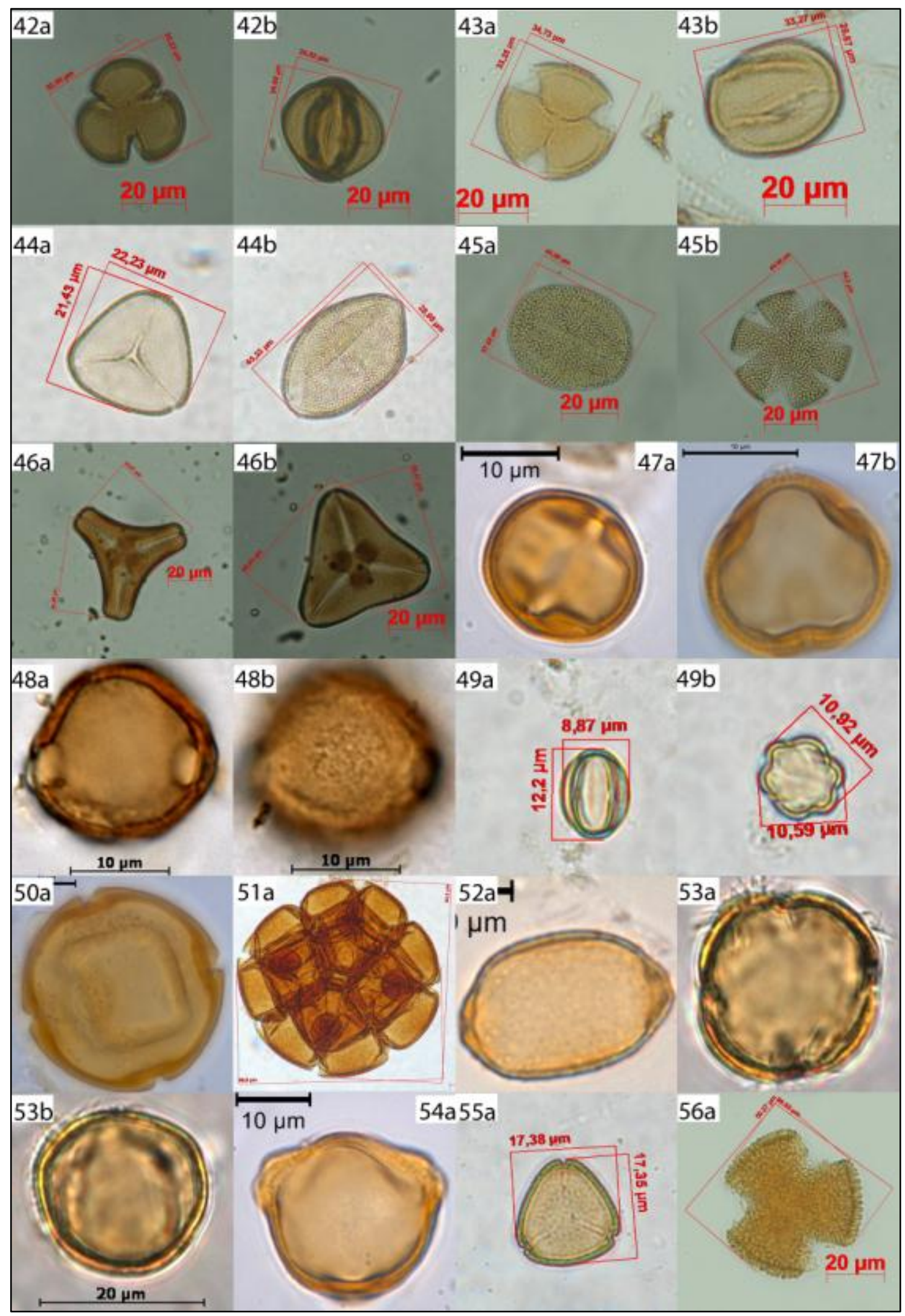




\section{Pollen Plate 5}

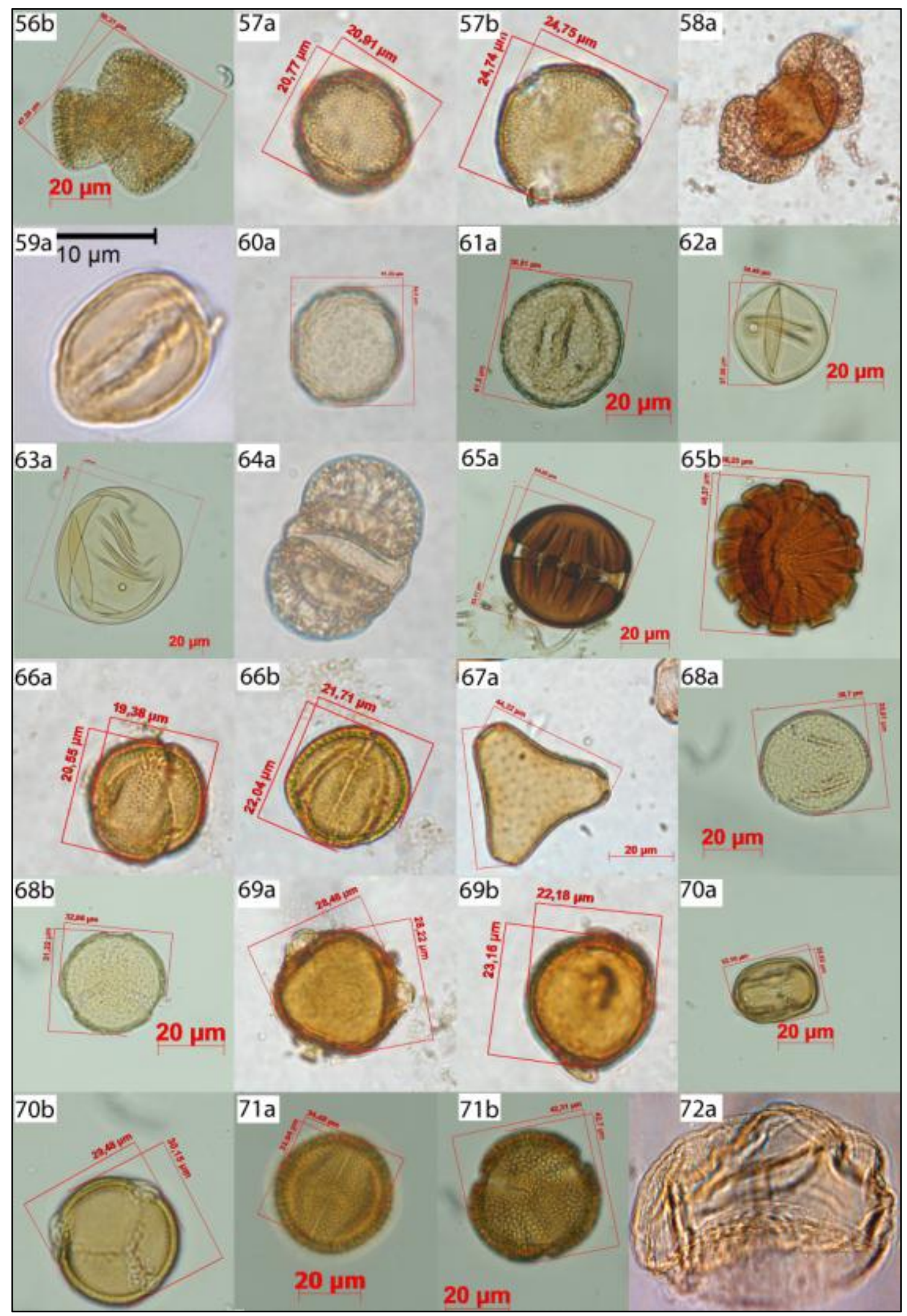




\section{Pollen Plate 6}

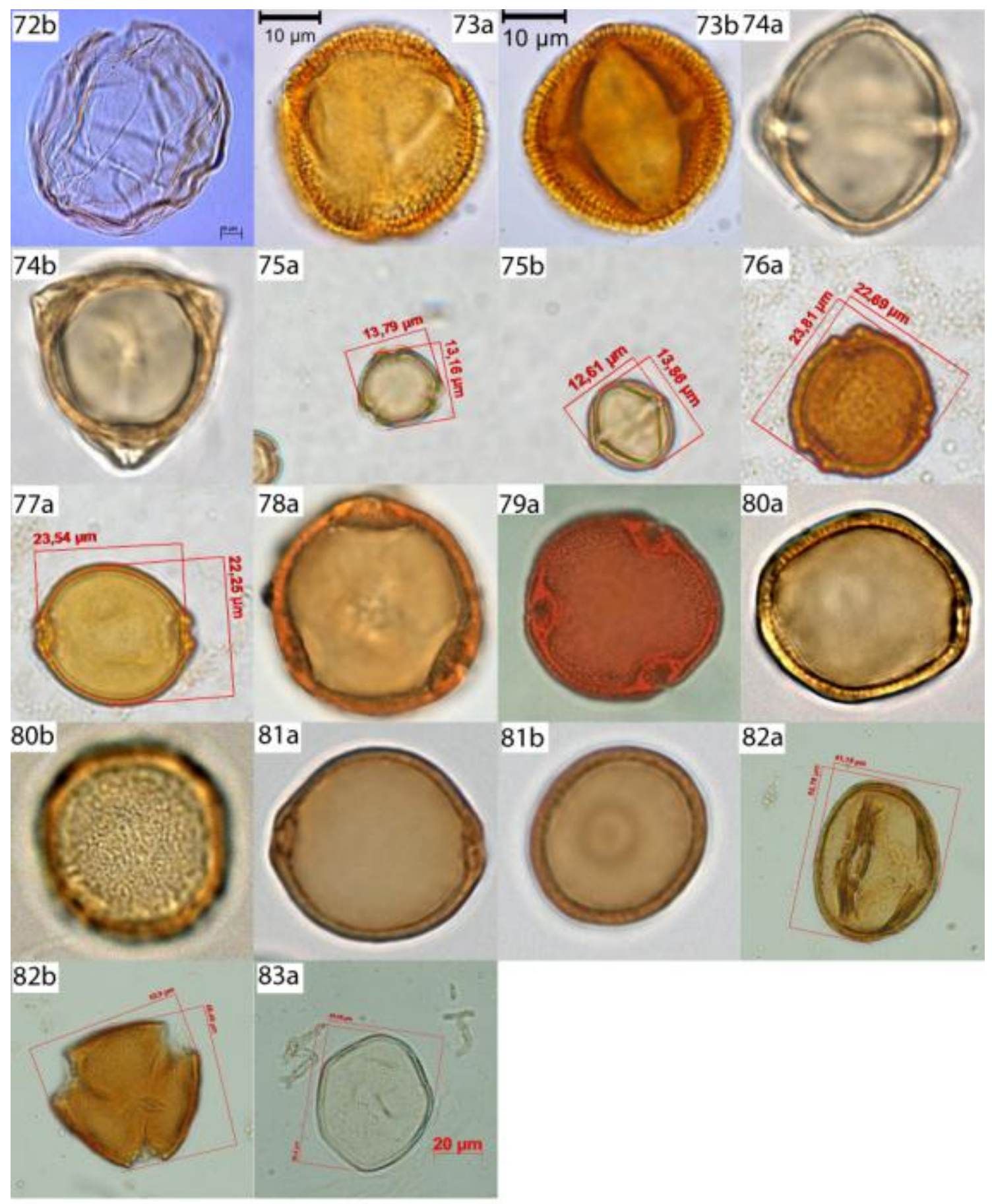




\section{Spore Plate 1}

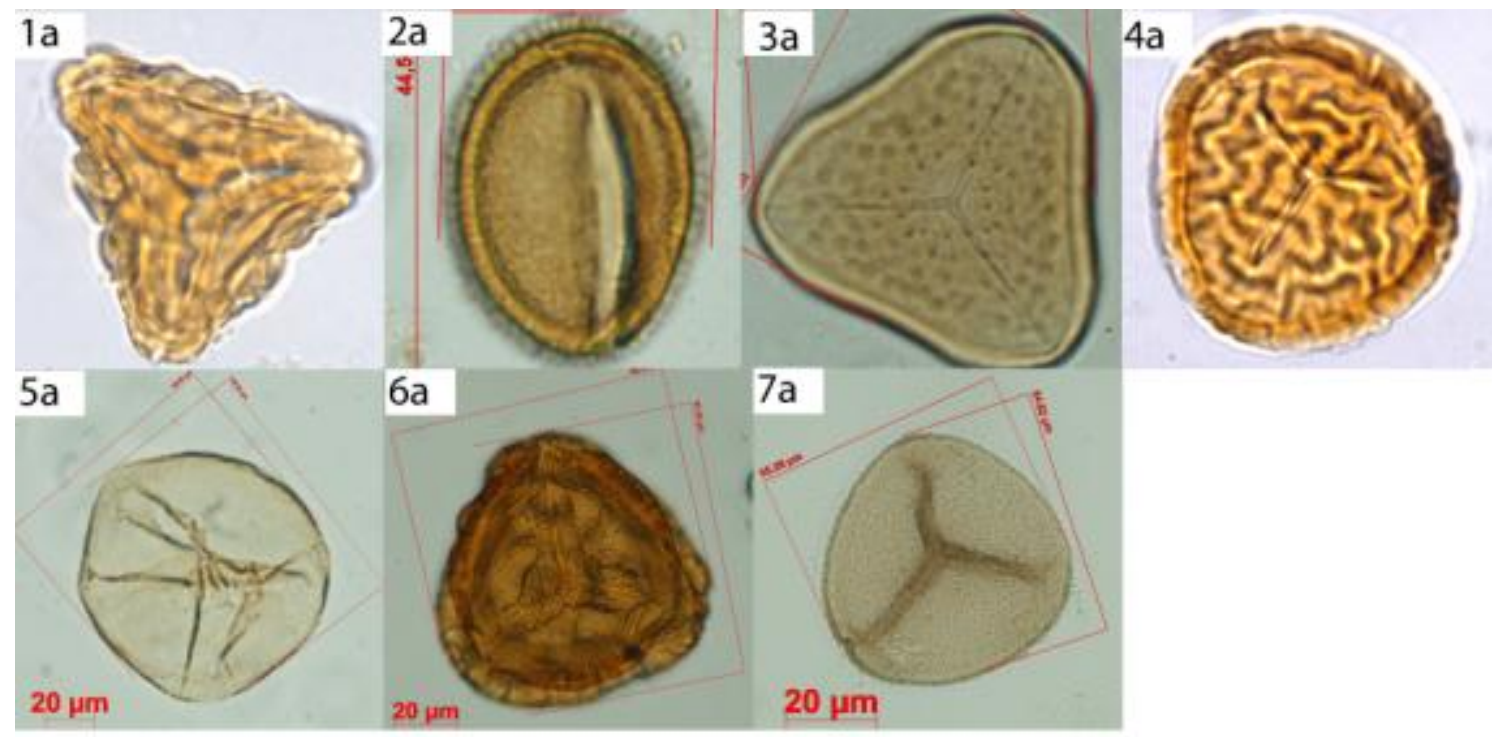




\section{Appendix}

\section{Appendix C}

1.3Complete palynological diagrams of identified pollen grains and spores for the three cores 


\subsubsection{El Cristal complete record percentage diagram}

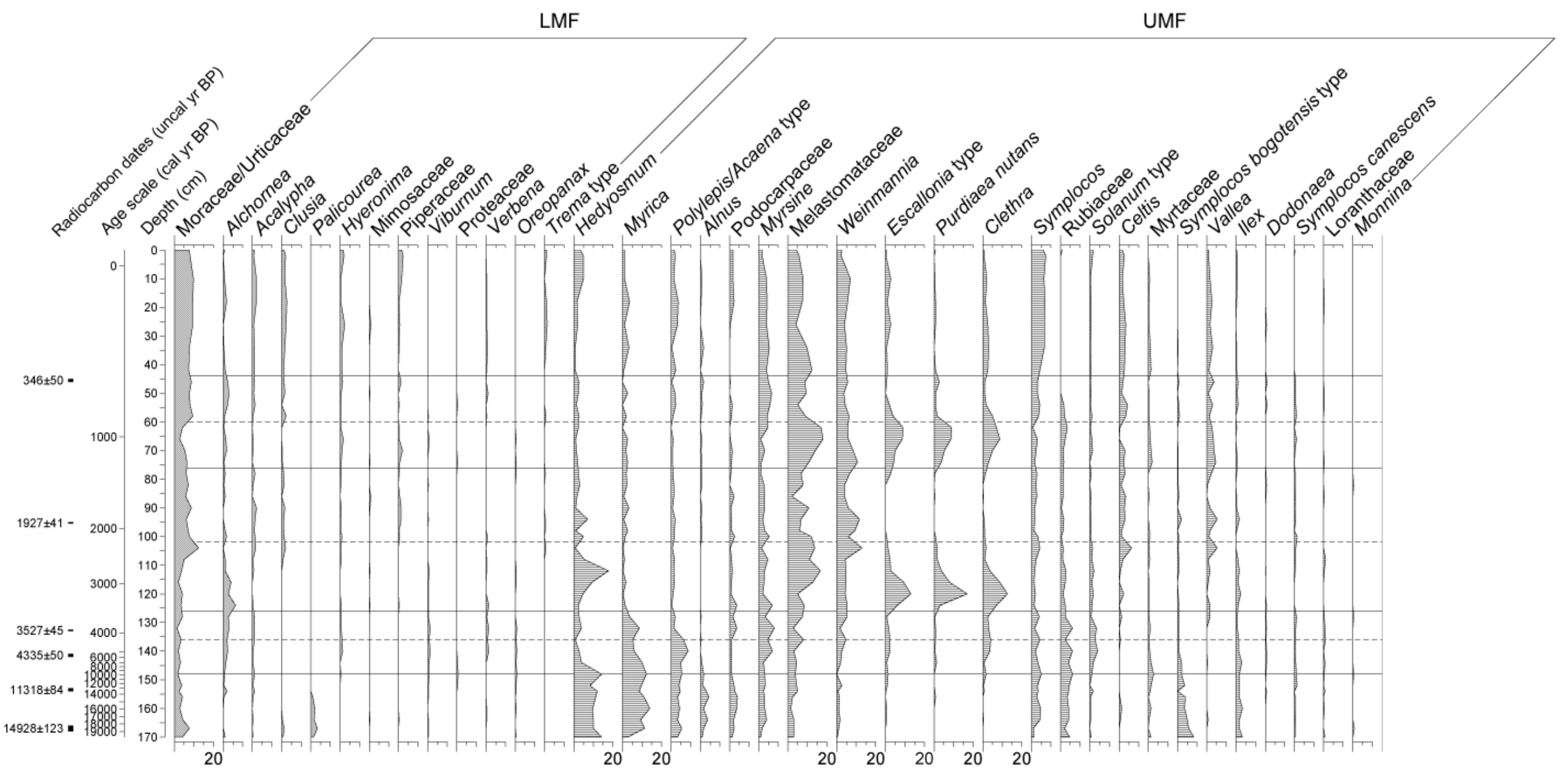




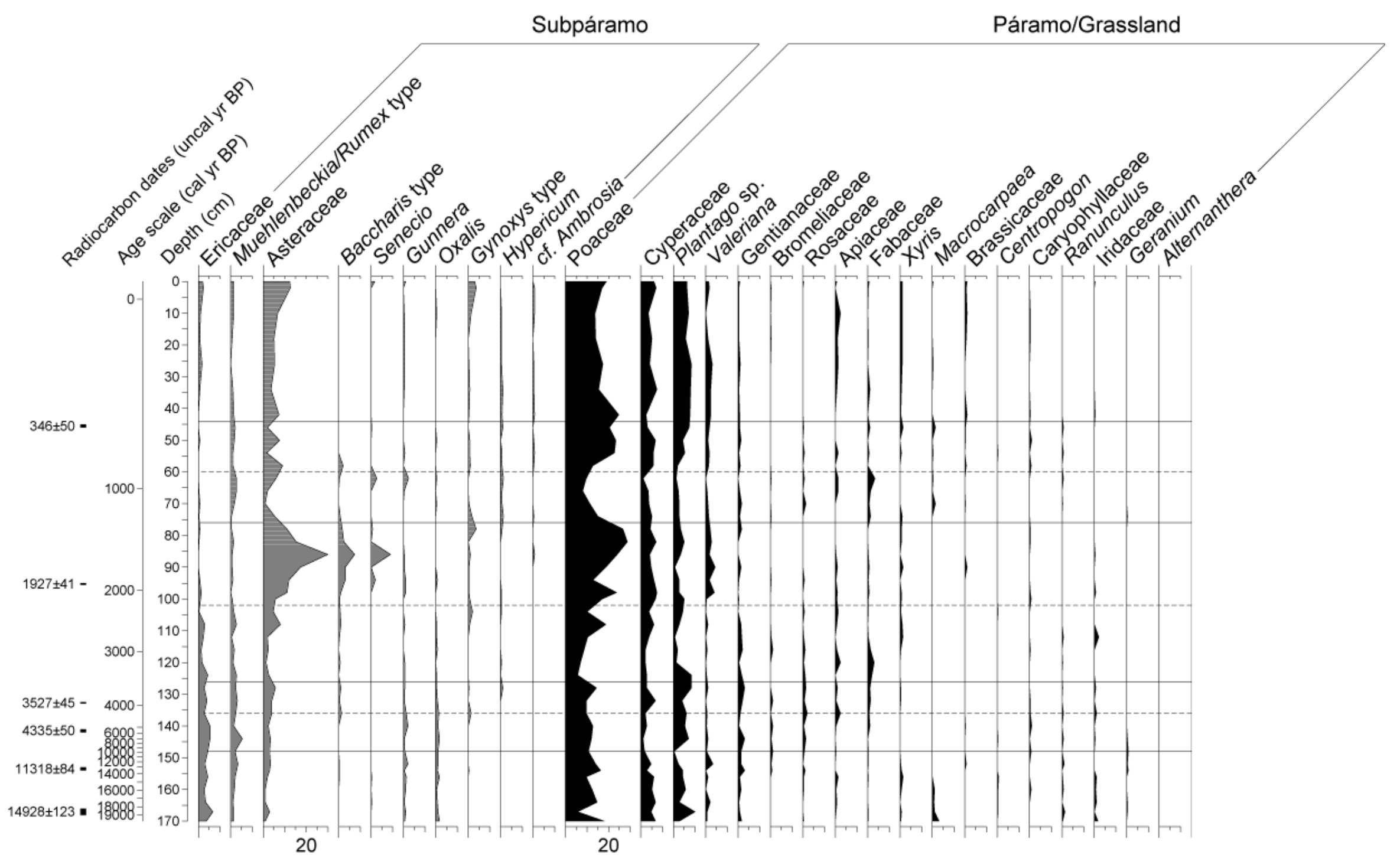




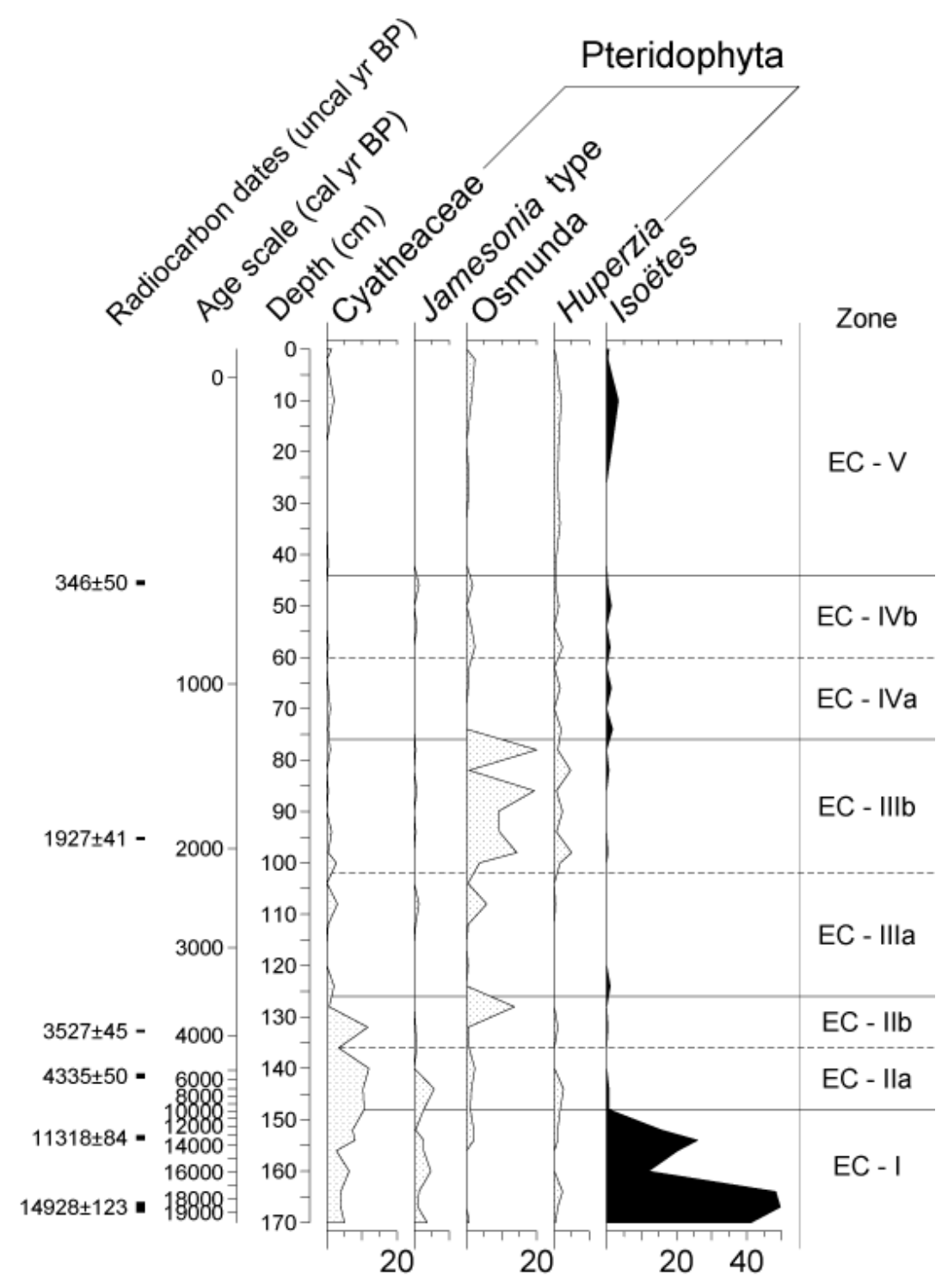




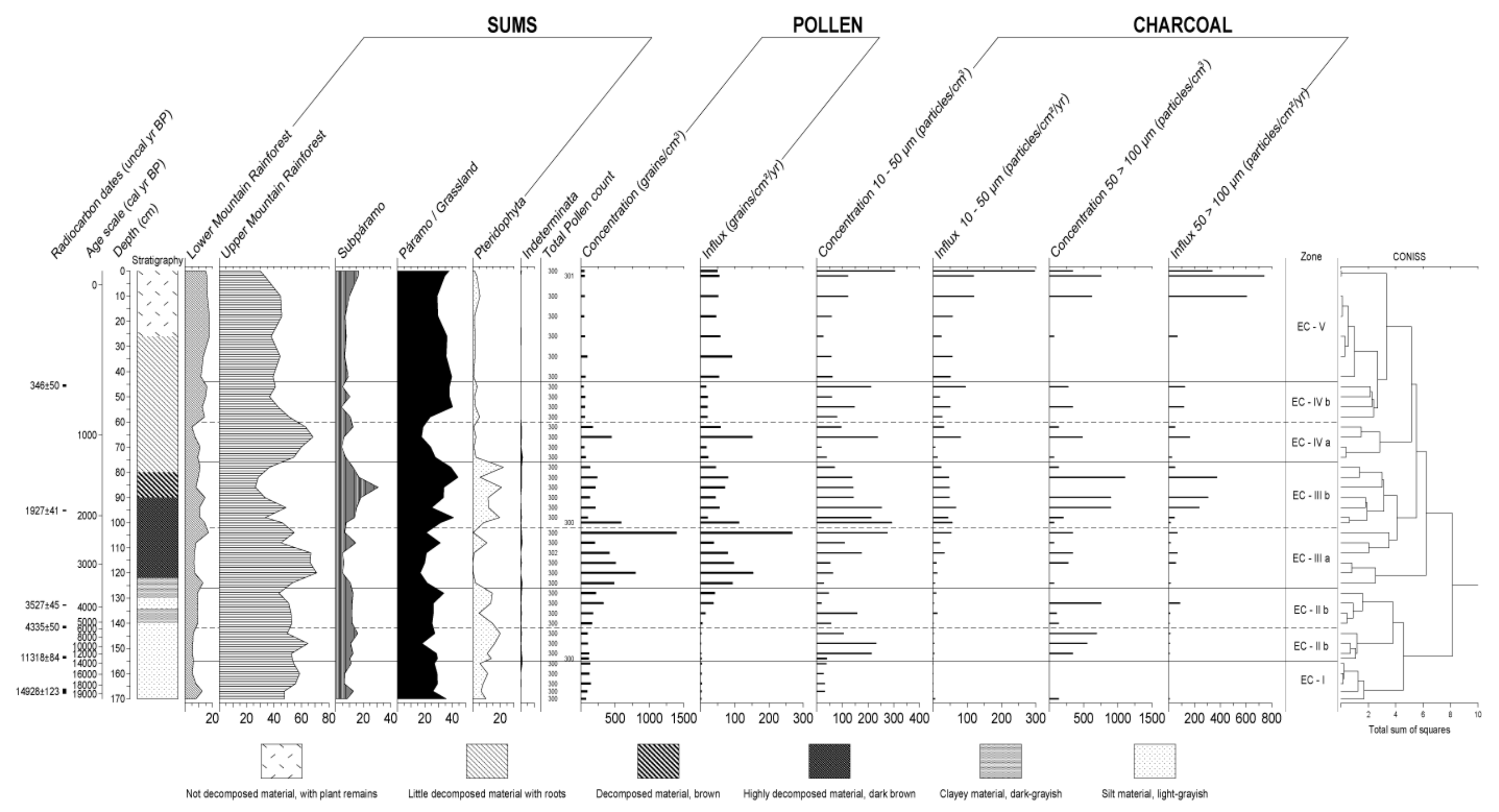




\subsubsection{Cajanuma valley complete record percentage diagram}

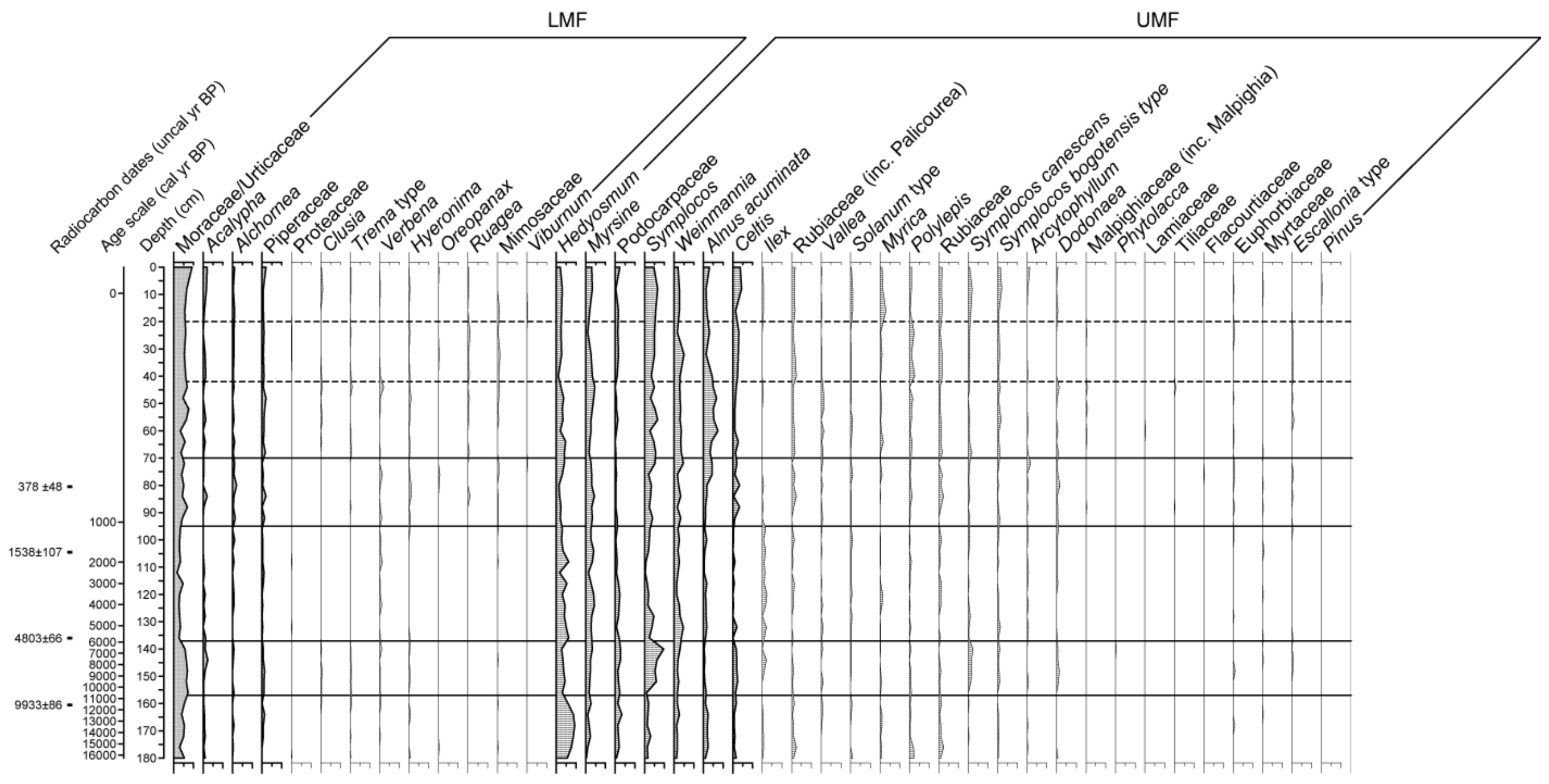




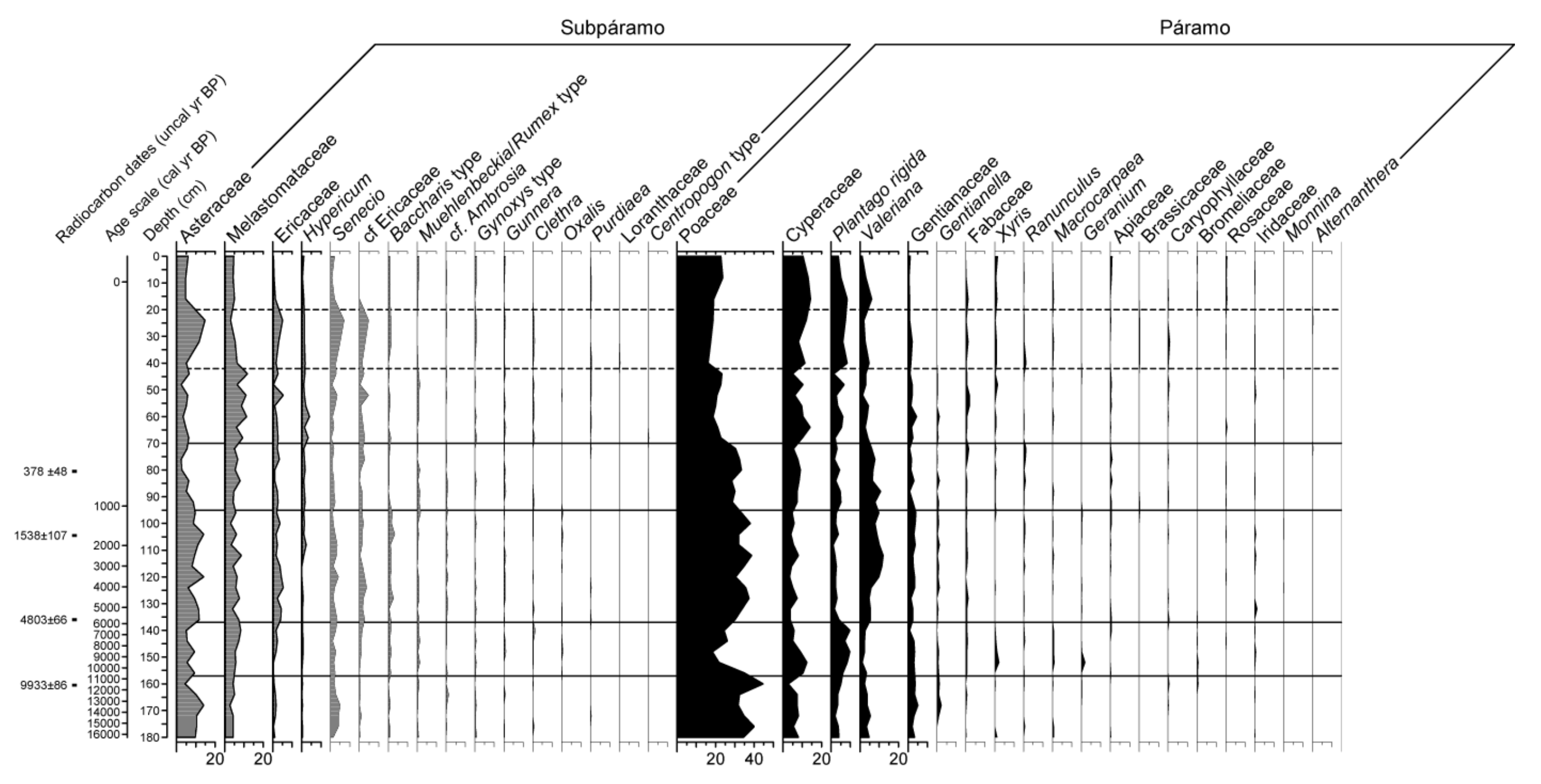




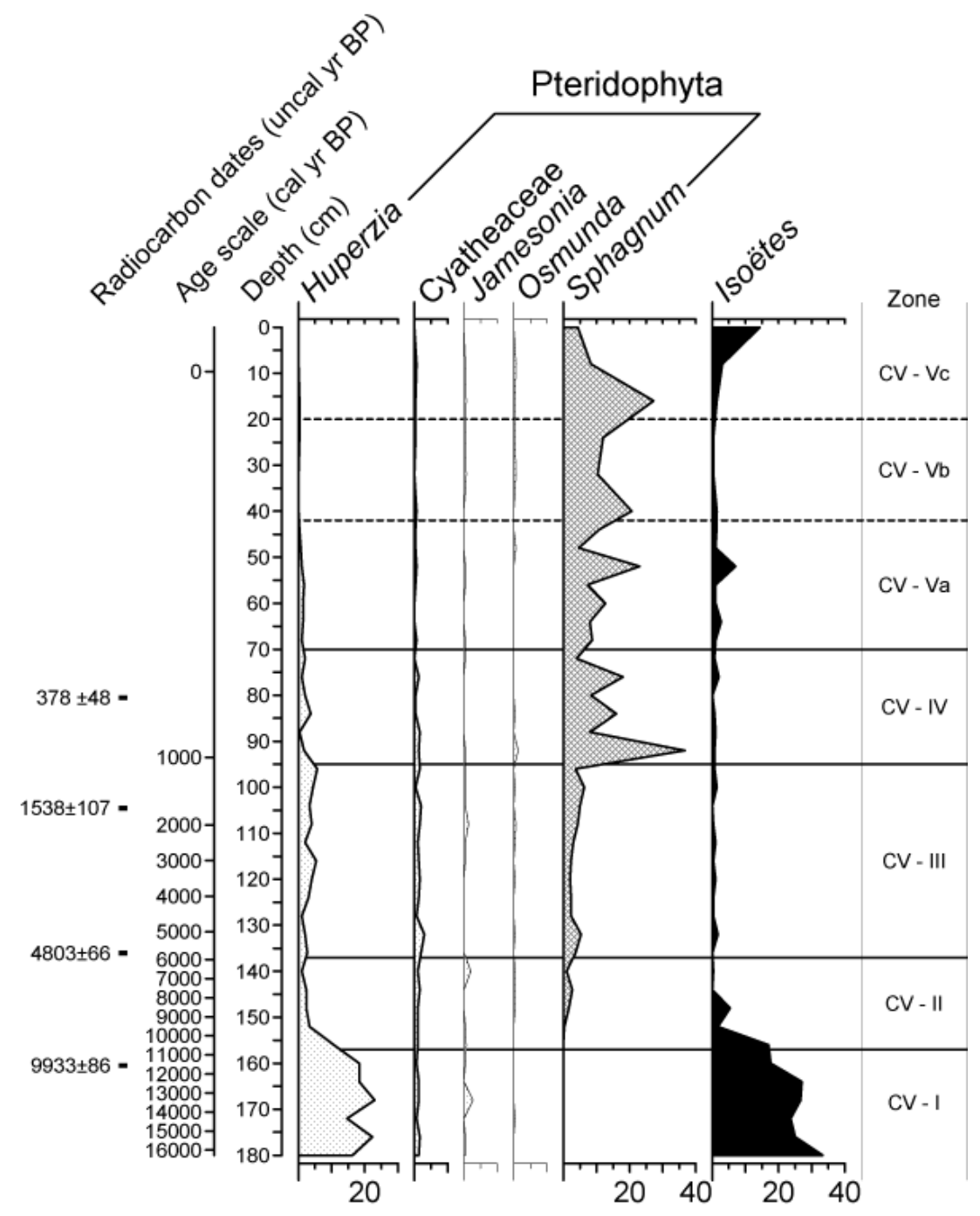




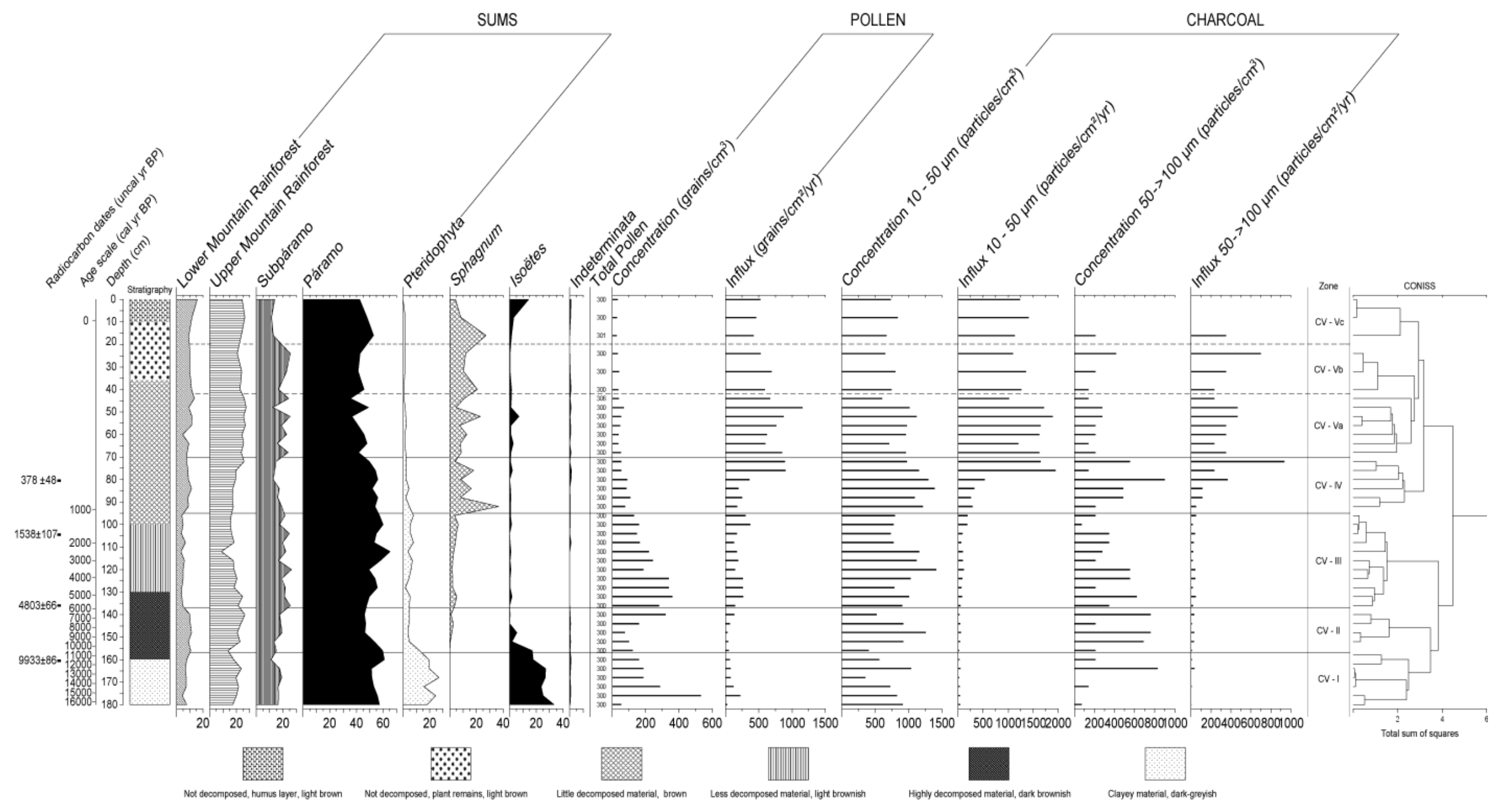




\subsubsection{Anteojos valley complete record percentage diagram}

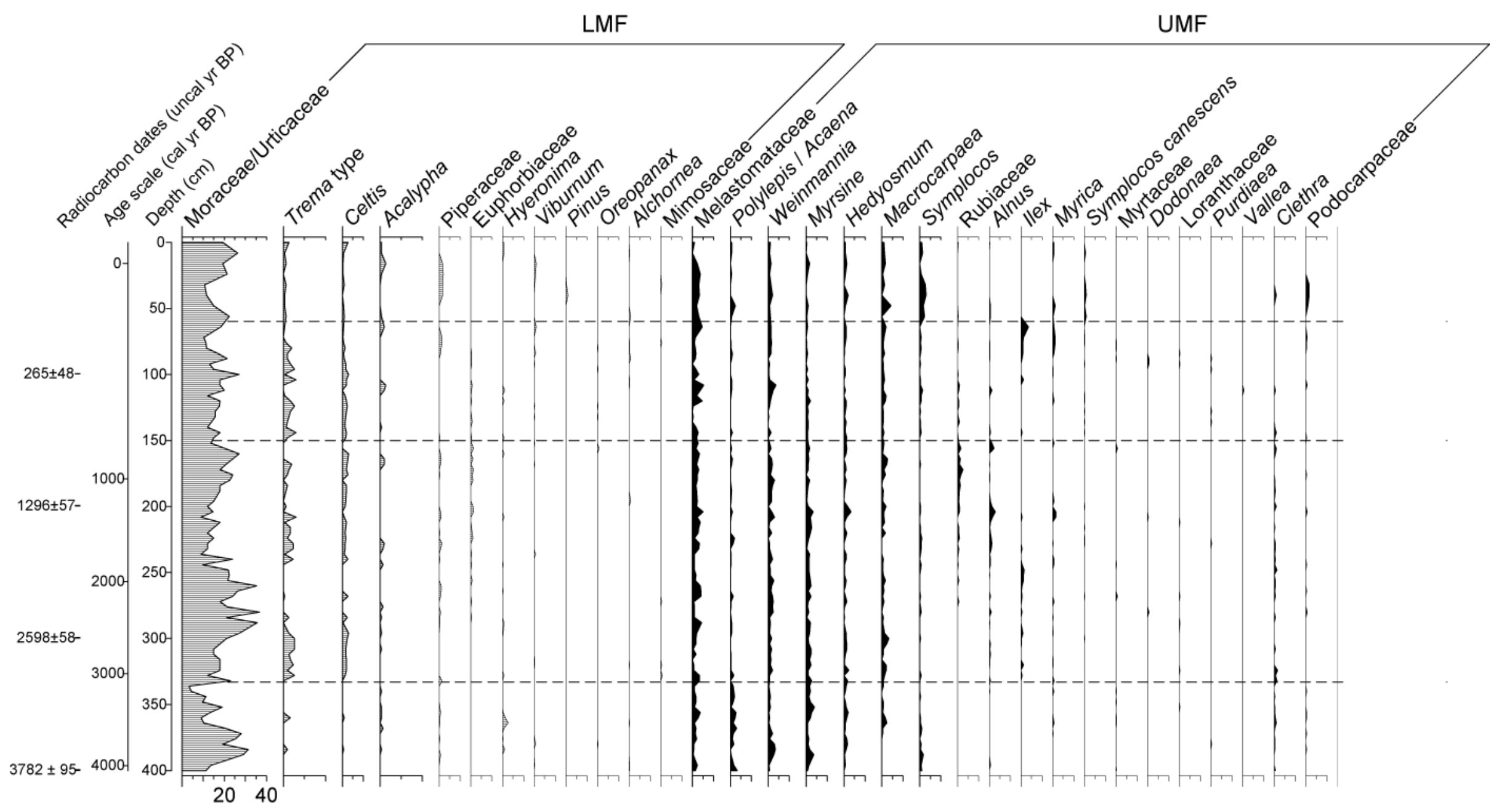


Páramo

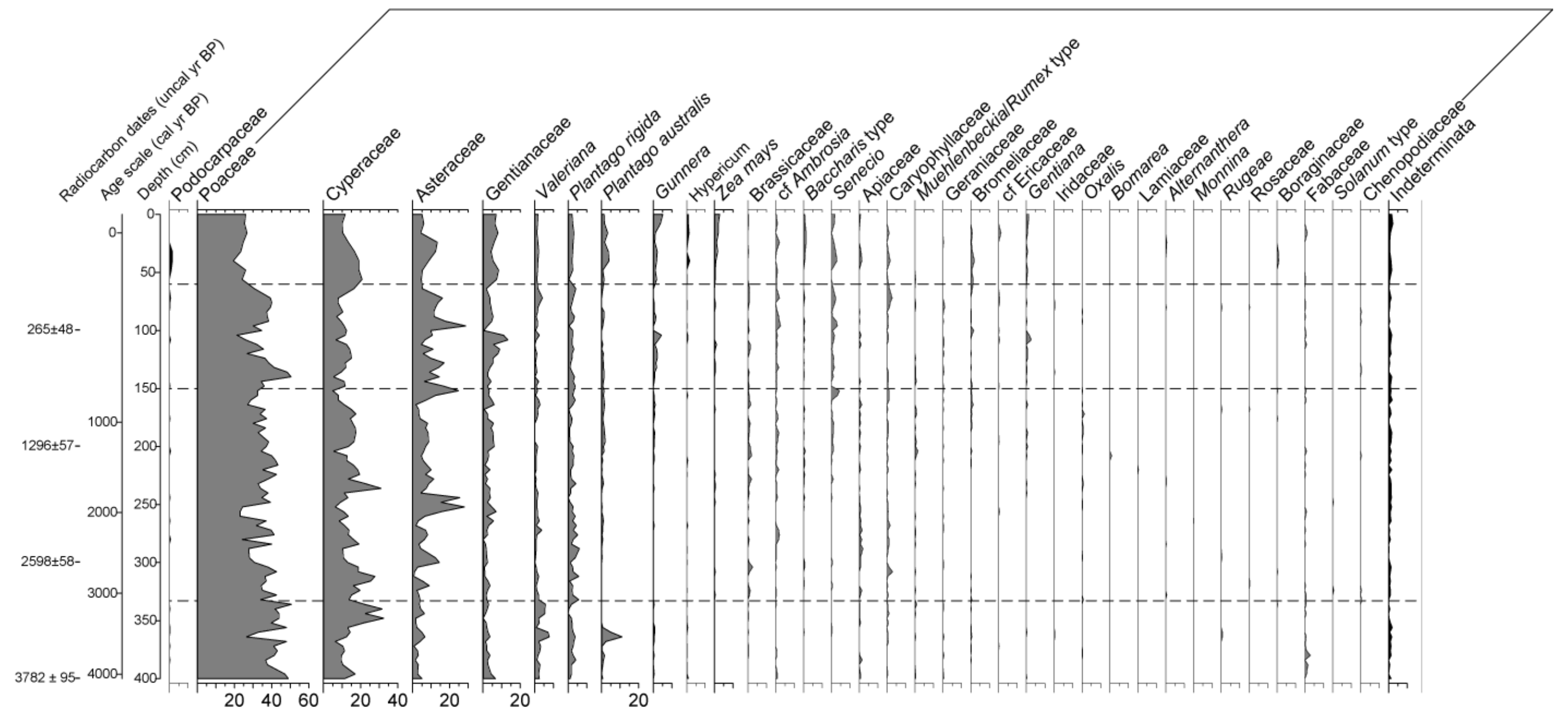




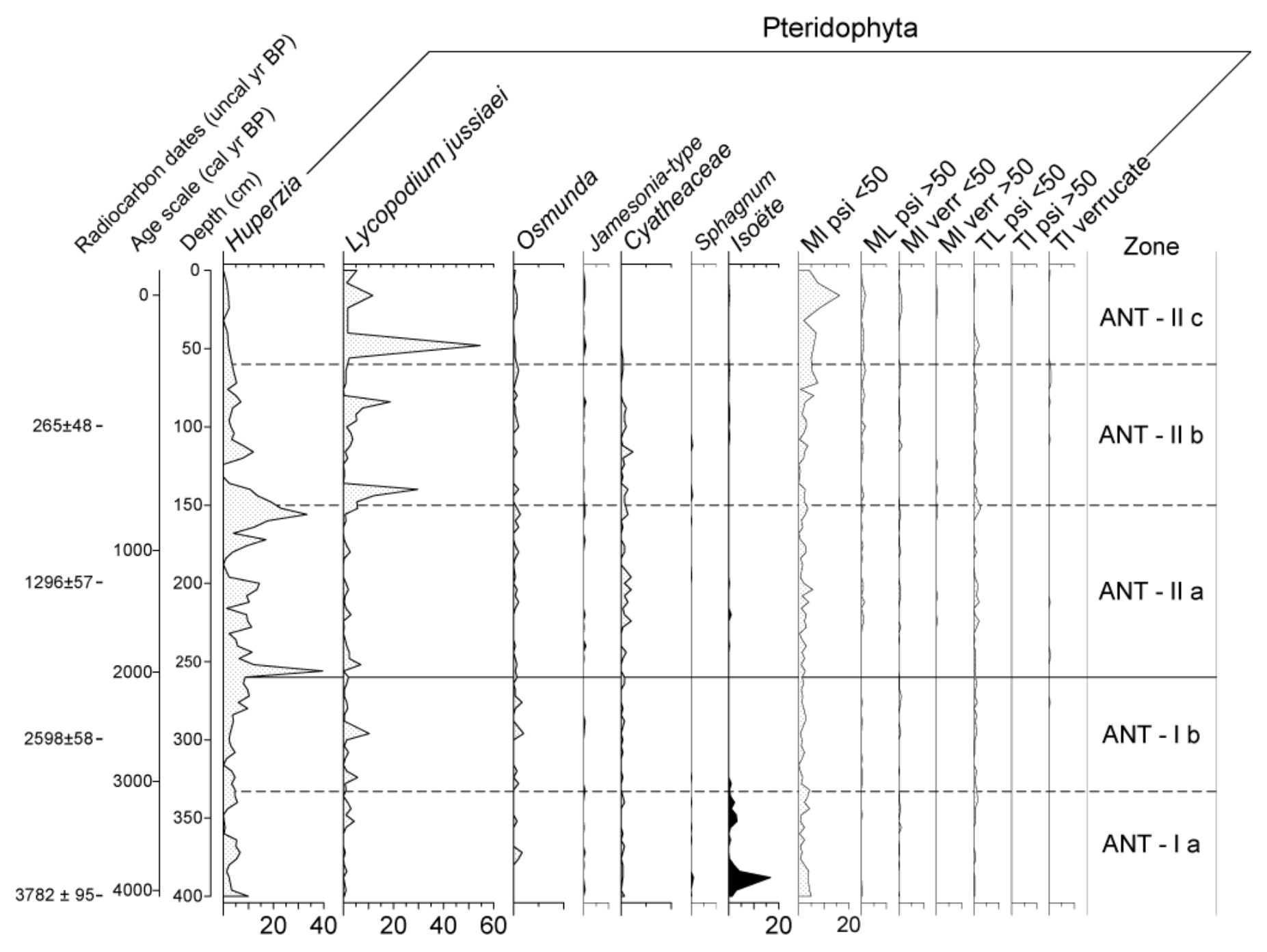


